Florida International University FIU Digital Commons

5-11-2018

\title{
Changes in Soil Microbial Functioning in Coastal Wetlands Exposed to Environmental Stressors and Subsidies
}

Shelby M. Servais

Florida International University, sserv005@fiu.edu

DOI: 10.25148 /etd.FIDC006596

Follow this and additional works at: https://digitalcommons.fiu.edu/etd

Part of the Biogeochemistry Commons, Environmental Microbiology and Microbial Ecology Commons, Fresh Water Studies Commons, Soil Science Commons, and the Terrestrial and Aquatic Ecology Commons

\section{Recommended Citation}

Servais, Shelby M., "Changes in Soil Microbial Functioning in Coastal Wetlands Exposed to Environmental Stressors and Subsidies" (2018). FIU Electronic Theses and Dissertations. 3821.

https://digitalcommons.fiu.edu/etd/3821 


\title{
FLORIDA INTERNATIONAL UNIVERSITY
}

Miami, Florida

\section{CHANGES IN SOIL MICROBIAL FUNCTIONING IN COASTAL WETLANDS EXPOSED TO ENVIRONMENTAL SUBSIDIES AND STRESSORS}

\author{
A dissertation submitted in partial fulfillment of \\ the requirements for the degree of \\ DOCTOR OF PHILOSOPHY \\ in \\ BIOLOGY
}

by

Shelby Servais 
To: Dean Michael R. Heithaus

College of Arts, Sciences and Education

This dissertation, written by Shelby Servais, and entitled Changes in Soil Microbial Functioning in Coastal Wetlands Exposed to Environmental Subsidies and Stressors, having been approved in respect to style and intellectual content, is referred to you for judgment.

We have read this dissertation and recommend that it be approved.

\begin{tabular}{rr}
\hline Rudolf Jaffé \\
\hline Evelyn Gaiser \\
\hline DeEtta Mills \\
\hline Lydia Zeglin \\
\hline John Kominoski, Major Professor
\end{tabular}

Date of Defense: May 11, 2018

The dissertation of Shelby Servais is approved.

Dean Michael R. Heithaus

College of Arts, Sciences and Education

Andrés G. Gil

Vice President for Research and Economic Development and Dean of the University Graduate School

Florida International University, 2018 
(C) Copyright 2018 by Shelby Servais

All rights reserved. 


\section{DEDICATION}

I dedicate this dissertation to my parents, David and Theresa Servais, whose support was essential to the completion of this work. 


\section{ACKNOWLEDGMENTS}

I thank my major advisor, Dr. John Kominoski, for his endless support and expertise. John challenged me to put forth my best work and I could not have succeeded without his mentorship. My committee members, Dr. DeEtta Mills, Dr. Evelyn Gaiser, Dr. Rudolf Jaffé, and Dr. Lydia Zeglin, were invaluable contributors to this dissertation and to my development as a scientist. This dissertation represents collaborative research projects that involved many collaborators whom I thank: Dr. Carlos Coronado, Dr. Tiffany Troxler, Dr. Fred Sklar, and Dr. Steve Davis.

I am extremely grateful towards the undergraduate students I had the privilege of mentoring, particularly Julio Pachón, Kristina Morales, Diana Segrera, Marco Fernandez, and Gabriel Cabral. I thank the entire Florida Coastal Everglades Long Term Ecological Research community and Florida International University Biology Graduate Student Association, especially Sean Charles, Benjamin Wilson, Matthew Smith, Dr. Dong Yoon

Lee, Daniel Virden, Nicholas Schulte, and Emily Brantner. Finally, I thank my family for their support along the way. I could not have done this without encouragement from Theresa, David, Mallory, Edgar, and Grey.

This dissertation was funded by the Florida Sea Grant R/C-S-56 and the Florida Coastal Everglades Long Term Ecological Research Program (NSF DEB 1237517). Writing of this dissertation was financially supported in part through a Florida International University Graduate School Dissertation Year Fellowship. 


\title{
ABSTRACT OF THE DISSERTATION \\ CHANGES IN SOIL MICROBIAL FUNCTIONING IN COASTAL WETLANDS EXPOSED TO ENVIRONMENTAL SUBSIDIES AND STRESSORS
}

\author{
by
}

Shelby Servais

Florida International University, 2018

Miami, Florida

\section{Professor John Kominoski, Major Professor}

Environmental perturbations are ubiquitous features of ecosystems and shape ecological structure and function. Climate change will alter the intensity and frequency of disturbances and expose ecosystems to novel combinations of useful inputs (subsidies) and harmful inputs (stressors). Coastal wetlands are particularly vulnerable to changing environmental conditions and are increasingly exposed to effects of interacting subsidies and stressors. In particular, the Florida Coastal Everglades, which has experienced accelerated change associated with the history of water management practices, is vulnerable to new disturbances associated with climate change. The low-lying Florida Everglades faces multiple disturbances from storm surge, nutrient enrichment, and sealevel rise which will influence its responses to future environmental perturbations. Microbial communities are often used to characterize environmental change because microbes have a high surface area to volume ratio, permeable membrane, and quick turnover rates. Therefore, assessing how microbial function changes can provide insights into how subsidies and stressors interact to alter biogeochemical cycles. I tested how nutrient enrichment can alter ecosystem responses to stress and found that it did not 
promote recovery in mangrove plants. I examined how long-term exposure to salinity and phosphorus (the limiting nutrient in the Everglades) affected microbial enzyme activity and found that salinity alone acts as a suppressor of enzyme activity but phosphorus addition can mitigate salinity stress in sawgrass soil. I tested how pulses of salinity can affect microbially-mediated breakdown of organic material and found that the microbial community was functionally redundant and unaffected by saltwater pulses; however, microbial activity was consistently lower in the brackish marsh compared to the freshwater marsh. I investigated how gradients of salinity and phosphorus affect freshwater and brackish soils and found that prior exposure to saltwater intrusion dictates changes in microbial function and soil composition. Across these experiments, I found that environmental perturbations alter microbial-mediated processing of nutrients and carbon, and legacies of previous disturbances influence the microbial response to new disturbance regimes. 
TABLE OF CONTENTS

CHAPTER

PAGE

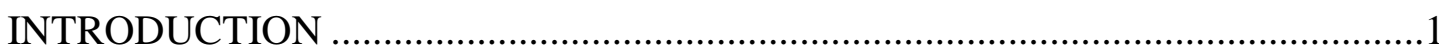

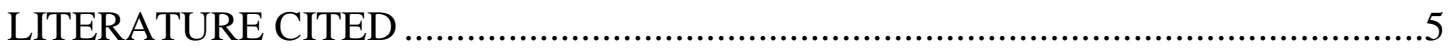

I. INTERACTIVE EFFECTS OF DEFOLIATION AND PHOSPHORUS ENRICHMENT ON BIOGEOCHEMICAL CYCLING IN EXPERIMENTAL

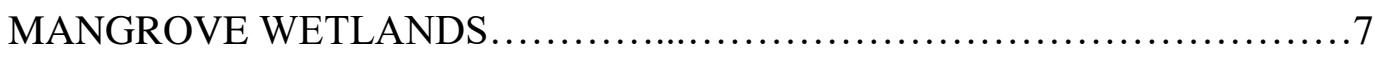

ABSTRACT

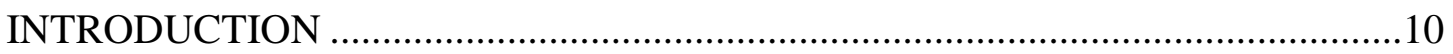

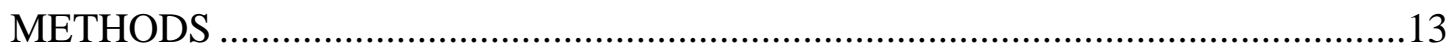

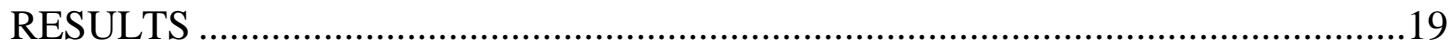

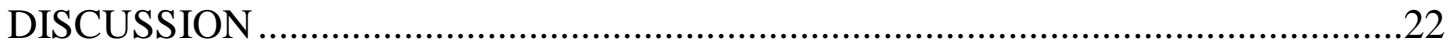

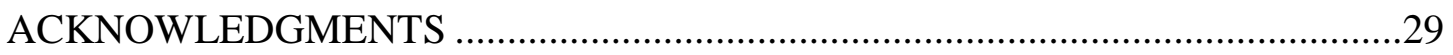

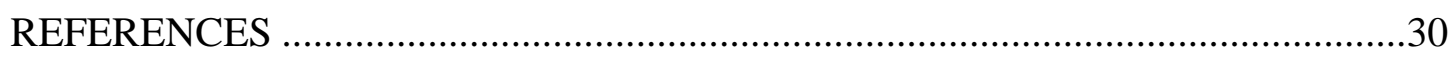

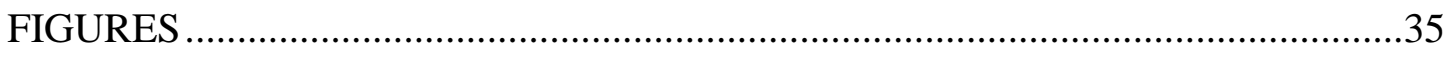

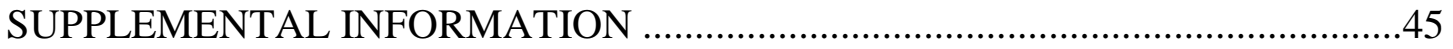

II. QUANTIFYING MICROBIALLY-MEDIATED SOIL CARBON LOSS FROM SALTWATER INTRUSION INTO FRESHWATER WETLANDS: EXPERIMENTAL TESTS OF ELEVATED SALINITY AND

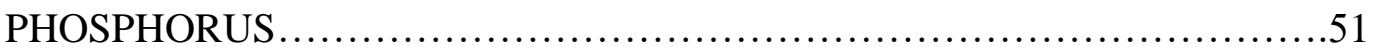

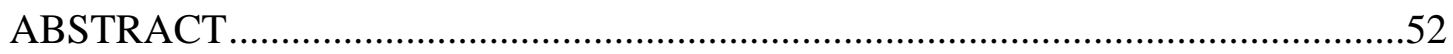

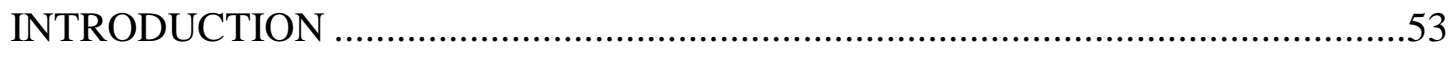

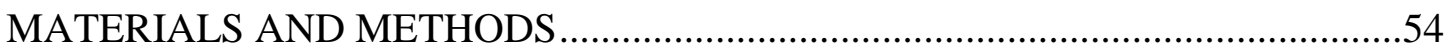

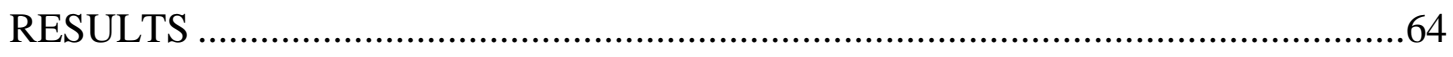

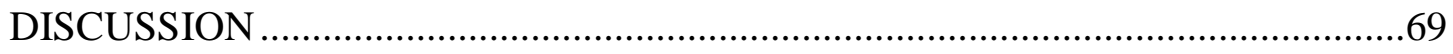

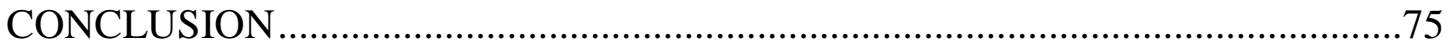

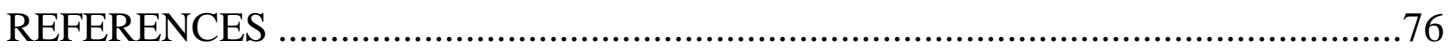

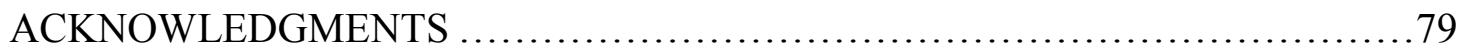

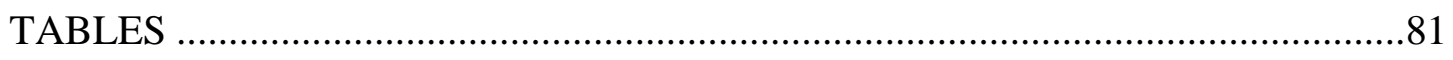

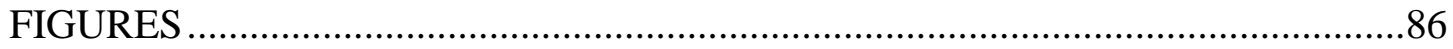

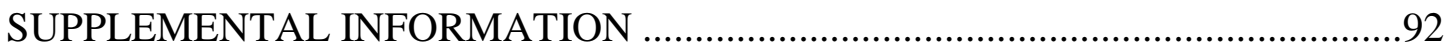

III. EFFECTS OF EXPERIMENTAL SALTWATER PULSES IN COASTAL WETLANDS QUANTIFYING CHANGES IN MICROBIALLYMEDIATED ORGANIC MATTER BREAKDOWN $\ldots \ldots \ldots \ldots \ldots \ldots \ldots \ldots . . . \ldots 9$

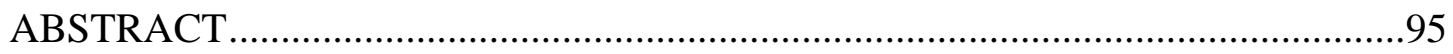

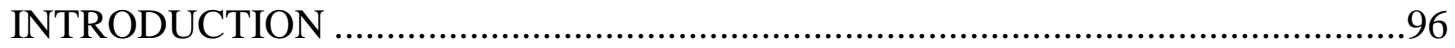

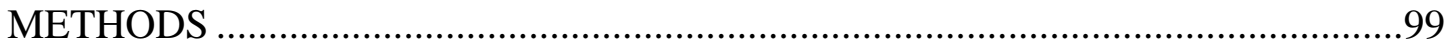




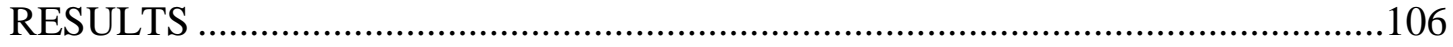

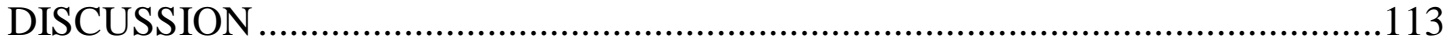

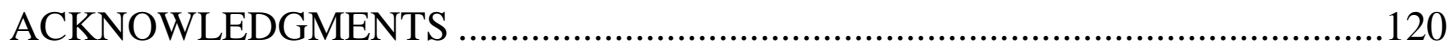

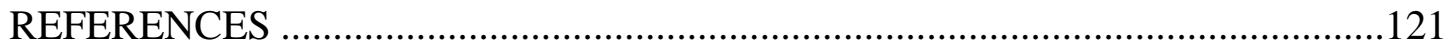

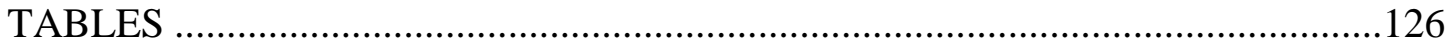

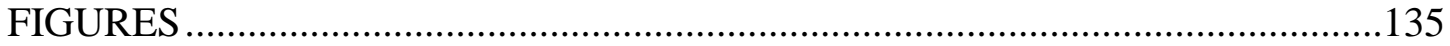

IV. LEGACIES OF EXPOSURE TO SALTWATER DRIVE DIFFERENTIAL SOIL MICROBIAL RESPONSES TO SALINITY AND PHOSPHORUS......144

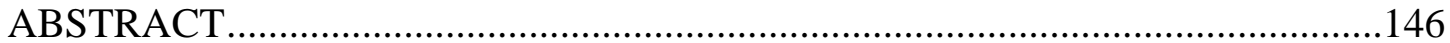

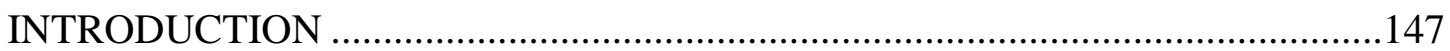

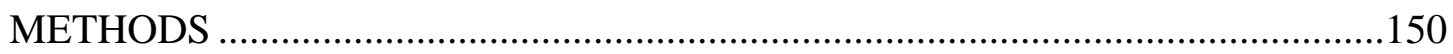

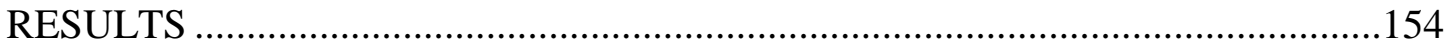

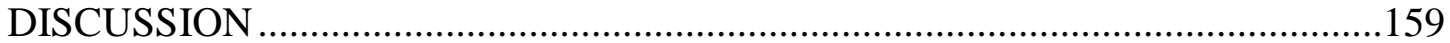

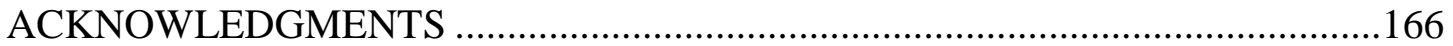

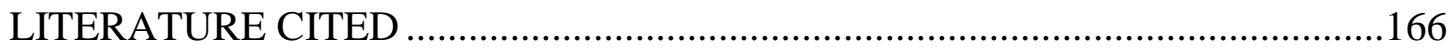

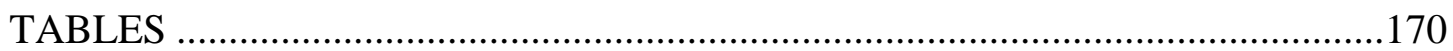

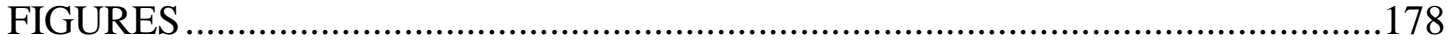

SUPPLEMENTAL INFORMATION ……………….......................................184

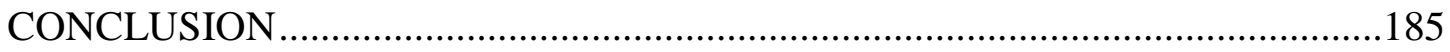

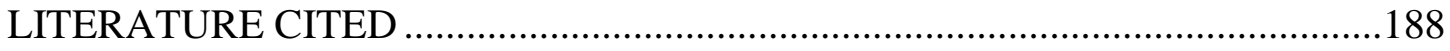

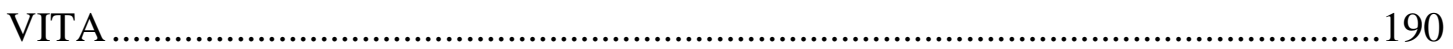




\section{CHAPTER II}

1 Enzymes analyzed, corresponding Enzyme commission number (EC), substrate used in assay, enzyme function, and the predicted response to

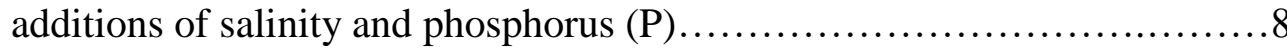

2 Average ( \pm 1 standard error) delta surface water constituents between initial and the 57-d collection, 57-d and 392-d collection, and 392-d and 741-d collection. Units for total organic carbon (TOC), total nitrogen (TN), total phosphorus (TP), dissolved organic C (DOC), nitrate $\left(\mathrm{NO}_{3}{ }^{-}\right)$, nitrite $\left(\mathrm{NO}_{2}{ }^{-}\right)$, dissolved inorganic nitrogen (DIN), ammonium $\left(\mathrm{NH}_{4}{ }^{+}\right)$,

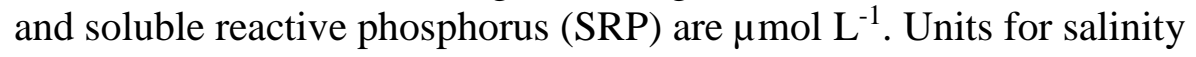
are parts per thousand. Positive delta values represent net increases in the constituent while negative values represent net decreases in the constituent. Nitrate $\left(\mathrm{NO}_{3}{ }^{-}\right)$was below the detection limit (BDL) at 741-d and therefore no delta is reported. Data were analyzed using a two-way ANOVA. Significant effects and interaction terms are reported in the last column. "NS" indicates not significant $(\mathrm{P}>0.05)$. * indicates $\mathrm{P}>0.05$ and $* *$ indicates $\mathrm{P}<0.005$.

3 Average ( \pm 1 standard error) delta porewater constituents between initial and the 57-d collection, 57-d and 392-d collection, and 392-d and 741-d collection. Units for total organic carbon (TOC), total nitrogen (TN), total phosphorus (TP), dissolved organic $\mathrm{C}(\mathrm{DOC})$, nitrate $\left(\mathrm{NO}_{3}{ }^{-}\right)$, nitrite $\left(\mathrm{NO}_{2}{ }^{-}\right)$, dissolved inorganic nitrogen (DIN), ammonium $\left(\mathrm{NH}_{4}{ }^{+}\right)$, and

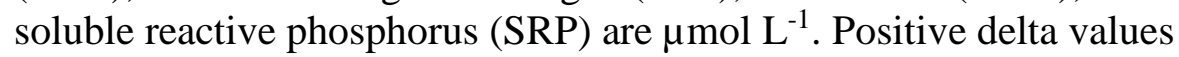
represent net increases in the constituent while negative values represent net decreases in the constituent. Nitrate $\left(\mathrm{NO}_{3}{ }^{-}\right)$was below the detection limit (BDL) at 741-d and therefore no delta is reported. Porewater $\mathrm{pH}$ was not recorded at 57-d, therefore, delta porewater $\mathrm{pH}$ is not reported for 57 and 392-d. Data were analyzed using a two-way ANOVA. Significant effects and interaction terms are reported in the last column. "NS" indicates $P>0.05$ and $* *$ indicates $P>0.005$.

4 Soil \% organic ash free dry mass carbon $(\mathrm{C})$, nitrogen $(\mathrm{N})$, and phosphorus $(\mathrm{P})$ for the four treatments: fresh, fresh $+\mathrm{P}$, salt, salt $+\mathrm{P}$. Soil elemental composition was measured at 57-d for surficial soil, and at 392 and 741-d at two depths $(0-7.5$ and $7.5-15 \mathrm{~cm})$ Treatments were compared using a two-way ANOVA. P-values less than 0.05 were considered significant. Values are reported as percentages $( \pm$ standard error) 
$5 \quad$ Summarized responses to salinity and phosphorus (P) exposure at 57, 392 and 741 days. Data is broken up into two depth profiles for each parameter with the surface water/soil response above the porewater/deeper soil response. Responses are grouped into four categories: suppressed $(\downarrow)$, enhanced $(\uparrow)$, no effect (NS), and interaction $(\leftrightarrow)$. Black spaces indicate that data is absent for that parameter.

Response variables listed are surface water total organic carbon (TOC), dissolved organic $\mathrm{C}$ (DOC), ammonium $\left(\mathrm{NH}_{4}{ }^{+}\right)$, soluble reactive $\mathrm{P}$ (SRP), $\beta$-1,4-glucosidase, $\beta$-1,4-cellobiosidase, soil respiration, microbial biomass, and root breakdown

\section{CHAPTER III}

1 Average $( \pm 1 \mathrm{SE})$ of porewater salinity, $\mathrm{pH}$, alkalinity, dissolved organic carbon (DOC), total dissolved nitrogen (TDN), ammonium $\left(\mathrm{NH}_{4}{ }^{+}\right)$, soluble reactive phosphorus (SRP), total dissolved phosphorus (TDP), sulfate $\left(\mathrm{SO}_{4}{ }^{2-}\right)$, sulfide $\left(\mathrm{HS}^{-}\right)$temperature, and soil redox potential from the brackish and freshwater sites over the two-year duration of the study. Porewater samples were taken at $15-\mathrm{cm}$ depth from the ambient water (control) and saltwater (treatment) addition plots. Salinity is reported in ppt. Alkalinity, DOC, TDN, $\mathrm{NH}_{4}^{+}$, and $\mathrm{SO}_{4}{ }^{-2}$ are $\mathrm{mg} \mathrm{L}^{-1}$. Soluble reactive $\mathrm{P}$, TDP, and $\mathrm{HS}^{-}$are $\mu \mathrm{mol} \mathrm{L}$. Temperature is reported in ${ }^{\circ} \mathrm{C}$. Soil redox is reported in $\mathrm{mV}$. Controls and saltwater treatments were compared for each constituent using a Welch's t-test. Significant differences $(\alpha=0.05)$

are bolded

$2 \quad$ Average ( \pm standard deviation) root breakdown rates $\left(k \mathrm{~d}^{-1}\right)$ at 30 and 740-d for both freshwater and brackish sites. Saltwater treatment $k$ and control $k$ were compared using a Welch two-sample $t$-test at each time point and for both E. cellulosa and $C$. jamaicense. Significant differences were determined using $\alpha=0.05$

3 Full statistical results from a two-way repeated measures ANOVA proportion ash-free dry mass (AFDM) remaining of root litter and percent $(\%)$ carbon $(\mathrm{C})$, nitrogen $(\mathrm{N})$, and phosphorus $(\mathrm{P}), \mathrm{C}: \mathrm{N}, \mathrm{C}: \mathrm{P}$, and $\mathrm{N}: \mathrm{P}$ molar ratios of root litter from the freshwater site $(0-10,10-20,20-30$ $\mathrm{cm})$ given treatment, species, and date. Significant $(\alpha=0.05)$ results in bold. Data presented as $F$ (numerator degrees of freedom, denominator degrees of freedom) $=F$ value, $P=P$ value

4 Table 4. Full statistical results from a two-way repeated measures ANOVA for proportion ash-free dry mass (AFDM) remaining of root litter and percent $(\%)$ carbon $(\mathrm{C})$, nitrogen $(\mathrm{N})$, and phosphorus $(\mathrm{P}), \mathrm{C}: \mathrm{N}$, $\mathrm{C}: \mathrm{P}$, and $\mathrm{N}: \mathrm{P}$ molar ratios of root litter from the brackish site $(0-10,10-$ $20,20-30 \mathrm{~cm})$ given treatment and date. Significant $(\alpha=0.05)$ results in bold. Data presented as $F$ (numerator degrees of freedom, denominator 
degrees of freedom $)=F$ value, $P=P$ value

$5 \quad$ Full statistical results from a two-way repeated measures ANOVA for extracellular enzyme potential from the freshwater sites measured at three depths $(0-10,10-20,20-30 \mathrm{~cm})$ given treatment, species, and date. Significant $(\alpha=0.05)$ results in bold. Data presented as F(numerator degrees of freedom, denominator degrees of freedom $)=F$ value, $P=\mathrm{P}$ value.

$6 \quad$ Full statistical results from a two-way repeated measures ANOVA for extracellular enzyme potential from the brackish sites measured at three depths $(0-10,10-20,20-30 \mathrm{~cm})$ given treatment and date. Significant $(\alpha=$ 0.05 ) results in bold. Data presented as $\mathrm{F}$ (numerator degrees of freedom, denominator degrees of freedom) $=F$ value, $P=\mathrm{P}$ value

7 Average ( \pm standard error) extracellular enzyme activities $\left(\mu \mathrm{mol} \mathrm{g}^{-1} \mathrm{~h}^{-1}\right)$

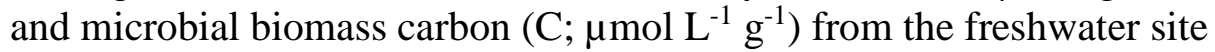
measured on bulk soil collected after 2 years of saltwater manipulations. Soil enzyme activities were measured at three depths $(0-10,10-20$, and $20-30 \mathrm{~cm}$ ) and compared between control chambers and saltwater treatment chambers using a Welch's two-sample $t$-test and an $\alpha=0.05$. Significant differences are bolded

8 Average ( \pm standard error) extracellular enzyme activities $\left(\mu \mathrm{mol} \mathrm{g}^{-1} \mathrm{~h}^{-1}\right)$ and microbial biomass carbon $\left(\mathrm{C} ; \mu \mathrm{mol} \mathrm{L}^{-1} \mathrm{~g}^{-1}\right)$ from the brackish site measured on bulk soil collected after 2 years of saltwater manipulations. Soil enzyme activities were measured at three depths $(0-10,10-20$, and $20-30 \mathrm{~cm}$ ) and compared between control chambers and saltwater treatment chambers using a Welch's two-sample $t$-test and an $\alpha=0.05$. Significant differences are bolded

$9 \quad$ Average ( \pm standard error) percent $(\%)$ carbon $(\mathrm{C})$, phosphorus $(\mathrm{P})$, and nitrogen $(\mathrm{N})$ in bulk soil from the freshwater and brackish sites collected after 2 years of pulsed saltwater additions. Percent $\mathrm{C}, \mathrm{N}$, and $\mathrm{P}$ were measured at three depths $(0-10,10-20$, and 20-30 cm) and compared between control chambers and saltwater treatment chambers using a Welch's two-sample $t$-test and an $\alpha=0.05$. Significant differences are bolded....

\section{CHAPTER IV}

1 Linear fixed-effects models and model weights comparing saltwater (salt), phosphorus (P), week, and soil type and their interactions with dissolved constituents within the water of the incubation chambers. Models with $\triangle \mathrm{AIC}_{\mathrm{c}} \leq 2$ are considered equivalent. 
2 Linear fixed-effects models and model weights comparing saltwater (salt), phosphorus (P), week, and soil type and their interactions on soil elemental composition and stoichiometry. Models with $\Delta \mathrm{AIC}_{\mathrm{c}} \leq 2$ are considered equivalent

3 Linear fixed-effects models and model weights comparing saltwater (salt), phosphorus (P), week, and soil type and their interactions with extracellular enzymes. Models with $\Delta \mathrm{AIC}_{\mathrm{c}} \leq 2$ are considered equivalent.

$4 \quad$ Linear fixed-effects models and model weights comparing saltwater (salt), phosphorus (P), week, and soil type and their interactions on microbial biomass carbon and soil respiration rate. Models with $\Delta \mathrm{AIC}_{\mathrm{c}} \leq$ 2 are considered equivalent.

5 Dissolved water constituents sampled from the freshwater soil incubation chambers after five weeks at different levels of added salinity (salt) and phosphorus $(\mathrm{P})$ concentrations (subscripted numbers corresponded to ppt added salinity and $\mu \mathrm{g} \mathrm{L}^{-1}$ added $\left.\mathrm{P}\right)$. Dissolved inorganic nitrogen $(\mathrm{N}+\mathrm{N})$, ammonium $\left(\mathrm{NH}_{4}{ }^{+}\right.$), soluble reactive $\mathrm{P}$ (SRP), and dissolved organic carbon (DOC) are reported in $\mu \mathrm{g} \mathrm{L}^{-1}$

6 Dissolved water constituents sampled from the brackish soil incubation chambers after five weeks at different levels of added salinity (salt) and phosphorus $(\mathrm{P})$ concentrations (subscripted numbers corresponded to ppt added salinity and $\mu \mathrm{g} \mathrm{L}^{-1}$ added $\left.\mathrm{P}\right)$. Dissolved inorganic nitrogen $(\mathrm{N}+\mathrm{N})$, ammonium $\left(\mathrm{NH}_{4}^{+}\right)$, soluble reactive $\mathrm{P}$ (SRP), and dissolved organic carbon (DOC) are reported in $\mu \mathrm{g} \mathrm{\textrm {L } ^ { - 1 }}$

7 Elemental composition and stoichiometry of freshwater soils after five weeks at different treatment levels of added salinity (salt) and phosphorus (P) concentrations (subscripted numbers corresponded to ppt added

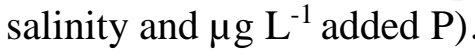

$8 \quad$ Elemental composition and stoichiometry of brackish soils after five weeks at different treatment levels of added salinity (salt) and phosphorus (P) concentrations (subscripted numbers corresponded to ppt added

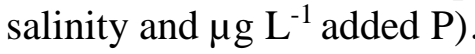




\section{CHAPTER I}

1 Diagram of the outdoor experimental wetlands and mangrove-peat monolith structure. Six experimental wetland mesocosms contained four mangrove-peat monoliths each. Each mesocosm was designated as phosphorus added $(+\mathrm{P})$ or no phosphorus added (-P). Within each mesocosm, mangrove-peat monoliths were designated as defoliated (-L) or non-defoliated $(+\mathrm{L})$. Each mangrove-Peat monolith was contained in a $25 \times 28 \mathrm{~cm}$ perforated bucket equipped with a porewater sipper, $10 \mathrm{~cm}$ diameter collar for $\mathrm{CO}_{2}$ soil efflux measurements, diffusers that were either empty or contained granular orthophosphate in the $+\mathrm{P}$ treatments, and root and leaf decomposition material.

2 Final leaf count (a) and delta leaf count (b) for the four treatments control, leaves removed (-L), phosphorus addition $(+\mathrm{P})$, and leaves removed and phosphorus addition $(+\mathrm{P} /-\mathrm{L})$. Final leaf count (a) was determined by counting the total number of live leaves present on each mangrove plant on the last day of the experiment. Delta leaf count (b) was determined by subtracting the number of leaves after the defoliation treatment was administered from the final leaf count. Treatments were compared using an ANOVA followed by a Tukey HSD for comparison. $\mathrm{P}$-values less than 0.05 were considered significant..

3 Final aboveground leaf biomass (a), final aboveground woody biomass (b), and final belowground coarse woody biomass (c) for the four treatments control, leaves removed $(-\mathrm{L})$, phosphorus addition $(+\mathrm{P})$, and leaves removed and phosphorus addition $(+\mathrm{P} /-\mathrm{L})$. Biomass is reported as ash-free dry mass (AFDM). Treatments were compared using an ANOVA followed by a Tukey HSD for comparison. P-values less than 0.05 were considered significant.

$4 \quad$ Final leaf (a) and root (b) live biomass \% phosphorus (P) for the four treatments control, leaves removed $(-\mathrm{L}), \mathrm{P}$ addition $(+\mathrm{P})$, and leaves removed and $\mathrm{P}$ addition (+P/-L). Treatments were compared using an ANOVA followed by a Tukey HSD for comparison. P-values less than 0.05 were considered significant.

5 Decomposing leaf (a) and root (b) breakdown rates $\left(\mathrm{k} \mathrm{d}^{-1}\right)$ for the four treatments control, leaves removed $(-\mathrm{L})$, phosphorus addition $(+\mathrm{P} /-\mathrm{L})$, and leaves removed and phosphorus addition $(+\mathrm{P} /-\mathrm{L})$. Treatments were compared using an ANOVA followed by a Tukey HSD for comparison. $\mathrm{P}$-values less than 0.05 were considered significant. 
Weekly daytime soil $\mathrm{CO}_{2}$ efflux $\left(\mathrm{CO}_{2}-\mathrm{C}, \mathrm{mg} \mathrm{C} \mathrm{m}^{-2} \mathrm{~d}^{-1}\right)$ for all for the four treatments control, leaves removed (-L), phosphorus addition $(+\mathrm{P} /-$ $\mathrm{L})$, and leaves removed and phosphorus addition $(+\mathrm{P} /-\mathrm{L})$. Treatments were compared using a repeated measures ANOVA followed by a Tukey HSD for comparison. P-values less than 0.05 were considered significant.

$7 \quad$ Final (a) daytime and (b) nighttime soil $\mathrm{CO}_{2}$ efflux $\left(\mathrm{CO}_{2}-\mathrm{C}, \mathrm{mg} \mathrm{C} \mathrm{m}^{-2} \mathrm{~d}^{-}\right.$

$\left.{ }^{1}\right)$ plotted against the total amount of phosphorus $(\mathrm{g})$ released by diffusion by the end of the 42-d experiment. Phosphorus released was calculated by subtracting the amount of granular orthophosphate remaining in the diffusers at the end of the experiment from the starting amount of orthophosphate. Linear regression (solid line) and 95\% confidence interval (dashed lines) are plotted when significant $(P<0.05)$

\section{CHAPTER II}

1 Microbial extracellular enzyme activities from surficial soils $(0-7.5 \mathrm{~cm})$ after 57 days and from soil at 0-7.5 cm and 7.5-15 cm depths at 392 and 741 days. Enzyme activities (phosphatase, aryl sulfatase, $\beta-1,4-$ glucosidase, and $\beta$-1,4-cellobiosidase) were assayed from experimental mesocosm wetlands exposed to four treatments: freshwater (fresh), freshwater with added phosphorus (fresh $+\mathrm{P}$ ), elevated salinity (salt), and elevated salinity with added phosphorus $($ salt $+\mathrm{P})$. Responses were compared using a two-way ANOVA followed by a Tukey HSD for comparison. P-values less than 0.05 were considered significant. Lower case significance indicators $(a, b)$ are reported within the $0-7.5 \mathrm{~cm}$ depth and uppercase significance indicators $(\mathrm{A}, \mathrm{B})$ are reported within the 7.5$15 \mathrm{~cm}$ depth.

2 Soil respiration rates at (a) 57-d, (b) 392-d, and (c) 741-d. Respiration was measured at 0-7.5 cm samples on all dates and at 7.5-15 cm samples on the 392 and 741-d events. For each date and soil depth the four treatments fresh, fresh $+\mathrm{P}$, salt, salt $+\mathrm{P}$ were compared using a two-way ANOVA followed by a Tukey HSD for comparison. P-values less than 0.05 were considered significant.

3 Soil microbial biomass at (a) 392-d and (b) 741-d. Soil microbial biomass was measured at 0-7.5 cm and 7.5-15 cm samples on the 392 and 741-d events. For each date and soil depth the four treatments fresh, fresh $+\mathrm{P}$, salt, salt $+\mathrm{P}$ were compared using a two-way ANOVA followed by a Tukey HSD for comparison. P-values less than 0.05 were considered significant. Uppercase significance indicators $(A, B)$ are reported within the $7.5-15 \mathrm{~cm}$ depth. 
4 Proportion of mass loss during $356 \mathrm{~d}$ incubation of root litter within soil at 0-7.5 and 7.5-15.0 cm depths. Enzyme activities for phosphatases (b), aryl sulfatase (c), $\beta$-1,4-glucosidase (d), and $\beta$-1,4-cellobiosidase (e) are reported in $\mu \mathrm{mol} \mathrm{g}{ }^{-1} \mathrm{~h}^{-1}$ measured on root litter upon retrieval at 356 days. Enzyme activity (phosphatase, aryl sulfatase, $\beta$-1,4-glucosidase, and $\beta$-1,4-cellobiosidase) were calculated from experimental mesocosm wetlands exposed to four treatments: freshwater (fresh), freshwater with added phosphorus (fresh $+\mathrm{P}$ ), elevated salinity (salt), and elevated salinity with added phosphorus (salt $+\mathrm{P}$ ). Responses were compared using a two-way ANOVA followed by a Tukey HSD for comparison. Pvalues less than 0.05 were considered significant. Lower case significance indicators $(\mathrm{a}, \mathrm{b})$ are reported within the $0-7.5 \mathrm{~cm}$ depth and uppercase significance indicators $(A, B)$ are reported within the $7.5-15 \mathrm{~cm}$ depth.

\section{CHAPTER III}

1 Location of the freshwater (FW) and brackish (BW) sites within Everglades National Park (A). Example of the experimental chambers installed in the marsh (B). Design of the mesh litterbags before deployment in the field. (C)

2 Hypothesized path model describing how salinity affects root litter breakdown rates. Arrows indicate hypothesized causal links between variables. The structured set of linear equations that correspond to each response variable can be described based on the links associated with each variable (e.g., microbial activity salinity + porewater constituents, porewater constituents $\sim$ salinity). We hypothesized that microbial activity mediates effects of salinity on root litter breakdown because of the direct effects of salinity stress on microbial activity and indirectly through changes in concentrations of porewater constituents...

3 Percent ash-free dry mass (AFDM) remaining, \% carbon (C), \% nitrogen $(\mathrm{N})$, and \% phosphorus $(\mathrm{P})$ of root litter material collected from litterbags at the freshwater site from five retrieval dates and three depths $(0-10,10-$ $20,20-30 \mathrm{~cm}$ )

4 Percent ash-free dry mass (AFDM) remaining, \% carbon (C), \% nitrogen $(\mathrm{N})$, and \% phosphorus $(\mathrm{P})$ of root litter material collected from litterbags at the brackish site from five retrieval dates and three depths $(0-10,10-$ $20,20-30 \mathrm{~cm})$

5 Extracellular enzyme activities of phosphatase, arylsulfatase, $\beta$ - $1,4-$ glucosidase, $\beta$-1,4-cellobiosidase, and leucine aminopeptidase measured on the collected litterbag material at the freshwater site. Full statistical results from the repeated measures ANOVA are reported in Table 5.......136 
6 Extracellular enzyme activities of phosphatase, arylsulfatase, $\beta$-1,4glucosidase, $\beta$-1,4-cellobiosidase, and leucine aminopeptidase measured on the collected litterbag material at the brackish site. Full statistical results from the repeated measures ANOVA are reported in Table 6

7 The best-supported model for 30-d litter breakdown $\left(\mathrm{k} \mathrm{d}^{-1}\right)$ for the brackish site. Standardized path coefficients are reported, and the sign of the path coefficient indicates the direction of the correlation between variables. The best-supported model explains $44 \%$ of the variation in litter breakdown rates. Dashed arrows indicate nonsignificant path coefficients $(\mathrm{P}>0.05)$.

\section{CHAPTER IV}

1 The experimental layout of response surface design. Each incubation chamber was assigned to a phosphorus treatment level $(+0,20,40,60$, and $80 \mu \mathrm{g} \mathrm{L}^{-1}$ ) and a salinity treatment level (freshwater: $+0,4,7,12$, and $16 \mathrm{ppt}$; brackish: $+10,14,17,22$, and $26 \mathrm{ppt}$ )

2 Surface contour plots of freshwater and brackish soil phosphatase activity measured on week 2 and 5 at different treatment concentrations of salinity and phosphorus.

3 Surface contour plots of freshwater and brackish soil arylsulfatase activity measured on week 2 and 5 at different treatment concentrations of salinity and phosphorus....

$4 \quad$ Surface contour plots of freshwater and brackish soil respiration rates measured on week 2 and 5 at different treatment concentrations of salinity and phosphorus...

5 Surface contour plots of freshwater and brackish soil microbial biomass $\mathrm{C}$ measured on week 2 and 5 at different treatment concentrations of salinity and phosphorus 


\section{INTRODUCTION}

Environmental perturbations are pervasive features of ecosystems and determine ecological organization and function (White and Jentsch 2001). Ecosystem processes are shaped by the presence and interaction of stressors and subsidies introduced by environmental perturbations (Odum et al. 1979). Environmental perturbations are generalized into two broad categories of usable and toxic inputs. Usable inputs, also considered subsidies, enhance ecosystem function at low levels of exposure but can diminish function at higher levels. Harmful inputs, also referred to as stressors, cause immediate adverse effects on ecosystem function (Odum et al. 1979). Climate change will alter the intensity and frequency of disturbance patterns and expose ecosystems to novel combinations of subsidies and stressors. For example, global climate change is simultaneously exposing coastal wetlands to multiple environmental perturbations that act as both stressors and subsidies (Green et al. 2017).

Coastal wetlands contribute economic, social, and environmental services, but are being transformed at alarming rates as coastal wetlands are exposed to high-energy storms, sea-level rise, eutrophication, and changing land management practices (Barbier et al. 2011). Coastal ecosystems are threatened by multiple and interacting stressors such as storm surges, saltwater intrusion, nutrient pollution, climate change, land and water use change (Green et al. 2017). Exposure to environmental perturbations can affect wetland ecosystem functioning but understanding precisely how multiple stressors interact to elicit changing function is difficult. We currently lack studies that test effects 
of multiple interacting stressors and subsidies, at environmentally relevant concentrations, on microbial wetland function.

Coastal wetlands are biogeochemical hotspots and store disproportionate amounts of carbon (C) relative to their land cover (Nahilk and Fennessy 2016). Carbon and nutrients are the foundation of ecosystems, and both abiotic and biotic environmental factors determine the rate of biogeochemical cycles. Abiotic conditions limit rates of biological processing and microorganisms mediate nutrient cycling and the decomposition of organic matter (Falkowski et al. 2008). After initial chemical leaching, microbial enzyme production is considered the rate-limiting step in the breakdown of organic material. Microorganisms and their changing function can be used to detect environmental perturbations. Assessing changes in soil elemental composition, organic matter breakdown, and extracellular enzyme activity can serve as an indicator of ecological health and give insight into how $\mathrm{C}$ and nutrient cycling will be altered in the future (Sinsabaugh 1994). Microbial functional responses like substrate decomposition, enzyme potential, respiration, and biomass can explain how microorganisms are responding to changing environmental conditions to affect biogeochemical cycles. Understanding causes of microbial functional changes help predict how ecosystem $\mathrm{C}$ and nutrient cycling will change in the future.

Climate change and anthropogenic management practices within the Everglades alter the frequency and intensity of exposure to salinity, phosphorus, and storm surge. The Everglades landscape represents a gradient in freshwater to marine wetlands determined by oligotrophic freshwater flow from Lake Okeechobee and phosphorus-rich marine water infiltration from Florida Bay (Childers 2006). Frequent disturbances and 
rapid climate change confront the Everglades which already has been impacted by management practices (Sklar and Browder 1998). My dissertation research tests the interaction of subsidies and stressors specific to the Everglades landscape to address how different ecosystems will be affected by expected changes in environmental conditions.

I focused on soil microbial functioning as little is known about how the functioning of the soil microbial community in the Florida Coastal Everglades will be affected by changing environmental conditions, or how microorganisms are contributing to observed changes in ecosystem structure and function. Microbial response measures create an overall predictive assessment of the variation in microbial susceptibility and overall stability of Everglades' soils to environmental stressors and subsidies. Despite occurring at a microscopic scale, microbial responses such as the production of extracellular enzymes, have ecosystem-scale effects on $\mathrm{C}$ storage and nutrient cycling (Moorhead and Sinsabaugh 2006). Microbial communities, extracellular enzymes, and the quality of soil organic matter are connected in a successional loop influenced by environmental conditions.

The overarching goal of my dissertation was to assess the interaction of subsidies and stressors across the Everglades landscape from coastal mangroves to freshwater sawgrass marshes. Within each distinct ecosystem, I tested effects of specific stresses and subsidies that are characteristic of each, In the coastal mangrove forests of the Florida Everglades high energy tropical storms and hurricanes are intermittent stress events that have both immediate and long-lasting effects on ecosystem processes (Lugo 2000, 2008). Storms affect mangrove ecosystems through exposure to wind damage, storm surge, and nutrient rich sediment deposition (Barr et al. 2012). In mangrove forests, high-energy 
storms contribute both stresses (wind damage, tree mortality) and subsidies (marine nutrients, allocthonous energy inputs) to coastal ecosystems (Castañeda-Moya et al. 2010). In Chapter I, I investigated how coastal mangroves and their soils respond to perturbations associated with storm surges. I examined the interactive effects of stormdriven stress (plant defoliation) and subsidy (P deposition) on mangroves plants and biogeochemical cycling within mangrove soils.

Further inland the interacting stressors and subsidies are different, but play equally important roles in regulating ecosystem function. Freshwater and brackish marshes in the Everglades are increasingly exposed to saltwater intrusion. The Everglades is particularly vulnerable to saltwater intrusion as see levels are predicted to rise up to $2 \mathrm{~m}$ by 2100 (Haigh et al 2004) and legacies of hydrologic management have reduced historic freshwater flows (Sklar et al. 2005). Saltwater intrusion not only exposes Everglades wetlands to the stress of salinity but also the limiting nutrient, $\mathrm{P}$ (Childers et al. 2006, Flower et al. 2017). Saltwater contains cations that promote the desorption of phosphate that is adsorbed limestone bedrock in the Everglades, consequentially releasing bioavailable P. Therefore, for my remaining chapters, I focus on the interactions of salinity stress and $\mathrm{P}$ subsidies on microbially-mediated biogeochemical cycling within soils.

In Chapter II, I examined how freshwater soil microbial functioning is affected by stressful inputs of salinity and subsidizing inputs of P. In Chapter III, I worked in both a brackish and a freshwater marsh and conducted an in situ experiment to investigate how pulses of salinity alter organic matter decomposition and microbially-mediated biogeochemical cycling. In Chapter IV, I expanded upon chapters II and III, to test 
effects of multiple levels of crossed gradients of salinity (stress input) and P (subsidy input) altered microbially-mediated biogeochemical cycling in both freshwater and brackish soils. Chapter I is formatted to be submitted to Wetlands, Chapter II is formatted to be submitted to Geoderma, and Chapter III is formatted to be submitted to Estuaries and Coasts, Chapter IV is formatted to be submitted to Ecological Applications.

\section{LITERATURE CITED}

Barbier, E.B., Hacker, S.D., Kennedy, C., Koch, E.W., Stier, A.C. and Silliman, B.R., 2011. The value of estuarine and coastal ecosystem services. Ecological Monographs, 81(2), pp.169-193.

Barr, J.G., Engel, V., Smith, T.J. and Fuentes, J.D., 2012. Hurricane disturbance and recovery of energy balance, $\mathrm{CO}_{2}$ fluxes and canopy structure in a mangrove forest of the Florida Everglades. Agricultural and Forest Meteorology, 153, pp.54-66.

Castañeda-Moya, E., Twilley, R.R., Rivera-Monroy, V.H., Zhang, K., Davis, S.E. and Ross, M., 2010. Sediment and nutrient deposition associated with Hurricane Wilma in mangroves of the Florida Coastal Everglades. Estuaries and Coasts, 33(1), pp.45-58.

Childers, D.L., 2006. A synthesis of long-term research by the Florida Coastal Everglades LTER Program. Hydrobiologia, 569(1), pp.531-544.

Falkowski, P.G., Fenchel, T. and Delong, E.F., 2008. The microbial engines that drive Earth's biogeochemical cycles. Science, 320(5879), pp.1034-1039.

Flower, H., Rains, M., Lewis, D., Zhang, J.Z. and Price, R., 2017. Saltwater intrusion as potential driver of phosphorus release from limestone bedrock in a coastal aquifer. Estuarine, Coastal and Shelf Science, 184, pp.166-176.

Green, A.J., Alcorlo, P., Peeters, E.T., Morris, E.P., Espinar, J.L., Bravo-Utrera, M.A., Bustamante, J., Díaz-Delgado, R., Koelmans, A.A., Mateo, R. and Mooij, W.M., 2017. Creating a safe operating space for wetlands in a changing climate. Frontiers in Ecology and the Environment, 15(2), pp.99-107. 
Haigh, I.D., Wahl, T., Rohling, E.J., Price, R.M., Pattiaratchi, C.B., Calafat, F.M. and Dangendorf, S., 2014. Timescales for detecting a significant acceleration in sea level rise. Nature Communications, 5, p.3635.

Lugo, A.E., 2000. Effects and outcomes of Caribbean hurricanes in a climate change scenario. Science of the Total Environment, 262(3), pp.243-251.

Lugo, A.E., 2008. Visible and invisible effects of hurricanes on forest ecosystems: an international review. Austral Ecology, 33(4), pp.368-398.

Odum, E.P., Finn, J.T. and Franz, E.H., 1979. Perturbation theory and the subsidy-stress gradient. Bioscience, 29(6), pp.349-352.

Moorhead, D.L. and Sinsabaugh, R.L., 2006. A theoretical model of litter decay and microbial interaction. Ecological Monographs, 76(2), pp.151-174.

Nahlik, A.M. and Fennessy, M.S., 2016. Carbon storage in US wetlands. Nature Communications, 7, p.13835.

Sinsabaugh, R.S., 1994. Enzymic analysis of microbial pattern and process. Biology and Fertility of Soils, 17(1), pp.69-74.

Sklar, F.H. and Browder, J.A., 1998. Coastal environmental impacts brought about by alterations to freshwater flow in the Gulf of Mexico. Environmental Management, 22(4), pp.547-562.

Sklar, F.H., Chimney, M.J., Newman, S., McCormick, P., Gawlik, D., Miao, S., McVoy, C., Said, W., Newman, J., Coronado, C. and Crozier, G., 2005. The ecologicalsocietal underpinnings of Everglades restoration. Frontiers in Ecology and the Environment, 3(3), pp.161-169.

White, P.S. and Jentsch, A., 2001. The search for generality in studies of disturbance and ecosystem dynamics. In Progress in Botany (pp. 399-450). Springer, Berlin, Heidelberg. 


\section{CHAPTER I}

INTERACTIVE EFFECTS OF DEFOLIATION AND PHOSPHORUS ENRICHMENT ON BIOGEOCHEMICAL CYCLING IN EXPERIMENTAL MANGROVE

WETLANDS 
Title: Interactive effects of defoliation and phosphorus enrichment on biogeochemical cycling in experimental mangrove wetlands

Shelby Servais ${ }^{1 *}$, John S. Kominoski ${ }^{1}$, Stephen E. Davis ${ }^{2}$, Evelyn E. Gaiser ${ }^{1}$, Julio Pachón $^{3}$, Tiffany G. Troxler ${ }^{1}$

${ }^{1}$ Department of Biological Sciences and Southeast Environmental Research Center, Florida International University, Miami, Florida 33199 USA

${ }^{2}$ Everglades Foundation, Palmetto Bay, Florida 33157 USA

${ }^{3}$ Department of Soil and Water Science, University of Florida, Gainesville, Florida 32611 USA

*Email: sserv005@fiu.edu, Phone: (410) 8523720 


\begin{abstract}
High-energy storms frequently re-organize coastal wetlands, but the rate of recovery from storms may vary with resource availability. To understand how limiting resource availability interacts with storm-induced plant stress to influence recovery trajectories, we tested how defoliation associated with tropical storms interacts with nutrient enrichment to affect carbon (C) and nutrient (phosphorus, P) uptake and storage by soils and plants. In outdoor experimental mesocosms, we defoliated red mangrove saplings (Rhizophora mangle), added inorganic P to peat soils, and quantified plant (elemental composition, leaf count, and biomass) and soil (elemental composition, litter breakdown, soil $\mathrm{CO}_{2}$ efflux) responses during a 42-day recovery period. Mangroves regrew all removed leaves and recovered nearly $30 \%$ of defoliated leaf biomass. Mangrove leaf and root $\% \mathrm{P}$ increased by $50 \%$ with added $\mathrm{P}$; however, soil stoichiometry (C: nutrients) did not change. Soil $\mathrm{CO}_{2}$ efflux was reduced by $40 \%$, and root litter breakdown rates were reduced by $30 \%$ with defoliation. Mangroves recovered aboveground biomass and reduced belowground $\mathrm{C}$ losses following defoliation and added $\mathrm{P}$ stimulated plant $\mathrm{P}$ retention and soil $\mathrm{C}$ loss. Mangroves can recover defoliated leaves within six weeks. A reduction in $\mathrm{C}$ mineralization diminishes $\mathrm{C}$ losses, and mangroves quickly incorporate available $\mathrm{P}$ into above and belowground biomass.
\end{abstract}

Key Words: wetland; mesocosms; peat; nutrients; coastal storms; climate change 


\section{INTRODUCTION}

Coastal wetlands are exposed to multiple types of disturbances that influence attributes of ecosystem structure and function that can ultimately affect recovery of function. Resilience is defined as an ecosystem's ability to recover to a persistent state, following a disturbance (Holling 1973; Boesch 1974, White and Jentsch 2001, Johnstone et al. 2016). Therefore, ecosystems with rapid recovery of functions are thought to have resilience. Changes in the patterns of disturbance drivers and increases in acute stressors like nutrient pollution can influence ecosystem recovery following otherwise natural disturbances (Odum et al. 1995). Maintaining C storage is a critical ecosystem function that can be used to measure an ecosystem's capacity for resilience to disturbance (Sistla and Schimel 2012).

High-energy tropical storms and hurricanes are intermittent disturbance events that can affect the structure and function of coastal environments (Michener et al. 1997; Lugo 2000, 2008) through exposure to wind damage, storm surge, and sediment deposition (Smith et al. 1994; Doyle et al. 1995; Deng et al. 2010; Barr et al. 2012). Mangrove forests are considered particularly vulnerable to damage caused by highenergy storms because of their position on the coast (Sherman et al. 2001; Piou et al. 2006). Despite high exposure, mangrove forests can recover quickly following storm disturbance because of key life history traits, such as translocation of above- and belowground nutrient stores, rapid nutrient recycling rates, and quick leaf regrowth that allow mangroves to respond to stressors associated with storms (Alongi 2008; Barr et al. 2012). Mangroves in the Florida Everglades experience a high frequency of tropical storms and hurricanes (Duever et al. 1994; Smith et al. 1994; Krauss et al. 2005; Deng et 
al. 2010). In the 20th century, the Everglades was in the path of several devastating storms: Labor Day Storm (1935), Hurricane Donna (1960), and Hurricane Andrew (1992). High-energy storms contribute both stresses (wind damage, tree mortality) and subsidies (marine nutrients, allocthonous energy inputs) to coastal ecosystems (Castañeda-Moya et al. 2010). Karst-based, Caribbean coastal wetlands, like the Florida Coastal Everglades, are P-limited (Fourqurean et al. 1993; Boyer et al. 1999; Noe et al. 2001) and depend on marine-derived P to support coastal productivity (Chen and Twilley 1999a, 1999b, Childers et al. 2006, Barr et al. 2012). Hurricane Wilma defoliated large areas of coastal mangrove forest and deposited P-rich sediment, altering biogeochemistry by increasing total $\mathrm{P}$ concentrations to $0.19 \mathrm{mg} \mathrm{cm}^{-3}$, which is double the average soil nutrient total P (Castañeda-Moya et al. 2010). As observed from Hurricane Wilma, storms defoliate mangroves while simultaneously subsidizing wetland soils with P-rich marine sediments (Smith et al. 2009). Although mangroves regenerated leaves following Hurricane Wilma, there is evidence that some of the mangroves in the Everglades failed to recover fully (Barr et al. 2012, Danielson et al. 2017). It is not clear how nutrient deposits, associated with the storm contributed to mangrove regeneration. Therefore, it is critical for us to better understand mechanistic differences in plant and soil responses to changes in storm-derived subsidies and stresses.

To test how resource limitation affects recovery from disturbance we investigated plant- and soil-mediated subsidy and stress responses. We manipulated disturbance and nutrient subsidies in outdoor experimental wetland mesocosms containing red mangrove (Rhizophora mangle) saplings. We used mangrove saplings because the effects of hurricane and storm surge on mangrove saplings have not been explicitly tested. As 
mangroves continue to expand into continental interiors and latitudinally with climate change it is important to understand how disturbance will affect new recruits (Comeaux et al. 2012; Bianchi et al. 2013;). We defoliated mangroves, added inorganic $\mathrm{P}$ to soils, and measured changes in plant and soil $\mathrm{C}$ storage and $\mathrm{P}$ uptake as indicators of recovery.

We addressed the following questions: 1) How does simultaneous exposure to a subsidy (P addition) affect mangrove plants and soils exposed to stress (defoliation)? 2) How do plant defoliation and added P interactively modify short-term mangrove plant and soil $\mathrm{C}$ storage and $\mathrm{P}$ uptake? and 3) How do defoliation and $\mathrm{P}$ addition differentially affect above-and below-ground plant and soil responses? We predicted that addition of $\mathrm{P}$ would increase mangrove leaf and root biomass and P content, soil P content, litter breakdown rates, and soil $\mathrm{CO}_{2}$ efflux. We predicted net gains in plant and soil $\mathrm{P}$ and net losses in soil C with the addition of $\mathrm{P}$. We also predicted that defoliation would increase soil $\mathrm{CO}_{2}$ efflux because of increased soil microbial and root respiration. In contrast, we predicted defoliation would lead to decreased litter breakdown rates caused by reduced levels of plant exudates known to make complex recalcitrant organic compound available to soil microbes. We anticipated that the most significant losses in plant $\mathrm{C}$ and leaf number would be attributed to defoliation while the majority of the losses in soil C would be assigned to P addition (Howarth and Fischer 1976; Robinson and Gessner 2000). Finally, we predicted that plants with added $\mathrm{P}$ would recover more quickly and completely after defoliation than those without added $\mathrm{P}$ and that $\mathrm{C}$ storage would be positive with added $\mathrm{P}$ despite defoliation if increases in mangrove plant biomass were more significant than soil C losses (Lovelock et al. 2011). 


\section{METHODS}

\section{Study area and experimental wetland facility}

We collected twenty-four peat cores from a coastal mangrove forest near lower

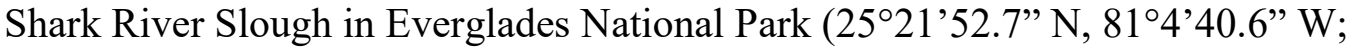

Chambers et al. 2014). We transported soil cores (approximately $25 \mathrm{~cm}$ deep $\times 28 \mathrm{~cm}$ diameter) to the Florida Bay Interagency Science Center Outdoor Mesocosm Facility in Key Largo, FL (255'9.21” N, 80²7'6.9”), following Chambers et al. (2014). We planted a single red mangrove (Rhizophora mangle) propagule in the center of each soil core, and planted saplings grew for two years before the start of our experiment. At the beginning of our study, the mangrove saplings were $56.36 \pm 1.51 \mathrm{~cm}$ tall from the soil surface to the top branch. Mangrove-peat soil monoliths were randomly assigned to and placed in concrete mesocosms $(0.7 \mathrm{~m} \mathrm{D} \times 0.8 \mathrm{~m} \mathrm{~W} \times 2.2 \mathrm{~m} \mathrm{~L})$ containing saltwater from nearby Florida Bay (see below). The composition of the initial soils was as follows 24.9 $\pm 0.9 \% \mathrm{C}, 1.4 \pm 0.1 \% \mathrm{~N}$, and $0.06 \pm 0.00 \% \mathrm{P}$.

\section{Experimental design}

Seawater was pumped from nearby Florida Bay and stored in water holding tanks $\left(7.6 \mathrm{~m}^{3}\right)$, which released water into each concrete mesocosm at a constant flow-through

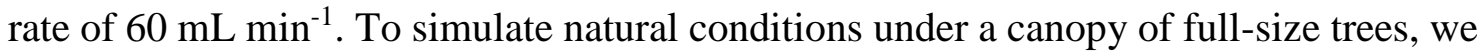
covered mesocosms with nylon mesh shade cloth at the start of the experiment, and they remained shaded for the duration of our study. The shade cloth reduced photosynthetic active radiation by $70 \%$. We measured water levels weekly using a meter stick affixed to each mesocosm to ensure a consistent water level of $27 \mathrm{~cm}$, relative to the bottom of each 
mesocosm, throughout the experiment, ensuring that the soil surface of each mangrove monoliths was submerged. We drained the mangrove-peat monoliths once each week to measure soil $\mathrm{CO}_{2}$ efflux (see below).

We manipulated two factors of added $\mathrm{P}$ and defoliation. Within each concrete mesocosm, four mangrove-peat monoliths were housed in individual 25-L plastic containers $(0.42 \mathrm{~m} \mathrm{D} \times 0.5 \mathrm{~m} \mathrm{~W} \times 0.7 \mathrm{~m} \mathrm{~L}$; Fig. 1). Collectively, we characterized the four treatments as: (i) control, (ii) $-\mathrm{L}$, (iii) $+\mathrm{P}$, (iv) $+\mathrm{P} /$-L for no added $\mathrm{P}$ with leaves (i), no added $\mathrm{P}$ and defoliation (ii), $\mathrm{P}$ addition with leaves (iii), and $\mathrm{P}$ addition/defoliation (iv), respectively. We added $30 \mathrm{~g}$ of granular orthophosphate (Hoffman $®$, Lancaster, New York, USA) to $125-\mu \mathrm{m}$ mesh containers (hereafter diffusers) inserted at $20 \mathrm{~cm}$ within the soil monolith to ensure added P stayed within the soil and was not transported out of the mangrove-peat monolith and to help control the rate of $\mathrm{P}$ release. Inorganic $\mathrm{P}$ diffused over the course of the 42-d experiment. Empty diffusers were added to the -P monoliths. We measured the mass of orthophosphate remaining in diffusers by retrieving all diffusers, rinsing off the residual soil, and drying the remaining orthophosphate. The defoliation treatment consisted of a single event of complete removal of leaves at the start of the experiment. The leaves in the defoliated treated mangroves were removed on day 0 and began the experiment without leaves. We used the leaves removed to measure leaf litter breakdown all treatment conditions (see below). Litter for root breakdown was collected by clipping prop roots that had grown beyond soil monoliths.

A 10-cm diameter polyvinyl chloride (PVC) collar (10 cm height) was inserted in each of the mangrove-peat monoliths and left for the duration of the experiment to place a gas chamber for $\mathrm{CO}_{2}$ efflux measurements. To measure porewater, we installed a sipper 
through the side bucket perforation into the center of each monolith at a depth of $10 \mathrm{~cm}$ from the soil surface.

Experimental measurements were conducted at various intervals throughout $42 \mathrm{~d}$. The timeframe coincided with when all removed leaves from the defoliation treatment fully regenerated and when we expected the majority of added P would have been released from experimental diffusers.

\section{Physicochemical conditions}

We measured water temperature and salinity biweekly $(n=24)$. During the biweekly measurements, we also collected surface water samples (filtered and unfiltered) and filtered pore water samples from each plant-soil monolith $(n=72)$. Unfiltered surface water samples were collected in $60 \mathrm{~mL}$ HDPE sample bottles. Filtered surface water samples were collected in a plastic syringe and filtered onsite through a $0.45-\mu \mathrm{m}$ membrane filter into a $60 \mathrm{~mL}$ HDPE sample bottle. Filtered porewater samples were collected by extracting water from the sipper embedded in each monolith. Then the porewater was filtered using a $0.45 \mu \mathrm{m}$ membrane filter and released into a $60 \mathrm{~mL}$ HDPE sample bottle. All water samples were stored at $-20^{\circ} \mathrm{C}$ until analysis at the Southeast Environmental Research Center, Nutrient Analysis Laboratory. Unfiltered surface water was analyzed for total N (TN), total P (TP), and total organic C (TOC). Filtered porewater and filtered surface water samples were analyzed for dissolved organic $\mathrm{C}$ (DOC), dissolved inorganic nitrogen (DIN, $\mathrm{NO}_{3}{ }^{-}, \mathrm{NO}_{2}{ }^{-}, \mathrm{NH}_{4}{ }^{+}$), and soluble reactive $\mathrm{P}$ (SRP). Dissolved inorganic N, total N, TP and SRP parameters were analyzed on an Alpkem RFA 300 auto-analyzer (OI Analytical, College Station, TX, USA) and TOC and 
DOC were analyzed with a Shimadzu 5000 TOC Analyzer (Shimadzu Scientific Instruments, Columbia, MD, USA).

\section{Plant biomass}

We counted the total number of leaves present on all 24 mangrove saplings before administering the defoliation treatment, just after applying the defoliation treatment, and at the end of the experiment. We calculated the change in the number of leaves as the final leaf count minus the leaf count immediately after applying the defoliation treatment. Finally, at the end of the experiment, we destructively sampled mangrove plants $(n=24)$ to quantify above and belowground plant biomass. We collected all the leaves from each plant to quantify total leaf biomass for each plant $(n=24)$. We quantified total aboveground woody biomass by clipping the prop roots and stems at the soil surface after the leaf biomass had been removed. We also determined belowground coarse root biomass from each entire core $\left(0.015 \mathrm{~m}^{3}\right)$ by washing away soil and collecting intact coarse roots, attached to the shoot, small fine, and unattached roots were not included in the coarse root biomass estimate. Leaf, woody, and coarse root samples were dried in an oven at $60^{\circ} \mathrm{C}$ for $48 \mathrm{~h}$. Completely dried samples were weighed, then finely ground and homogenized using an 800-D mixer/mill (spex SamplePrep, Metuchen, New Jersey, USA). Ground plant material was subsampled, oven-dried $\left(60^{\circ} \mathrm{C}\right)$ for $48 \mathrm{~h}$, weighed, combusted $\left(550^{\circ} \mathrm{C}\right.$ for $\left.4 \mathrm{~h}\right)$, and re-weighed to determine ash-free dry mass (g AFDM). 


\section{Plant and soil elemental stoichiometry}

We collected initial and final soil cores $(2 \mathrm{~cm}$ diameter $\times 20 \mathrm{~cm}$ depth; $n=12$ initial, $n=24$ final). We dried soil samples at $60^{\circ} \mathrm{C}$ for $48 \mathrm{~h}$. Ground soil material was subsampled, oven-dried $\left(60^{\circ} \mathrm{C}\right)$ for $48 \mathrm{~h}$, weighed, combusted $\left(550^{\circ} \mathrm{C}\right.$ for $\left.4 \mathrm{~h}\right)$, and reweighed to determine AFDM. Carbon and N content was measured using a Carlo Erba NA 1500 CHN Analyser (Carlo Erba, Milan, Italy). Phosphorus content was measured using the ash/acid extraction method followed by spectrophotometric analysis using the ascorbic acid method (Allen 1974, APHA 1998). We estimated elemental composition $(\% \mathrm{C}, \% \mathrm{~N}$, and $\% \mathrm{P})$ and elemental stoichiometry $(\mathrm{C}: \mathrm{N}, \mathrm{C}: \mathrm{P}$, and $\mathrm{N}: \mathrm{P})$ at three soil depths (0-2 cm, 2-10 cm, and 10-20 cm). All elemental compositions were calculated from molar mass, and elemental stoichiometry is reported in molar ratios.

\section{Root and leaf litter breakdown rates}

Within each mangrove-peat core, two mesh containers were deployed with ovendried leaf $(1.30 \pm 0.03 \mathrm{~g})$ and prop root litter $(1.30 \pm .0 .2 \mathrm{~g})$ material of known initial mass. We retrieved incubated litter at the end of the six-week study to quantify mass loss. We used oven-dried green litter which best represents organic matter inputs deposited during storms. By using the green leaf and prop root litter we were also able to better control for variation in initial litter chemical composition. We estimated breakdown rates (k) by $\ln$-transforming the proportion of AFDM remaining (using same methods for plant and soil AFDM above). We used the exponential decay model: $M_{42}=M_{0} \times e^{-k 42}$, where $\mathrm{M}_{0}$ is the initial litter mass on day $0, \mathrm{M}_{42}$ is the litter mass on day 42 . The slope of the linear regression of the ln-transformed AFDM remaining versus incubation time is $k$ 
(Benfield 2006). We also estimated elemental composition (\%C, \%N, and $\% \mathrm{P})$ and elemental stoichiometry $(\mathrm{C}: \mathrm{N}, \mathrm{C}: \mathrm{P}$, and $\mathrm{N}: \mathrm{P})$ of decomposing root and leaf litter following the same methods described above.

Soil $\mathrm{CO}_{2}$ efflux

Weekly soil $\mathrm{CO}_{2}$ efflux was measured during the day from all monoliths, using a portable infrared gas analyzer (LI-COR 8100, Lincoln, NE, USA) fit onto the embedded PVC pipe installed in each core. Each efflux measurement lasted for $75 \mathrm{~s}$. In addition to daytime soil $\mathrm{CO}_{2}$ efflux, we also measured nighttime $\mathrm{CO}_{2}$ efflux during the final week of the experiment. Nighttime $\mathrm{CO}_{2}$ efflux was measured following the same procedure used for daytime efflux.

\section{Data analyses}

We performed all statistical analyses using R Studio (R Core Team 2017 version 3.3.3). We ran repeated measures ANOVAs followed by Tukey HSD post-hoc tests to test the hypothesis that variation in effects of defoliation and $\mathrm{P}$ addition on changes in surface and porewater chemistry, and daytime $\mathrm{CO}_{2}$ efflux over time. For the variables measured only at the beginning and end of the experiment (soil organic matter content, the stoichiometry of soil, leaf and root litter, and root and litter $k$ ), we used ANOVA followed by a Tukey HSD test the differences among treatments. We considered results with an alpha less than 0.05 to be statistically significant. 


\section{RESULTS}

Experimental treatments

Initial mean leaf count for mangroves in control and $\mathrm{P}$ addition was $92 \pm 48$ and $86 \pm 36$, respectively. We removed an average of $137 \pm 36$ leaves from both the defoliation and $\mathrm{P}$ addition/defoliation treatment monoliths. At the end of the experiment, we measured the amount of orthophosphate remaining in the diffusers. Of the original 30 $\mathrm{g}$ of orthophosphate that was added to each diffuser in $\mathrm{P}$ addition treatments, an average of $1.21 \pm 0.11 \mathrm{mg} \mathrm{cm}^{-3}$ of orthophosphate diffused into the system over $42 \mathrm{~d}$.

\section{Physicochemical conditions}

Surface water temperature $\left(28.8 \pm 1.1^{\circ} \mathrm{C}\right.$, mean $\left.\pm \mathrm{SE}\right)$ and salinity $(31.2 \pm 3.7 \mathrm{ppt})$ were not affected by treatments and did not vary over time except for lower water temperature measured on July 19, 2013 compared to all other measurements (all, ANOVA $P>0.05)$.

Surface water SRP and TOC consistently increased with P addition throughout the study. Surface water DOC did not change with defoliation or P addition but steadily increased over time in all monoliths. Surface water DIN increased for all monoliths over time but was consistently lower with P addition. Finally, surface water TN varied with time and was not affected by defoliation or P addition, whereas TP increased with $\mathrm{P}$ addition and remained elevated over time (Table S1).

Porewater DOC was not affected by defoliation or P addition and did not change over time. However, porewater DIN varied with sample date and was higher in the defoliation, $\mathrm{P}$ addition, and $\mathrm{P}$ addition/defoliation treatments. Porewater SRP changed 
over time and was higher in the $\mathrm{P}$ addition treatments. Soil $\mathrm{CO}_{2}$ efflux varied over time and was suppressed by defoliation but was unaffected by P addition (Table S1).

\section{Plant biomass}

After the 42-d experiment, there were no differences in final mangrove leaf count among the four treatments (Fig. 2a; ANOVA, $P=0.24$ ). However, the change in leaf number showed a net decrease in the number of leaves on control plants $(-36 \pm 24)$ and no net change in the $\mathrm{P}$ addition treatment $(-4 \pm 11)$. Compared to the control, the defoliation and $\mathrm{P}$ addition/defoliation treatments had significant net increases in the number of leaves present and ended the experiment with $49 \pm 6$ and $58 \pm 13$ net increases in the number of leaves respectively (Fig. 2b; ANOVA, $P<0.01$ ),

Final leaf biomass AFDM was highest in the control and $\mathrm{P}$ addition and significantly lower in the defoliation and $\mathrm{P}$ addition/defoliation treatments than the controls (Fig. 3a; ANOVA, $P<0.01$ ). Individual leaf biomass (final leaf count/final leaf biomass AFDM) at 42-d was lower for the defoliation and $\mathrm{P}$ addition/defoliation treatments than the controls (ANOVA, $P<0.01$ ).

Aboveground woody biomass (g AFDM) was the same across all treatments at the end of the experiment (Fig. 3b; ANOVA, $P>0.05$ ). Belowground coarse root biomass was the same across all treatments at the end of the experiment (Fig. 3c; ANOVA, $P>$ 0.05). The average root-to-shoot biomass ratio was $1.13 \pm 0.18$ and was the same across all treatments at the end of the experiment (ANOVA, P > 0.05). 


\section{Plant and soil elemental stoichiometry}

Soil \% C, \% N, and \% P were not different at any soil depth for either defoliation or P addition (all responses, $P>0.05$, Table $\mathrm{S} 2$ ). Soil C:N, C:P, and N:P were not different at any soil depth for either defoliation or $\mathrm{P}$ addition (all responses, $\mathrm{P}>0.05$, Table S3). Final leaf $\% \mathrm{C}$ and $\% \mathrm{~N}$ was not different among the four treatments (ANOVA, $P>0.05)$; however, final leaf $\% \mathrm{P}$ was higher in the $\mathrm{P}$ addition treatments compared to the controls (ANOVA, $\mathrm{P}<0.01$ ). Plants increased \% $\mathrm{P}$ in live leaf and root tissue with $\mathrm{P}$ addition (Fig. 4, $P=0.01$ ). Final leaf $\mathrm{C}: \mathrm{N}$ was not different among the four treatments (ANOVA, $P>0.05$ ); however, leaf C:P and N:P were lower with defoliation (ANOVA, both $P=0.02)$ and added $\mathrm{P}($ ANOVA, both $\mathrm{P}<0.01$; Table S3). Final root $\mathrm{C}: \mathrm{N}$ increased within the $\mathrm{P}$ addition treatments (ANOVA, $P=0.04$ ) and final root $\mathrm{C}: \mathrm{P}$ was lower within the $\mathrm{P}$ addition treatments (ANOVA, $P<0.01$; Table S3). Final root N:P was lower with $\mathrm{P}$ addition compared to controls (ANOVA, $P<0.01$ ) and there was an interaction between $\mathrm{P}$ addition and defoliation which lowered $\mathrm{N}: \mathrm{P}$ compared to controls (ANOVA, $P=0.04$; Table S3).

\section{Root and leaf litter breakdown rates}

Decomposing root and leaf litter deployed in each experimental core did not differ in $\% \mathrm{C}, \% \mathrm{~N}$, or $\% \mathrm{P}$. Decomposing leaf $k$ was not different among treatments (Fig. 5a; ANOVA, $P>0.05)$. However, decomposing root material showed slower $k$ in defoliation treatments compared to the controls (Fig. 5b; ANOVA, $P=0.03$ ). At the end of the experiment, $\% \mathrm{C}$ and $\% \mathrm{~N}$ of decomposing root and leaf litter were not different among the 
four treatments; however, the $\% \mathrm{P}$ in decomposing root litter, but not leaf litter, was higher with $\mathrm{P}$ addition (Table S2).

Decomposing root litter C:N, C:P, and N:P were not different among treatments (all responses, $P>0.05$, Table $\mathrm{S} 3$ ). However, $\mathrm{P}$ addition decreased decomposing leaf litter C:P (ANOVA, $P=0.03$ ) and N:P (ANOVA, $P=0.01$; Table S3). Decomposing leaf litter $\mathrm{C}: \mathrm{N}$ was not different among treatments (ANOVA, $P>0.05$ ).

Soil $\mathrm{CO}_{2}$ efflux

Weekly soil $\mathrm{CO}_{2}$ efflux was suppressed in the defoliation and $\mathrm{P}$ addition/defoliation treatments and varied over time (Fig. 6; ANOVA, $P<0.05$ ). We also plotted the response of day and nighttime $\mathrm{CO}_{2}$ efflux against the total amount of $\mathrm{P}$ released from each $\mathrm{P}$ addition treatment. Daytime $\mathrm{CO}_{2}$ efflux was not correlated to increased $\mathrm{P}$ released over the six weeks (Fig. $7 \mathrm{a} ; \mathrm{R}^{2}=0.16, P=0.19$ ). Nighttime $\mathrm{CO}_{2}$ was positively associated with the total amount of $\mathrm{P}$ released over the course of the experiment (Fig. $\left.7 \mathrm{~b} ; \mathrm{R}^{2}=0.37, P=0.04\right)$. However, both trends were positive.

\section{DISCUSSION}

Our objective was to understand how exposure to a subsidy (P addition) can influence effects of episodic stress (defoliation) on $\mathrm{C}$ and nutrient cycling of mangrove plants and soils. We predicted that addition of $\mathrm{P}$ would increase mangrove leaf and root $\mathrm{P}$ content, soil $\mathrm{P}$ content, litter breakdown rates, and soil $\mathrm{CO}_{2}$ efflux. We found that $\mathrm{P}$ addition resulted in net increases in plant $\mathrm{P}$ storage, but soil $\mathrm{P}$ did not change. We detected increases in nighttime soil $\mathrm{CO}_{2}$ efflux attributed to $\mathrm{P}$ addition; however, this 
effect was not present during daytime measurements. We expected defoliation would increase soil $\mathrm{CO}_{2}$ efflux because of increased soil microbial and root respiration, however, we found defoliation decreased soil $\mathrm{CO}_{2}$ efflux. Decreased soil $\mathrm{CO}_{2}$ efflux indicates a potential below-ground pathway to maintain soil $\mathrm{C}$ storage following disturbance. Finally, we predicted that plants with added $\mathrm{P}$ would regenerate leaves more quickly than those without added $\mathrm{P}$, but our results indicate that $\mathrm{P}$ addition does not enhance mangrove sapling leaf growth following defoliation after 42-d.

Mangroves quickly took up supplemental $\mathrm{P}$ and incorporated it into living biomass. Our results only partially supported our prediction that $\mathrm{P}$ addition would result in increases in $\mathrm{P}$ in the soil and mangrove leaves and roots. Phosphorus addition increased $\mathrm{P}$ concentrations in mangrove leaves and roots but did not affect soil total $\mathrm{P}$ concentrations. Mangrove saplings in our experiment were likely more competitive than soil microbes and consequentially able to incorporate more $\mathrm{P}$ into living biomass, especially since we added inorganic P (Schachtman et al. 1998; Reef et al. 2010). Incorporating the available $\mathrm{P}$ in living biomass resulted in stoichiometric changes within leaves which had decreased C:P and N:P ratios. Mangroves removed and sequestered added $\mathrm{P}$ from the soil or water column where $\mathrm{P}$ was dissolved, incorporating it into living leaf and root biomass. Phosphorus inputs following storm surges may result in plant uptake of available $\mathrm{P}$, provided the soil is not $\mathrm{P}$ limited.

Nutrient addition has been shown to increase mangrove leaf biomass (Feller et al. 2015), decrease the proportion of belowground biomass relative to aboveground biomass (Castañeda-Moya et al. 2012), and promote mangrove productivity following a storm (Lovelock et al. 2011). Contrary to our initial hypothesis that predicted P addition would 
help mangroves recover from defoliation, we did not see effects of $\mathrm{P}$ addition on living leaf biomass. Therefore, we predicted $\mathrm{P}$ addition would lead to increased mangrove biomass and help defoliated mangroves regenerate leaves more quickly. Interestingly, $\mathrm{P}$ addition did not result in increased number of leaves nor did it enhance the recovery of leaf count in the $\mathrm{P}$ addition/defoliation treatment. Instead, $\mathrm{P}$ addition treatment allowed mangrove plants to maintain their leaves throughout the experiment whereas mangroves in the control treatment on average lost 0.85 leaves per day. While mangrove plants typically have the highest leaf fall during summer months, when our study was conducted, only the controls had net decreases in the number of leaves (Lugo and Snedaker 1974). The growth of mangroves in the control treatment was likely P limited indicating that marine-derived $\mathrm{P}$ subsidies are essential for mangrove growth.

Even though the final leaf count was similar across treatments, the total biomass measured after the 42-d study was reduced in the defoliation and the $\mathrm{P}$ addition/defoliation treatment. Leaves regenerated quickly following the defoliation as previously documented (Danielson et al. 2017); however, the new leaves were smaller and did not reach pre-treatment sizes within 42-d. Phosphorus exposure following defoliation did not promote leaf biomass recovery. The lack of a response to $\mathrm{P}$ addition in aboveground biomass production is another potential mechanism behind mangrove forest resilience as the over-production of leaf biomass, without similar increases in belowground biomass, enhances mangrove susceptibility to hurricane-induced damage (Feller et al. 2015). Chronic nutrient loading in coastal ecosystems may exacerbate the damage caused by storm surge by disproportionally increasing aboveground biomass relative to belowground biomass (Lovelock et al. 2009); whereas, storm-delivered pulses 
of nutrient subsidies, occurring in tandem with the disturbance, may aid in forest recovery (Herbert et al. 1999). Perhaps the timing of nutrient addition, either long before or following hurricane disturbance, regulates the recovery process.

Despite our prediction that $\mathrm{P}$ would stimulate litter breakdown and soil respiration rates, $\mathrm{P}$ addition did not increase the breakdown of roots and leaf litter, indicating that soil microbial activities influencing litter breakdown were not affected by added P. Microbial communities in reduced environments, like wetland soils, may be unable to use excess $\mathrm{P}$ because of oxygen limitation, suggesting greater thermodynamic than nutrient limitation in these ecosystems (Helton et al. 2015). It is also important to note that there was no difference in $\% \mathrm{P}$ in leaf litter and bulk soil and only a slight increase $0.01 \%$ in root liter $\mathrm{P}$ with the addition of $\mathrm{P}$ (Table S2). However, leaf litter C:P and N:P was lower with $\mathrm{P}$ addition indicating increased $\mathrm{P}$ availability resulted in higher $\mathrm{P}$ content relative to $\mathrm{C}$ and N. Previous work has shown that the effects of long-term nutrient addition on mangrove litter breakdown is mediated by changes in litter quality instead of direct effects of nutrient addition on breakdown (Keuskamp et al. 2015). In our study, we did not see direct effects of $\mathrm{P}$ enrichment on litter breakdown. However, if we were to use the P-enriched biomass for breakdown litter, as is observed in coastal mangroves of Shark River Slough, we would potentially have found increased breakdown rates (Keuskamp et al. 2015). Episodic P deliveries that co-occur with disturbance may be less likely to enhance litter breakdown, which may help maintain C storage in wetlands.

Defoliation reduced breakdown rates of the more recalcitrant root litter which may have been caused by decreases in root exudates (Vančura and Staněk 1975). In our experiment, root litter breakdown was likely more dependent on priming from plant 
exudates than the inorganic addition of P (Kuzyakov 2002). The release of root exudates and rhizosphere priming provide energy sources to the soil microbial community to enhance organic matter breakdown but they also represent an energy investment for the plant (Dijkstra et al. 2013). Therefore, the reduction of decomposition in the defoliation treatment may indicate that defoliated mangroves invest available energy into the production of leaves and decrease root exudate release. The suppression of below-ground breakdown following a loss of above-ground $\mathrm{C}$ is a potential pathway towards mangrove forest recovery of the valuable ecosystem service of storing C.

We detected a potential pathway for maintaining $\mathrm{C}$ stocks in mangrove forests following disturbance. In our study, weekly daytime soil efflux of $\mathrm{CO}_{2}$ was reduced in the defoliation treatments. Previous studies in grassland ecosystems have also measured decreased soil respiration following defoliation (Guitian and Bardgett 2000). Similarly, previous studies within the Everglades have indicated that daytime net ecosystem exchange returns to pre-disturbance levels as soon as two years following a hurricane (Barr et al. 2012). The recovery of daytime $\mathrm{CO}_{2}$ uptake after a hurricane reflects the resilience of $\mathrm{C}$ storage to the frequent disturbance from hurricanes in the Florida Everglades region (Smith et al. 1994, Zhang et al. 2008). Reduced C losses could represent the soil contribution to mitigating $\mathrm{C}$ loss from the system through the reduced breakdown of recalcitrant decomposing material; however, more evidence is needed to link soil $\mathrm{CO}_{2}$ efflux to net ecosystem exchange. Consistent with the expectation that $\mathrm{P}$ increases $\mathrm{CO}_{2}$ loss from the soil, we detected a positive relationship between the total amount of $\mathrm{P}$ released and nighttime $\mathrm{CO}_{2}$ efflux, in the $\mathrm{P}$ addition treatments. Increased nighttime $\mathrm{CO}_{2}$ efflux was evident following Hurricane Wilma (Barr et al. 2012). Our 
findings suggest that for each additional gram of $\mathrm{P}$ diffused into the $\mathrm{P}$ addition cores, daily $\mathrm{CO}_{2}$ efflux was increased by $703 \mathrm{mg} \mathrm{C} \mathrm{m}^{-2} \mathrm{~d}^{-1}$.

Globally, carbon losses are increasing in coastal wetlands (DeLaune and White 2012; Chanda et al. 2016), so understanding the mechanisms by which mangrove plants and soils recover (or not) from high-energy storms is necessary to making predictions about coastal $\mathrm{C}$ storage following disturbances. We predicted the greatest declines in plant $\mathrm{C}$ would be attributed to defoliation. However, this was only partially supported by our results. In our experiment, neither $\mathrm{P}$ addition or defoliation resulted in changes in aboveground woody biomass likely because the experiment was not long enough to capture changes in the longer-lived and more stable components of plant biomass (Clough 1992). Similarly, in our experiment, final leaf count was the same across all treatments, but leaves were smaller. The leaves in the defoliation treatment regenerated within six weeks to similar counts as the non-defoliation treatments. The rapid recovery of leaves is a potential mechanistic pathway of mangrove regeneration. If the mangrove failed to grow new leaves, they would die and expose patches of previously shaded soil and litter to photodegradation (Scully et al. 2004; Maie et al. 2008). However, the reduction in total leaf biomass within the defoliated mangroves supports our initial hypothesis and is one mechanism for $\mathrm{C}$ loss following a storm.

Interestingly, defoliation resulted in unanticipated mechanisms that likely support maintenance of $\mathrm{C}$ storage such as, reduced recalcitrant root breakdown rates and soil $\mathrm{CO}_{2}$ efflux. Phosphorus uptake by plants and lack of response in litter breakdown with $\mathrm{P}$ addition and the suppression of soil $\mathrm{CO}_{2}$ efflux and breakdown with defoliation could represent pathways towards ecosystem resilience. However, there were also potential 
mechanisms that inhibited mangrove resiliency: We predicted that soil $\mathrm{C}$ losses would be attributed to $\mathrm{P}$ addition and found evidence to support this hypothesis; $\mathrm{P}$ addition enhanced $\mathrm{CO}_{2}$ efflux at night. We had also predicted that $\mathrm{P}$ addition would help offset adverse effects of defoliation; however, the plant/defoliation treatments often displayed similar patterns to the dominant treatment that was controlling a particular response variable. We only saw an interaction between added $\mathrm{P}$ and defoliation in the leaf $\mathrm{P}$ content where the plant/defoliation treatment had the highest $\mathrm{P}$.

Our study illustrates how mangroves respond to interactions of stress (defoliation) and subsidy (P addition) common to coastal wetlands. High-energy storms can defoliate large areas of mangrove forests and often leave behind P-rich marine sediment from tidal surge. However, there are limitations to small-scale, short-term mesocosm studies. We were able to quantify short responses of mangroves to defoliation and $\mathrm{P}$ addition, but long-term interactive subsidy-stress effects are likely different. Although our study provides a controlled setting for simulating interactions between disturbance and nutrient enrichment, we were unable to replicate conditions of high-energy storms. For example, we added nutrient subsidies and root litter directly to soils instead of depositing it on the soil surface to isolate belowground soil responses where the majority of $\mathrm{C}$ is stored. Despite these limitations, our experimental manipulation enabled us to identify essential mechanisms that help inform how mangroves respond in situ to subsidies and stresses as well as the differential sensitivities of plant and soil responses.

Mangrove forests provide critical ecosystem services such as timber, fuel, medicine, habitat for wildlife, wave attenuation, sediment accumulation, and $\mathrm{C}$ sequestration (Twilley 1995; Kathiresan and Bingham 2001; Saenger 2002; Manson et al. 
2005; Mazda et al. 2007, Zhang et al. 2012; Jerath et al. 2016). The ability of mangrove forests to provide these services depends upon their recovery and adaptation to highenergy disturbance events, such as tropical storms and hurricanes. Changes in the pulsing dynamic of storm frequency and intensity with a changing climate may destabilize coastal wetlands if these ecosystems are unable to adapt (Odum et al. 1995). Also, nonlinear increases in sea-level rise increase presses of subsidies and stresses to coastal ecosystems that may reduce resilience if coastal areas become too quickly inundated with rising water levels. It is essential to understand specific mechanisms behind ecosystem resilience to natural stressors and subsidies to better inform ecosystem management and keep anthropogenic impacts within a "safe operating space" (Green et al. 2017). By identifying potential tipping points following disturbance, we can better predict how climate change and anthropogenic stressors may interact to alter coastal wetland ecosystem function.

\section{ACKNOWLEDGMENTS}

We thank S. Charles, L. Marazzi, D. Mills, B. Wilson, and L. Zhai for providing extensive feedback during the development of the manuscript. Funding for this research was provided by the National Science Foundation (NSF) award (DBI-1237517) to the Florida Coastal Everglades Long Term Ecological Research Program. We thank the Everglades Section of the South Florida Water Management District and Everglades National Park for providing facilities support during this research. 


\section{REFERENCES}

Allen SE, Grimshaw HM, Parkinson JA, Quarmby C (1974) Chemical analysis of ecological materials. Blackwell Scientific Publications.

Alongi DM (2008) Mangrove forests: Resilience, protection from tsunamis, and responses to global climate change. Estuarine, Coastal and Shelf Science 76:1-13.

Barr JG, Engel V, Smith TJ, Fuentes JD (2012) Hurricane disturbance and recovery of energy balance, $\mathrm{CO}_{2}$ fluxes and canopy structure in a mangrove forest of the Florida Everglades. Agricultural and Forest Meteorology 153:54-66.

Benfield EF (2006) Decomposition of leaf material. Methods in Stream Ecology 711720.

Bianchi TS, Allison MA, Zhao J, Li X, Comeaux RS, Feagin RA, Kulawardhana RW (2013) Historical reconstruction of mangrove expansion in the Gulf of Mexico: linking climate change with carbon sequestration in coastal wetlands. Estuarine, Coastal and Shelf Science, 119:7-16.

Boesch DF (1974) Diversity, stability and response to human disturbance in estuarine ecosystems. In Proceedings of the First International Congress of Ecology. Pudoc, Wageningen 109-114.

Boyer JN, Fourqurean JW, \& Jones RD (1999) Seasonal and long-term trends in the water quality of Florida Bay (1989-1997). Estuaries 22:417-430.

Castañeda-Moya E, Twilley RR, Rivera-Monroy VH, Zhang K, Davis SE, and Ross M (2010) Sediment and nutrient deposition associated with Hurricane Wilma in mangroves of the Florida Coastal Everglades. Estuaries and Coasts 33:45-58.

Castañeda-Moya E, Twilley RR, Rivera-Monroy VH (2012) Allocation of biomass and net primary productivity of mangrove forests along environmental gradients in the Florida Coastal Everglades, USA. Forest Ecology and Management 307:226-241.

Chambers LG, Davis SE, Troxler T, Boyer JN, Downey-Wall A, Scinto LJ (2014) Biogeochemical effects of simulated sea level rise on carbon loss in an Everglades mangrove peat soil. Hydrobiologia 726:195-211.

Chanda A, Mukhopadhyay A, Ghosh T, Akhand A, Mondal P, Ghosh S, ... \& Salehin M (2016) Blue carbon stock of the Bangladesh Sundarban Mangroves: what could be the scenario after a century? Wetlands 36:1033-1045.

Chen R, Twilley RR (1999a) A simulation model of organic matter and nutrient accumulation in mangrove wetland soils. Biogeochemistry 44:93-118. 
Chen R, Twilley RR (1999b) Patterns of mangrove forest structure and soil nutrient dynamics along the Shark River Estuary, Florida. Estuaries 22:955-970.

Childers DL, Boyer JN, Davis SE, Madden CJ, Rudnick DT, Sklar FH (2006). Relating precipitation and water management to nutrient concentrations in the oligotrophic" upside-down" estuaries of the Florida Everglades. Limnology and Oceanography 51:602-616.

Clough BF (1992) Primary productivity and growth of mangrove forests. Tropical Mangrove Ecosystems 225-249.

Comeaux RS, Allison MA, Bianchi TS (2012) Mangrove expansion in the Gulf of Mexico with climate change: Implications for wetland health and resistance to rising sea levels. Estuarine, Coastal and Shelf Science 96:81-95.

Danielson TM, Rivera-Monroy VH, Castañeda-Moya E, Briceño H, Travieso R, Marx BD, Gaiser E, Farfán LM (2017) Assessment of Everglades mangrove forest resilience: Implications for above-ground net primary productivity and carbon dynamics. Forest Ecology and Management 404:115-125.

DeLaune RD, White JR (2012) Will coastal wetlands continue to sequester carbon in response to an increase in global sea level: a case study of the rapidly subsiding Mississippi River deltaic plain. Climatic Change 110:297-314.

Deng Y, Solo-Gabriele HM, Laas M, Leonard L, Childers DL, He Guoqing, Engel V. (2010) Impacts of hurricanes on surface water flow within a wetland. Journal of Hydrology 392(3):164-173.

Dijkstra FA, Carrillo Y, Pendall E, Morgan JA (2013) Rhizosphere priming: a nutrient perspective. Frontiers in Microbiology 4:216.

Doyle TW, Smith TJ, Robblee MB III (1995) Wind damage effects of Hurricane Andrew on mangrove communities along the southwest coast of Florida, USA. Journal of Coastal Research Special Issue 21:159-168.

Duever MJ, Meeder JF, Meeder LC, McCollom JM (1994) The climate of South Florida and its role in shaping the Everglades ecosystem. In Everglades: The ecosystem and its restoration, ed. Davis SM, Ogden JC, 225-248.

Feller IC, McKee KL, Whigham DF, O’Neill JP (2003a) Nitrogen vs. phosphorus limitation across an ecotonal gradient in a mangrove forest. Biogeochemistry 62:145-175. 
Feller IC, Whigham DF, McKee KL, Lovelock CE, (2003b) Nitrogen limitation of growth and nutrient dynamics in a disturbed mangrove forest, Indian River Lagoon, Florida. Oecologia 134:405-414.

Feller IC, Dangremond EM, Devlin DJ, Lovelock CE, Proffitt CE, Rodriguez W (2015) Nutrient enrichment intensifies hurricane impact in scrub mangrove ecosystems in the Indian River Lagoon, Florida, USA. Ecology 96:2960-2972.

Fourqurean JW, Jones RD, Zieman JC (1993) Process influencing water column nutrient characteristics and phosphorus limitation of phytoplankton biomass in Florida Bay, FL, USA: inferences from spatial distributions. Estuarine, Coastal and Shelf Science 36:295-314.

Green AJ, Alcorlo P, Peeters ET, Morris EP, Espinar JL, Bravo-Utrera MA, ... \& Mooij WM (2017) Creating a safe operating space for wetlands in a changing climate. Frontiers in Ecology and the Environment 15:99-107.

Guitian R. Bardgett RD (2000) Plant and soil microbial responses to defoliation in temperate semi-natural grassland. Plant and Soil 220:271.

Helton AM, Ardón M, Bernhardt ES (2015) Thermodynamic constraints on the utility of ecological stoichiometry for explaining global biogeochemical patterns. Ecology Letters 18:1049-1056.

Herbert DA, Fownes JH, Vitousek PM (1999) Hurricane damage to a Hawaiian forest: nutrient supply rate affects resistance and resilience. Ecology 80:908-920.

Holling CS (1973) Resilience and stability of ecological systems. Annual Review of Ecology and Systematics 4:1-23.

Howarth and Fisher (1976) Carbon, nitrogen, and phosphorus dynamics during leaf decay in nutrient-enriched stream microecosystems. Freshwater Biology 6:221-228.

Jerath M, Bhat M, Rivera-Monroy VH, Castañeda-Moya E, Simard M, Twilley RR (2016) The role of economic, policy, and ecological factors in estimating the value of carbon stocks in Everglades mangrove forests, South Florida, USA. Environmental Science \& Policy 66:160-169.

Johnstone, JF, Allen CD, Franklin JF, Frelich LE, Harvey BJ, Higuera PE, Mack MC, Meentemeyer RK, Metz MR, Perry GL, Schoennagel T (2016) Changing disturbance regimes, ecological memory, and forest resilience. Frontiers in Ecology and the Environment 14:369-378.

Kathiresan K, Bingham BL (2001) Biology of mangroves and mangrove ecosystems. Advances in Marine Biology 40:81-251. 
Keuskamp JA, Hefting MM, Dingemans BJ, Verhoeven JT, Feller IC (2015) Effects of nutrient enrichment on mangrove leaf litter decomposition. Science of the Total Environment t508: 402-410.

Krauss KW, Doyle TW, Twilley RR, Smith TJI (2005) Woody debris in the mangrove forests of South Florida. Biotropica 37:9-15.

Kuzyakov Y (2002) Factors affecting rhizosphere priming effects (review). Journal of Plant Nutrition and Soil Science 165: 382-396.

Lovelock CE, Feller IC, McKee KL, Engelbrecht BM, Ball MC (2004) The effect of nutrient enrichment on growth, photosynthesis and hydraulic conductance of dwarf mangroves in Panama. Functional Ecology 18:25-33.

Lovelock CE, Ball MC, Choat B, Engelbrecht BMJ, Holbrook NM, Feller IC (2006) Linking physiological processes with mangrove forest structure: phosphorus deficiency limits canopy development, hydraulic conductivity and photosynthetic carbon gain in dwarf Rhizophora mangle. Plant, Cell, and Environment 29:793-802.

Lovelock CE, Feller IC, Adame MFA, Reef RR, Penrose HM, Wei L, Ball MC (2011) Intense storms and the delivery of materials that relieve nutrient limitations in mangroves of an arid zone estuary. Functional Plant Biology 38:514-522.

Lugo AE, Snedaker SC (1974) The ecology of mangroves. Annual Review of Ecology and Systematics, 5(1), 39-64.

Lugo AE (2000) Effects and outcomes of Caribbean hurricanes in a climatic change scenario. Science of the Total Environment 262: 243-251.

Lugo AE (2008) Visible and invisible effects of hurricanes on forest ecosystems: An international review. Austral Ecology 33:368-398.

Maie N, Pisani O, Jaffé R (2008) Mangrove tannins in aquatic ecosystems: Their fate and possible influence on dissolved organic carbon and nitrogen cycling. Limnology and Oceanography, 53:160.

Manson FJ, Loneragan NR, Skilleter GA, Phinn SR (2005) An evaluation of the evidence for linkages between mangroves and fisheries: a synthesis of the literature and identification of research directions. Oceanography and Marine Biology 43:483.

Mazda Y, Wolanski E, Ridd P (2007) The role of physical processes in mangrove environments: manual for the preservation and utilization of mangrove ecosystems. Terrapub. 
Michener WK, Blood ER, Bildstein KL, Brinson MM, Gardner LR (1997) Climatic change, hurricanes and tropical storms, and rising sea level in coastal wetlands. Ecological Applications 7:770-801.

Noe GB, Childers DL, Jones RD (2001) Phosphorus biogeochemistry and the impact of phosphorus enrichment: Why is the Everglades so unique? Ecosystems 4:603-624.

Odum WE, Odum EP. and Odum HT, (1995) Nature's pulsing paradigm. Estuaries 18(4):547.

Piou C, Feller IC, Berger U, Chi F (2006) Zonation patterns of Belizean offshore mangrove forests 41 years after a catastrophic hurricane. Biotropica 38:365-374.

R Core Team (2017). R: A language and environment for statistical computing. $\mathrm{R}$ Foundation for Statistical Computing, Vienna, Austria. URL https://www.Rproject.org/.

Reef R, Feller IC, Lovelock CE (2010) Nutrition of mangroves. Tree Physiology, 30(9), 1148-1160.

Robinson CT, Gessner MO (2000) Nutrient addition accelerates leaf breakdown in alpine Springbrook. Oceologica 122:258-263.

Saenger P (2002) Mangrove ecology, silviculture and conservation. Springer Science \& Business Media.

Schachtman DP, Reid RJ, Ayling SM (1998) Phosphorus uptake by plants: from soil to cell. Plant Physiology, 116(2), 447-453.

Scully NM, Maie N, Dailey SK, Boyer JN, Jones RD, Jaffé R (2004) Early diagenesis of plant-derived dissolved organic matter along a wetland, mangrove, estuary ecotone. Limnology and Oceanography 49:1667-1678.

Sistla SA, Schimel JP (2012) Stoichiometric flexibility as a regulator of carbon and nutrient cycling in terrestrial ecosystems under change. New Phytologist 196:68-78.

Sherman RE, Fahey TJ, Martinez P (2001) Hurricane impacts on a mangrove forest in the Dominican Republic: Damage patterns and early recovery. Biotropica 33:393-408.

Smith TJ III, Robblee MB, Wanless HR, Doyle TW (1994) Mangroves, hurricanes, and lightning strikes. BioScience 44:256-262.

Smith TJ III, Anderson GH, Balentine K, Tilling G, Ward GA, Whelan KRT (2009) Cumulative impacts of hurricanes on Florida mangrove ecosystems: sediment deposition, storm surges and vegetation. Wetlands 29:24-34. 
Twilley RR, Chen RH, Hargis T (1992) Carbon sinks in mangroves and their implications to carbon budget of tropical coastal ecosystems. Water, Air, \& Soil Pollution 64:265-288.

Twilley RR (1995) Properties of mangrove ecosystems related to the energy signature of coastal environments. In 'Maximum Power: The Ideas and Applications of HT Odum’ (Ed. CAS Hall.) 43-62.

Vančura V, Staněk, M (1975) Root exudates of plants. Plant and Soil 43: 547-559. White PS, Jentsch, A (2001) The search for generality in studies of disturbance and ecosystem dynamics. In Progress in Botany (pp. 399-450). Springer, Berlin, Heidelberg.

Zhang K, Simard M, Ross M, Rivera-Monroy VH, Houle P, Ruiz P, .. \& Whelan K (2008) Airborne laser scanning quantification of disturbances from hurricanes and lightning strikes to mangrove forests in Everglades National Park, USA. Sensors 8:2262-2292.

Zhang K, Liu H, Li Y, Xu H, Shen J, Rhome J, Smith TJ III (2012) The role of mangroves in attenuating storm surges. Estuarine, Coastal and Shelf Science 102103:11-23.

\section{FIGURES}

Figure 1 Diagram of the outdoor experimental wetlands and mangrove-peat monolith structure. Six experimental wetland mesocosms contained four mangrove-peat monoliths each. Each mesocosm was designated as phosphorus added $(+\mathrm{P})$ or no phosphorus added (-P). Within each mesocosm, mangrove-peat monoliths were designated as defoliated (L) or non-defoliated $(+\mathrm{L})$. Each mangrove-Peat monolith was contained in a $25 \times 28 \mathrm{~cm}$ perforated bucket equipped with a porewater sipper, $10 \mathrm{~cm}$ diameter collar for $\mathrm{CO}_{2}$ soil efflux measurements, diffusers that were either empty or contained granular orthophosphate in the $+\mathrm{P}$ treatments, and root and leaf decomposition material. 
Figure 2 Final leaf count (a) and delta leaf count (b) for the four treatments control, leaves removed (-L), phosphorus addition $(+\mathrm{P})$, and leaves removed and phosphorus addition (+P/-L). Final leaf count (a) was determined by counting the total number of live leaves present on each mangrove plant on the last day of the experiment. Delta leaf count (b) was determined by subtracting the number of leaves after the defoliation treatment was administered from the final leaf count. Treatments were compared using an ANOVA followed by a Tukey HSD for comparison. P-values less than 0.05 were considered significant.

Figure 3. Final aboveground leaf biomass (a), final aboveground woody biomass (b), and final belowground coarse woody biomass (c) for the four treatments control, leaves removed $(-\mathrm{L})$, phosphorus addition $(+\mathrm{P})$, and leaves removed and phosphorus addition $(+\mathrm{P} /-\mathrm{L})$. Biomass is reported as ash-free dry mass (AFDM). Treatments were compared using an ANOVA followed by a Tukey HSD for comparison. P-values less than 0.05 were considered significant.

Figure 4. Final leaf (a) and root (b) live biomass \% phosphorus (P) for the four treatments control, leaves removed (-L), $\mathrm{P}$ addition $(+\mathrm{P})$, and leaves removed and $\mathrm{P}$ addition $(+\mathrm{P} /-$ L). Treatments were compared using an ANOVA followed by a Tukey HSD for comparison. P-values less than 0.05 were considered significant.

Figure 5. Decomposing leaf (a) and root (b) breakdown rates $\left(k \mathrm{~d}^{-1}\right)$ for the four treatments control, leaves removed (-L), phosphorus addition $(+\mathrm{P} /-\mathrm{L})$, and leaves 
removed and phosphorus addition $(+\mathrm{P} /-\mathrm{L})$. Treatments were compared using an ANOVA followed by a Tukey HSD for comparison. $P$-values less than 0.05 were considered significant.

Figure 6.Weekly daytime soil $\mathrm{CO}_{2}$ efflux $\left(\mathrm{CO}_{2}-\mathrm{C}, \mathrm{mg} \mathrm{C} \mathrm{m} \mathrm{m}^{-2} \mathrm{~d}^{-1}\right)$ for all for the four treatments control, leaves removed (-L), phosphorus addition $(+\mathrm{P} /-\mathrm{L})$, and leaves removed and phosphorus addition (+P/-L). Treatments were compared using a repeated measures ANOVA followed by a Tukey HSD for comparison. P-values less than 0.05 were considered significant.

Figure 7. Final (a) daytime and (b) nighttime soil $\mathrm{CO}_{2}$ efflux $\left(\mathrm{CO}_{2}-\mathrm{C}, \mathrm{mg} \mathrm{C} \mathrm{m}^{-2} \mathrm{~d}^{-1}\right)$ plotted against the total amount of phosphorus ( $\mathrm{g}$ ) released by diffusion by the end of the 42-d experiment. Phosphorus released was calculated by subtracting the amount of granular orthophosphate remaining in the diffusers at the end of the experiment from the starting amount of orthophosphate. Linear regression (solid line) and 95\% confidence interval (dashed lines) are plotted when significant $(P<0.05)$. 
Figure 1.

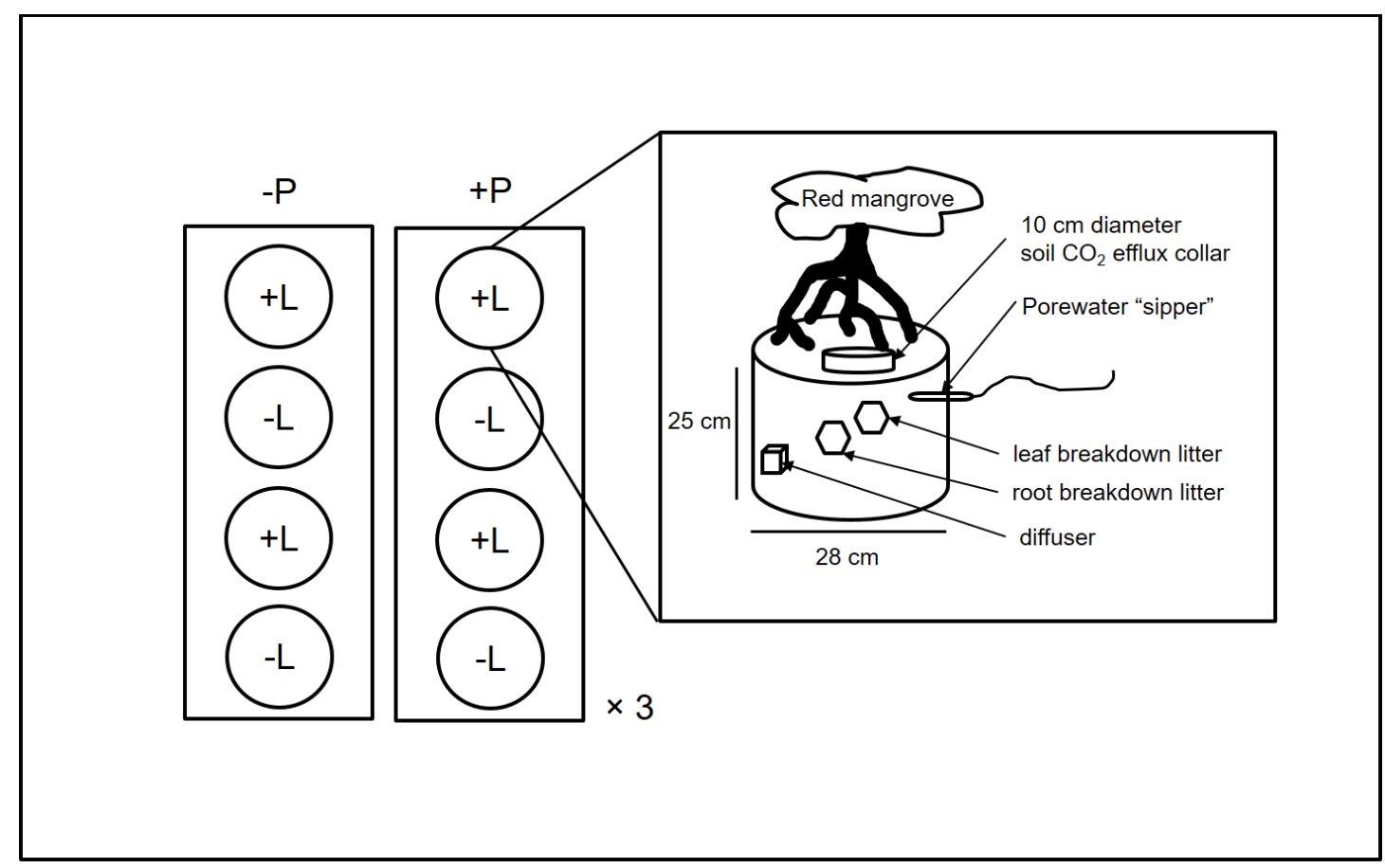


Figure 2.
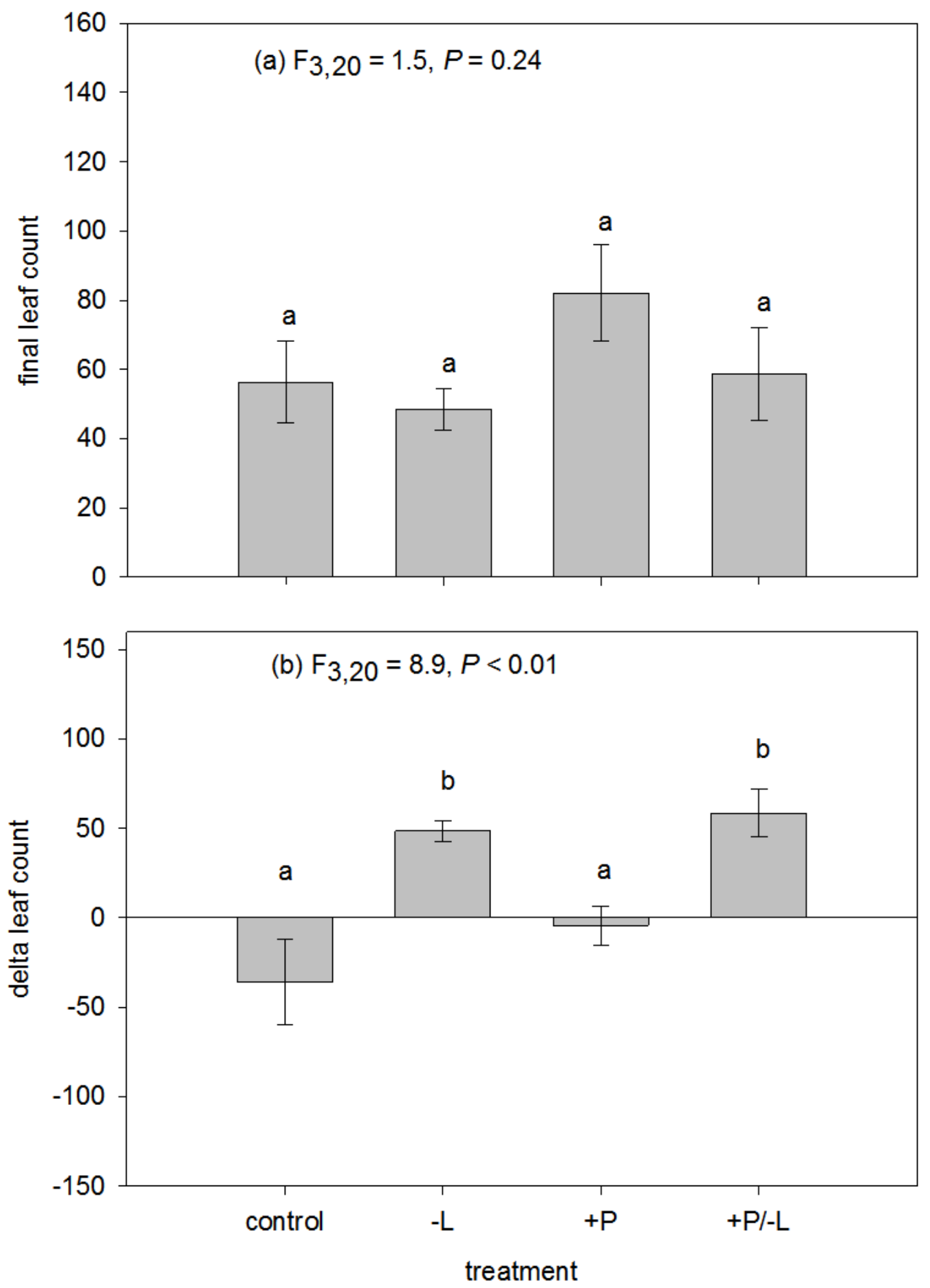
Figure 3.
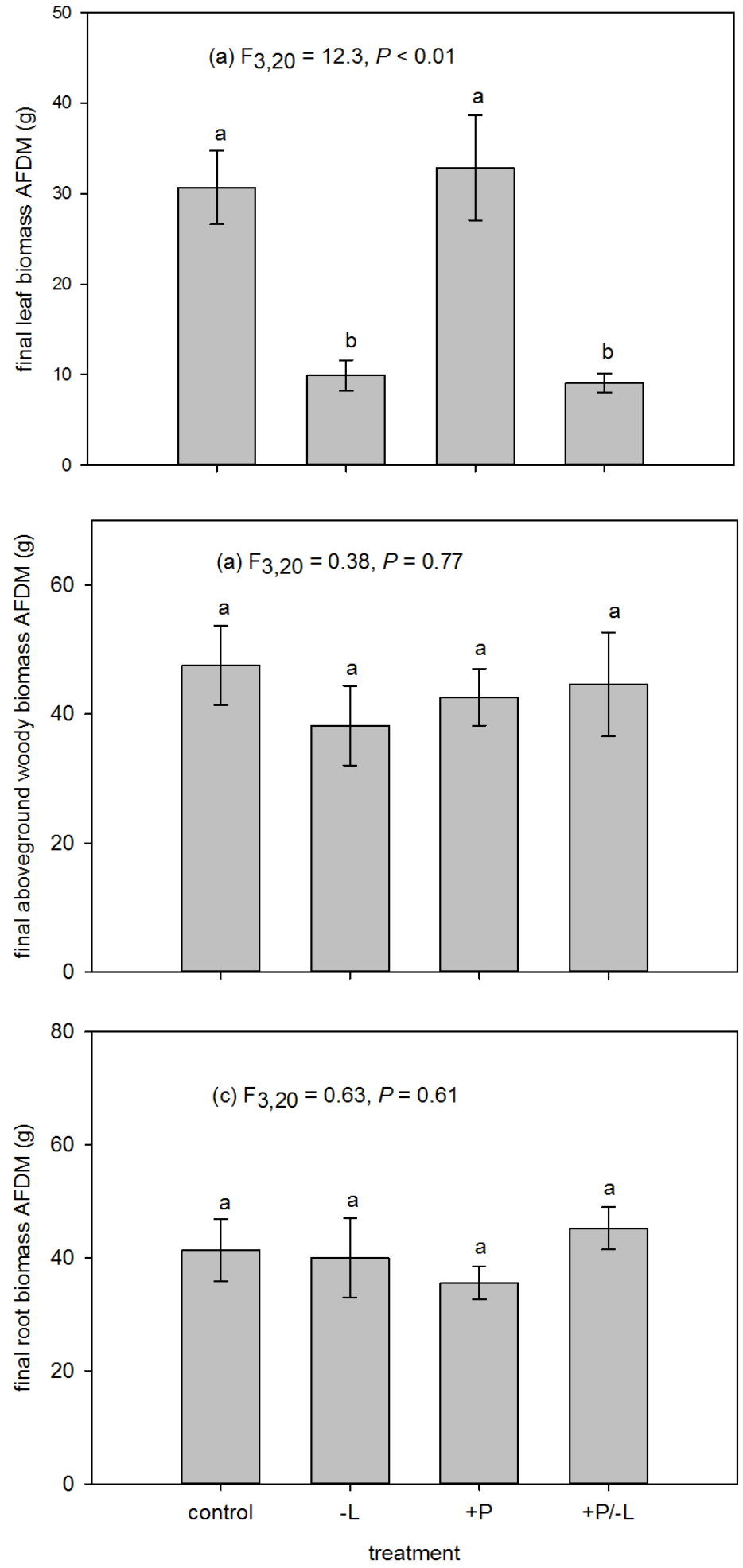
Figure 4.
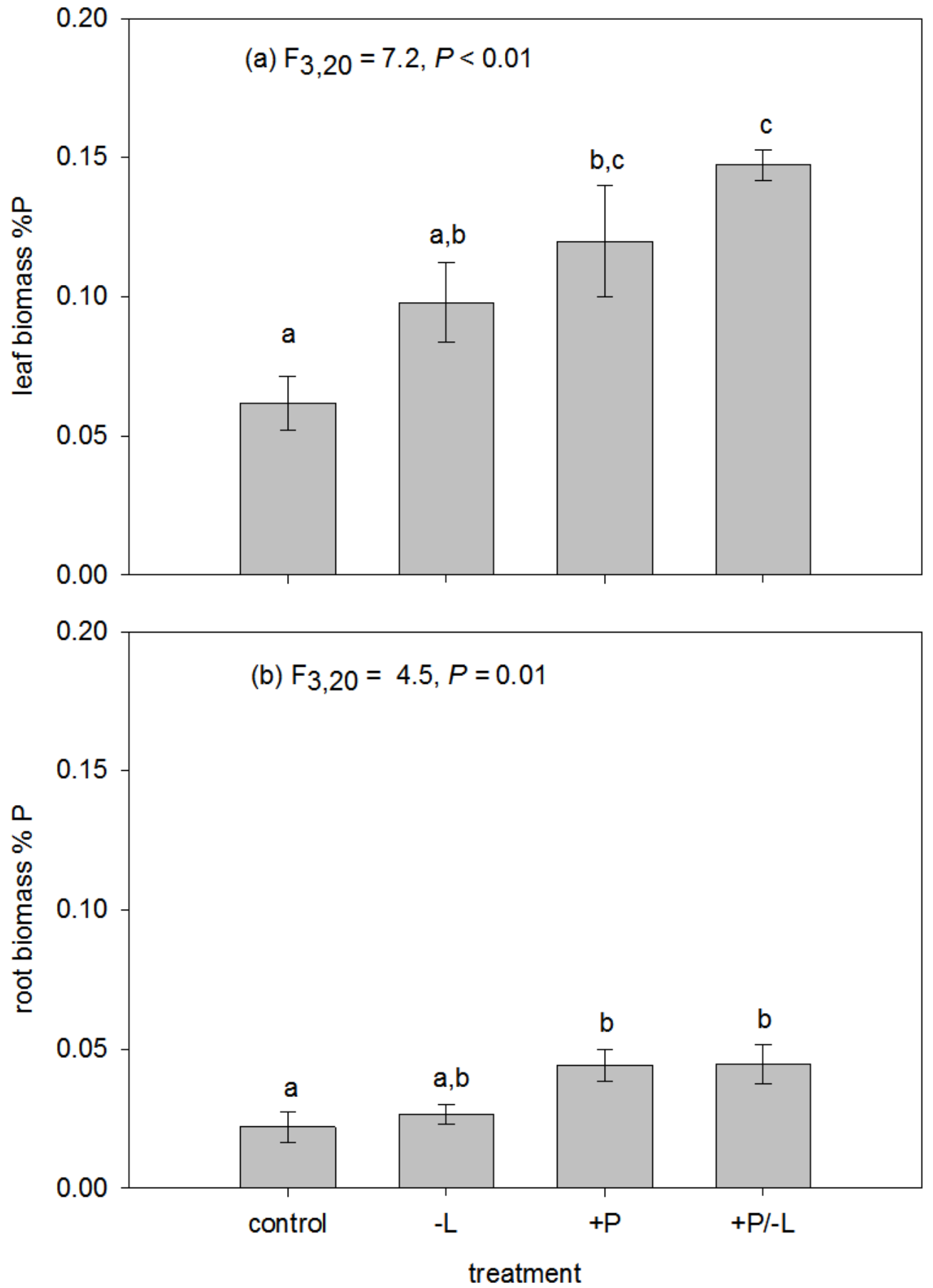
Figure 5.
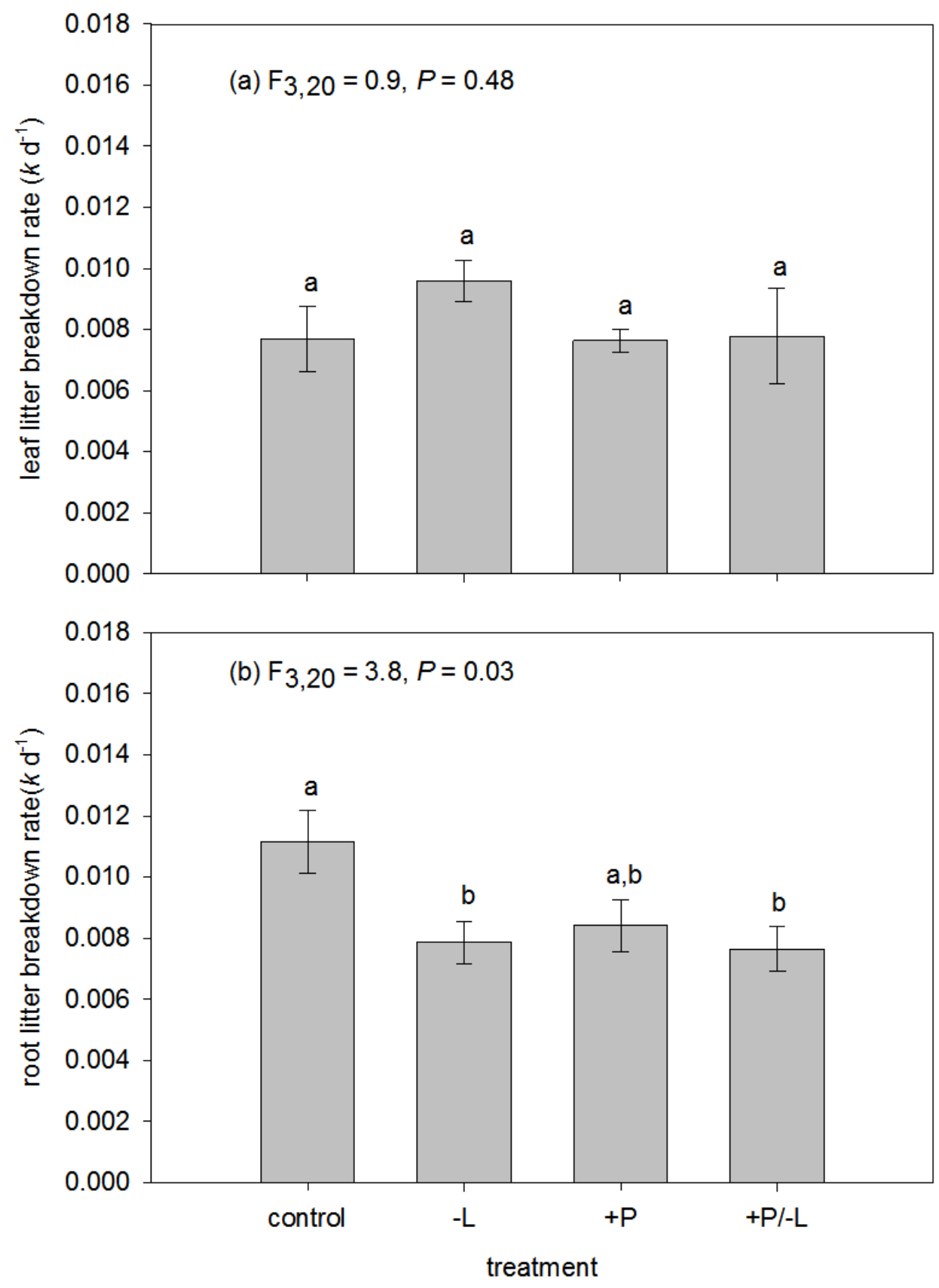
Figure 6.

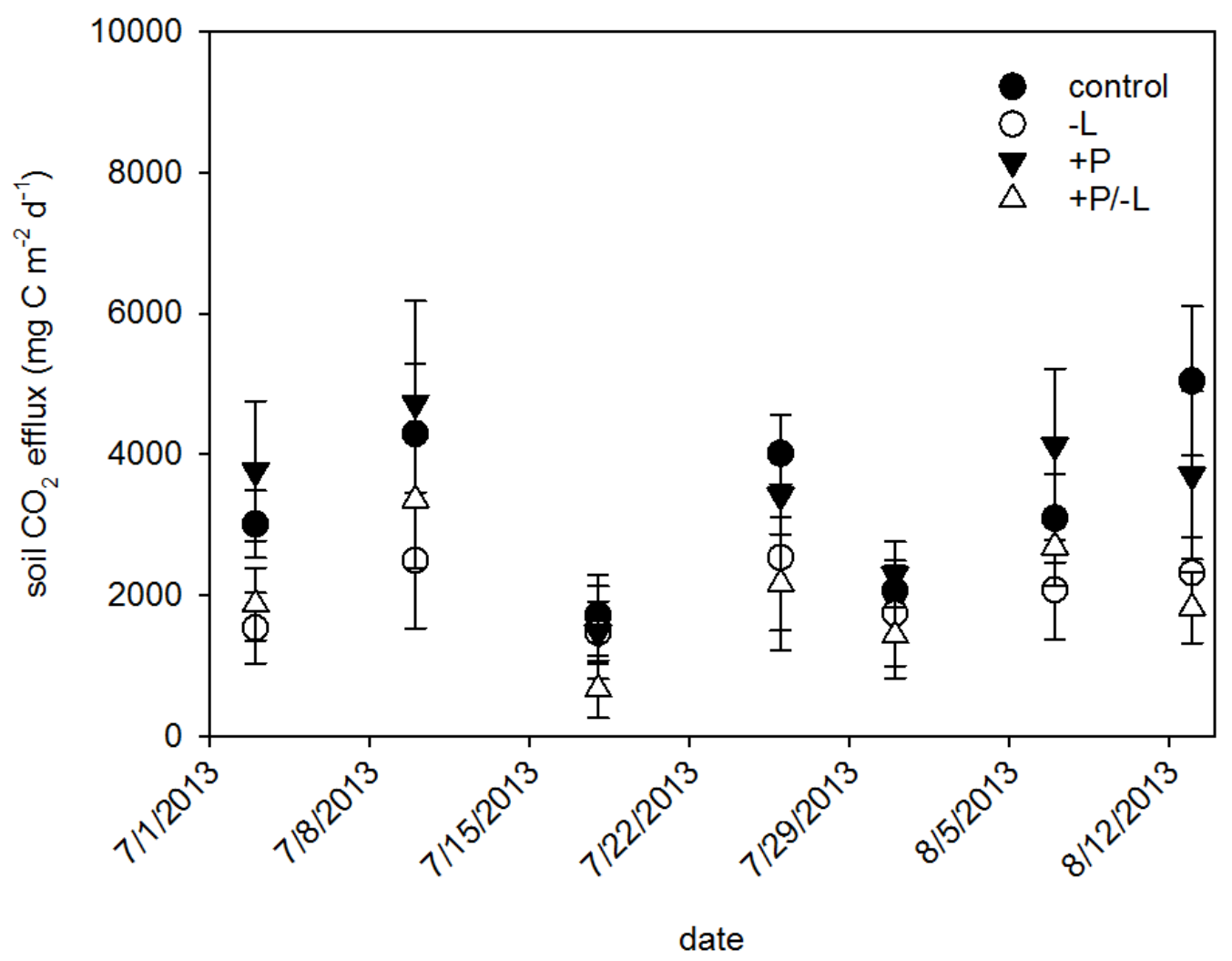


Figure 7.
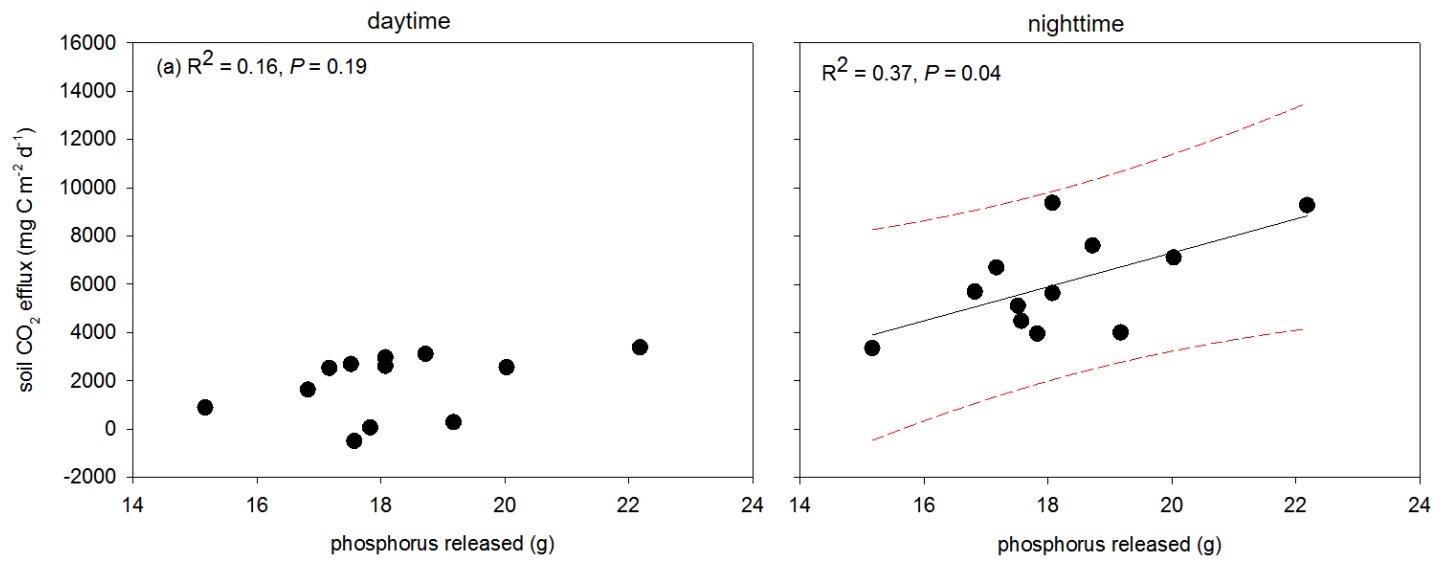


\section{SUPPLEMENTAL INFORMATION}

Table S1. Average ( \pm 1Standard Error) nutrient concentrations in surface water and soil porewater, and soil gas efflux measures collected from July 2 - August 13, 2013, from control and treatment experimental mangrove mesocosms. Units for parameters are for surface water and pore water, ug $\mathrm{L}^{-1}$, for $\mathrm{CO}_{2}-\mathrm{C}$ efflux, $\mathrm{mg} \mathrm{C} \mathrm{m} \mathrm{m}^{-2} \mathrm{~d}^{-1}$. Data associated with water chemistry and soil gas efflux were compared using a two-way ANOVA (with sample date as a variable) and Tukey's HSD. Significant model main effects and interaction terms are reported in the last column. "NS" indicates not significant $(P>$ 0.05). "BDL" indicates the sample was below detection limit. Numerical values are means 


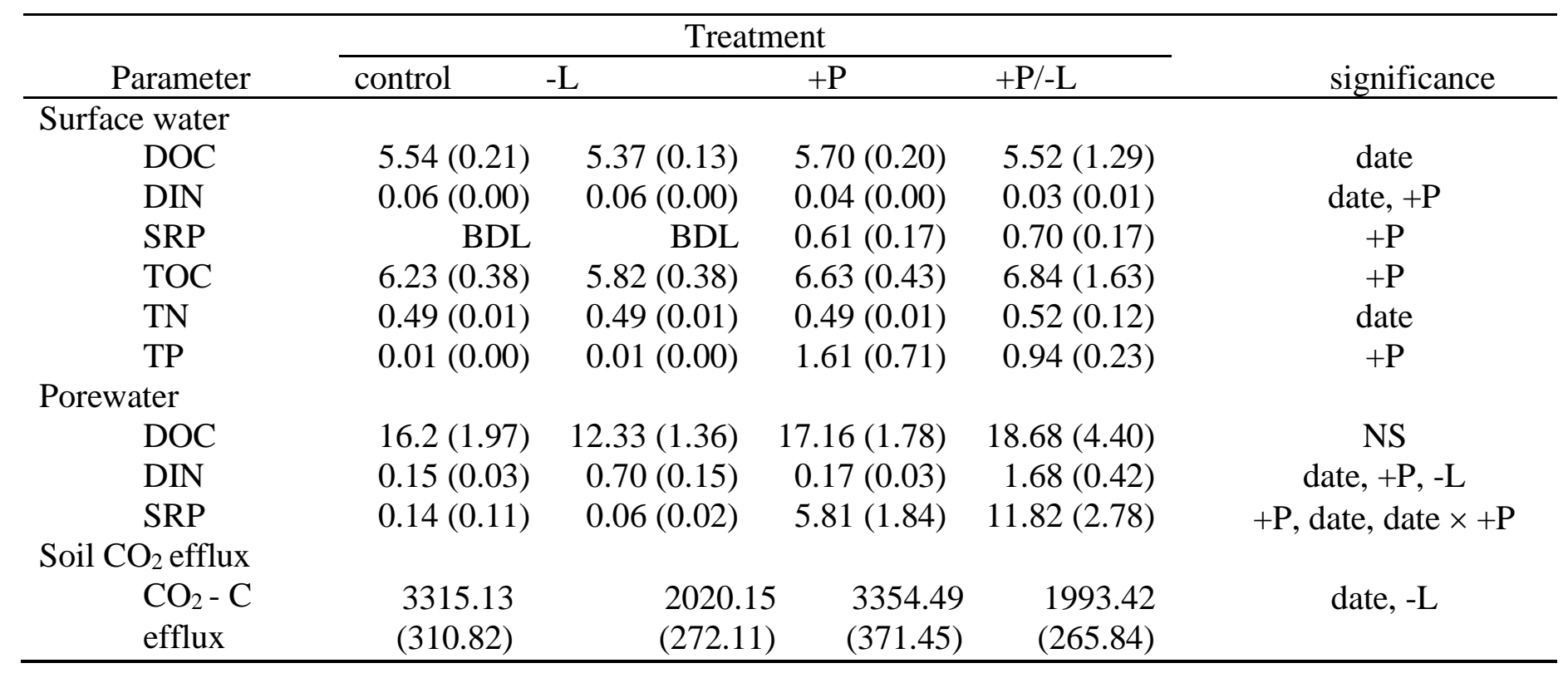


Table S2. Average ( \pm 1 Standard Error) percentage of carbon $(\mathrm{C})$, nitrogen $(\mathrm{N})$, and phosphorus $(\mathrm{P})$ of decomposing leaf and root litter, bulk soil, and live leaf and root biomass from control, defoliation (-L), $\mathrm{P}$ addition $(+\mathrm{P})$, and $-\mathrm{L} /+\mathrm{P}$ treatments. Mean values from the end of the experiment were compared using a two-way ANOVA and Tukey's HSD. Significant model main effects and interaction terms are reported in the last column. "NS" indicates not significant $(P>0.05)$. Numerical values are means. 


\begin{tabular}{crrrrr}
\hline \multicolumn{5}{c}{ Treatment } \\
\hline Parameter & control & $\begin{array}{c}\text { defoliation } \\
(-\mathrm{L})\end{array}$ & $\mathrm{P}$ & $+\mathrm{P} /-\mathrm{L}$ & significance \\
& & & & \\
\hline leaf litter & & & & \\
$\mathrm{C}$ & $51.81(5.68)$ & $49.39(2.56)$ & $45.09(1.99)$ & $46.54(4.89)$ & $\mathrm{NS}$ \\
$\mathrm{N}$ & $1.58(0.21)$ & $1.46(0.18)$ & $1.25(0.99)$ & $1.30(0.16)$ & $\mathrm{NS}$ \\
$\mathrm{P}$ & $0.06(0.00)$ & $0.06(0.01)$ & $0.06(0.00)$ & $0.07(0.00)$ & $\mathrm{NS}$ \\
root litter & & & & \\
$\mathrm{C}$ & $35.02(2.92)$ & $42.81(5.63)$ & $41.43(2.77)$ & $34.45(1.76)$ & $\mathrm{NS}$ \\
$\mathrm{N}$ & $0.58(0.05)$ & $0.63(0.08)$ & $0.63(0.10)$ & $0.48(0.04)$ & $\mathrm{NS}$ \\
$\mathrm{P}$ & $0.02(0.01)$ & $0.02(0.00)$ & $0.03(0.01)$ & $0.03(0.00)$ & $+\mathrm{P}$ \\
bulk soil (0-2 cm) & & & & & \\
$\mathrm{C}$ & $31.25(2.25)$ & $23.48(1.34)$ & $29.29(2.98)$ & $22.47(0.63)$ & $\mathrm{NS}$ \\
$\mathrm{N}$ & $1.77(0.09)$ & $1.36(0.13)$ & $1.81(0.21)$ & $1.36(0.11)$ & $\mathrm{NS}$ \\
$\mathrm{P}$ & $0.08(0.01)$ & $0.06(0.01)$ & $0.08(0.02)$ & $0.09(0.00)$ & $\mathrm{NS}$ \\
bulk soil (2-10 cm) & & & & & \\
$\mathrm{C}$ & $31.92(2.85)$ & $23.54(0.94)$ & $29.10(1.87)$ & $23.85(0.59)$ & $\mathrm{NS}$ \\
$\mathrm{N}$ & $2.04(0.22)$ & $1.41(0.16)$ & $1.75(0.16)$ & $1.38(0.03)$ & $\mathrm{NS}$ \\
$\mathrm{P}$ & $0.04(0.00)$ & $0.07(0.01)$ & $0.08(0.02)$ & $0.05(0.01)$ & $\mathrm{NS}$ \\
bulk soil (10-20 cm) & & & & & \\
$\mathrm{C}$ & $25.43(1.01)$ & $25.58(0.27)$ & $25.72(0.82)$ & $26.05(0.30)$ & $\mathrm{NS}$ \\
$\mathrm{N}$ & $1.63(0.12)$ & $1.70(0.04)$ & $1.54(0.10)$ & $1.68(0.06)$ & $\mathrm{NS}$ \\
$\mathrm{P}$ & $0.09(0.01)$ & $0.11(0.01)$ & $0.09(0.02)$ & $0.11(0.01)$ & $\mathrm{NS}$ \\
live leaf biomass & & & & & \\
$\mathrm{C}$ & $57.89(2.69)$ & $51.56(3.96)$ & $48.08(3.75)$ & $52.50(4.33)$ & $\mathrm{NS}$ \\
$\mathrm{N}$ & $2.04(0.26)$ & $1.96(0.33)$ & $2.06(0.15)$ & $1.94(0.25)$ & $\mathrm{NS}$ \\
$\mathrm{P}$ & $0.06(0.01)$ & $0.10(0.01)$ & $0.12(0.02)$ & $0.15(0.01)$ & $+\mathrm{P}$ \\
live root biomass & & & & \\
$\mathrm{C}$ & $41.11(3.18)$ & $40.91(3.15)$ & $39.34(0.37)$ & $42.30(4.06)$ & $\mathrm{NS}$ \\
$\mathrm{N}$ & $1.17(0.11)$ & $0.97(0.08)$ & $0.75(0.11)$ & $0.90(0.10)$ & $\mathrm{NS}$ \\
$\mathrm{P}$ & $0.02(0.01)$ & $0.03(0.00)$ & $0.04(0.01)$ & $0.04(0.01)$ & $+\mathrm{P}$ \\
\hline & & & &
\end{tabular}


Table S3. Average ( \pm Standard Error) molar ratio of carbon:nitrogen $(\mathrm{C}: \mathrm{N})$, C:phosphorus $(\mathrm{C}: \mathrm{P})$, and N:P of decomposing leaf and root litter, bulk soil, and life leaf and root biomass from control, defoliation (-L), $\mathrm{P}$ addition $(+\mathrm{P})$ and $-\mathrm{L} /+\mathrm{P}$ treatments. Mean values from the end of the experiment were compared using a two-way ANOVA and Tukey's HSD. Significant model main effects and interaction terms are reported in the last column. "NS" indicates not significant $(P>$ 0.05). Numerical values are means. 


\begin{tabular}{|c|c|c|c|c|c|c|}
\hline \multicolumn{7}{|c|}{ treatment } \\
\hline \multicolumn{2}{|c|}{ parameter } & control & $\begin{array}{c}\text { defoliation } \\
(-\mathrm{L})\end{array}$ & $\mathrm{P}$ & $+\mathrm{P} / \mathrm{L}$ & significance \\
\hline \multicolumn{7}{|l|}{ litter } \\
\hline & $\mathrm{C}: \mathrm{N}$ & $39.41(3.01)$ & $41.52(4.08)$ & 39.58 (3.04) & $46.46(2.92)$ & $+\mathrm{P}$ \\
\hline & $\mathrm{C}: \mathrm{P}$ & $2422.6(270.2)$ & $2312.6(237.6)$ & $1875.4(151.8)$ & $1875.9(129.2)$ & $+\mathrm{P}$ \\
\hline & $\mathrm{N}: \mathrm{P}$ & $63.24(8.59)$ & $57.50(5.95)$ & $47.90(3.72)$ & $41.45(4.37)$ & $+\mathrm{P}$ \\
\hline \multicolumn{7}{|l|}{ root } \\
\hline & $\mathrm{C}: \mathrm{N}$ & $73.18(7.78)$ & $81.37(7.82)$ & $86.34(7.22)$ & $81.57(6.66)$ & NS \\
\hline & $\mathrm{C}: \mathrm{P}$ & $5113.6(1181.2)$ & $4822.9(928.8)$ & $3624.2(746.6)$ & $3278.0(855.0)$ & NS \\
\hline & $\mathrm{N}: \mathrm{P}$ & $66.39(10.55)$ & $60.55(10.51)$ & $48.03(16.27)$ & $42.78(13.19)$ & NS \\
\hline \multirow{2}{*}{\multicolumn{7}{|c|}{$\begin{array}{l}\text { soil } \\
0-2 \mathrm{~cm}\end{array}$}} \\
\hline & & & & & & \\
\hline & $\mathrm{C}: \mathrm{N}$ & $20.54(0.65)$ & $20.39(1.36)$ & $18.98(0.39)$ & $19.55(1.76)$ & NS \\
\hline & $\mathrm{C}: \mathrm{P}$ & $1191.4(285.2)$ & $1165.1(324.8)$ & $1236.6(504.2)$ & $663.6(28.16)$ & NS \\
\hline & $\mathrm{N}: \mathrm{P}$ & $26.08(5.98)$ & $25.44(5.50)$ & $29.48(11.95)$ & $15.52(2.05)$ & NS \\
\hline \multicolumn{7}{|c|}{$2-10 \mathrm{~cm}$} \\
\hline & $\mathrm{C}: \mathrm{N}$ & $18.50(0.58)$ & $19.97(2.61)$ & $19.76(1.37)$ & $20.13(0.18)$ & NS \\
\hline & $\mathrm{C}: \mathrm{P}$ & $2018.8(366.3)$ & $874.3(184.1)$ & $1201.1(518.4)$ & $1359.9(570.3)$ & NS \\
\hline & $\mathrm{N}: \mathrm{P}$ & $50.04(9.86)$ & $19.57(1.62$ & $27.28(11.24)$ & $30.40(0.71)$ & NS \\
\hline \multicolumn{7}{|c|}{$10-20 \mathrm{~cm}$} \\
\hline & $\mathrm{C}: \mathrm{N}$ & $18.71(1.82)$ & $17.60(0.50)$ & 19.69 (1.07) & $18.14(0.71)$ & NS \\
\hline & $\mathrm{C}: \mathrm{P}$ & $776.6(141.3)$ & 620.6 (89.6) & 819.9 (198.2) & $642.4(54.67)$ & NS \\
\hline & $\mathrm{N}: \mathrm{P}$ & $18.95(2.97)$ & $16.01(2.75)$ & $18.41(3.49)$ & $15.97(0.74)$ & NS \\
\hline \multicolumn{7}{|c|}{$\begin{array}{l}\text { live biomass } \\
\text { leaves }\end{array}$} \\
\hline & $\mathrm{C}: \mathrm{N}$ & $36.48(5.46)$ & $35.76(16.15)$ & $27.40(3.63)$ & $32.85(6.19))$ & $+\mathrm{P}$ \\
\hline & $\mathrm{C}: \mathrm{P}$ & $2673.6(332.5)$ & $1624.2(951.2)$ & $1182.3(494.8)$ & $922.9(183.7)$ & $+\mathrm{P},+\mathrm{P} \times-\mathrm{L}$ \\
\hline & $\mathrm{N}: \mathrm{P}$ & $76.70(10.26)$ & $49.71(24.43)$ & $43.20(16.65)$ & $28.92(7.59)$ & $+\mathrm{P},+\mathrm{P} \times-\mathrm{L}$ \\
\hline \multicolumn{3}{|l|}{ roots } & $49.37(7.39)$ & $70.38(34.51)$ & $56.36(15.02)$ & $+\mathrm{P}$ \\
\hline & $\mathrm{C}: \mathrm{P}$ & $5802.1(1013.1)$ & $4435.7(1734.9)$ & $2463.7(738.3)$ & $2671.5(944.0)$ & $+\mathrm{P}$ \\
\hline & $\mathrm{N}: \mathrm{P}$ & $135.03(16.89)$ & $89.03(30.86)$ & $41.5723 .80)$ & $50.04(24.61)$ & $+\mathrm{P},+\mathrm{P} \times-\mathrm{L}$ \\
\hline
\end{tabular}


CHAPTER II

QUANTIFYING MICROBIALLY-MEDIATED SOIL CARBON LOSS FROM SALTWATER INTRUSION INTO FRESHWATER WETLANDS: EXPERIMENTAL TESTS OF ELEVATED SALINITY AND PHOSPHORUS 
Title: Quantifying microbially-mediated soil carbon loss from saltwater intrusion into freshwater wetlands: experimental tests of elevated salinity and phosphorus

\author{
Shelby Servais ${ }^{1 *}$, John S. Kominoski ${ }^{1}$, Sean P. Charles ${ }^{1}$, Evelyn E. Gaiser ${ }^{1}$, Viviana \\ Mazzei $^{1}$, Tiffany G. Troxler ${ }^{1,2}$, Benjamin J. Wilson ${ }^{1}$ \\ ${ }^{1}$ Department of Biological Sciences and Southeast Environmental Research Center, \\ Florida International University, Miami, Florida 33199 USA \\ ${ }^{2}$ Sea Level Solutions Center, Florida International University
}

*Email: sserv005@fiu.edu, Phone: (410) 8523720

\begin{abstract}
Wetlands have the capacity to store significant amounts of carbon (C), but climate and land-use change increasingly threaten wetland $\mathrm{C}$ storage potential. Carbon stored in soils of freshwater coastal wetlands is vulnerable to saltwater intrusion (SWI) associated with sea level rise. In the Florida Everglades, SWI is simultaneously exposing wetlands soils to elevated salinity and phosphorus $(\mathrm{P})$, in areas where $\mathrm{C}$-rich peat soils are collapsing. To determine how salinity and $\mathrm{P}$ interact to influence microbial contributions to $\mathrm{C}$ loss, we conducted an experimental manipulation in wetland mesocosms. We continuously added $\mathrm{P}\left(\sim 0.5 \mathrm{mg} \mathrm{P} \mathrm{d}^{-1}\right)$ and salinity $\left(\sim 6.9 \mathrm{~g} \mathrm{salt}^{-1}\right)$ to freshwater Cladium
\end{abstract}


jamaicense (sawgrass) peat monoliths for two years using a $2 \times 2$ factorial design. We measured changes in surface water chemistry, porewater chemistry, microbial extracellular enzyme activities, respiration rates, microbial biomass, root litter breakdown, and soil elemental composition after short (57-d) intermediate- (392-d) and long-term (741-d) exposure. Surface water total and dissolved organic C increased by $1.5 \times$ after long-term exposure to salinity. After 741 days, both $\beta$-1,4-glucosidase activity $(P<0.01)$ and $\beta$-1,4-cellobiosidase activity $(P<0.01)$ were reduced with added salinity in the deeper soils. Soil microbial biomass decreased by $3.6 \times$ within deeper $(P<0.01)$ but not surface soils $(P>0.05)$. Soil respiration rates only decreased after 372 -d with salinity $(P=0.05)$ but were not sensitive to $\mathrm{P}$ exposure. Root litter $k$ increased by $1.5 \times$ with added $\mathrm{P}$ and was unaffected by salinity exposure $(P>0.01)$. Soil $\mathrm{C}$ decreased by $1.1 \times$ after 741 days of salinity exposure $(P<0.01)$. Despite significant overall reductions in microbial activities, elevated salinity and $\mathrm{P}$ accelerated wetland soil $\mathrm{C}$ loss through leaching of TOC and increased root litter $k$. Our results indicate that freshwater wetland soils are highly sensitive to SWI, leading to C loss after both short- and long-term exposure.

Keywords: microbial extracellular enzymes, wetlands, peat collapse, sea-level rise, Everglades 


\section{INTRODUCTION}

Coastal wetlands are critical carbon $(\mathrm{C})$ reservoirs and store disproportionate amounts of $\mathrm{C}$ relative to the total land area, with some capable of storing up to 50 times more $\mathrm{C}$ than tropical forests (Bouillon 2011; Mcleod et al. 2011). External stressors associated with climate change have the potential to degrade wetlands and drastically alter ecosystem function (Green et al. 2017). Coastal freshwater wetlands occupy a vulnerable position at the interface of terrestrial and marine environments and are increasingly exposed to saltwater intrusion (SWI; White and Kaplan 2017). Saltwater intrusion poses a particular threat to wetland carbon (C) storage, a globally important ecosystem service driven by historical and current environmental conditions that have promoted carbon dioxide $\left(\mathrm{CO}_{2}\right)$ uptake and its sequestration as organic $\mathrm{C}$ within the soil and plant biomass. Exposure of coastal freshwater marshes to SWI affects the biogeochemical cycles that support $\mathrm{C}$ storage and can potentially cause these systems to transition from net sinks to net sources (Weston et al. 2011).

Changing environmental conditions associated with salinity affect microbial processing and consequently the rate of C cycling (Weston et al. 2006). Anaerobic conditions in water-logged systems slow biogeochemical processing rates and organic matter decomposition which promotes C storage (Helton et al. 2015). Increases in salinity can change redox potential (Rietz and Haynes 2003; Van Riyckegem and Verbeken 2005), electron acceptor availability (Helton et al. 2015), osmotic stress, and organic substrate quantity and quality (Neubauer 2013). Saltwater intrusion can increase microbial respiration, stimulating organic $\mathrm{C}$ loss from wetland soils. The effects of salinity on microbe-mediated biogeochemical processes can occur within short time 
periods (Craft 2007, Weston et al. 2010, Weston et al. 2006, Neubauer 2013, Chambers et al. 2014). Even moderate salinity increases (3-15 ppt) can affect the physiochemical characteristics of freshwater wetland soils (Rysgaard et al. 1999; Berner and Berner 2012; Flower et al. 2017) and cause microbial communities to shift from dominance by freshwater to marine-adapted species (Casamayor et al. 2012).

Land and water management and climate change pressures contribute to SWI and simultaneously alter multiple environmental conditions that interact to elicit ecosystem responses (Green et al. 2017). For example, karstic freshwater wetlands found in the Florida Everglades and throughout the Caribbean are extremely limited by phosphorus (P) and often receive most of the limiting nutrient from marine water inputs (Fourqurean et al. 1993; Boyer et al. 1999; Noe et al. 2001; Childers et al. 2006). When saltwater infiltrates the porous limestone bedrock of the Everglades, the P adsorbed to calcium carbonate is released into the water (Price et al. 2006; Price et al. 2010; Flower et al. 2017). In the vulnerable wetlands of the Everglades, SWI represents both a stress caused by elevated salinity and a resource subsidy in the form of $\mathrm{P}$ inputs, but the combined effects of salinity and $\mathrm{P}$ on microbial activity are unknown. However, recent observations of peat collapse, a term used to describe rapid soil subsidence, has been observed within the Everglades. By altering soil microbial processing rates and plant productivity SWI into previously freshwater wetlands is hypothesized to increase soil susceptibility to collapse.

Soil microbes are often considered the first responders to changing environmental conditions because of their large surface area to volume ratio, permeable membrane, and rapid turnover rates. In addition, soil microbes drive $\mathrm{C}$ and nutrient cycling within soils 
(Penton and Newman 2007). Assessing how soil microbe function is altered with salinity and $\mathrm{P}$ is essential to our understanding of how SWI will affect coastal wetland C storage. Extracellular enzymes are an important driver of microbe-mediated biogeochemical cycling, and enzyme-catalyzed biochemical reactions are often considered the ratelimiting step in organic matter degradation (Chrost and Rai 1993; Dick 1994). When microbes are limited by bioavailable $\mathrm{C}$ or nutrients, they release extracellular enzymes into soils to meet metabolic demands. Therefore, measurements of extracellular enzymes can provide information on the quality of organic soils, nutrient cycling, and microbial elemental demand (Sinsabaugh et al. 2002). Enzyme activities are often suppressed when exposed to saline conditions (Frankenberger and Bingham 1982; Jackson and Vallaire 2009), as microbes divert resources to the production of osmolytes and consequentially reduce production of extracellular enzymes (Kempf and Bremer 1998). In contrast, $\mathrm{P}$ enrichment studies find an inverse relationship with phosphatase enzyme activities (Speiers and McGill 1979; Wright and Reddy 2001; Morrison et al. 2016) and positive relationships with other enzymes activities (Rejmánková and Sirova 2007). The effects of simultaneous exposure to osmotic stress and increased availability of limiting nutrients on microbial function and the evolution of microbial responses over time are unknown despite the importance of soil microbes in determining ecosystem C storage potential. In the Everglades, and other coastal freshwater wetlands with organic-rich soils, changes in extracellular enzyme activities may lead to long term-effects on collapse and accumulation of C-storing peat soils (Penton and Newman 2007).

The interactive effects of salinity stress and nutrient subsidies on soil microbial functions are critical mechanistic pathways that may help unravel the C-cycling 
responses of coastal freshwater wetlands to SWI. We used P-limited, freshwater peat soils from the Florida Everglades to test how microbial extracellular enzyme activity, soil elemental stoichiometry, root litter $k$, and surface and porewater chemistry responded to continuous exposure to elevated salinity and $\mathrm{P}$ to collectively effect net soil carbon storage. We hypothesized that (1) elevated salinity would cause increases in C and nutrients in the surface and porewater and become available to soil microbes for metabolism; (2) elevated salinity would cause microbial communities to invest resources in maintaining cell turgor and consequentially have fewer resources devoted to the production of all types of extracellular enzymes than ambient salinity conditions.(Table 1); (3) the greatest effects of salinity would occur during early exposure as the microbial community transitioned from a freshwater community to a salt-adapted community; (4) P addition would increase potential activity for C- and sulfur (S)- acquiring enzymes and decrease in potential activity for $\mathrm{P}$-acquiring enzymes because the release from $\mathrm{P}$ limitation would increase $\mathrm{C}$ and other nutrient demands while lowering $\mathrm{P}$ demands (Table 1); (5) salinity and $P$ would interact to decrease $P$ and S- acquiring enzymes and result in similar activity levels of C-acquiring enzymes relative to the freshwater control; (6) soil microbial respiration rates would be highest in the salinity and $\mathrm{P}$ combination treatment as the combination of stress and subsidy interact to increase soil microbial respiration; (7) the greatest changes in microbial function would be observed in the more active surficial soil, however, we expected to see similar effects of salinity and P at both soil depths. Understanding how microbial functions changes with salinity exposure and nutrient enrichment is increasingly important as coastal environments become more exposed to SWI. 


\section{MATERIALS AND METHODS}

\section{Study area and experimental wetland facility}

We collected twenty-four sawgrass-peat cores from a freshwater wetland in the Florida Everglades ( $\left.25^{\circ} 46^{\prime} 06.1^{\prime \prime} \mathrm{N} 80^{\circ} 28^{\prime} 56.2^{\prime \prime W}\right)$ in July 2014 . We removed the plantsoil monoliths using shovels to excise the marsh and trimmed the excess soil and roots to fit within each mesh lined containers $(0.3 \mathrm{~m} \mathrm{D} \times 0.4 \mathrm{~m} \mathrm{~W} \times 0.5 \mathrm{~m} \mathrm{~L})$. Monoliths were transported to the Florida Bay Interagency Science Center Mesocosm Facility in Key Largo, FL USA, and placed into sealed polycarbonate containers $(0.5 \mathrm{~m} \mathrm{D} \times 0.5 \mathrm{~m} \mathrm{~W} \times$ $0.7 \mathrm{~m} \mathrm{~L}$ ). We randomly assigned each plant-soil monolith to one of six concrete mesocosm tanks $(0.7 \mathrm{~m} \mathrm{D} \times 0.8 \mathrm{~m} \mathrm{~W} \times 2.2 \mathrm{~m} \mathrm{~L})$ containing freshwater, similar to what is found in freshwater of the Everglades, from a nearby canal $\left(\mathrm{C}-111 ; 25^{\circ} 17^{\prime} 31.74^{\prime \prime} \mathrm{N}\right.$, $\left.80^{\circ} 27^{\prime} 21.59^{\prime \prime} \mathrm{W}\right)$. Each monolith was individually contained, and contamination between monoliths was prevented by spacing the bins within each concrete mesocosm. We allowed the monoliths to equilibrate for approximately 7 months before beginning experimental manipulation.

\section{Experimental design}

We used a $2 \times 2$ factorial design with two factors, salinity and $\mathrm{P}$, for a total of four treatments: (i) freshwater (fresh), (ii) fresh with P (fresh + P), (iii) salinity (salt), (iv) and salinity with $\mathrm{P}($ salt $+\mathrm{P})$. Each concrete mesocosm was designated as either fresh or salinity treatment, and two of the four sawgrass-peat monoliths in each tank received $\mathrm{P}$ while the other two did not. Phosphorus was continuously added to each P treatment monolith individually by delivering $2.25 \mathrm{mg} \mathrm{L}^{-1}$ diluted phosphoric acid at $0.14 \mathrm{~mL} \mathrm{~min}{ }^{-1}$ 
using two multichannel peristaltic pumps, with six lines each $(n=12$, Ismatec,

Weirtheim, Germany). Within each concrete mesocosm, two P-treated monoliths were separated from two non-P treatments using a plastic divider.

The freshwater treatment (fresh) consisted of twice-weekly manual additions of freshwater collected from C-111 to maintain submergence of the soil surface of each freshwater treated monolith. To achieve target salinity concentrations (7-10 ppt) for the salinity treatment, we mixed water from the freshwater treatment with seawater from a nearby site in Florida Bay. The salinity treatment consisted of twice-weekly manual additions of the saltwater mixture to maintain the submergence of the soil surface of each salinity treated monolith. Freshwater was added to the salinity cores starting in June of 2016 to prevent salinity treatment cores from becoming hypersaline through evaporation. The sources of freshwater and saltwater were used to replenish water within each bin to maintain water levels and to reach target salinity treatment conditions. In total, 84,933 \pm $1,717 \mathrm{~g} \mathrm{~m}^{-3}$ of salt was added to each salinity treated sawgrass-peat monolith and $6.17 \pm$ $0.01 \mathrm{~g} \mathrm{~m}^{-3}$ of $\mathrm{P}$ was added to each $\mathrm{P}$ treated sawgrass-peat monolith. Total $\mathrm{P}$ and salt loads were calculated by summing the monthly mean load of each constituent added to each sawgrass-peat monolith.

\section{Physicochemical conditions}

In each of the 24 individual containers housing the sawgrass-peat monoliths we measured water temperature, $\mathrm{pH}$, and salinity weekly using a YSI Model $600 \mathrm{XL}$ (Xylem, Inc., Yellow Springs, OH, USA) on the surface water surrounding each plantsoil monolith. We collected monthly surface water samples (filtered and unfiltered) and 
soil porewater (filtered) samples monthly from each plant-soil monolith $(\mathrm{n}=72)$.

Unfiltered surface water samples were collected in $60 \mathrm{~mL}$ HDPE sample bottles. Filtered surface water samples were collected in a plastic syringe and filtered onsite through a $0.7-\mu \mathrm{m}$ glass fiber filter (GF/F) into a $60 \mathrm{~mL}$ HDPE sample bottle. Porewater was collected from a sipper with an air stone installed through the center of each sawgrasspeat monolith at a depth of $15 \mathrm{~cm}$ from the soil surface. Porewater was filtered using a $0.7-\mu \mathrm{m} \mathrm{GF} / \mathrm{F}$ and transferred into a $60 \mathrm{~mL}$ HDPE sample bottle. All water samples were stored at $-20^{\circ} \mathrm{C}$ until analyzed at the Southeast Environmental Research Center, Nutrient Analysis Laboratory. Unfiltered surface water was analyzed for total N (TN), total P (TP), and total organic C (TOC). Filtered porewater and filtered surface water samples were analyzed for dissolved organic $\mathrm{C}(\mathrm{DOC})$, dissolved inorganic nitrogen (DIN, $\mathrm{NO}_{3}{ }^{-}$, $\mathrm{NO}_{2}^{-}, \mathrm{NH}_{4}^{+}$), and soluble reactive $\mathrm{P}(\mathrm{SRP})$. Dissolved inorganic $\mathrm{N}$, total N, TP and SRP parameters were analyzed on a Alpkem RFA 300 auto-analyzer (OI Analytical, College Station, TX, USA) and TOC and DOC were analyzed with a Shimadzu 5000 TOC Analyzer (Shimadzu Scientific Instruments, Columbia, MD, USA). Filtered and unfiltered grab samples were collected monthly from January 2016 to December 2016 within the freshwater and saltwater mixtures. The source water samples analyzed for TN, TP, TOC, DOC, DIN, $\mathrm{NO}_{3}{ }^{-}, \mathrm{NO}_{2}{ }^{-}, \mathrm{NH}_{4}{ }^{+}$and SRP following the same methods described above for water samples collected from each monolith.

We measured oxidation-reduction potential (hereafter redox) every other month (starting in June 2016) in each plant-soil monolith at approximately 15-cm depth, using platinum-tipped copper probes and a pH voltmeter (Faulkner et al. 1989). 


\section{Soil elemental composition}

We collected soil samples after 57, 392, and 741 days of exposure to treatment conditions to assess short-, intermediate-, and long-term responses. We implemented two approaches to measure bulk soil responses 1.) we deployed soil pouches in the water column after short-term exposure to treatment conditions and 2.) we collected soil cores after intermediate- and long-term exposure to treatment conditions. For the short-term soil pouches, to minimize destruction to the intact monoliths, we incubated surficial soil, collected from the same location as the monoliths, within $125-\mu \mathrm{m}$ mesh pouches. We incubated three replicate soil pouches within each treatment by suspending the soil pouch in the water column $(n=12)$. For the later collections, soil cores were taken from the sawgrass-peat monolith after 392 and 741-d of continuous exposure to the treatments (2 $\mathrm{cm}$ diameter $\times 15 \mathrm{~cm}$ depth) and sectioned into two depths $(0-7.5$ and $7.5-15 \mathrm{~cm}, \mathrm{n}=48)$. We dried all soil samples in an oven at $60^{\circ} \mathrm{C}$ for $48 \mathrm{~h}$. Ground soil material was subsampled, oven-dried $\left(60^{\circ} \mathrm{C}\right)$ for $48 \mathrm{~h}$, weighed, combusted $\left(550^{\circ} \mathrm{C}\right.$ for $\left.4 \mathrm{~h}\right)$, and reweighed to determine ash-free dry mass (AFDM). Carbon and $\mathrm{N}$ content were analyzed using a Carlo Erba NA 1500 CHN Analyser (Carlo Erba, Milan, Italy). Phosphorus content was analyzed using the ash/acid extraction method followed by spectrophotometric analysis using the ascorbic acid method (Allen 1974, APHA 1998). We estimated elemental composition $(\% \mathrm{C}, \% \mathrm{~N}$, and $\% \mathrm{P})$ in the $57-\mathrm{d}$ surficial soil and at two soil depths $(0-7.5 \mathrm{~cm}$ and $7.5-15 \mathrm{~cm})$ for the 392 and $741 \mathrm{~d}$ collections. All elemental compositions were calculated from the molar mass. 


\section{Soil extracellular enzyme activities}

On days 57, 392, and 741 of the experiment we measured the fluorometric activities of extracellular acid phosphatase, arylsulfatase, $\beta-1,4$-glucosidase, and $\beta-1,4-$ cellobiosidase from soil sub-samples. Using the substrates described in Table 1, soil microbial enzyme activities were assayed using previously described methods (SaiyaCork et al. 2002). Soil sub-samples were collected (approximately $1 \mathrm{~g}$ ) from each sawgrass-peat monolith, homogenized in $60 \mathrm{~mL}$ of $50 \mathrm{mM}$ sodium acetate buffer, and loaded onto a 96-well plate with the appropriate substrate (Table 1). Fluorescence was read at $365 \mathrm{~nm}$ excitation and $450 \mathrm{~nm}$ emission using a Synergy $\mathrm{H} 1$ microplate reader (BioTek, Winooski, Vermont, USA). We incorporated blanks and controls within each microplate to account for autofluorescence and quenching.

\section{Soil microbial respiration rates and biomass carbon}

We measured microbial respiration in soil samples harvested at 57-d and from the two soil depths on 392 and 741-d collections. Approximately $2.5 \mathrm{~g}$ of weighed wet soils were placed in respiration chambers $(60 \mathrm{~mL})$ within $2 \mathrm{~h}$ of retrieval. The chambers were filled to capacity with either the freshwater or saltwater sources depending on the sample's assigned treatment to remove headspace and incubated at room temperature (24 ${ }^{\circ} \mathrm{C}$ ) for 2 hours. Chambers filled only with the source water served as blanks. Oxygen concentrations were measured at the start and end of the incubation period to determine the rate of oxygen consumption. Soil respiration was determined by subtracting the change in oxygen concentrations in control chambers from the change in oxygen consumption in the samples to account for respiration in the water. 
To estimate the mass of the living microorganisms within the soil, we determined the microbial biomass $\mathrm{C}$ from cores collected at the two soil depths on the 392 and $741 \mathrm{~d}$ collections using chloroform fumigation and potassium sulfate extraction methods following Vance et al. (1987). Soil microbial biomass C was only measured after intermediate- and long-term exposure because we expected changes in microbial biomass to be integrated over time. Dissolved organic C samples were analyzed with a Shimadzu 5000 TOC Analyzer (Shimadzu Scientific Instruments, Columbia, MD, USA). We calculated microbial biomass $\mathrm{C}$ as the difference in DOC between non-fumigated and fumigated samples.

\section{Root litter breakdown}

Within each sawgrass-peat monolith, nylon mesh $(1 \mathrm{~mm})$ root litter bags $(10 \mathrm{~cm}$ $\mathrm{W} \times 15 \mathrm{~cm} \mathrm{~L})$ were deployed at two depths $(0-7.5$ and $7.5-15 \mathrm{~cm})$ separated into two compartments at each depth. We used one compartment to determine mass loss and the second compartment to determine enzyme activities. Each compartment $(n=4)$ was filled with dried sawgrass root material of known, constant mass $(0.954 \pm 0.005 \mathrm{~g})$. We retrieved all liter bags after $361 \mathrm{~d}$ of incubation to quantify mass loss. We estimated the proportion of mass loss within each litter bag by rinsing sediments from remaining litter material, drying it to a constant mass, and calculating the proportion of mass that was lost over the 361-d incubation. We estimated breakdown rate, $k$, by first transforming by the natural $\log$ the proportion of AFDM remaining. We then produced a linear regression of the ln-transformed data versus time (Benfield 2006). The model was $M_{361}=M_{0} \times e^{-k 361}$, where $\mathrm{M}_{0}$ is the initial litter mass on day $0, \mathrm{M}_{361}$ is the litter mass on day 361 . We also 
calculated enzyme activities for phosphatase, arylsulfatase, $\beta$-1,4-glucosidase, and $\beta$-1,4cellobiosidase enzymes using the same method described for soil enzyme activities.

\section{Data analysis}

The constituents (TN, TP, TOC, DOC, DIN, $\mathrm{NO}_{3}{ }^{-}, \mathrm{NO}_{2}{ }^{-}, \mathrm{NH}_{4}{ }^{+}$and SRP) of the fresh and salinity source water added to the monoliths were compared using a student's ttest. We ran two-way analysis of variance (ANOVA) to test effects of salinity and P addition on soil elemental composition and differences (delta) in surface and porewater constituents (TN, TP, TOC, DOC, DIN, $\mathrm{NO}_{3}{ }^{-}, \mathrm{NO}_{2}{ }^{-}, \mathrm{NH}_{4}{ }^{+}, \mathrm{SRP}$ salinity and $\mathrm{pH}$ ) between initial water samples and water samples at 57-d, between water samples at 57 and 392-d, and between 392 and 741-d.

We used a two-way ANOVA followed by a Tukey HSD test to determine differences in average enzyme activity, root litter breakdown, and enzyme breakdown efficiency among treatments at 57, 392, and 741 days. We considered results with an alpha less than 0.05 statistically significant. We performed all statistical analyses using $\mathrm{R}$ Studio (R Core Team 2016).

\section{RESULTS}

\subsection{Physicochemical conditions}

In the surface water, delta TOC was negative and lower in the salt $+\mathrm{P}$ treatment at $57-\mathrm{d}(F=7.14 ; P=0.01)$, positive and higher in the salinity $(F=113.69 ; P<0.01)$ and salt $+\mathrm{P}$ treatments $(F=10.87 ; P<0.01)$, with an interaction increasing delta TOC between salinity and P between at 392-d, and positive and significantly higher in the 
salinity treatment between 392 and 741-d $(F=11.25 ; P<0.01$, Table 2$)$. Surface water delta DOC was not different among treatments at 57-d, increased in the salinity treatment at 392-d $(F=57.28 ; P<0.01)$, and not different among treatments at 741-d (Table 2). Surface water delta TN was lower with $\mathrm{P}$ addition $(F=11.87 ; P<0.01)$ and salinity and P interacted to lower TN $(F=9.35 ; P<0.01)$ at $57-$ d. At $392-$ d, surface water delta TN was negative and lower with $\mathrm{P}(F=7.2 ; P=0.01)$, positive and higher with salinity $(F=$ 61.55; $P<0.01)$ and increased with salinity and $\mathrm{P}$ interaction $(F=10.24 ; P<0.01)$. At 741 days, surface water delta TN was positive and higher with salinity at 741-d $(F=$ 16.60; $P<0.01$, Table 2). Surface water delta TP was higher with $\mathrm{P}$ at $57-\mathrm{d}(F=10.16 ; P$ $<0.01)$, higher with salinity at 392-d $(F=5.34 ; P=0.03)$, and not different among treatments at 741-d (Table 2). Surface water delta $\mathrm{NO}_{3}{ }^{-}$was lower with $\mathrm{P}$ at $57-\mathrm{d}(\mathrm{F}=$ 4.55; $P=0.05)$, was increased by a salinity and $\mathrm{P}$ interaction at $392-\mathrm{d}(F=7.03 ; P=$ 0.02), and was not different among treatments at 741-d (Table 2). Surface water delta $\mathrm{NO}_{2}^{-}$was not different among treatments at 57-d nor 392-d but, was higher in the salinity and salt $+\mathrm{P}$ treatments at $741-\mathrm{d}(F=8.07 ; P=0.01$, Table 2$)$. Surface water delta DIN was lower in the fresh $+\mathrm{P}$ and salt $+\mathrm{P}$ treatments at $57-\mathrm{d}(F=4.59 ; P=0.04)$, was increased by a salinity and $\mathrm{P}$ interaction at 392-d $(F=7.29 ; P=0.01)$, and was not significantly different among treatments at 741-d (Table 2). Surface water delta $\mathrm{NH}_{4}{ }^{+}$ was lower within $\mathrm{P}$ treatments at $57-\mathrm{d}(F=10.13 ; P<0.01)$, was positive and higher with $\mathrm{P}$ at 392-d $(F=6.47 ; P=0.02)$, and was not different among treatments at 741-d (Table 2). Surface water delta SRP was not different among treatments at 57, 392, nor 741-d (Table 2). Delta surface water salinity was increased with salinity at $57(F=16.31 ; P<$ 0.01), $392(F=68.59 ; P<0.01)$, and 741-d $(F=431.39 ; P<0.01$; Table 3). Delta 
surface water $\mathrm{pH}$ was not different among treatments at 57 nor 392-d, but was lower with salinity at $741-\mathrm{d}(F=4.74 ; P=0.04$, Table 2$)$

In the porewater, the average salinity for the fresh and fresh $+\mathrm{P}$ treatment was $0.44 \pm 0.01$ and $0.47 \pm 0.01$, respectively. The average porewater salinity for salt and salt $+\mathrm{P}$ treatment was $9.03 \pm 0.28$ and $8.63 \pm 0.26$, respectively. Porewater delta DOC was lower with salinity $(F=4.71 ; P=0.04)$ and higher with $\mathrm{P}(F=20.37 ; P<0.01)$ at $57-\mathrm{d}$, higher with salinity at $392-\mathrm{d}(F=47.05 ; P<0.01)$, and with salinity $(F=14.11 ; P<0.01)$ and higher with $\mathrm{P}(F=5.23 ; P=0.03)$ at $741-\mathrm{d}$ (Table 3$)$. Porewater delta $\mathrm{NO}_{3}{ }^{-}$, delta $\mathrm{NO}_{2}^{-}$, and DIN were not different among treatments at 57 and 392-d, but $\mathrm{NO}_{2}^{-}(F=5.29$; $P=0.03)$ and DIN $(F=5.41 ; P=0.03)$ were higher with $\mathrm{P}$ at $741-\mathrm{d}$ (Table 3$)$. Porewater delta $\mathrm{NH}_{4}{ }^{+}$was higher with salinity at $57-\mathrm{d}(F=6.65 ; P=0.02)$, lower with salinity at 392-d $(F=10.73 ; P<0.01)$, and higher with $\mathrm{P}(F=6.55 ; P=0.02)$ and lower with salinity $(F=6.17 ; P=0.02)$ at $741-\mathrm{d}$ (Table 3). Porewater delta SRP was lower with salinity at $57-\mathrm{d}(F=8.28 ; P<0.01)$, was not different among treatments at 392 , and higher with salinity at $741-\mathrm{d}(F=4.69 ; P=0.04$, Table 3$)$. Delta porewater salinity was increased with salinity at $57(F=56.72 ; P<0.01), 392(F=72.74 ; P<0.01)$, and $741-\mathrm{d}$ $(F=114.64 ; P<0.01$, Table 3$)$. Delta porewater $\mathrm{pH}$ was higher with $\mathrm{P}$ at $741-\mathrm{d}(F=$ 11.07; $P<0.01$, Table 3).

\section{Soil elemental composition}

Soil C was not different among treatments at 57-d nor 392-d, however, at 741-d C was reduced 1.36 and 1.33 percent with salinity treatments compared to the fresh treatment and at 0-7.5 $\mathrm{cm}$ and 7.5-15 $\mathrm{cm}$ depths, respectively (Table 4). Soil $\mathrm{N}$ was 
increased in $\mathrm{P}$ treatments at $57-\mathrm{d}(F=13.03 ; P<0.01)$ but was not different among treatments at 392 and 741-d (Table 4). Soil P was higher with P at 57-d in surficial soil pouches $(F=26.83 ; P<0.01)$ and at $392-\mathrm{d}$ at $7.5-15 \mathrm{~cm}$ soil depth $(F=5.07 ; P=0.04)$. However, soil P at 0-7.5 depth at 392-d was not different among treatments (Table 4). Soil $\mathrm{P}$ was higher in the salt $+\mathrm{P}$ treatment than the fresh and fresh $+\mathrm{P}$ treatments at 741 d (Table 4).

\section{Soil extracellular enzyme activities}

Short-term exposure (57-d) to salinity suppressed most enzyme activities except for $\beta$-1,4-cellobiosidase (Figure 1). Phosphatase activity in the salinity treatment was $2.9 \times$ lower compared to the fresh treatment (Figure 1a), arylsulfatase activity in the salinity treatment was $2.4 \times$ lower compared to the fresh treatment (Figure $1 \mathrm{~d}$ ), and $\beta-1,4-$ glucosidase activity in the salinity treatment was $2.8 \times$ lower compared to the fresh treatment (Figure 1g). Phosphatase activity in the salt $+\mathrm{P}$ treatment was $1.8 \times$ lower compared to the fresh treatment, however, for both arylsulfatase and $\beta$-1,4-glucosidase the salt $+\mathrm{P}$ treatment activities were not different from the fresh treatment (Figure 1)

After 392-d, phosphatase activity was no longer suppressed with salinity and was not different among treatments within the $0-7.5 \mathrm{~cm}$ or the $7.5-15 \mathrm{~cm}$ soil depth (Figure 1b). However, arylsulfatase activity was reduced in the $0-7.5 \mathrm{~cm}$ depth with salinity and salt $+\mathrm{P}$ and was $3.7 \times$ and $2.5 \times$ lower respectively when compared to the fresh treatment (Figure 1e). B-1,4-glucosidase activity was reduced with salinity in both depths and was $3.7 \times$ and $2.9 \times$ lower within the salinity treatment compared to the fresh treatment within the 0-7.5 and 7.5-15 $\mathrm{cm}$ depth respectively (Figure 1h). $\beta$-1,4-cellobiosidase activity was 
also reduced 5.1× within the salinity treatment compared to the fresh treatment in the 0 $7.5 \mathrm{~cm}$ depth (Figure 1k). When salinity was combined with added P, arylsulfatase activities remained suppressed within the 0-7.5 depth, however, in the salinity and $\mathrm{P}$ combination treatment, both $\beta$-1,4-glucosidase and $\beta$-1,4-cellobiosidase activities were like the control activity level within both the 0-7.5 and 7.5-15 $\mathrm{cm}$ depth (Figure 1).

After 741-d, enzyme activity was low or non-detectable across enzymes and among treatments, though they were not significantly different from the fresh treatment except both $\mathrm{C}$-acquiring enzymes ( $\beta$-1,4-glucosidase and $\beta$-1,4-cellobiosidase) in the 7.515 depth (Figure 1). Salinity lowered the activity of $\beta-1,4$-glucosidase and $\beta-1,4-$ cellobiosidase (Figure 1i,11).

\section{Soil microbial respiration rates and biomass carbon}

Soil microbial respiration rates were enhanced by the main effect of salinity at 57d, however only the F-test was significant $(P=0.04$, Supplemental Table 1$)$, the Tukey post hoc test was not (Figure 2). Soil microbial respiration rates were only affected by salinity within the lower soil depth after 392-d of exposure; however only the F test was significant $(P=0.05$, Supplemental Table 1), the Tukey follow-up test was not (Figure 2). After 392-d, there were no differences in microbial biomass $\mathrm{C}$ at $0-7.5 \mathrm{~cm}$ depth (Figure 3a). However, at 7.5-15 $\mathrm{cm}$ depth, microbial biomass was suppressed in the salinity and salt $+\mathrm{P}$ treatments compared to the fresh $+\mathrm{P}$ treatment (Figure 3a). On the 741-d collection, there were no differences among treatments in microbial biomass $\mathrm{C}$ in both the $0-7.5 \mathrm{~cm}$ and $7.5-15 \mathrm{~cm}$ depths (Figure $3 \mathrm{~b}$ ). 


\section{Root litter breakdown}

Root litter $k$ within the $0-7.5 \mathrm{~cm}$ soil depth was higher in the fresh $+\mathrm{P}$ and salt $+\mathrm{P}$ treatments and was $1.5 \times$ greater for both when compared to the fresh treatment (Figure 4a). However, within the $7.5-15 \mathrm{~cm}$ depth root litter $k$ was only significantly higher in the fresh $+\mathrm{P}$ treatment which was $1.7 \times$ greater compared to the fresh treatment. Neither phosphatase activity or $\beta$-1,4-cellobiosidase measured on the roots were different among treatments at any depth (Figure 4b). Arylsulfatase within the 0-7.5 $\mathrm{cm}$ depth was significantly lower in the salt $+\mathrm{P}$ treatment compared to the control and was $2.9 \times$ lower compared to the fresh treatment (Figure 4c). Similarly, $\beta$-1,4-glucosidase activity for the salinity treatment was significantly lower, within the $0-7.5 \mathrm{~cm}$ depth, and was $1.7 \times$ lower compared to the fresh treatment (Figure 4d).

\section{DISCUSSION}

We assessed the response of microbially-mediated soil organic matter processing, soil elemental composition, and water chemistry to short-, intermediate-, and long-term changes in salinity and nutrient exposure. Our results inform our understanding of how ecosystem-level processes, like the formation and collapse of peat soils in subtropical wetlands, are affected by changing biogeochemical conditions. Exposure to salinity elicited strong functional responses in soil microbes including decreased enzyme activities, and exposure to $\mathrm{P}$ increased root litter $k$ but had little effect on soil microbial biomass or respiration rates. We measured increased surface water DOC and TOC, and decreased soil C, attributed to increased salinity, and enhanced breakdown of root liter, attributed to increased $\mathrm{P}$. 
Saltwater intrusion increases the concentrations of dissolved ions causing desorption of organic compounds from exchange sites and making them available within the soil porewater (Liu and Lee 2007). Adsorption and desorption dynamics were altered with exposure to salinity resulting in early changes in surface and porewater constituents that varied over time. We measured increased surface water TOC and porewater DOC from soils exposed to increased salinity at intermediate- and long-term exposure. Shortterm exposure did not result in increases in TOC and DOC, indicating small ( 1.3 ppt) increases in salinity do not elicit releases of TOC and DOC. Similarly, $\mathrm{NH}_{4}{ }^{+}$and SRP can be desorbed following the addition of other cations in saline waters (Rosenfeld 1979; Ardón et al. 2013). In our study, we saw evidence of potential short-term desorption of porewater $\mathrm{NH}_{4}{ }^{+}$and SRP within our salinity treatment. However, intermediate- and longterm exposure to salinity led to reductions in $\mathrm{NH}_{4}{ }^{+}$indicating plants took up available ammonium. However, total $\mathrm{N}$ content in the aboveground biomass of the sawgrass in the salinity treatment was only slightly higher than the freshwater controls and was not significantly different (B. Wilson, personal communication). Short-term exposure to elevated P increased surface water TP availability. Elevated salinity also increased TP availability but only after intermediate-term exposure. Previously adsorbed nutrients released following SWI would then be available for uptake by plants and periphyton or be exported from the marsh to the estuary.

Exposure to elevated $\mathrm{P}$ increased soil $\mathrm{P}$ when algal and plant competition for $\mathrm{P}$ was reduced. Increased soil P was not evident at the 392-d collection in the shallow (0$7.5 \mathrm{~cm}$ ) soil depth, but was significantly higher in deeper soil at 392-d and both depths after longer-term exposure, particularly in the salinity $+\mathrm{P}$ treatment. The delayed 
expression of elevated soil P in soil removed from the monoliths compared to the soil pouches suspended in the water column is likely caused by greater surface area exposed to $\mathrm{P}$ enriched water. Suspended soil subsamples maximized exposure and prevented plant competition for porewater P. Soil subsamples taken directly from sawgrass cores were exposed to lesser amounts of $\mathrm{P}$ because this nutrient is rapidly assimilated by algal mats on the soil surface and by sawgrass roots. Algal mats can act as a short-term P sink until saturated; once these organisms are no longer P-limited, excess $\mathrm{P}$ can accumulate in the soil as we saw after long-term exposure (Richardson and Craft 1993; Reddy et al. 1999; McCormick et al. 2006). Coastal wetlands with underlying calcium carbonate bedrock will likely see increased P following SWI, and understanding the phases of biological responses to newly available $\mathrm{P}$ will inform how nutrient limitation may change (Flower et al. 2017).

Early surficial enzyme activities provide evidence of the short-term sensitivity of freshwater soil microbial communities to low-concentration salinity exposure. Salinity consistently either suppressed enzyme activities or did not affect it. All enzymes, except $\beta$-1,4-cellobiosidase, were suppressed after short-term exposure to elevated salinity, a finding that is supported by other studies that manipulated salinity effects on soils (Pathak and Rao 1998, Saviozzi et al. 2011). Short-term reduction of enzyme activities is likely a result of microbial communities diverting resources from the production of extracellular enzymes to the production of osmolytes to maintain cell turgor (Kempf and Bremer 1998). Interestingly, for arylsulfatase and $\beta-1,4$-glucosidase, salinity suppression was absent with added $\mathrm{P}$, indicating that nutrient subsidies can mitigate short-term effects of stressors on nutrient acquiring enzymes. 
Exposure to elevated salinity continued to suppress enzyme activities in the soil cores collected from the monoliths. After 392-d both C acquiring enzymes ( $\beta-1,4-$ glucosidase and $\beta$-1,4-cellobiosidase) were decreased within the salinity treatment. However, there appears to be a continuation of the mitigating effect with added $\mathrm{P}$ as salt $+\mathrm{P}$ did not have suppressed $\mathrm{C}$ acquiring enzymes. Previous studies that have documented how nutrient exposure can alleviate stress effects of contaminants indicating simultaneous exposure to salinity and P may elicit different microbial responses than salinity alone (Aristi et al. 2016). Enzyme activities in the lower soil depth were mostly unaffected by salinity and $\mathrm{P}$ treatments, except for $\beta$-1,4-glucosidase activity which followed the same pattern as the surficial soil. After intermediate-term exposure to salinity and $\mathrm{P}$, phosphatase activities were no longer different among treatments and were likely less susceptible to sustained exposure to environmental stressors and indicates the microbial demand for $\mathrm{P}$ was similar across treatments. Long-term effects of exposure to salinity and $\mathrm{P}$ on enzyme activities were similar to intermediate-term responses. On the 741-d collection, both C-acquiring enzymes ( $\beta$-1,4-glucosidase and $\beta$-1,4-cellobiosidase) were suppressed. Salinity suppression of C-acquiring enzymes within deeper soil may have occurred as result of the movement of denser saltwater lower into the soil profile increasing osmotic stress to microbes at lower soil depths (Empadinhas and da Costa 2008). Salinity suppression of C enzymes appears to be sustained long-term, while nutrient-acquiring enzymes are only affected after short to intermediate-duration exposure.

Saltwater and nutrient exposure can enhance soil respiration rates leading to net losses of ecosystem C stores (Howarth and Fischer 1976; Robinson and Gessner 2000; 
Chambers et al. 2011). We detected short-term enhancement of soil respiration. However, soil microbial respiration rates and microbial biomass were unaffected or were suppressed after intermediate- and long-term exposure. It is possible that we were unable to capture changes in soil respiration and that time attenuated the response of soil microbial respiration to long-term exposure to increases in salinity and $\mathrm{P}$ as communities adapt to environmental conditions. However, within our study, soil $\mathrm{CO}_{2}$ efflux captured treatment effects on soil and root respiration and showed salinity consistently reduced soil $\mathrm{CO}_{2}$ efflux (B. Wilson, personal communication). Although negative relationships between increased salinity and microbial biomass have been observed (Malik and Azam 1980; Egamberdieva et al. 2010), other studies found that increased salinity resulted in higher microbial biomass (Wong et al. 2008). Here, we only observed a change in microbial biomass after intermediate-term exposure in the deeper, less active, soil. The reduction in biomass after intermediate-term exposure is likely a result of increased exposure to salinity at lower depths because of higher density saltwater settling towards the bottom of treatment monoliths and higher biomass in freshwater soils with added P. Enzyme activity suppression has previously been attributed to smaller, less active, microbial communities (Caravaca et al. 2005; Huang and Morris 2005). Here, we did not see sustained changes in microbial biomass $\mathrm{C}$ or respiration, so there may be a disconnect between microbial community function (enzyme activity), size (biomass), and activity (respiration).

Long-term exposure to salinity resulted in decreases in soil $\mathrm{C}$ at 741-d for both soil depths. The reduction of $\mathrm{C}$ after long-term exposure to salinity is one potential pathway towards peat collapse and may represent the source of TOC and DOC within the 
surface and porewater. However, increases in intermediate- and long-term surface and porewater TOC and DOC losses do not appear to be connected with the changes in microbial community function (Table 5). We would have expected the released DOC to be used by the water column and soil microbial community for metabolism and result in increased respiration, which may explain short-term responses (Table 5, Liu and Lee 2007; Weston 2011). However, the loss of $\mathrm{C}$ from the soil and increased concentrations of TOC and DOC in the water after intermediate- and long-term exposure to salinity do not appear to be biologically controlled by the soil microbial community (Table 5). Enzymes associated with $\mathrm{C}$ acquisition, microbial biomass $\mathrm{C}$, and soil respiration were never enhanced and appear to be disconnected from the loss of soil C and from TOC and DOC release (Table 5). If $\mathrm{C}$ losses were dominated by microbial processing, we would expect increased soil respiration and $\mathrm{CO}_{2}$ efflux (Weston et al. 2006).

Accelerating sea level rise is fundamentally altering biogeochemical cycles in coastal wetlands with uncertain effects on net $\mathrm{C}$ gains or losses. In our study, $\mathrm{P}$ addition enhanced C losses by increasing root litter $k$. In nutrient-poor soils, plants often have high nutrient resorption resulting in poor litter quality and slow decomposition rates (Aerts and Chapin 2000; Rejmankova 2005). Previous studies have shown that breakdown of organic matter increases with nutrient addition (Howarth and Fischer 1976; Robinson and Gessner 2000) and salinity exposure (Weston et al. 2011). Increased root litter $k$ with P is a potential mechanism of peat collapse with lower levels of salinity because in the salinity $+\mathrm{P}$ treatment $k$ was also increased, but only within the $0-7.5 \mathrm{~cm}$ depth (Figure 4a). In the Everglades SWI and P inputs are coupled (Price et al. 2006), and direct effects of $\mathrm{P}$ on breakdown will affect organic $\mathrm{C}$ accumulation in the soil. Even low levels of 
saltwater intrusion through the limestone bedrock of the Everglades has the potential to release adsorbed P into the water column (Flower et al. 2017). Despite changes in root litter $k$ being attributed to $\mathrm{P}$ exposure, enzyme activities measured on root were either unaffected by treatments or were reduced with salinity exposure. Among the treatments, the potential activity phosphatase, arylsulfatase, $\beta$-glucosidase, and cellulase enzymes resulted in similar breakdown efficiencies.

\section{CONCLUSION}

Land-use and climate changes are altering the supply of water and nutrients to coastal wetland ecosystems (Ardón et al. 2013, Deegan et al. 2012, Weston 2014). Previous conditions promoting wetland $\mathrm{C}$ storage are rapidly altered by multiple interacting stressors. We measured significant effects of salinity on surface and porewater $\mathrm{C}$, soil $\mathrm{C}$, and the soil microbial community. We were able to document how the dominant pathway behind soil $\mathrm{C}$ loss in the Everglades was through translocation of $\mathrm{C}$ from the soils to the water column (DOC and TOC) with salinity exposure and increased root litter $k$ with $\mathrm{P}$ exposure. Although microbial community function can be used as an indicator of ecosystem health, as freshwater communities are particularly sensitive to salinity exposure, the link between changing microbial function and $\mathrm{C}$ loss needs further work. To understand how SWI will affect the fate of wetland microbial biogeochemical pathways, the shape of these responses, including those of the plant community, must be determined. Phosphorous exposure has the potential to offset some of the effects of salinity and understanding how different ratios of subsidy to stress inputs affect ecosystem responses will help inform future resilience of coastal wetlands. 


\section{REFERENCES}

1. Ardón, M., Morse, J.L., Colman, B.P., Bernhardt, E.S., 2013. Drought-induced saltwater incursion leads to increased wetland nitrogen export. Global Change Biology 19, 2976-2985.

2. Aristi, I., Casellas, M., Elosegi, A., Insa, S., Petrovic, M., Sabater, S., Acuña, V., 2016. Nutrients versus emerging contaminants-or a dynamic match between subsidy and stress effects on stream biofilms. Environmental Pollution 212, 208215.

3. Benfield, E.F., 2006. Decomposition of leaf material, in: Hauer, H., Lamberti, G. (Eds.), Methods in Stream Ecology, $2^{\text {nd }}$ Edition. Academic Press, pp. 711-720.

4. Berner, E.K., \& Berner, R.A., 2012. Global environment: water, air, and geochemical cycles. Princeton University Press.

5. Boyer J.N., Fourqurean, J.W., Jone,s R.D., 1999. Seasonal and long-term trends in the water quality of Florida Bay (1989-1997). Estuaries 22, 417-430.

6. Caravaca, F., del Mar Alguacil, M., Torres, P., Roldán, A., 2005. Microbial activities and arbuscular mycorrhizal fungi colonization in the rhizosphere of the salt marsh plant Inula crithmoides L. along a spatial salinity gradient. Wetlands $25,350-355$.

7. Chambers, L.G., Reddy, K.R., Osborne, T.Z., 2011. Short-term response of carbon cycling to salinity pulses in a freshwater wetland. Soil Science Society of America Journal 75, 2000-2007.

8. Chambers, L.G., Davis, S.E., Troxler, T., Boyer, J.N., Downey-Wall, A., Scinto, L.J. 2014. Biogeochemical effects of simulated sea level rise on carbon loss in an Everglades mangrove peat soil. Hydrobiologia 726, 195-211.

9. Childers D.L., Boyer, J.N., Davis, S.E., Madden, C.J., Rudnick, D.T., Sklar, F.H., 2006. Relating precipitation and water management to nutrient concentrations in the oligotrophic" upside-down" estuaries of the Florida Everglades. Limnology and Oceanography 51, 602-616.

10. Deegan, L. A., Johnson, D.S., Warren, R.S., Peterson, B.J., Fleeger, J.W., Fagherazzi, S., Wollheim, W.M., 2012. Coastal eutrophication as a driver of salt marsh loss. Nature 490, 388-392.

11. DeLaune, R.D., Nyman, J.A., Patrick Jr, W.H., 1994. Peat collapse, ponding and wetland loss in a rapidly submerging coastal marsh. Journal of Coastal Research, 1021-1030.

12. Dick, R.P., 1994. Soil enzyme activities as indicators of soil quality, in: Doran, J.W., Coleman, D.C., Bezdicek, D.F., Stewart, B.A. (Eds.), Defining Soil Quality for a Sustainable Environment. Soil Science Society of America, Madison, pp. 107-124. 
13. Egamberdieva, D., Renella, G., Wirth, S., Islam, R., 2010. Secondary salinity effects on soil microbial biomass. Biology and Fertility of Soils 46, 445-449.

14. Empadinhas, N., da Costa, M. S., 2008. Osmoadaptation mechanisms in prokaryotes: distribution of compatible solutes. International Microbiology 11, $151-61$

15. Faulkner, S.P., Patrick Jr., W.H., Gambrell, R.P., 1989. Field techniques for measuring wetland soil parameters. Soil Science Society of America Journal 53, $883-890$

16. Flower, H., Rains, M., Lewis, D., Zhang, J.Z., Price, R., 2017 Saltwater intrusion as a potential driver of phosphorus release from limestone bedrock in coastal aquifer. Estuarine, Coastal, and Shelf Science 184,166-176.

17. Fourqurean, J.W., Jones, R.D., Zieman, J.C., 1993 Process influencing water column nutrient characteristics and phosphorus limitation of phytoplankton biomass in Florida Bay, FL, USA: inferences from spatial distributions. Estuarine, Coastal and Shelf Science 36, 295-314.

18. Frankenberger, W.T., Bingham, F.T., 1982. Influence of salinity on soil enzyme activities. Soil Science Society of America Journal 46, 1173-1177.

19. Green, A.J., Alcorlo, P., Peeters, E.T., Morris, E.P., Espinar, J.L., Bravo-Utrera, M.A., ... \& Mooij, W.M., 2017 Creating a safe operating space for wetlands in a changing climate. Frontiers in Ecology and the Environment 15, 99-107.

20. Helton, A.M., Ardón, M., Bernhardt, E.S., 2015 Thermodynamic constraints on the utility of ecological stoichiometry for explaining global biogeochemical patterns. Ecology Letters 18, 1049-1056.

21. Howarth, R.W., Fisher, S.G., 1976 Carbon, nitrogen, and phosphorus dynamics during leaf decay in nutrient-enriched stream microecosystems. Freshwater Biology 6, 221-228.

22. Huang, X., Morris, J.T., 2005. Distribution of phosphatase activity in marsh sediments along an estuarine salinity gradient. Marine Ecology Progress Series 292, 75-83.

23. Jackson, C.R., Vallaire, S.C., 2009. Effects of salinity and nutrients on microbial assemblages in Louisiana wetland sediments. Wetlands 29, 277-287.

24. Kempf, B., Bremer, E., 1998. Uptake and synthesis of compatible solutes as microbial stress responses to high-osmolality environments. Archives of Microbiology 170, 319-330.

25. Liu, Z., Lee, C., 2007. The role of organic matter in the sorption capacity of marine sediments. Marine Chemistry 105, 240-257. 
26. Malik, K.A., Azam, F., 1980. Effect of salinity on ${ }^{14}$ C-labelled microbial biomass and its contribution to soil organic matter. Pakistan Journal of Botany 12, 117127.

27. McCormick, P.V., Shuford, R.B., Chimney, M.J. 2006. Periphyton as a potential phosphorus sink in the Everglades Nutrient Removal Project. Ecological Engineering 27, 279-289.

28. Morrison, E., Newman, S., Bae, H.S., He, Z., Zhou, J., Reddy, K.R., Ogram, A., 2016. Microbial genetic and enzymatic responses to an anthropogenic phosphorus gradient within a subtropical peatland. Geoderma 268, 119-127.

29. Neubauer, S.C., 2013. Ecosystem responses of a tidal freshwater marsh experiencing saltwater intrusion and altered hydrology. Estuaries and Coasts 36, 491-507.

30. Noe, G.B., Childers, D.L., Jones, R.D., 2001. Phosphorus biogeochemistry and the impact of phosphorus enrichment: Why is the Everglades so unique?

Ecosystems 4, 603-624.

31. Penton, R.C., Newman, S., 2007. Enzyme activity responses to nutrient loading in subtropical wetlands. Biogeochemistry 84, 83-98.

32. Price, R.M., P.K. Swart, Fourqurean J.W., 2006. Coastal groundwater discharge an additional source of phosphorus for the oligotrophic wetlands of the Everglades. Hydrobiologia 569, 23-36.

33. Price, R.M., Savabi, M.R., Jolicoeur, J.L., Roy, S., 2010. Adsorption and desorption of phosphate on limestone in experiments simulating seawater intrusion. Applied Geochemistry 25, 1085-1091.

34. Reddy, K.R., Kadlec, R.H., Flaig, E., Gale, P.M., 1999. Phosphorus retention in streams and wetlands: a review. Critical Reviews in Environmental Science and Technology 29, 83-146.

35. Rejmánková, E., 2005. Nutrient resorption in wetland macrophytes: comparison across several regions of different nutrient status. New Phytologist 167, 471-482.

36. Rejmánková, E., Sirova, D., 2007. Wetland macrophyte decomposition under different nutrient conditions: relationships between decomposition rate, enzyme activities and microbial biomass. Soil Biology and Biochemistry 39, 526-538.

37. Richardson, C.J., Craft, C.B., 1993. Effective phosphorus retention in wetlands: fact or fiction. Constructed Wetlands for Water Quality Improvement 271-282.

38. Rietz, D.N., Haynes, R.J., 2003. Effects of irrigation-induced salinity and sodicity on soil microbial activity. Soil Biology and Biochemistry 35, 845-854.

39. Robinson, C.T., Gessner, M.O., 2000. Nutrient addition accelerates leaf breakdown in alpine springbrook. Oecologia 122, 258-263. 
40. Rosenfeld, J.K., 1979. Ammonium adsorption in nearshore anoxic sediments. Limnology and Oceanography 24, 356-364.

41. Saiya-Cork, K.R., Sinsabaugh, R.L., Zak, D.R., 2002. The effects of long term nitrogen deposition on extracellular enzyme activity in an Acer saccharum forest soil. Soil Biology and Biochemistry 34, 1309-1315.

42. Sinsabaugh, R.L., Carreiro, M.M., Repert, D.A., 2002. Allocation of extracellular enzymatic activity in relation to litter composition, $\mathrm{N}$ deposition, and mass loss. Biogeochemistry 60, 1-24.

43. Vance, E.D., Brookes, P.C., Jenkinson, D.S., 1987. An extraction method for measuring soil microbial biomass carbon. Soil Biology and Biochemistry 19, 703707.

44. Weston, N.B., Dixon, R.E., Joye, S.B. 2006. Ramifications of increased salinity in tidal freshwater sediments: Geochemistry and microbial pathways of organic matter mineralization. Journal of Geophysical Research: Biogeosciences 111(G1).

45. Weston, N.B., Vile, M.A., Neubauer, S.C., Velinsky, D.J., 2011. Accelerated microbial organic matter mineralization following salt-water intrusion into tidal freshwater marsh soils. Biogeochemistry 102, 135-151.

46. Wright, A.L., Reddy, K.R., 2001. Phosphorus loading effects on extracellular enzyme activity in Everglades wetland soils. Soil Science Society of America Journal 65, 588-595.

47. White, E., Kaplan, D., 2017. Restore or retreat? Saltwater intrusion and water management in coastal wetlands. Ecosystem Health and Sustainability 3(1).

48. Wong, V.N., Dalal, R.C., Greene, R.S. 2008. Salinity and sodicity effects on respiration and microbial biomass of soil. Biology and Fertility of Soils 44, $943-$ 953.

49.

\section{ACKNOWLEDGMENTS}

We thank L. Bauman, G. Cabral, K. Morales, and D. Segrera for laboratory assistance.

Funding for this research was provided by the National Science Foundation award (DBI-

1237517) to the Florida Coastal Everglades Long Term Ecological Research (FCE

LTER) Program. S. Servais was supported by research assistantships from Florida Sea

Grant (R/C-S-56) and FCE LTER, teaching assistantship for Florida International

University, and Florida International University’s Dissertation Year Fellowship. We 
thank the Everglades Section of the South Florida Water Management District and Everglades National Park for providing facilities support during this research. 
Table 1. Enzymes analyzed, corresponding Enzyme commission number (EC), the substrate used in the assay, enzyme function, and the predicted response to additions of salinity and phosphorus $(\mathrm{P})$.

\begin{tabular}{|c|c|c|c|c|c|c|}
\hline Enzyme & $\mathrm{EC}$ & Substrate & Function & $\begin{array}{l}\text { predicted } \\
\text { salt effect }\end{array}$ & $\begin{array}{c}\text { predicted } \mathrm{P} \\
\text { effect }\end{array}$ & $\begin{array}{l}\text { predicted } \\
\text { salt }+\mathrm{P}\end{array}$ \\
\hline $\begin{array}{l}\text { Acid and Alkaline } \\
\text { Phosphatase }\end{array}$ & 3.1 .3 .2 & 4-MUF- phosphate & $\begin{array}{l}\text { Hydrolyzes phospholipids and } \\
\text { phosphosaccarides }\end{array}$ & $\downarrow$ & $\downarrow$ & $\downarrow$ \\
\hline$\beta-1,4-$ Cellobiosidase & 3.2 .1 .91 & 4-MUF- $\beta$-D cellobioside & $\begin{array}{l}\text { Hydrolyzes linkages in } \\
\text { cellulose and cellotetraose }\end{array}$ & $\downarrow$ & $\uparrow$ & $\leftrightarrow$ \\
\hline$\beta-1,4-$ Glucosidase & 3.2 .1 .21 & 4-MUF $\beta$-D-glucopyranoside & Hydrolyzes $\beta$-D-glucosyl & $\downarrow$ & $\uparrow$ & $\leftrightarrow$ \\
\hline Arylsulfatase & 3.1.6.1 & 4-MUF-sulfate & Hydrolyzes sulfoester bonds & $\downarrow$ & $\leftrightarrow$ & $\downarrow$ \\
\hline
\end{tabular}


Table 2. Average ( \pm 1 standard error) delta surface water constituents between initial and the $57-\mathrm{d}$ collection, 57-d, and 392-d collection, and 392-d and 741-d collection. Units for total organic carbon (TOC), total nitrogen (TN), total phosphorus (TP), dissolved organic $\mathrm{C}(\mathrm{DOC})$, nitrate $\left(\mathrm{NO}_{3}{ }^{-}\right)$, nitrite $\left(\mathrm{NO}_{2}{ }^{-}\right)$, dissolved inorganic nitrogen (DIN), ammonium $\left(\mathrm{NH}_{4}{ }^{+}\right)$, and soluble reactive phosphorus (SRP) are $\mu \mathrm{mol} \mathrm{L}^{-1}$. Units for salinity are parts per thousand. Positive delta values represent net increases in the constituent while negative values represent net decreases in the constituent. Nitrate $\left(\mathrm{NO}_{3}{ }^{-}\right)$was below the detection limit (BDL) at 741-d, and therefore no delta is reported. Data were analyzed using a two-way ANOVA. Significant effects and interaction terms are reported in the last column. "NS" indicates not significant $(P>0.05)$. * indicates $\mathrm{P}>0.05$ and $* *$ indicates $P>0.005$.

\begin{tabular}{|c|c|c|c|c|c|}
\hline \multirow[b]{2}{*}{ parameter } & \multicolumn{4}{|c|}{ treatment } & \multirow[b]{2}{*}{ significant effect } \\
\hline & fresh & fresh $+\mathrm{P}$ & salt & salt $+\mathrm{P}$ & \\
\hline \multicolumn{6}{|l|}{57 days } \\
\hline TOC & $-229(274)$ & $146(45)$ & $77(70)$ & $-319(42)$ & salt $\times \mathrm{P}^{*}$ \\
\hline $\mathrm{TN}$ & $5.95(3.02)$ & $4.48(2.60)$ & $14.13(5.34)$ & $-10.52(3.62)$ & $\mathrm{P}^{* *}$, salt $\times \mathrm{P}^{*}$ \\
\hline TP & $-0.28(0.12)$ & $-0.03(0.05)$ & $-0.20(0.04)$ & $0.11(0.10)$ & $\mathrm{P}^{* *}$ \\
\hline DOC & $-164(99)$ & $-1.8(71)$ & $-237(64)$ & $-250(73)$ & NS \\
\hline $\mathrm{NO}_{3}^{-}$ & $-1.32(1.02)$ & $-1.72(0.80)$ & $-0.08(0.36)$ & $-3.13(0.90)$ & $\mathrm{P}^{*}$ \\
\hline $\mathrm{NO}_{2}^{-}$ & $0.01(0.03)$ & $0.00(0.01)$ & $0.04(0.01)$ & $-0.05(0.02)$ & NS \\
\hline DIN & $-1.33(1.04)$ & $-1.71(0.81)$ & $-0.03(0.37)$ & $-3.18(0.91)$ & $\mathrm{P}^{*}$ \\
\hline $\mathrm{NH}_{4}^{+}$ & $1.04(1.08)$ & $-1.68(0.92)$ & $0.77(0.41)$ & $-1.95(0.87)$ & $\mathrm{P}^{* *}$ \\
\hline SRP & $0.02(0.02)$ & $0.06(0.05)$ & $0.00(0.01)$ & $0.01(0.02)$ & NS \\
\hline salinity & $0.36(0.30)$ & $-0.01(0.10)$ & $1.33(0.44)$ & $1.86(0.44)$ & salt** \\
\hline $\mathrm{pH}$ & $0.00(0.14)$ & $0.32(0.17)$ & $0.00(0.20)$ & $0.27(0.15)$ & NS \\
\hline \multicolumn{6}{|l|}{392 days } \\
\hline TOC & $-264(60)$ & $-393(38)$ & $393(115)$ & 851.57 (117) & salt ${ }^{* *}$, salt $\times \mathrm{P}^{* *}$ \\
\hline TN & $-5.02(3.48)$ & $-7.32(1.89)$ & $20.18(7.90)$ & $52.62(6.30)$ & $\begin{array}{l}\text { salt**, } \mathrm{P}^{*} \text {, salt } \times \\
\mathrm{P}^{* *}\end{array}$ \\
\hline ТP & $-0.18(0.06)$ & $-0.11(0.14)$ & $-0.03(7.90)$ & $0.24(0.15)$ & salt* \\
\hline DOC & $-95(84)$ & $-284(140)$ & $504(120)$ & $701(51)$ & salt** \\
\hline $\mathrm{NO}_{3}^{-}$ & $-0.27(0.05)$ & $-0.32(0.08)$ & $-0.53(0.12)$ & $-0.17(0.02)$ & salt $\times \mathrm{P}^{*}$ \\
\hline $\mathrm{NO}_{2}^{-}$ & $-0.02(0.02)$ & $-0.05(0.02)$ & $-0.03(0.01)$ & $0.02(0.00)$ & NS \\
\hline DIN & $-0.32(0.07)$ & $-0.390 .10)$ & $-0.56(0.12)$ & $-0.15(0.02)$ & salt $\times \mathrm{P}^{*}$ \\
\hline $\mathrm{NH}_{4}^{+}$ & $-0.95(0.97)$ & $0.93(0.50)$ & $-0.26(0.58)$ & $1.08(0.29)$ & $\mathrm{P}^{*}$ \\
\hline SRP & $0.00(0.02)$ & $0.04(0.10)$ & $0.01(0.01)$ & $-0.01(0.02)$ & NS \\
\hline salinity & $-0.34(0.13)$ & $-0.07(0.03)$ & $2.31(0.40)$ & $2.29(0.43)$ & salt** \\
\hline $\mathrm{pH}$ & $-0.41(0.24)$ & $-0.23(0.06)$ & $-0.45(0.12)$ & $1.39(1.28)$ & NS \\
\hline \multicolumn{6}{|l|}{741 days } \\
\hline TOC & $1196(114)$ & 931 (179) & $1846(156)$ & $1591(288)$ & salt** \\
\hline $\mathrm{TN}$ & 41.55 (6.99) & $38.25(10.57)$ & 99.49 (7.13) & $76.50(18.61)$ & salt** \\
\hline TP & $0.24(0.11)$ & $0.43(0.22)$ & $0.60(0.23)$ & $1.26(0.61)$ & NS \\
\hline DOC & $910(167)$ & 881 (108) & 1673 (297) & 874 (403) & NS \\
\hline $\mathrm{NO}_{3}^{-}$ & BDL & BDL & BDL & BDL & NS \\
\hline $\mathrm{NO}_{2}^{-}$ & $0.04(0.01)$ & $0.05(0.02)$ & $0.11(0.05)$ & $0.24(0.07)$ & salt* \\
\hline DIN & $0.08(0.03)$ & $0.89(0.44)$ & $0.04(0.04)$ & $0.15(0.07)$ & NS \\
\hline $\mathrm{NH}_{4}^{+}$ & $0.14(0.22)$ & $0.54(0.39)$ & $0.43(0.34)$ & $0.08(0.43)$ & NS \\
\hline SRP & $-0.01(0.02)$ & $0.05(0.09)$ & $0.00(0.01)$ & $0.20(0.14)$ & NS \\
\hline salinity & $0.28(0.02)$ & $0.29(0.06)$ & $4.63(0.26)$ & $4.51(0.31)$ & salt** \\
\hline $\mathrm{pH}$ & $-0.17(0.19)$ & $-0.16(0.08)$ & $-0.43(0.06)$ & $-0.47(0.14)$ & salt* \\
\hline
\end{tabular}


Table 3. Average ( \pm 1 standard error) delta porewater constituents between initial and the $57-\mathrm{d}$ collection, 57-d, and 392-d collection, and 392-d and 741-d collection. Units for total organic carbon (TOC), total nitrogen (TN), total phosphorus (TP), dissolved organic $\mathrm{C}(\mathrm{DOC})$, nitrate $\left(\mathrm{NO}_{3}{ }^{-}\right)$, nitrite $\left(\mathrm{NO}_{2}^{-}\right)$, dissolved inorganic nitrogen (DIN), ammonium $\left(\mathrm{NH}_{4}{ }^{+}\right)$, and soluble reactive phosphorus (SRP) are $\mu \mathrm{mol} \mathrm{L}^{-1}$. Positive delta values represent net increases in the constituent while negative values represent net decreases in the constituent. Nitrate $\left(\mathrm{NO}_{3}{ }^{-}\right)$was below the detection limit (BDL) at 741-d, and therefore no delta is reported. Porewater $\mathrm{pH}$ was not recorded at 57-d; therefore, delta porewater $\mathrm{pH}$ is not reported for 57 and 392-d. Data were analyzed using a two-way ANOVA.

Significant effects and interaction terms are reported in the last column. "NS" indicates not significant $(P>0.05)$. * indicates $P>0.05$ and $* *$ indicates $P>0.005$.

\begin{tabular}{|c|c|c|c|c|c|}
\hline \multirow[b]{2}{*}{ parameter } & \multicolumn{4}{|c|}{ treatment } & \multirow[b]{2}{*}{$\begin{array}{l}\text { significant } \\
\text { effect }\end{array}$} \\
\hline & fresh & fresh $+P$ & salt & salt $+\mathrm{P}$ & \\
\hline \multicolumn{6}{|l|}{57 days } \\
\hline DOC & & 393.93 & & & salt*, $\mathrm{P}^{* *}$ \\
\hline & $-349(126)$ & (72.69) & $-533(202)$ & $-24.1(122)$ & \\
\hline $\mathrm{NO}_{3}^{-}$ & $0.21(0.08)$ & $0.04(0.10)$ & $0.19(0.07)$ & $-0.05(0.28)$ & NS \\
\hline $\mathrm{NO}_{2}^{-}$ & $-0.01(0.01)$ & $-0.03(0.01)$ & $-0.02(0.02)$ & $-0.09(0.08)$ & NS \\
\hline DIN & $0.29(0.05)$ & $0.05(0.10)$ & $0.29(0.05)$ & $-0.14(0.33)$ & NS \\
\hline $\mathrm{NH}_{4}{ }^{+}$ & $0.56(0.50)$ & $1.20(1.02)$ & $15.99(7.26)$ & $19.13(10.59)$ & salt* \\
\hline SRP & $0.01(0.02)$ & $0.02(0.00)$ & $-0.04(0.02)$ & $-0.01(0.01)$ & salt* \\
\hline salinity & $-0.61(0.27)$ & $-0.31(0.06)$ & $1.25(0.36)$ & $1.38(0.15)$ & salt* \\
\hline \multicolumn{6}{|l|}{392 days } \\
\hline DOC & $-401(133)$ & $-520(283)$ & $931(152)$ & 777 (162) & salt** \\
\hline $\mathrm{NO}_{3}^{-}$ & $-0.18(0.09)$ & $0.02(0.20)$ & $-0.11(0.06)$ & $-0.29(0.11)$ & NS \\
\hline $\mathrm{NO}_{2}^{-}$ & $0.00(0.01)$ & $0.07(0.06)$ & $0.05(0.02)$ & $0.06(0.02)$ & NS \\
\hline DIN & $-0.25(0.06)$ & $0.05(0.26)$ & $-0.16(0.03)$ & $-0.22(0.11)$ & NS \\
\hline $\mathrm{NH}_{4}{ }^{+}$ & $-2.01(1.54)$ & $-0.73(2.85)$ & $-31.06(10.81)$ & $-24.99(11.73)$ & salt** \\
\hline SRP & $-0.01(0.01)$ & $0.28(0.19)$ & $0.07(0.02)$ & $0.05(0.02)$ & NS \\
\hline salinity & $0.12(0.04)$ & $0.10(0.04)$ & $4.08(0.77)$ & $3.79(0.46)$ & salt** \\
\hline \multicolumn{6}{|l|}{741 days } \\
\hline DOC & $208(84.8)$ & 464 (189) & 319 (130) & $558(228)$ & salt**, $\mathrm{P}^{*}$ \\
\hline $\mathrm{NO}_{3}^{-}$ & BDL & BDL & BDL & BDL & \\
\hline $\mathrm{NO}_{2}^{-}$ & $0.05(0.02)$ & $0.17(0.07)$ & $0.06(0.02)$ & $0.06(0.02)$ & $\mathrm{P}^{*}$ \\
\hline DIN & $0.31(0.12)$ & $0.61(0.25)$ & $0.27(0.11)$ & $0.16(0.06)$ & $\mathrm{P}^{*}$ \\
\hline $\mathrm{NH}_{4}^{+}$ & $5.34(2.18)$ & $9.03(3.68)$ & $3.74(1.53)$ & $2.95(1.21)$ & salt*, $\mathrm{P}^{*}$ \\
\hline SRP & $0.38(0.16)$ & $0.48(0.19)$ & $0.07(0.03)$ & $0.11(0.05)$ & $\mathrm{P}^{*}$ \\
\hline salinity & $0.07(0.03)$ & $0.18(0.07)$ & $1.14(0.47)$ & $0.40(0.16)$ & salt* \\
\hline $\mathrm{pH}$ & $0.28(0.12)$ & $0.33(0.13)$ & $0.11(0.04)$ & $0.24(0.10)$ & $\mathrm{P}^{*}$ \\
\hline redox & $75.6(18.2)$ & $94.5(22.7)$ & $127.5(18.8)$ & $83.1(13.0)$ & NS \\
\hline
\end{tabular}


Table 4. Soil \% organic ash-free dry mass carbon $(\mathrm{C})$, nitrogen $(\mathrm{N})$, and phosphorus $(\mathrm{P})$ for the four treatments: fresh, fresh $+\mathrm{P}$, salt, salt $+\mathrm{P}$. Soil elemental composition was measured at 57-d for surficial soil, and at 392 and 741-d at two depths (0-7.5 and 7.5$15 \mathrm{~cm}$ ) Treatments were compared using a two-way ANOVA. $P$-values less than 0.05 were considered significant. Values are reported as percentages ( \pm standard error).

\begin{tabular}{|c|c|c|c|c|c|}
\hline & \multicolumn{4}{|c|}{ treatment } & \multirow[b]{2}{*}{ Significance } \\
\hline & fresh & fresh + P & salt & salt $+\mathrm{P}$ & \\
\hline \multicolumn{6}{|l|}{ 57-d } \\
\hline$\% \mathrm{C}$ & $37.02(1.18)$ & $39.25(1.16)$ & $36.78(1.29)$ & $36.41(0.60)$ & NS \\
\hline$\% \mathrm{~N}$ & $2.17(0.00)$ & $2.43(0.01)$ & $2.22(0.10)$ & $2.38(0.06)$ & $\mathrm{P}^{*}$ \\
\hline$\% \mathrm{P}$ & $0.028(0.00)$ & $0.033(0.00)$ & $0.028(0.00)$ & $0.030(0.00)$ & $\mathrm{P}^{* *}$, salt $\times \mathrm{P}^{*}$ \\
\hline \multicolumn{6}{|l|}{ 392-d } \\
\hline \multicolumn{6}{|l|}{$0-7.5 \mathrm{~cm}$} \\
\hline$\% \mathrm{C}$ & $32.21(2.23)$ & $32.17(1.41)$ & $34.43(3.98)$ & $31.40(2.47)$ & NS \\
\hline$\% \mathrm{~N}$ & $1.83(0.09)$ & $1.79(0.06)$ & $1.78(0.18)$ & $1.82(0.15)$ & NS \\
\hline$\% \mathrm{P}$ & $0.03(0.01)$ & $0.04(0.00)$ & $0.03(0.00)$ & $0.03(0.00)$ & NS \\
\hline \multicolumn{6}{|l|}{$7.5-15 \mathrm{~cm}$} \\
\hline$\% \mathrm{C}$ & $32.68(2.23)$ & $31.84(1.41)$ & $34.51(3.98)$ & $32.01(2.47)$ & NS \\
\hline$\% \mathrm{~N}$ & $1.88(0.14)$ & $1.83(0.08)$ & $1.70(0.10)$ & $1.72(0.13)$ & NS \\
\hline$\% \mathrm{P}$ & $0.03(0.00)$ & $0.04(0.00)$ & $0.03(0.00)$ & $0.03(0.00)$ & $\mathrm{P}^{*}$ \\
\hline \multicolumn{6}{|l|}{ 742-d } \\
\hline \multicolumn{6}{|l|}{$0-7.5 \mathrm{~cm}$} \\
\hline$\% \mathrm{C}$ & $47.12(5.2)$ & $42.06(1.61)$ & $34.68(0.74)$ & $35.37(1.16)$ & salt** \\
\hline$\% \mathrm{~N}$ & $1.94(0.26)$ & $2.00(0.17)$ & $1.73(0.11)$ & $1.53(0.17)$ & NS \\
\hline$\% \mathrm{P}$ & $0.04(0.01)$ & $0.05(0.00)$ & $0.03(0.00)$ & $0.06(0.01)$ & $\mathrm{P}^{*}$ \\
\hline \multicolumn{6}{|l|}{$7.5-15 \mathrm{~cm}$} \\
\hline$\% \mathrm{C}$ & $47.91(4.91)$ & $43.19(1.22)$ & $35.92(0.78)$ & $36.57(0.86)$ & salt** \\
\hline$\% \mathrm{~N}$ & $2.10(0.34)$ & $1.93(0.19)$ & $2.02(0.14)$ & $1.56(0.22)$ & NS \\
\hline$\% \mathrm{P}$ & $0.06(0.02)$ & $0.04(0.00)$ & $0.03(0.01)$ & $0.04(0.000$ & NS \\
\hline
\end{tabular}


Table 5. Summarized responses to salinity and phosphorus (P) exposure at 57, 392 and 741 days. Data is broken up into two depth profiles for each parameter with the surface water/soil response above the porewater/deeper soil response. Responses are grouped into four categories: suppressed $(\downarrow)$, enhanced ( $\uparrow)$, no effect (NS), and interaction $(\leftrightarrow)$. Black spaces indicate that data is absent for that parameter. Response variables listed are surface water total organic carbon (TOC), dissolved organic C (DOC), ammonium $\left(\mathrm{NH}_{4}{ }^{+}\right.$), soluble reactive P (SRP), $\beta$-1,4-glucosidase, $\beta$-1,4cellobiosidase, soil respiration, microbial biomass, and root breakdown.

\begin{tabular}{|c|c|c|c|c|c|c|c|c|c|}
\hline & \multicolumn{3}{|c|}{57 days } & \multicolumn{3}{|c|}{392 days } & \multicolumn{3}{|c|}{741 days } \\
\hline & salt & $\mathrm{P}$ & $\begin{array}{c}\text { salt }+ \\
\text { P }\end{array}$ & salt & $\mathrm{P}$ & $\begin{array}{c}\text { salt + } \\
\text { P }\end{array}$ & salt & $\mathrm{P}$ & $\begin{array}{c}\text { salt }+ \\
\text { P }\end{array}$ \\
\hline$\triangle \mathrm{TOC}$ & NS & NS & $\downarrow$ & $\uparrow$ & $\uparrow$ & $\uparrow$ & $\uparrow$ & NS & NS \\
\hline DOC & $\begin{array}{c}\text { NS } \\
\downarrow\end{array}$ & $\begin{array}{c}\text { NS } \\
\uparrow\end{array}$ & $\begin{array}{l}\text { NS } \\
\leftrightarrow\end{array}$ & $\begin{array}{l}\uparrow \\
\uparrow\end{array}$ & $\begin{array}{l}\text { NS } \\
\text { NS }\end{array}$ & $\begin{array}{l}\text { NS } \\
\text { NS }\end{array}$ & $\begin{array}{l}\text { NS } \\
\uparrow\end{array}$ & $\begin{array}{l}\text { NS } \\
\uparrow\end{array}$ & $\begin{array}{l}\text { NS } \\
\text { NS }\end{array}$ \\
\hline $\mathrm{NH}_{4}^{+}$ & $\begin{array}{c}\mathrm{NS} \\
\uparrow\end{array}$ & $\begin{array}{c}\downarrow \\
\text { NS }\end{array}$ & $\begin{array}{l}\text { NS } \\
\text { NS }\end{array}$ & $\begin{array}{c}\text { NS } \\
\downarrow\end{array}$ & $\begin{array}{c}\uparrow \\
\mathrm{NS}\end{array}$ & $\begin{array}{l}\text { NS } \\
\text { NS }\end{array}$ & $\begin{array}{c}\mathrm{NS} \\
\uparrow\end{array}$ & $\begin{array}{c}\mathrm{NS} \\
\downarrow\end{array}$ & $\begin{array}{l}\text { NS } \\
\text { NS }\end{array}$ \\
\hline SRP & $\begin{array}{c}\text { NS } \\
\uparrow\end{array}$ & $\begin{array}{l}\text { NS } \\
\text { NS }\end{array}$ & $\begin{array}{l}\text { NS } \\
\text { NS }\end{array}$ & $\begin{array}{l}\text { NS } \\
\text { NS }\end{array}$ & $\begin{array}{l}\text { NS } \\
\text { NS }\end{array}$ & $\begin{array}{l}\text { NS } \\
\text { NS }\end{array}$ & $\begin{array}{l}\text { NS } \\
\text { NS }\end{array}$ & $\begin{array}{c}\text { NS } \\
\uparrow\end{array}$ & $\begin{array}{l}\text { NS } \\
\text { NS }\end{array}$ \\
\hline $\begin{array}{c}\beta-1,4- \\
\text { glucosidase }\end{array}$ & $\downarrow$ & NS & $\leftrightarrow$ & $\begin{array}{l}\downarrow \\
\downarrow\end{array}$ & $\begin{array}{l}\text { NS } \\
\text { NS }\end{array}$ & $\begin{array}{l}\leftrightarrow \\
\leftrightarrow\end{array}$ & $\begin{array}{c}\text { NS } \\
\downarrow\end{array}$ & $\begin{array}{l}\text { NS } \\
\text { NS }\end{array}$ & $\begin{array}{l}\text { NS } \\
\leftrightarrow\end{array}$ \\
\hline $\begin{array}{c}\beta-1,4- \\
\text { cellobiosidase }\end{array}$ & NS & NS & NS & $\begin{array}{c}\downarrow \\
\text { NS }\end{array}$ & $\begin{array}{l}\text { NS } \\
\text { NS }\end{array}$ & $\begin{array}{l}\leftrightarrow \\
\mathrm{NS}\end{array}$ & $\begin{array}{c}\text { NS } \\
\downarrow\end{array}$ & $\begin{array}{l}\text { NS } \\
\text { NS }\end{array}$ & $\begin{array}{c}\text { NS } \\
\downarrow\end{array}$ \\
\hline $\begin{array}{c}\text { soil } \\
\text { respiration }\end{array}$ & $\uparrow$ & NS & NS & $\begin{array}{c}\text { NS } \\
\downarrow\end{array}$ & $\begin{array}{l}\text { NS } \\
\text { NS }\end{array}$ & $\begin{array}{c}\text { NS } \\
\downarrow\end{array}$ & $\begin{array}{l}\text { NS } \\
\text { NS }\end{array}$ & $\begin{array}{l}\text { NS } \\
\text { NS }\end{array}$ & $\begin{array}{l}\text { NS } \\
\text { NS }\end{array}$ \\
\hline $\begin{array}{l}\text { microbial } \\
\text { biomass }\end{array}$ & & & & $\begin{array}{c}\text { NS } \\
\downarrow\end{array}$ & $\begin{array}{l}\text { NS } \\
\text { NS }\end{array}$ & $\begin{array}{c}\text { NS } \\
\downarrow\end{array}$ & $\begin{array}{l}\text { NS } \\
\text { NS }\end{array}$ & $\begin{array}{l}\text { NS } \\
\text { NS }\end{array}$ & $\begin{array}{l}\text { NS } \\
\text { NS }\end{array}$ \\
\hline $\begin{array}{c}\text { root } \\
\text { breakdown }\end{array}$ & & & & $\begin{array}{l}\text { NS } \\
\text { NS }\end{array}$ & $\begin{array}{l}\uparrow \\
\uparrow\end{array}$ & $\begin{array}{l}\text { NS } \\
\text { NS }\end{array}$ & & & \\
\hline
\end{tabular}




\section{FIGURES}

Figure 1. Microbial extracellular enzyme activities from surficial soils $(0-7.5 \mathrm{~cm})$ after 57 days and from soil at $0-7.5 \mathrm{~cm}$ and $7.5-15 \mathrm{~cm}$ depths at 392 and 741 days. Enzyme activities (phosphatase, arylsulfatase, $\beta$-1,4-glucosidase, and $\beta$-1,4-cellobiosidase) were assayed from experimental mesocosm wetlands exposed to four treatments: freshwater (fresh), freshwater with added phosphorus (fresh $+\mathrm{P})$, elevated salinity (salt), and elevated salinity with added phosphorus (salt $+\mathrm{P})$. Responses were compared using a two-way ANOVA followed by a Tukey HSD for comparison. P-values less than 0.05 were considered significant. Lowercase significance indicators $(a, b)$ are reported within the $0-7.5 \mathrm{~cm}$ depth and uppercase significance indicators $(\mathrm{A}, \mathrm{B})$ are reported within the 7.5-15 cm depth.

Figure 2. Soil respiration rates at (a) 57-d, (b) 392-d, and (c) 741-d. Respiration was measured at 0-7.5 cm samples on all dates and 7.5-15 cm samples on the 392 and 741-d events. For each date and soil depth the four treatments fresh, fresh $+\mathrm{P}$, salt, salt $+\mathrm{P}$ were compared using a two-way ANOVA followed by a Tukey HSD for comparison. Pvalues less than 0.05 were considered significant.

Figure 3. Soil microbial biomass at (a) 392-d and (b) 741-d. Soil microbial biomass was measured at 0-7.5 $\mathrm{cm}$ and 7.5-15 $\mathrm{cm}$ samples on the 392 and 741-d events. For each date and soil depth the four treatments fresh, fresh $+\mathrm{P}$, salt, salt $+\mathrm{P}$ were compared using a two-way ANOVA followed by a Tukey HSD for comparison. P-values less than 0.05 
were considered significant. Uppercase significance indicators (A, B) are reported within the $7.5-15 \mathrm{~cm}$ depth.

Figure 4. The proportion of mass loss during $356 \mathrm{~d}$ incubation of root litter within the soil at 0-7.5 and 7.5-15.0 cm depths. Enzyme activities for phosphatases (b), arylsulfatase (c), $\beta$-1,4-glucosidase (d), and $\beta$-1,4-cellobiosidase (e) are reported in $\mu$ mol g $^{-1} \mathrm{~h}^{-1}$ measured on root litter upon retrieval at 356 days. Enzyme activity (phosphatase, arylsulfatase, $\beta$ 1,4-glucosidase, and $\beta$-1,4-cellobiosidase) were calculated from experimental mesocosm wetlands exposed to four treatments: freshwater (fresh), freshwater with added phosphorus (fresh $+\mathrm{P}$ ), elevated salinity (salt), and elevated salinity with added phosphorus $($ salt $+\mathrm{P})$. Responses were compared using a two-way ANOVA followed by a Tukey HSD for comparison. P-values less than 0.05 were considered significant. Lowercase significance indicators $(\mathrm{a}, \mathrm{b})$ are reported within the $0-7.5 \mathrm{~cm}$ depth and uppercase significance indicators (A, B) are reported within the 7.5-15 cm depth. 
Figure 1.
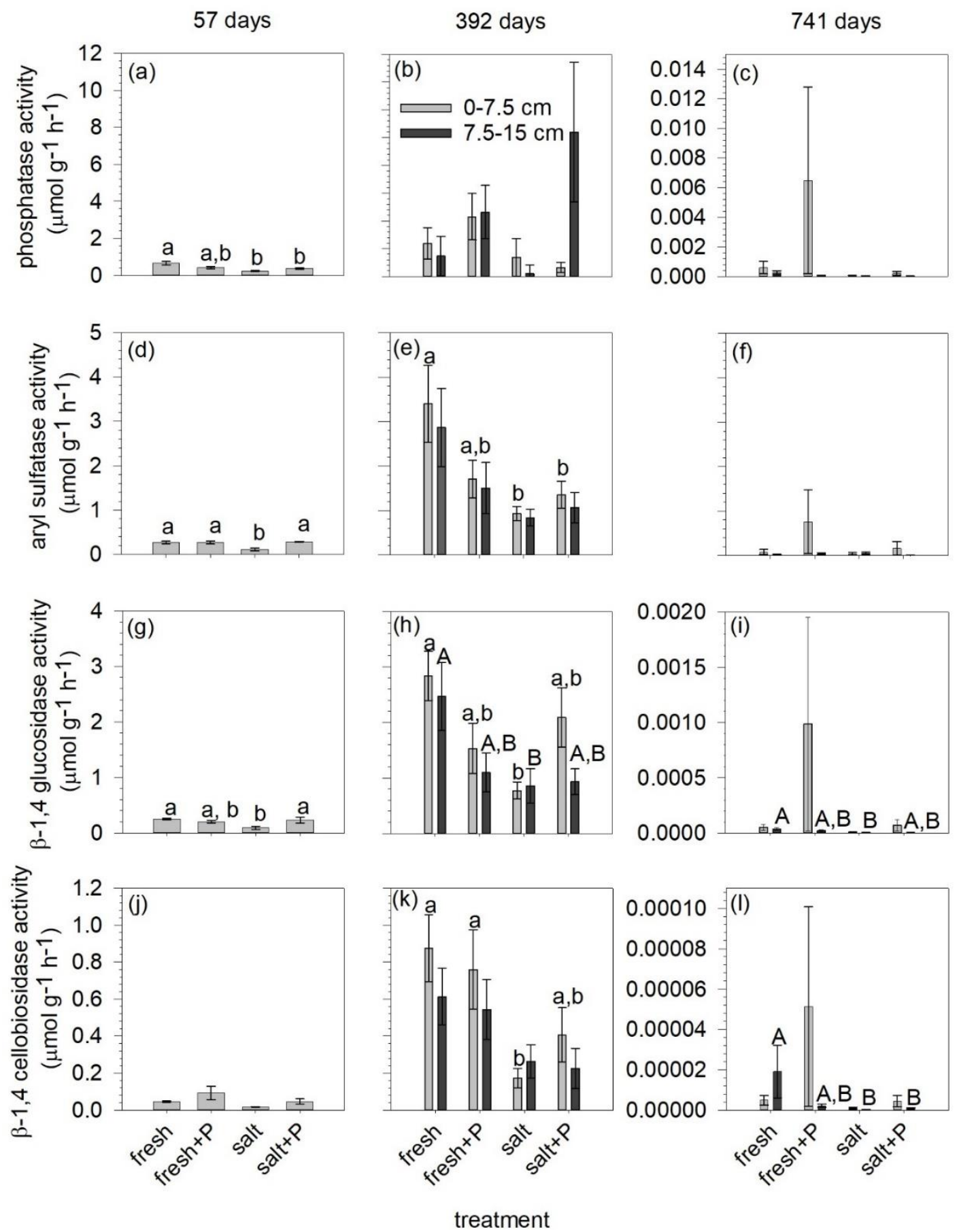
Figure 2.
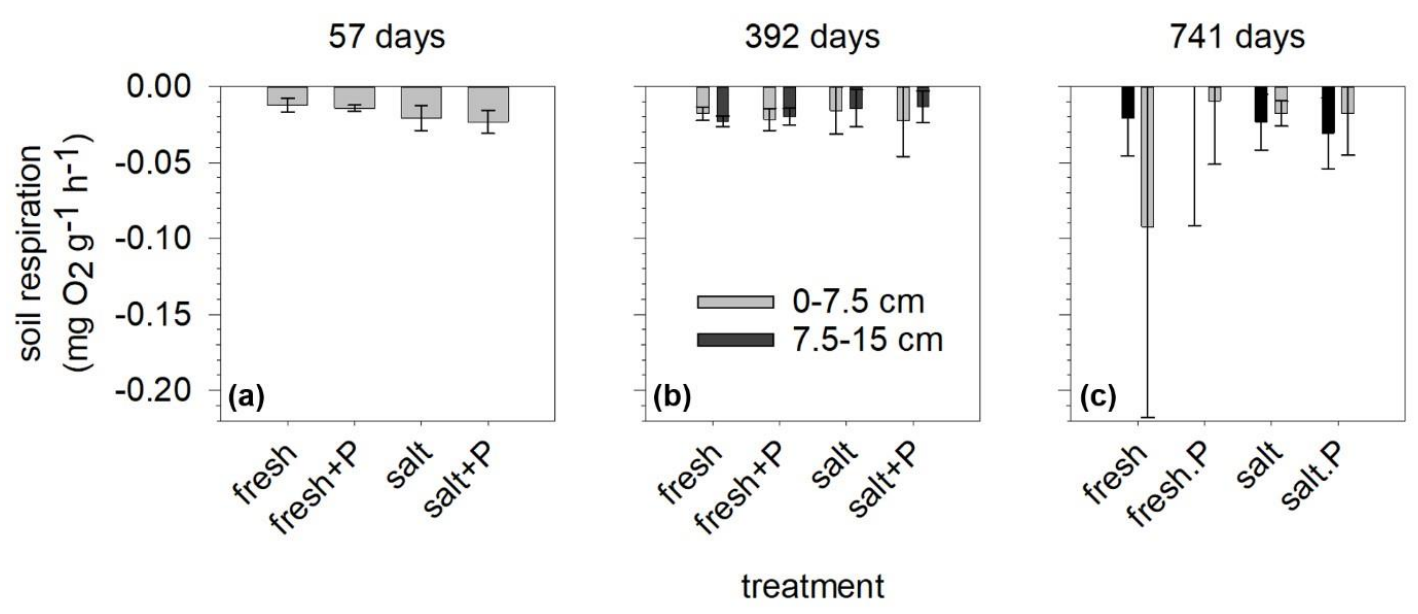
Figure 3.

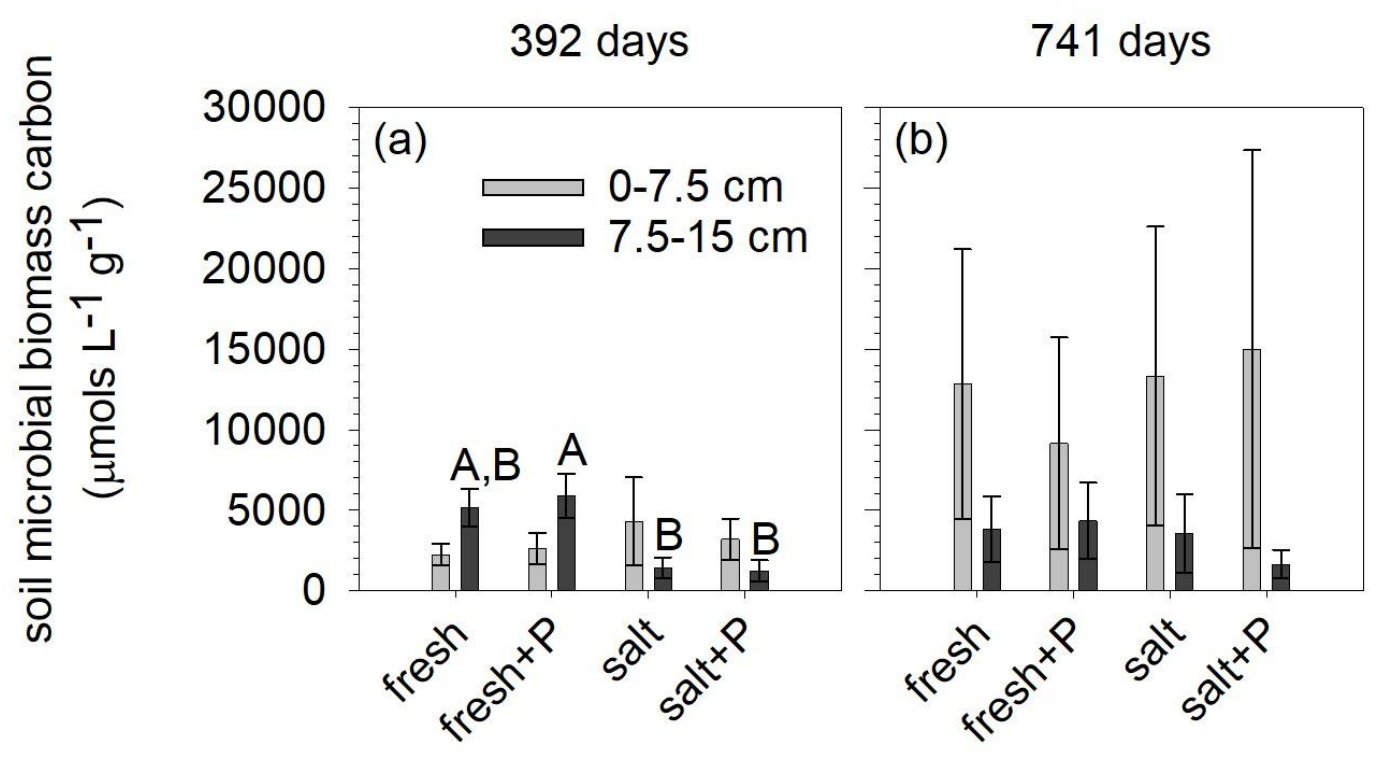


Figure 4.
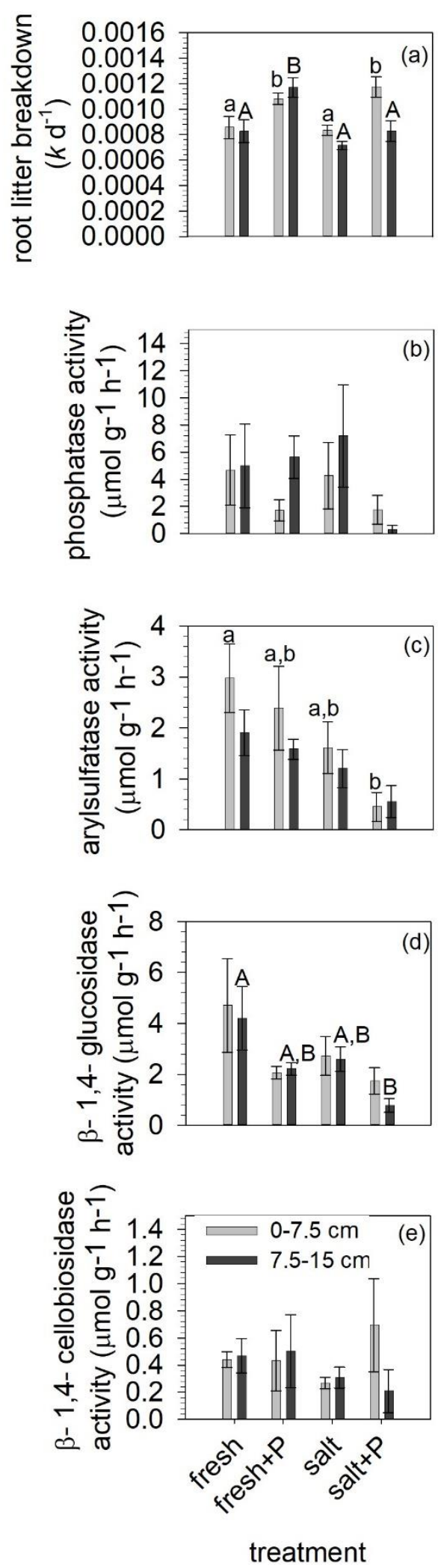
SUPPLEMENTAL INFORMATION. Full statistical results for the ANOVA test on phosphatase, arylsulfatase, $\beta$-1,4-glucosidase, $\beta$ - 1,4 cellobiosidase, respiration, and microbial biomass carbon measured at 57,392, and 741 days.

\begin{tabular}{|c|c|c|c|c|c|c|}
\hline & phosphatase & arylsulfatase & $\beta$-1,4-glucosidase & $\begin{array}{l}\beta-1,4- \\
\text { cellobiosidase }\end{array}$ & respiration & $\begin{array}{l}\text { microbial biomass } \\
\text { carbon }\end{array}$ \\
\hline \multicolumn{7}{|l|}{57 days } \\
\hline salt & $F_{(1,8)}=15.29$ & $F_{(1,8)}=7.17$ & $F_{(1,8)}=3.83$ & $F_{(1,8)}=3.58$ & $F_{(1,8)}=6.14$ & \\
\hline \multirow{2}{*}{$\mathrm{P}$} & $\begin{array}{r}\boldsymbol{P}<\mathbf{0 . 0 1} \\
F_{(1,8)}=0.52\end{array}$ & $\begin{array}{r}P=0.03 \\
F_{(1,8)}=10.64\end{array}$ & $\begin{aligned} P & =0.09 \\
F_{(1.8)} & =1.90\end{aligned}$ & $\begin{aligned} P & =0.10 \\
F_{(1.8)} & =3.89\end{aligned}$ & $\begin{aligned} \boldsymbol{P} & =\mathbf{0 . 0 4} \\
F_{(1.8)} & =0.44\end{aligned}$ & \\
\hline & $P=0.49$ & $P=0.01$ & $P=0.21$ & $P=0.08$ & $P=0.52$ & \\
\hline salt $* \mathrm{P}$ & $\begin{array}{r}F_{(1,8)}=8.82 \\
P=0.02\end{array}$ & $F_{(1,8)}=10.53$ & $\begin{aligned} F_{(1,8)} & =7.30 \\
P & =0.03\end{aligned}$ & $\begin{array}{r}F_{(1,8)}=0.22 \\
P=0.65\end{array}$ & $F_{(1,8)}=0.01$ & \\
\hline \multicolumn{7}{|l|}{392 days } \\
\hline \multicolumn{7}{|l|}{$0-7.5 \mathrm{~cm}$} \\
\hline salt & $\begin{aligned} F_{(1,20)} & =3.58 \\
P & =0.07\end{aligned}$ & $\begin{aligned} F_{(1,20)} & =7.54 \\
P & =0.01\end{aligned}$ & $\begin{aligned} F_{(1,20)} & =3.19 \\
P & =0.09\end{aligned}$ & $\begin{array}{r}F_{(1,20)}=10.81 \\
P<0.01\end{array}$ & $\begin{aligned} F_{(1,20)} & =0.01 \\
P & =0.93\end{aligned}$ & $\begin{aligned} F_{(1,20)} & =0.50 \\
P & =0.49\end{aligned}$ \\
\hline \multirow[t]{2}{*}{$\mathrm{P}$} & $F_{(1,20)}=0.24$ & $F_{(1,20)}=1.52$ & $F_{(1,20)}=0.00$ & $F_{(1,20)}=0.14$ & $F_{(1,20)}=0.77$ & $F_{(1,20)}=0.39$ \\
\hline & $P=0.63$ & $P=0.23$ & $P=0.99$ & $P=0.72$ & $P=0.39$ & $P=0.54$ \\
\hline \multirow[t]{2}{*}{ salt * P } & $F_{(1,20)}=1.16$ & $F_{(1,20)}=4.24$ & $F_{(1,20)}=9.71$ & $F_{(1,20)}=1.19$ & $F_{(1,20)}=0.05$ & $F_{(1,20)}=0.18$ \\
\hline & $P=0.29$ & $P=0.05$ & $P=0.01$ & $P=0.29$ & $P=0.82$ & $P=0.68$ \\
\hline \multicolumn{7}{|l|}{$7.5-15 \mathrm{~cm}$} \\
\hline \multirow[t]{2}{*}{ salt } & $F_{(1,20)}=0.64$ & $F_{(1,20)}=4.84$ & $F_{(1,20)}=4.88$ & $F_{(1,20)}=6.41$ & $F_{(1,20)}=4.38$ & $F_{(1,20)}=15.73$ \\
\hline & $P=0.43$ & $P=0.04$ & $P=0.04$ & $P=0.02$ & $P=0.05$ & $P<0.01$ \\
\hline \multirow[t]{2}{*}{$\mathrm{P}$} & $F_{(1,20)}=5.36$ & $F_{(1,20)}=1.03$ & $F_{(1,20)}=2.59$ & $F_{(1,20)}=0.17$ & $F_{(1,20)}=0.34$ & $F_{(1,20)}=0.63$ \\
\hline & $P=0.03$ & $P=0.32$ & $P=0.12$ & $P=0.69$ & $P=0.56$ & $P=0.44$ \\
\hline \multirow[t]{2}{*}{ salt $* \mathrm{P}$} & $F_{(1,20)}=1.50$ & $F_{(1,20)}=2.02$ & $F_{(1,20)}=3.24$ & $F_{(1,20)}=0.02$ & $F_{(1,20)}=0.10$ & $F_{(1,20)}=1.74$ \\
\hline & $P=0.23$ & $P=0.17$ & $P=0.87$ & $P=0.90$ & $P=0.75$ & $P=0.20$ \\
\hline \multicolumn{7}{|l|}{741 days } \\
\hline \multicolumn{7}{|l|}{$0-7.5 \mathrm{~cm}$} \\
\hline \multirow[t]{2}{*}{ salt } & $F_{(1,19)}=1.23$ & $F_{(1,19)}=0.85$ & $F_{(1,19)}=1.05$ & $F_{(1,19)}=1.11$ & $F_{(1,19)}=0.57$ & $F_{(1,19)}=0.01$ \\
\hline & $P=0.28$ & $P=0.37$ & $P=0.32$ & $P=0.31$ & $P=0.46$ & $P=0.94$ \\
\hline \multirow[t]{2}{*}{$\mathrm{P}$} & $F_{(1,19)}=0.75$ & $F_{(1,19)}=1.00$ & $F_{(1,19)}=0.88$ & $F_{(1,19)}=0.84$ & $F_{(1,19)}=0.18$ & $F_{(1,19)}=0.06$ \\
\hline & $P=0.40$ & $P=0.33$ & $P=0.36$ & $P=0.37$ & $P=0.68$ & $\mathrm{P}=0.81$ \\
\hline \multirow[t]{2}{*}{ salt $* \mathrm{P}$} & $F_{(1,19)}=0.75$ & $F_{(1,19)}=0.53$ & $F_{(1,19)}=0.74$ & $F_{(1,19)}=0.68$ & $F_{(1,19)}=0.61$ & $F_{(1,19)}=0.04$ \\
\hline & $P=0.40$ & $P=0.48$ & $P=0.40$ & $P=0.42$ & $P=0.45$ & $P=0.84$ \\
\hline \multicolumn{7}{|l|}{$7.5-15 \mathrm{~cm}$} \\
\hline \multirow[t]{2}{*}{ salt } & $F_{(1,19)}=0.32$ & $F_{(1,19)}=0.04$ & $F_{(1,19)}=8.72$ & $F_{(1,19)}=8.53$ & $F_{(1,19)}=1.24$ & $F_{(1,19)}=1.35$ \\
\hline & $P=0.09$ & $P=0.85$ & $P=0.01$ & $P=0.01$ & $P=0.28$ & $P=0.26$ \\
\hline \multirow[t]{2}{*}{$\mathrm{P}$} & $F_{(1,19)}=1.88$ & $F_{(1,19)}=0.52$ & $F_{(1,19)}=0.67$ & $F_{(1,19)}=2.11$ & $F_{(1,19)}=2.25$ & $F_{(1,19)}=0.51$ \\
\hline & $P=0.19$ & $P=0.48$ & $P=0.42$ & $P=0.16$ & $P=0.15$ & $P=0.48$ \\
\hline \multirow[t]{2}{*}{ salt $* \mathrm{P}$} & $F_{(1,19)}=2.24$ & $F_{(1,19)}=2.74$ & $F_{(1,19)}=1.33$ & $F_{(1,19)}=3.95$ & $F_{(1,19)}=2.44$ & $F_{(1,19)}=0.12$ \\
\hline & $P=0.15$ & $P=0.11$ & $P=0.26$ & $P=0.06$ & $P=0.14$ & $P=0.73$ \\
\hline
\end{tabular}




\section{CHAPTER III}

EFFECTS OF EXPERIMENTAL SALTWATER PULSES IN COASTAL WETLANDS: QUANTIFYING CHANGES IN MICROBIALLY-MEDIATED ORGANIC MATTER BREAKDOWN 
Title: Effects of experimental saltwater pulses in coastal wetlands: quantifying changes in microbially-mediated organic matter breakdown

Shelby Servais ${ }^{1 *}$, John S. Kominoski ${ }^{1}$, Carlos Coronado-Molina ${ }^{2}$, Laura Bauman ${ }^{1}$, Stephen E. Davis ${ }^{3}$, Evelyn E. Gaiser ${ }^{1}$, Stephen Kelly ${ }^{2}$, Christopher Madden², Viviana Mazzei $^{1}$, David Rudnik ${ }^{4}$, Fabiola Santamaria ${ }^{2}$, Fred H. Sklar ${ }^{2}$, Joseph Stachelek ${ }^{2,5}$, Tiffany G. Troxler ${ }^{1}$, and Benjamin J. Wilson ${ }^{1}$

${ }^{1}$ Department of Biological Sciences and Southeast Environmental Research Center, Florida International University, Miami, Florida 33199

${ }^{2}$ Everglades Systems assessment section, South Florida Water Management District, West Palm Beach, Florida 33406

${ }^{3}$ Everglades Foundation, Palmetto Bay, Florida 33157

${ }^{4}$ Everglades National Park, Homestead, Florida 33034

${ }^{5}$ Michigan State University, East Lansing, Michigan 48824 USA

*Corresponding author: sserv005@fiu.edu 


\section{ABSTRACT}

Coastal wetlands are exposed to saltwater intrusion (SWI) from storms and sea level rise, leading to uncertainties for the fate of belowground organic matter. How soil microbial extracellular enzyme activities (EEAs), which drive organic matter breakdown, respond to SWI are unclear. Our objectives were to quantify changes in microbial EEAs and root breakdown in freshwater and brackish soils exposed to pulsed SWI. We simulated SWI by monthly in situ dosing of artificial seawater in chambers $(n=6)$ in freshwater and brackish wetlands to achieve targeted porewater salinities that were twice ambient ( 5 and 20 parts per thousand, respectively). We incubated (0-30 cm soil depth) Eleocharis cellulosa and Cladium jamaicense root litter in freshwater and C. jamaicense root litter in brackish chambers and collected the root litter at multiple time intervals for approximately 2 years. After each collection, we analyzed the remaining root litter for microbial EEAs, elemental stoichiometric ratios (C:nitrogen, N; C:phosphorus, $\mathrm{P}$ ), and breakdown rates $(k)$. Short-term exposure to elevated salinity pulses increased root litter $k$ by 1.25 -fold in the brackish marsh. However, long-term $k$ in brackish wetlands, and both short- and long-term $k$ in freshwater wetlands was not affected by pulses of saltwater. Enzyme activities varied over time and were primarily non-responsive to saltwater pulses. Our results indicate that microbial communities in reduced soils of coastal wetlands have low sensitivity to pulsed SWI and are not direct sources of C loss. However, microbial communities continuously exposed to SWI and those in less reduced soils may be sources of C loss. Saltwater dosing experiments provide insights into critical changes in peat integrity and degradation mechanisms. 


\section{INTRODUCTION}

Organic matter breakdown is a fundamental ecosystem process that integrates carbon (C) and nutrient cycling (Hoorens et al. 2003). Carbon cycling is typically measured at large ecosystem-scales, yet the fundamental processes occur at the microbial and biochemical scale (Sinsabaugh and Shah 2012). Studies focused on the underlying mechanisms controlling organic matter breakdown inform ecosystem-level processes and are critical to predicting how biogeochemical cycling will be altered by climate change and land management (Sinsabaugh et al. 2002). Understanding the fundamental mechanisms of how breakdown of organic matter - mediated by microbial communities is affected by environmental changes will help improve predictions of ecosystem responses to climate change.

In coastal wetlands, the historical balance between organic matter inputs and decay has promoted soil accretion (Nyman et al. 2006, McKee 2011). The slow breakdown of organic matter, because of long hydroperiod or water-logging, enables coastal wetlands to store vast amounts of C (Mitsch and Gosselink 2007). Inundated soils, low in oxygen, break down detritus at a slower rate than oxygenated soils (Stainer et al. 1986). Breakdown of plant litter and soil organic matter in wetlands determines the rates of nutrient cycling and soil accretion or subsidence (Newman et al. 2001, Pisani et al. 2017). A commonly used approach used to assess breakdown processes and rates in wetlands is the litterbag method (van der Valk et al. 1991, Brinson 1977). Although this method helps quantify rates of organic matter breakdown at small scales, litterbags alone are unable to provide information on the biogeochemical mechanisms behind breakdown (Sinsabaugh et al. 2002). Therefore, approaches that combine measuring extracellular 
enzyme activities (EEAs) with litterbags are particularly effective at providing information on microbially-mediated mechanisms contributing to ecosystem function (Kang et al. 1999, Sinsabaugh et al. 2000).

Extracellular enzymes within soils play a critical role in determining the rate of organic matter breakdown (Schimel and Weintraub 2003). Microbial decomposers release extracellular enzymes into the environment to catalyze the processing of highmolecular-weight organic material into easily assimilable units (Dick et al. 1994). Extracellular enzymes enable microbial communities within the soil to obtain $\mathrm{C}$ and limiting nutrients (Burns 1982). Extracellular enzymes such as phosphatase, arylsulfatase, leucine aminopeptidase $\beta$-1,4-glucosidase, and $\beta$-1,4-cellobiosidase have been studied for their role in phosphorus (P), sulfur (S), nitrogen (N) and C cycles (Burns 1978, Sinsabaugh and Linkins 1988, Wright and Reddy 2001). The relationship between EEAs and the breakdown of organic material in wetlands is well documented (Jackson et al. 1995, Freeman et al. 1996, Kang et al. 1999, Schimel and Weintraub 2003). However, few have tested how changing environmental conditions may alter the relationship between enzyme activities and the breakdown of organic matter (Allison and Vitousek 2004, Rejmánková and Sirová 2007).

With accelerating rates of sea-level rise, coastal wetlands are increasingly threatened by exposure to SWI (White and Kaplan 2017, Dessu et al. 2018). Saltwater intrusion into wetlands can increase microbial breakdown and stimulate organic $\mathrm{C}$ loss (Craft 2007, Chambers et al. 2011, Weston et al. 2011) and associated inundation can also change soil ionic properties and redox conditions (Weston et al. 2006). Therefore, it is necessary to consider both stoichiometric and thermodynamic limitations important to 
understanding effects of SWI on the microbial processing of organic matter (Helton et al. 2015). Few studies have investigated the impact that stressors, like elevated salinity, can have on soil microbial activities and the breakdown of organic material (Morrissey et al. 2014, Neubauer et al. 2013, Servais et al. in review). Previous work in Everglades soils found that long-term sustained exposure to presses of saltwater resulted in suppression of enzyme potential that was maintained even after two years of exposure (Servais et al. in review).

We used the Florida Coastal Everglades as a model system to investigate the effects of pulsed SWI on the processing of organic material. The Everglades is particularly vulnerable to SWI because of declines in seasonal freshwater delivery needed to maintain ecosystem development (Odum et al. 1995), a naturally low topographic incline, and increased rates of sea level rise (Ross et al. 2000). The Everglades has hydrologic and vegetation gradients from freshwater to brackish marshes, and, as sea level rises, salinity will increase in both areas because of SWI (Pearlstine et al. 2010). One particularly concerning phenomenon that has been observed in the Everglades and other coastal wetlands is rapid subsidence of organic peat soils referred to as "peat collapse" (Wanless and Vlaswinkel 2005). Therefore, investigating how SWI alters the microbially-mediated processing of organic matter in coastal wetlands is critical to understanding the biogeochemical mechanisms behind peat collapse. Quantifying how changes in microbial EEAs affect the breakdown of organic matter with enhanced SWI are crucial for predicting microbially-mediated $\mathrm{C}$ loss in coastal wetlands (Chambers et al. 2015, 2016). 
Our objective was to test how both short- and long-term exposure to pulses of salinity affect microbial activities and in situ root litter breakdown rates in freshwater and brackish marshes of Everglades National Park. We tested short- and long-term effects of saltwater pulses on porewater chemistry, microbial EEAs associated with bulk soil and root litter, root litter and soil elemental stoichiometry, and root litter breakdown rates $(k)$. We used a path analysis to identify how changes in $k$ were explained by differences in porewater chemistry, EEAs, and organic matter stoichiometry. We hypothesized there would be a direct inhibitory effect of increased salinity on EEAs and indirect effects of salinity through changes in porewater chemistry (increased soluble reactive $\mathrm{P}$, total inorganic N, sulfate, and dissolved organic C (DOC) that would result in increased $k$ with higher salinity. We predicted the primary mechanism for changes in $k$ to occur indirectly through changes in EEAs and litter stoichiometry that collectively affect $k$ (Figure 2).

\section{METHODS}

Study Site

We established two study sites (one freshwater, one brackish) within Everglades National Park, Florida, USA. The freshwater site (25 26'6.11" N, 8046 '50.78” W) had not been exposed to SWI (Wilson et al. in prep) and was dominated by Eleocharis cellulosa and Cladium jamaiscense macrophytes. The freshwater site had a longer hydroperiod and remained inundated for approximately 11 months each year (Wilson et al. in prep). The brackish site (25 13' $\left.13.38^{\prime \prime} \mathrm{N}, 8050^{\prime} 36.66^{\prime} \mathrm{W}\right)$ had already been exposed to SWI and was dominated by $C$. jamaicense with some dwarf Rhizophora 
mangle and Conocarpus erectus present. The brackish site was not tidally influenced and experienced distinct periods of dry-down (Wilson et al. in prep).

In September 2014, we installed 12 experimental polycarbonate chambers (1.4 m diameter) along with a constructed boardwalk ( $80 \mathrm{~m}$ long) at both freshwater and brackish sites. We embedded each chamber $30 \mathrm{~cm}$ within the soil. Each chamber had a series of $10-\mathrm{cm}$ holes drilled in the sides to facilitate water exchange, a rotating collar allowed for these openings to be closed during the dosing event (Figure1). Chambers were sealed before dosing events and re-opened after $24 \mathrm{~h}$. Six chambers at each site were designated as ambient controls, and six were designated as saltwater treatments. The saltwater treatments were established downstream from the topographic flow to ensure minimal contamination between treatment and control chambers.

\section{Pulsed saltwater dosing}

We began experimental pulsed additions of saltwater in October 2014 that continued monthly through November 2016. Monthly pulsed saltwater dosing consisted of additions of Instant Ocean ${ }^{\circledR}$ mixed with water obtained at or near each study site to the six treatment chambers at each site. We dosed the equivalent amount of site water to the six control chambers at each site. Dosing mixtures for saltwater treatments were adjusted based on ambient conditions at the study site each month to account for seasonal changes in water level and surface water salinity at each site. We used a mass balance equation for the volume of dose-water to be added to each mesocosm as described in Stachelek et al. (in review) to achieve a two-fold increase in ambient porewater salinity. The target porewater salinity for the brackish site was $20 \mathrm{ppt}$, and the salinity of the dosing solution 
ranged from 30.7-65.0 ppt (Stachelek et al. in review). The target porewater salinity for the freshwater site was $5 \mathrm{ppt}$, and the salinity of the dosing solution ranged from 26.8 to $68.0 \mathrm{ppt}$.

Before each dosing event, chamber collars were rotated to seal the openings. The dosing solution was pumped through a hose and sprinkled onto the surface of each treatment chamber. We were careful to not apply the dosing mixture directly on the vegetation and rinsed plants off immediately following dosing. We kept each chamber sealed each for 24 hours to allow the dosing water to mix with the porewater. Afterward, we rotated the chamber collars and left them open to the environment to minimize chamber effects.

\section{Porewater physicochemistry}

Three porewater sippers with an air stone (4-cm long x 1-cm diameter) were inserted to a $15-\mathrm{cm}$ depth within each chamber. Porewater was collected $24 \mathrm{~h}$ after each mostly dosing event using a $60-\mathrm{ml}$ syringe by placing suction on the sipper and evacuating at least one sipper volume before sampling. Water was field filtered $(0.7-\mu \mathrm{M}$ GFF) into new plastic bottles. Porewater was analyzed for temperature, salinity, and $\mathrm{pH}$ immediately after extraction using a YSI Model 600 XL (Xylem, Inc., Yellow Springs, OH, USA).

Soluble reactive phosphorus (SRP), total dissolved $\mathrm{P}$ (TDP), and total dissolved $\mathrm{N}$ (TDN) was analyzed at the South Florida Water Management District Water Quality Laboratory on an Alpkem Flow Solution Analyzer (OI Analytical, College Station, TX, USA) following Standard Method 4500-P F (SRP) and Solorzano and Sharp (1980, 
TDP). Ammonium $\left(\mathrm{NH}_{4}{ }^{+}\right)$, and dissolved inorganic N (DIN) was analyzed at the South Florida Water Management District Water Quality Laboratory on a Lachat Flow Injection Analyzer (Lachat Instruments, Loveland, CO, USA) following Standard Method 4500$\mathrm{NH} 3 \mathrm{H}\left(\mathrm{NH}_{4}{ }^{+}\right)$or Standard Method $4500-\mathrm{N} \mathrm{C}(\mathrm{DIN})$. Sulfate $\left(\mathrm{SO}_{4}{ }^{2-}\right)$ was analyzed using an ion chromatograph (Metrohm 881, Riverview, FL, USA). Dissolved organic C (DOC) was analyzed using a Shimadzu TOC-L analyzer (Shimadzu Scientific Instruments, Columbia, MD, USA) following Standard Method 5310 B. Alkalinity and pH were determined using an automated titrator (Metrohm 855 Titrator, Herisau, Switzerland) following Standard Method 2320 B (Alkalinity) and a modification to Standard Method $4500 \mathrm{H}^{+} \mathrm{B}(\mathrm{pH})$. Chloride $\left(\mathrm{Cl}^{-}\right)$and sulfate $\left(\mathrm{SO}_{4}{ }^{2-}\right)$ were measured using a Metrohm 881 Compact IC Pro System (Metrohm, Riverview, FL, USA) following Standard Method 4110 B.

\section{Root litter breakdown rates}

In October 2014, we collected live E. cellulosa and C. jamaicense from the freshwater and brackish sites and the Water Conservation Area 3A (25 46' 09.3" N, 80 $\left.40^{\prime} 22.6^{\prime \prime} \mathrm{W}\right)$. We rinsed the roots of sediment and dried in an oven at $60^{\circ} \mathrm{C}$. Litter bags $(10 \times 30 \mathrm{~cm}$, containing three depth compartments $)$ were constructed from 1-mm nylon mesh. We added with a known amount $(2.93 \pm 0.02 \mathrm{~g})$ of the dried root material to each mesh compartment. Litter bags deployed at the brackish site were filled with roots of $C$. jamaicense, to represent the dominant vegetation. Litter bags used at the freshwater site were filled with either of E. cellulosa or C. jamaicense roots; three control chambers were assigned to E. cellulosa, and three control and treatment chambers were assigned 
with $C$. jamaicense to represent the dominant vegetation. Five litter bags were incubated within each chamber at the freshwater site, and six bags were incubated within each chamber at the brackish site in November 2014. Litter bags were inserted vertically into the soil profile so that the three compartments represented $0-10,10-20$, and $20-30 \mathrm{~cm}$ depths. We retrieved litter bags after 30, 105, 194, 383, 576 and 740-d with the 383-d sampling occurring only at the brackish site. Directly following removal from the field, samples were placed on ice and transported to the laboratory for extracellular enzyme analysis. Oven-dried $\left(40^{\circ} \mathrm{C}\right.$ for $\left.24 \mathrm{~h}\right)$ root litter was weighed to obtain dry mass and combusted at $550^{\circ} \mathrm{C}$ for four hours to estimate ash-free dry mass (AFDM) remaining. Decay rates were calculated for the first 30-d and final 740-d collections using the first order, exponential loss decay model, $\mathrm{M}_{\mathrm{t}}=\mathrm{M}_{\mathrm{o}} \mathrm{e}^{-\mathrm{kt}}$, where $\mathrm{M}_{\mathrm{t}}$ is the AFDM at time $\mathrm{t}$ (30-d and 740-d), $\mathrm{M}_{\mathrm{o}}$ is original dry mass, and $k$ is degradation coefficient ( $\mathrm{d}^{-1}$; Olson 1963). We used all the collected data to estimate $k$ at 740-d.

\section{Root litter elemental content and stoichiometry}

To follow nutrient accumulation or loss we measured root elemental C, N and P content and their elemental ratios. We calculated the absolute mass as the product of dry mass remaining and C, N or P content of litter following Davis et al. (2003). After retrieving bags from the field, root litter was gently washed of adhering soil dried to constant weight at $60^{\circ} \mathrm{C}$ and weighed. Subsamples of root litter were ground to a homogeneous powder using a ball mill (SPEX CertiPrep, Metuchen, New Jersey) and analyzed for $\% \mathrm{C}, \% \mathrm{~N}$, and $\% \mathrm{P}$ content. Root tissue $\% \mathrm{C}$ and $\% \mathrm{~N}$ were analyzed using a Carlo Erba Elemental Analyzer (Carlo Erba, Milan, Italy), and \%P was determined acid 
digestion of ground, combusted samples that were analyzed spectrophotometrically (Solorazano and Sharp 1980). Molar ratios (C:N, C:P) were calculated for all root litter.

\section{Extracellular enzyme potential}

We measured EEAs for each root collection and on the year two soil sample collection. We measured the fluorometric activities of extracellular acid phosphatase, arylsulfatase, $\beta$-1,4-glucosidase, $\beta$-1,4-cellobiosidase, and leucine aminopeptidase using previously described methods (Saiya-Cork et al. 2002). Briefly, sub-samples were taken (approximately $1 \mathrm{~g}$ ) from each root litter bag compartment, homogenized in $60 \mathrm{~mL}$ of 50 $\mathrm{mM}$ of sodium acetate buffer, and loaded onto a 96-well plate with the appropriate substrate (Servais et al., in review). Fluorescence was read at $365 \mathrm{~nm}$ excitation and 450 nm emission using a Synergy H1 microplate reader (BioTek, Winooski, Vermont, USA). We incorporated blanks and controls within each microplate to account for autofluorescence and quenching.

\section{Bulk soil properties}

In addition to root collections, we collected soil cores $(2.3 \mathrm{~cm}$ diameter $\times 30 \mathrm{~cm}$ deep) after two-years of experimental dosing. We collected one core from each chamber and sectioned it into three depths $(0-10,10-20,20-30 \mathrm{~cm})$. We analyzed soil at each depth section for extracellular enzyme potential and $\% \mathrm{C}, \% \mathrm{~N}$, and $\% \mathrm{P}$, as well as $\mathrm{C}: \mathrm{N}, \mathrm{C}: \mathrm{P}$, and $\mathrm{N}: \mathrm{P}$ molar ratios, as described above. To estimate the mass of the living microorganisms within the soil, we determined the microbial biomass $\mathrm{C}$ from soil subsamples from the 010 and 10-20 cm depths using chloroform fumigation and potassium sulfate extraction 
methods following Vance et al. (1987). Dissolved organic C samples were analyzed with a Shimadzu 5000 TOC Analyzer (Shimadzu Scientific Instruments, Columbia, MD, USA). We calculated microbial biomass $\mathrm{C}$ as the difference in DOC between nonfumigated and fumigated samples.

\section{Data analyses}

We calculated the average salinity, $\mathrm{pH}$, alkalinity, DOC, TDN, $\mathrm{NH}_{4}^{+}, \mathrm{SRP}, \mathrm{TDP}$, $\mathrm{SO}_{4}{ }^{2-}, \mathrm{HS}^{-}$, temperature, soil redox measured $24 \mathrm{~h}$ after each dosing event for two-years $(n=24)$ for each site. We compared the average biogeochemical parameters using a Welch's two-sample $t$-test $(\alpha=0.05)$. We compared enzyme potential (acid phosphatase, alkaline phosphatase, arylsulfatase, $\beta$-1,4-glucosidase, $\beta$-1,4-cellobiosidase, and leucine aminopeptidase), root liter proportion AFDM remaining, and root litter stoichiometry $(\% \mathrm{C}, \% \mathrm{~N}, \% \mathrm{P}, \mathrm{C}: \mathrm{N}, \mathrm{C}: \mathrm{P}, \mathrm{N}: \mathrm{P})$ among control and treatment chambers using a two-way repeated measure analysis of variance (rmANOVA). For the brackish site, treatment $(n=$ $2)$ and date $(n=6)$ were fixed factors, while the chamber was a random factor. For the freshwater site treatment $(n=2)$, date $(n=5)$, and species of the litter were fixed factors, while the chamber was a random factor. We analyzed each soil depth (0-10, 10-20, and 20-30 cm) separately. All two-way rmANOVA analyses were assessed for temporal differences using the least squared means (LSMEANS), with the date as a model effect (R package lsmeans, Lenth 2017). All proportion data (proportion AFDM root litter remaining, $\% \mathrm{C}, \% \mathrm{~N}$, and $\% \mathrm{P}$ ) were transformed by taking the arcsine square root of each datum before the analysis. For soil EEAs measured at year-two, we compared saltwater 
treatment to control within each site using a Welch's two-sample t-test $(\alpha=0.05)$. All analyses were performed in RStudio (R Core Team 2017 version 3.3.3).

\section{Path analysis}

We constructed a path model with hypothesized links based on previous studies of how stoichiometry, salinity, and enzyme activities affect litter breakdown rates (e.g., Servais et al. in review, Figure 1). We used eleven predictor variables for root litter $k$ when it was significantly affected by our saltwater treatment: phosphatase, arylsulfatase, $\beta$-1,4-glucosidase, and $\beta$-1,4-cellobiosidase enzyme activities, salinity, litter C:N, litter $\mathrm{C}: \mathrm{P}$, porewater DOC, porewater TN and TDN, porewater SRP and porewater $\mathrm{SO}_{4}{ }^{-}$. We removed links from the model to improve model parsimony in cases where maintaining a specific link had a negligible impact on the overall model fit based on nonsignificant parameter estimates. We evaluated the support for each model based on Akaike's Information Criterion (AIC; Anderson and Burnham 2002).

\section{RESULTS}

\section{Porewater physicochemistry}

At the freshwater site, we were able to increase porewater salinity concentrations an average of $9 \times$ in our treatment chambers $24 \mathrm{~h}$ after dosing $(P<0.01$, Table 1.). Salinity additions increased $\mathrm{pH}(P<0.01)$ but had no effect on alkalinity $(P=0.31$, Table 1.). Dissolved organic $\mathrm{C}$, temperature, and soil redox were not different between saltwater treatment and control chambers (all $P>0.05$, Table 1.). Total dissolved $\mathrm{N}$ and $\mathrm{NH}_{4}{ }^{+}$were $1.5 \times$ and $2.2 \times$ higher in the saltwater treatment chambers compared to the 
controls $24 \mathrm{~h}$ after each dosing event (both $P<0.01$, Table 1). Both SRP and TDP were not different between control and saltwater treatment chambers $24 \mathrm{~h}$ after dosing (both $P$ $>0.05,1)$. Sulfate was $138 \times$ higher in the saltwater treatment chambers compared to the control chambers $24 \mathrm{~h}$ after dosing $(P<0.01$, Table 1$)$. Sulfide was also significantly higher in the treatment chambers compared to the controls $(P<0.01$, Table 1$)$.

At the brackish site, we increased porewater salinity an average of $1.5 \times$ in our treatment chambers $24 \mathrm{~h}$ after dosing events $(P<0.01,1)$. Porewater temperatures were not different between control and treatment wetland chambers $(P=0.64$, Table 1$)$. Saltwater additions lowered porewater $\mathrm{pH}$ and alkalinity (both $P<0.01$, Table 1). After $24 \mathrm{~h}, \mathrm{TDN}, \mathrm{NH}_{4}{ }^{+}, \mathrm{SRP}$, and TDP were all reduced by approximately $50 \%$ with added saltwater (all $P<0.01$, Table 1$)$. Sulfate $\left(\mathrm{SO}_{4}{ }^{-2}\right)$ concentrations were $2.4 \times$ higher with added saltwater within 24 -h after dosing $(P<0.01$, Table 1$)$, whereas sulfide $\left(\mathrm{HS}^{-}\right)$was $2.3 \times$ lower treatment compared to control wetland chambers $(P<0.01$, Table 1$)$. Soil redox was approximately $2 \times$ higher in the saltwater treatments compared to the control $(P$ $<0.01$, Table 1).

\section{Root litter breakdown rates}

At the brackish site, short-term (30-d) $k$ was $1.25 \times$ higher in the saltwater treatment compared to the controls (Table 2; $P<0.05)$, However, long-term (740-d) $k$ were not different between controls and saltwater treatment chambers $(P>0.05$; Table 2). At the freshwater site, neither short-term nor long-term $k$ were different between the control and saltwater treatment chambers for both E. cellulosa and C. jamaicense $(P>$ 0.05; Table 2). 
We also quantified variation in percent AFDM remaining for root litter during the 2-year incubation. At the freshwater site, treatment and days of incubation interacted and affected percent AFDM remaining within the $0-10 \mathrm{~cm}$ depth, where treatment chambers show higher percent AFDM remaining on the third collection (Table 3). There was no effect of the treatment, date, or species on the percent AFDM remaining in the $10-20 \mathrm{~cm}$ depth (all $P>0.05$; Table 3). There was a significant effect of species and an interaction between date and species on the percent of AFDM remaining in the $20-30 \mathrm{~cm}$ depth, on the final collection the percent of AFDM remaining was higher for $C$. jamaicense (Table 3, Figure 3). E. cellulosa root litter from the first collection (30-d/December 2014) had approximately $73 \%$ AFDM remaining and had 68\% AFDM remaining on the last collection (740-d/November 2016) across all depths and treatments. $C$. jamaicense root litter from the first collection (30-d/December 2014) had approximately 72\% AFDM remaining and had 71\% AFDM remaining on the last collection (740-d/November 2016) across all depths and treatments.

At the brackish site, percent root litter mass remaining decreased over time at all depths (Table 4, Figure 4 a,b,c). Root litter from the first collection (30-d/December 2014) had approximately 73\% AFDM remaining and had 64\% AFDM remaining on the last collection (740-d/November 2016) across all depths and treatments. The saltwater treatment alone did not affect percent AFDM remaining. However, there was an interaction between date and saltwater treatment that resulted in significant differences in percent AFDM remaining on the June $20^{\text {th }}, 2016$ collection within the $0-10 \mathrm{~cm}$ depth. 


\section{Root litter elemental content and stoichiometry}

At the freshwater site, the majority of changes in litter stoichiometry were attributed to litter species and sampling date, whereas saltwater treatment did not affect (Table 3). Within the $0-10 \mathrm{~cm}$ depth, the sampling date affected root litter $\% \mathrm{C}, \% \mathrm{~N}$, and $\% \mathrm{P}$ (Table 3, Figure $3 \mathrm{~d}, \mathrm{~g}, \mathrm{j}$ ). E. cellulosa tended to have lower \%C than C. jamaicense within the $0-10 \mathrm{~cm}$ depth (Table 3). Within the $10-20 \mathrm{~cm}$ depth, root litter $\% \mathrm{C}, \% \mathrm{~N}$, and $\% \mathrm{P}$ were all affected by sampling date (Table 3, Figure $3 \mathrm{e}, \mathrm{h}, \mathrm{k}$ ). Within the $20-30 \mathrm{~cm}$ depth, there was an interaction between date and species for the $\% \mathrm{P}$, an effect of date alone on $\% \mathrm{C}, \% \mathrm{~N}, \% \mathrm{P}$ (Table 3, Figure $3 \mathrm{f}, \mathrm{i}, 1)$. Within the $20-30 \mathrm{~cm}$ depth, E. cellulosa tended to have lower \%P than C. jamaicense in the December 2014, February 2015, and May 2015 collections but the differences in \% P appear to attenuate over time. Root litter $\% \mathrm{C}$ for both species were similar throughout breakdown and remained above $45 \%$ during the first six months of breakdown and dropped below $45 \%$ after that (Figure 3 ). The $\% \mathrm{~N}$ and \%P were both lower in the December 2014, February 2015, and May 2015 collections and tended to be higher in the June and November 2016 collections for all depths (Figure 3). At the freshwater site, changes in root litter C:N, C:P, and N:P were affected by date and species. Overall, $\mathrm{C}: \mathrm{N}$ and $\mathrm{C}: \mathrm{P}$ tended to be highest at the second collection before dropping lower after a year of incubation, while $\mathrm{N}: \mathrm{P}$ generally decreased across sampling dates.

At the brackish site, the majority of changes in litter stoichiometry were attributed to sampling date. At $0-10 \mathrm{~cm}$ depth, root litter $\% \mathrm{C}$ was unaffected by pulsed saltwater or days of incubation (Figure $4 \mathrm{~d}$ ). The $\% \mathrm{~N}$ was typically higher in the saltwater treatment root liter and increased over time for both treatments and controls during the incubation 
period (Figure $4 \mathrm{~g}$ ). The $\% \mathrm{P}$ increased over time during the incubation period but was not affected by pulsed saltwater (Figure $4 \mathrm{j}$; Table 4). At 10-20 cm depth, root litter \%C decreased between the first and fifth collection and increased slightly between the June and November 2016 collections (Figure 4 e). At 10-20 cm depth, $\% \mathrm{~N}$ and $\% \mathrm{P}$ increased over time (Figure $4 \mathrm{~h}, \mathrm{k}$ ). At 20-30 $\mathrm{cm}$ depth, there was a significant effect of time on $\% \mathrm{C}$ which decreased over time with the lowest \%C measured during the June 2016 collection (Table 4; Figure $4 \mathrm{f}$ ). The $\% \mathrm{~N}$ increased over time with the highest $\% \mathrm{~N}$ estimated during the June 2016 collection (Table 4 Figure 4 i). The \%P which was low during the first three collections and higher during the final three collections (Table 4; Figure 4 1). At the brackish site, changes in root litter C:N, C:P, and N:P were only affected by date for all three depths and tended to decrease during the two-year experiment (Table 4).

\section{Extracellular enzyme potential}

At the freshwater site, there were no direct effects of pulsed saltwater on EEAs measured on root litter material. Phosphatase was low across sampling dates except for the June 2016 collection when it was highest. Phosphatase was significantly different between species within the $0-10$ and $20-30 \mathrm{~cm}$ depths with E. cellulosa generally having higher phosphatase activities, there was also an interaction between species and sampling collection within the 0-10 cm depth where E. cellulosa had higher activities on the June 2016 collection (Table 5; Figure 5 a, b, c). There was no effect of the saltwater treatment, sampling date, nor species on arylsulfatase activity within the 0-10 $\mathrm{cm}$ depth (Figure $5 \mathrm{~d}$ ). However, at the 10-20 cm depth, there was a significant difference between the litter species, an interaction between sampling date and treatment, and an interaction between 
species, date, and treatment within the $10-20 \mathrm{~cm}$ depth (Figure 5 e). There was only an effect of sampling date on arylsulfatase within the $20-30 \mathrm{~cm}$ depth (Figure $5 \mathrm{f}$ ). $\beta-1,4-$ glucosidase activity varied across sampling dates within all soil depths but was unaffected by saltwater treatment or the species of the litter (Figure $5 \mathrm{~g}, \mathrm{~h}, \mathrm{i}$ ). $\beta-1,4-$ cellobiosidase varied across sampling date within the 0-10 and 20-30 cm depth, and there was an interaction between date and species within the 20-30 $\mathrm{cm}$ depth (Figure $5 \mathrm{j}, \mathrm{k}, 1$ ). However, within the 10-20 cm depth, there was no effect of treatment, date, or species on $\beta$-1,4-cellobiosidase activity. Leucine aminopeptidase activity was low and often undetectable at the freshwater site. Within the $0-10 \mathrm{~cm}$ depth, leucine aminopeptidase was affected by species generally had higher activities, sampling date, an interaction between treatment and date. The highest leucine aminopeptidase activities were measured on E. cellulosa and were highest for both species during the June 2016 collection (Figure $5 \mathrm{~m}$ ). Leucine aminopeptidase was only different across sampling dates in the $10-20 \mathrm{~cm}$ depth with the June 2016 collection having the highest measured activities and unaffected by treatment, date, and species in the 20-30 depth (Figure $5 \mathrm{n}$, o; Table 5).

At the brackish site, there were no direct effects of pulsed saltwater on EEAs measured on root litter material. Phosphatase activity varied across sampling collections within all depths and generally increased over time with highest activities occurring in June 2016 before dropping slightly on the final collection in November 2016 (Figure 6 a, b). Arylsulfatase activity also varied with sampling date for all depths, and there was an interaction between sampling date. There was also an interaction between date and the saltwater treatment for arylsulfatase within the $10-20 \mathrm{~cm}$ depth where on the final sampling collection (Figure 6 h, 11/20/2016) there was a significant difference between 
the treatments and controls $(P<0.01$; Table 6$)$. The $\beta$-1,4-glucosidase activity also varied across sampling collections within all depths, and highest activities were measured during the June and November 2016 collections. There were also significant interactions between treatment and sampling date, within the 10-20 and 20-30 cm depth. $\beta-1,4-$ glucosidase activity in November 2016 was $2.0 \times$ and $3.25 \times$ higher on the root litter from saltwater treatment chambers compared to controls, respectively $(P=0.01$; Table 6 ;

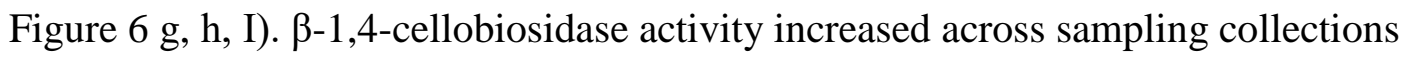
within all depths with highest activities measured in the $0-10 \mathrm{~cm}$ depth on the November 2015 collection (Figure 6 j, k, 1). Leucine aminopeptidase activity was low and often undetectable and only varied across sampling collections within the $0-10 \mathrm{~cm}$ depth where highest activities were measured during the June 2016 collection (Figure 6 m, n, o; Table $6)$.

\section{Bulk soil properties}

At the freshwater site, there were no differences in bulk soil enzyme activities between treatment and control chambers, except for arylsulfatase activities in the 10-20 cm depth $(P=0.04$; Table 7$)$. There were no differences in soil enzyme activities between controls and saltwater treatments at the brackish site (Table 8). Overall, soil enzyme activities were highest in the $0-10 \mathrm{~cm}$ depth at both sites (Table 7; Table 8). Soil $\% \mathrm{C}$ at $0-10 \mathrm{~cm}$ depth at the freshwater site was $1.15 \times$ lower in the treatment chambers $(P$ $<0.01$; Table 9). However, there were no differences in $\% \mathrm{C}$ at $10-20 \mathrm{~cm}$ or $20-30 \mathrm{~cm}$ depths (Table 9). Soil \% $\mathrm{N}$ at the freshwater site was not different between treatments and controls at any depth (Table 9). Soil \%P was higher within the treatment chambers, but 
only in the $10-20 \mathrm{~cm}$ depth $(P=0.02$; Table 9$)$. At the brackish site, both soil $\% \mathrm{C}$ and $\% \mathrm{P}$ was the same between controls and treatments for all depths (Table 9). Soil \% $\mathrm{N}$ was only different in the $10-20 \mathrm{~cm}$ depth and was lower in the treatment chambers $(P=0.02$; Table 9). Microbial biomass $C$ was not different between control and saltwater treatment chambers at either site (all $P>0.05$; Tables 7 and 8 ).

\section{Path analysis}

We conducted a path analysis to test if $C$. jaimaicense root litter $k$ was significantly different between saltwater treatment and control. To increase the number of replicates in our path analysis, we used $k, \mathrm{C}: \mathrm{N}, \mathrm{C}: \mathrm{P}$ and EEAs from each depth as individual replicates. We applied the path analysis approach for $k$ only on brackish site short-term data where $k$ was 1.25 higher in saltwater treatment chambers compared to control chambers (Table 2). For the brackish site, short-term $k$ the best-supported model predicted $44 \%$ of the variation in root litter $k$. Both C:P $(-0.59)$ and C:N $(-0.26)$ were directly and negatively correlated with $k$ (Figure 7). $\beta$-1,4-cellobiosidase (1.29), phosphatases (-1.10), and arylsulfatase (-0.40) enzyme potential were significantly correlated with C:N. DOC (-0.84) and TDN (0.63) were correlated with arylsulfatase enzyme potential (Figure 7). Salinity was negatively correlated with DOC (-0.81) and TDN (-0.72; Figure 7).

\section{DISCUSSION}

The breakdown rate of organic matter regulates nutrient cycling and determines if ecosystems accumulate $\mathrm{C}$ or not. The slow decay of plant detritus promotes the 
accumulation of peat soil rich in organic matter (Mitsch and Gosselink 2007). Changing environmental conditions, like SWI, may alter rates of microbially-mediated organic matter processing. We tested how both short- and long-term exposure to pulses of salinity affect microbial activities and root litter breakdown. We found that pulsed additions of saltwater affect porewater biogeochemistry and enhance short-term breakdown of organic matter in the brackish soil. However, repeated pulsed additions of saltwater did not have long-term effects on microbially-mediated processing of organic matter in freshwater and brackish soils. Effects of saltwater pulsing varied between short-and long-term responses and between freshwater and brackish locations. When breakdown rates were affected by saltwater dosing, it was mediated by P-, S-, and C-acquiring enzymes that led to stoichiometric changes within decomposing root litter (Figure 7). Here we provide evidence that suggests the breakdown of plant detritus is not the primary mechanism behind soil subsidence within the Everglades following SWI.

Saltwater pulses had an immediate effect on porewater biogeochemistry that varied between sites. At the freshwater site, we increased salinity $9 \times$ higher than ambient conditions. Saltwater additions resulted in increased porewater sulfur $\left(\mathrm{SO}_{4}{ }^{2-}\right.$ and $\left.\mathrm{HS}^{-}\right)$ likely because the saltwater solution used for dosing had higher concentrations of sulfate which also increased sulfate reduction and the production of sulfide (Atkinson and Bingham 1997). Saltwater additions also increased porewater $N$ concentrations (TDN and $\mathrm{NH}_{4}^{+}$) at the freshwater site. We attribute $\mathrm{N}$ increases to the release of adsorbed $\mathrm{N}$ compounds from the soil into the porewater (Weston et al. 2006). Previous research confirms that SWI increases the concentrations of marine-derived dissolved ions causing the desorption of nutrient ions from exchange sites (Rosenfeld 1979, Liu and Lee 2007, 
Ardón et al. 2013). Therefore, SWI can increase the availability of desorbed nutrients to plants, soil microbes, and the likelihood of transport of these constituents downstream. At the brackish site, saltwater dosing had the opposite effect and decreased dissolved porewater constituents (DOC, TDN, $\mathrm{NH}_{4}{ }^{+}, \mathrm{SRP}, \mathrm{TDP}$, and $\mathrm{HS}^{-}$). Brackish marshes, previously exposed to seawater, may have already exported desorbed nutrients from SWI and when exposed to pulses of saltwater dosing experience a dilution of porewater $\mathrm{C}$ and nutrients, as we saw in our experiment (Table 1). Overall, our initial hypothesis that SWI would increase dissolved $\mathrm{C}$ and nutrient in the porewater was only partially supported. Within the freshwater site, SWI increased porewater $\mathrm{N}$ and $\mathrm{S}$, but not $\mathrm{C}$, whereas within the brackish site SWI decreased dissolved nutrients and C. Saltwater dosing alters porewater biogeochemistry; however, the effect is site-specific and may depend on legacies of previous SWI.

We anticipate that a disruption in the balance of $\mathrm{C}$ inputs and outputs is an early indicator of peat collapse following SWI. However, we only detected changes in bulk soil organic $\mathrm{C}$ at the freshwater site where soil organic $\mathrm{C}$ was $1.15 \times$ lower within the saltwater treatment chambers after two years. Results from previous studies are mixed and have reported both increases and decreases in soil $\mathrm{C}$ with saltwater additions (Weston et al. 2006, Weston et al. 2011, Neubauer et al. 2013). Adding to the heterogeneity in soil $\mathrm{C}$ responses to SWI found in the literature, we did not observe changes in soil organic $\mathrm{C}$ at the brackish site. We think the loss of soil C with increases in SWI in long-hydroperiod wetlands, where organic matter breakdown is slow, can be attributed to decreased C inputs from plants into the soil as opposed to increased microbial mineralization (Wilson 
et al. in prep). Environmental conditions at each site and legacies of salt exposure may influence how SWI affects soil organic C.

Despite the significant changes to soil and porewater biogeochemistry, pulses of saltwater did not affect long-term changes in the proportion of root litter remaining at both freshwater and brackish sites. The greatest changes in the proportion of root litter mass remaining occurred within the first $30-\mathrm{d}$. Root litter lost was approximately $30 \%$ at both sites within the first 30 days of incubation and only lost an additional 5-10\% by the end of the 740-d incubation period. Previous breakdown studies within the Everglades report similar patterns of litter decay, for example, leaching accounts for about $33 \%$ of mass losses in Rhizophora mangle in the first three weeks of incubation (Newman et al. 2001, Davis et al. 2003). Another study by Pisani et al. (2017) found even slower rates of breakdown for both $C$. jamaicense and E. cellulose. While we did not detect long-term effects of saltwater pulses breakdown studies from other wetlands have shown mixed effects with some studies showing saltwater to increase decomposition (Mendelssohn et al. 1999, Craft 2007) while others studies show saltwater to decrease decomposition (Mendelssohn et al. 1999). In our experiment, saltwater dosing only affected short-term breakdown at the brackish site where $k$ increased $1.25 \times$ in the saltwater treatment chambers.

Using path analysis, we were able to characterize $44 \%$ of the variation in shortterm litter breakdown at the brackish site. We detected changes in $k$ at the brackish site and linked it to changes in C:N and C:P content (Figure 7). Exposure to initial pulses of elevated saltwater resulted in a $1.25 \times$ increase in short-term root litter $k$ at the brackish site. Both C:N and C:P were negatively correlated with root litter $k$, a result also found on 
decaying leaves in streams (Manning et al. 2015). The inverse relationship between C:N and $\mathrm{C}: \mathrm{P}$ and litter breakdown indicate that $\mathrm{C}$ is lost from the litter and $\mathrm{N}$ and $\mathrm{P}$ content increase on litter as it is colonized (Zechmeister-Boltenstern et al. 2015). Short-term breakdown rates at the brackish site were indirectly affected by changes in $\mathrm{P}-, \mathrm{S}-$, and Cacquiring enzyme activity that altered elemental stoichiometry which had direct effects on litter breakdown rates. Salinity was important in determining S-acquiring enzyme activities by changing concentrations of DOC and TDN within the porewater. Increases in salinity led to decreased DOC and TDN within the porewater, higher concentrations of DOC resulted in decreased S-acquiring enzymes as accessible $\mathrm{C}$, dissolved in the porewater decreases microbial demand for elemental sulfur. Our best fitting model for the path analysis was only able to predict $44 \%$ of the variation in $k$, indicating that we were unable to capture all the factors contributing to increased breakdown rate with saltwater pulses. For example, we anticipate that exposure to saltwater increases leaching of soluble materials during the initial stages of litter breakdown and may help explain why there is only a short-term effect of saltwater addition in our study. Three primary processes are often described contributing to the breakdown of organic matter: (1) leaching of soluble compounds, (2) microbial oxidation of recalcitrant components, (3) physical and biological fragmentation (Valiela et al. 1985). Typically, the leaching of soluble compounds dominants changes in the mass loss early on and microbiallymediated breakdown occurs at longer timescales.

Anaerobic conditions in water-logged soils serve as a latch on microbial decomposition (Freeman et al. 2001, Tokarz and Urban et al. 2015), as oxygen concentrations determine many biogeochemical cycles (Helton et al. 2015). Reduced soil conditions and inundation 
limit microbially-mediated decay (McKee and Seneca 1982, White and Trapani 1982). We believe that within our study sites, inundation of the soil dictated microbial activities and limited responses of microbial EEAs and long-term breakdown rates to saltwater addition. For instance, soil inundation and waterlogging result in changes in microbial community composition, the production of new enzymes, and leads to increased concentration of enzyme inhibitors (Pulford and Tabatabai 1988, Freeman et al. 1996). At our freshwater site, a long-hydroperiod marsh, the water level fell below the soil surface for only 39 days during the entire two-year study. At our brackish site, with a slightly shorter hydroperiod, water dropped below the soil surface for only 132 days. Interestingly, pulses of saltwater increased brackish soil redox potential $200 \%$, though soils remained slightly reduced and there was little change in enzyme activities compared to the controls (Husson 2013). Additionally, the higher activities in the shallow sampling depths of soil and roots compared to lower activities within the deeper sampling depths provide further evidence that oxygen-limited conditions may suppress microbial activity and promote slow breakdown rates despite changes in salinity. However, when the water table falls, increased oxygen availability and the removal of inhibitory metal ions could activate the enzyme activities in the Everglades and leave soils exposed to a new latch on the microbial processing of organic matter (Freeman et al. 1996). More work is necessary to understand how increases in saltwater may interact with drought to affect microbiallymediated processing of organic matter.

Although the majority of changes in EEAs were attributed to temporal variation, we detected increases [two-fold $(10-20 \mathrm{~cm})$, three-fold increases $(20-30 \mathrm{~cm})]$ in $\beta-1,4-$ glucosidase activity with associated with root litter after two-years in saltwater treatment 
plots at the brackish site. Previous studies have suggested that increases in $\beta-1,4-$ glucosidase activity are explained by increases in cellobiose (Chröst 1991). $\beta-1,4-$ glucosidase is a mediator of cellulose degradation and can be considered the rate-limiting step in the degradation of cellulose (Sinsabaugh et al. 1993, Alef and Nannipieri 1995). Previous studies that exposed soils to saltwater also measured decreased glucosidase activities (Jackson and Vallaire 2009, Neubauer et al. 2013). However, the higher activities of $\beta$-1,4-glucosidase activity with saltwater on treated root litter was not detected in the bulk soil and did not result in changes in root breakdown rates. It is important to investigate further how repeated exposure to saltwater pulses might alter EEAs as even minor changes in enzyme activity can result in ecosystem-level changes. Our results indicate that coastal soil microbial communities in reduced soil ecosystems have low sensitivity to pulsed SWI and are unlikely the primary mechanism of C loss, compared to microbial communities continuously exposed to saltwater (Servais et al. in review). Changes in microbially-mediated breakdown may only occur with continued saltwater exposure, more extreme levels of salinity, or when other latches on microbial processing, like inundation, are also altered. For example, Freeman et al. (1996) found that P-, S-, and C-acquiring enzymes activities were increased up to $70 \%$ within peat soils after water table drawdown. Therefore, we expect drier wetland conditions to increase organic mineralization resulting from higher enzyme activities (Freeman et al. 1996) and have greater sensitivity to SWI.

Peat soils are prevalent within much of the coastal Everglades (Craft and Richardson 2008) and are susceptible to collapse (Day et al. 2011) which has been predicted to result from dry down, accelerated decomposition, or root death (Chambers et al. 2015). Peat 
collapse has already begun within the Everglades (Wanless and Vlaswinkel 2005) and has been documented at our brackish site and attributed to increases in $\mathrm{C}$ fluxes out of the system resulting from combinations of elevated salinity and drought (Wanless and Vlaswinkel 2005, Wilson et al. in prep). We hypothesize that inundation is acting as a "latch" on microbially-mediated organic matter processing and may explain the lack of responses in long-term litter $k$ and EEAs to SWI in our study. More work is necessary to determine what environmental conditions interact with SWI (e.g., drought, temperature) to exacerbate microbially-mediated decomposition. Our results suggest that increased breakdown of plant detritus is not the primary mechanism behind rapid soil subsidence within the Everglades.

\section{ACKNOWLEDGMENTS}

We thank R. Stolee, G. Cabral, K. Morales, and D. Segrera for field and laboratory assistance. We thank the Everglades Section of the South Florida Water Management District and Everglades National Park for providing facilities support during this research. Funding for this research was provided by the National Science Foundation award (DEB-1237517) to the Florida Coastal Everglades Long Term Ecological Research (FCE LTER) Program. S. Servais was supported by research assistantships from Florida Sea Grant (R/C-S-56) and FCE LTER, teaching assistantship for Florida International University, and Florida International University's Dissertation Year Fellowship. This manuscript is contribution number XX from the Southeast Environmental Research Center in the Institute of Water and Environment at Florida International University. 


\section{REFERENCES}

Alef, K. and Nannipieri, P., 1995. Methods in applied soil microbiology and biochemistry (No. 631.46 M592ma). Academic Press,

Allison, S.D. and Vitousek, P.M., 2004. Extracellular enzyme activities and carbon chemistry as drivers of tropical plant litter decomposition. Biotropica, pp.285-296.

Anderson, D.R. and Burnham, K.P., 2002. Avoiding pitfalls when using informationtheoretic methods. The Journal of Wildlife Management, pp.912-918.

Ardón, M., Morse, J.L., Colman, B.P. and Bernhardt, E.S., 2013. Drought-induced saltwater incursion leads to increased wetland nitrogen export. Global Change Biology, 19(10), pp.2976-2985.

Atkinson, M.J. and Bingman, C., 1997. Elemental composition of commercial seasalts. Journal of Aquariculture and Aquatic Sciences, 8(2), pp.39-43.

Brinson, M.M., 1977. Decomposition and nutrient exchange of litter in an alluvial swamp forest. Ecology, 58(3), pp.601-609.

Burns, R.G., 1982. Enzyme activity in soil: location and a possible role in microbial ecology. Soil Biology and Biochemistry, 14(5), pp.423-427.

Craft, C., 2007. Freshwater input structures soil properties, vertical accretion, and nutrient accumulation of Georgia and US tidal marshes. Limnology and Oceanography, 52(3), pp.1220-1230.

Chambers, L.G., Reddy, K.R. and Osborne, T.Z., 2011. Short-term response of carbon cycling to salinity pulses in a freshwater wetland. Soil Science Society of America Journal, 75(5), pp.2000-2007.

Chambers, L.G., Davis, S.E., Troxler, T.G. and Entry, J.A., 2015. Sea level rise in the Everglades: plant-soil-microbial feedbacks in response to changing physical conditions. Microbiology of the Everglades Ecosystem, pp.89-112.

Chambers, L.G., Guevara, R., Boyer, J.N., Troxler, T.G. and Davis, S.E., 2016. Effects of salinity and inundation on microbial community structure and function in a mangrove peat soil. Wetlands, 36(2), pp.361-371.

Chröst, R.J., 1991. Environmental control of the synthesis and activity of aquatic microbial ectoenzymes. In Microbial enzymes in aquatic environments (pp. 29-59). Springer, New York, NY.

Day, J.W., Kemp, G.P., Reed, D.J., Cahoon, D.R., Boumans, R.M., Suhayda, J.M. and Gambrell, R., 2011. Vegetation death and rapid loss of surface elevation in two contrasting Mississippi delta salt marshes: The role of sedimentation, autocompaction and sea-level rise. Ecological Engineering, 37(2), pp.229-240.

Davis III, S.E., Coronado-Molina, C., Childers, D.L. and Day Jr, J.W., 2003. Temporally dependent C, N, and P dynamics associated with the decay of Rhizophora mangle L. 
leaf litter in oligotrophic mangrove wetlands of the Southern Everglades. Aquatic Botany, 75(3), pp.199-215.

Dessu, S.B., Price, R.M., Troxler, T.G. and Kominoski, J.S., 2018. Effects of sea-level rise and freshwater management on long-term water levels and water quality in the Florida Coastal Everglades. Journal of Environmental Management, 211, pp.164-176.

Dick, R.P., 1994. Soil Enzyme Activities as Indicators of Soil Quality1. Defining soil quality for a sustainable environment, pp.107-124.

Freeman, C., Liska, G., Ostle, N.J., Lock, M.A., Reynolds, B. and Hudson, J., 1996. Microbial activity and enzymic decomposition processes following peatland water table drawdown. Plant and Soil, 180(1), pp.121-127.

Freeman, C., Ostle, N. and Kang, H., 2001. An enzymic 'latch' on a global carbon store. Nature, 409(6817), p.149.

Helton, A.M., Ardón, M. and Bernhardt, E.S., 2015. Thermodynamic constraints on the utility of ecological stoichiometry for explaining global biogeochemical patterns. Ecology Letters, 18(10), pp.1049-1056.

Hoorens, B., Aerts, R. and Stroetenga, M., 2003. Does initial litter chemistry explain litter mixture effects on decomposition? Oecologica, 137(4), pp.578-586.

Husson, O., 2013. Redox potential (Eh) and pH as drivers of soil/plant/microorganism systems: a transdisciplinary overview pointing to integrative opportunities for agronomy. Plant and Soil, 362(1-2), pp.389-417.

Jackson, C.R., Foreman, C.M. and Sinsabaugh, R.L., 1995. Microbial enzyme activities as indicators of organic matter processing rates in a Lake Erie coastal wetland. Freshwater Biology, 34(2), pp.329-342.

Jackson, C.R. and Vallaire, S.C., 2009. Effects of salinity and nutrients on microbial assemblages in Louisiana wetland sediments. Wetlands, 29(1), pp.277-287.

Kang, H. and Freeman, C., 1999. Phosphatase and arylsulphatase activities in wetland soils: annual variation and controlling factors. Soil Biology and Biochemistry, 31(3), pp.449-454.

Liu, Z. and Lee, C., 2007. The role of organic matter in the sorption capacity of marine sediments. Marine Chemistry, 105(3), pp.240-257.

Manning, D.W., Rosemond, A.D., Kominoski, J.S., Gulis, V., Benstead, J.P. and Maerz, J.C., 2015. Detrital stoichiometry as a critical nexus for the effects of streamwater nutrients on leaf litter breakdown rates. Ecology, 96(8), pp.2214-2224.

McKee, K.L. and Seneca, E.D., 1982. The influence of morphology in determining the decomposition of two salt marsh macrophytes. Estuaries, 5(4), pp.302-309. 
Mendelssohn, I.A., Sorrell, B.K., Brix, H., Schierup, H.H., Lorenzen, B. and Maltby, E., 1999. Controls on soil cellulose decomposition along a salinity gradient in a Phragmites australis wetland in Denmark. Aquatic Botany, 64(3-4), pp.381-398.

Mitsch, W.J. and Gosselink, J.G., 2007. Wetlands, 4th edition

Morrissey, E.M., Gillespie, J.L., Morina, J.C. and Franklin, R.B., 2014. Salinity affects microbial activity and soil organic matter content in tidal wetlands. Global Change Biology, 20(4), pp.1351-1362.

Newman, S., Kumpf, H., Laing, J.A. and Kennedy, W.C., 2001. Decomposition responses to phosphorus enrichment in an Everglades (USA) slough. Biogeochemistry, 54(3), pp.229-250.

Neubauer, S.C., Franklin, R.B. and Berrier, D.J., 2013. Saltwater intrusion into tidal freshwater marshes alters the biogeochemical processing of organic carbon. Biogeosciences, 10(12), p.8171.

Nyman, J.A., Walters, R.J., Delaune, R.D. and Patrick Jr, W.H., 2006. Marsh vertical accretion via vegetative growth. Estuarine, Coastal and Shelf Science, 69(3-4), pp.370-380.

Pearlstine, L.G., Pearlstine, E.V. and Aumen, N.G., 2010. A review of the ecological consequences and management implications of climate change for the Everglades. Journal of the North American Benthological Society, 29(4), pp.1510-1526.

Odum, W.E., Odum, E.P. and Odum, H.T., 1995. Nature's pulsing paradigm. Estuaries, $18(4)$, p.547.

Olson, J.S., 1963. Energy storage and the balance of producers and decomposers in ecological systems. Ecology, 44(2), pp.322-331.

Pisani, O., Gao, M., Maie, N., Miyoshi, T., Childers, D.L. and Jaffé, R., 2018. Compositional aspects of herbaceous litter decomposition in the freshwater marshes of the Florida Everglades. Plant and Soil, 423(1-2), pp.87-98.

Pulford, I.D. and Tabatabai, M.A., 1988. Effect of waterlogging on enzyme activities in soils. Soil Biology and Biochemistry, 20(2), pp.215-219.

Rejmánková, E. and Sirová, D., 2007. Wetland macrophyte decomposition under different nutrient conditions: relationships between decomposition rate, enzyme activities and microbial biomass. Soil Biology and Biochemistry, 39(2), pp.526-538.

Rosenfeld, J.K., 1979. Ammonium adsorption in nearshore anoxic sediments. Limnology and Oceanography, 24(2), pp.356-364.

Ross, M.S., Meeder, J.F., Sah, J.P., Ruiz, P.L. and Telesnicki, G.J., 2000. The southeast saline Everglades revisited: 50 years of coastal vegetation change. Journal of Vegetation Science, 11(1), pp.101-112. 
Saiya-Cork, K.R., Sinsabaugh, R.L. and Zak, D.R., 2002. The effects of long term nitrogen deposition on extracellular enzyme activity in an Acer saccharum forest soil. Soil Biology and Biochemistry, 34(9), pp.1309-1315.

Schimel, J.P. and Weintraub, M.N., 2003. The implications of exoenzyme activity on microbial carbon and nitrogen limitation in soil: a theoretical model. Soil Biology and Biochemistry, 35(4), pp.549-563.

Sinsabaugh, R.L. and Linkins, A.E., 1988. Exoenzyme activity associated with lotic epilithon. Freshwater Biology, 20(2), pp.249-261.

Sinsabaugh, R.L., Antibus, R.K. and Linkins, A.E., 1991. An enzymic approach to the analysis of microbial activity during plant litter decomposition. Agriculture, Ecosystems \& Environment, 34(1-4), pp.43-54.

Sinsabaugh, R.L., Antibus, R.K., Linkins, A.E., McClaugherty, C.A., Rayburn, L., Repert, D. and Weiland, T., 1993. Wood decomposition: nitrogen and phosphorus dynamics in relation to extracellular enzyme activity. Ecology, 74(5), pp.1586-1593.

Sinsabaugh, R.L., Carreiro, M.M. and Alvarez, S., 2002. Enzyme and microbial dynamics of litter decomposition. Enzymes in the Environment, Activity, Ecology, and Applications. Marcel Dekker, New York, Basel, pp.249-265.

Sinsabaugh, R.L. and Follstad Shah, J.J., 2012. Ecoenzymatic stoichiometry and ecological theory. Annual Review of Ecology, Evolution, and Systematics, 43, pp.313-343.

Tokarz, E. and Urban, D., 2015. Soil redox potential and its impact on microorganisms and plants of wetlands. Journal of Ecological Engineering, 16(3), pp.20-30.

Valiela, I., Teal, J.M., Allen, S.D., Van Etten, R., Goehringer, D. and Volkmann, S., 1985. Decomposition in salt marsh ecosystems: the phases and major factors affecting disappearance of above-ground organic matter. Journal of Experimental Marine Biology and Ecology, 89(1), pp.29-54.

Vance, E.D., Brookes, P.C. and Jenkinson, D.S., 1987. An extraction method for measuring soil microbial biomass C. Soil Biology and Biochemistry, 19(6), pp.703707.

van der Valk, A.G., Rhymer, J.M. and Murkin, H.R., 1991. Flooding and the decomposition of litter of four emergent plant species in a prairie wetland. Wetlands, 11(1), pp.1-16.

Wanless, H.R. and Vlaswinkel, B., 2005. Coastal landscape and channel evolution affecting critical habitats at Cape Sable, Everglades National Park, Florida. Final Report to Everglades National Park, United States Department of the Interior, Homestead, FL, USA. 
Weston, N.B., Dixon, R.E. and Joye, S.B., 2006. Ramifications of increased salinity in tidal freshwater sediments: Geochemistry and microbial pathways of organic matter mineralization. Journal of Geophysical Research: Biogeosciences, 111(G1).

Weston, N.B., Vile, M.A., Neubauer, S.C. and Velinsky, D.J., 2011. Accelerated microbial organic matter mineralization following salt-water intrusion into tidal freshwater marsh soils. Biogeochemistry, 102(1-3), pp.135-151.

White, D.A. and Trapani, J.M., 1982. Factors influencing disappearances of Spartina alterniflora from litterbags. Ecology, pp.242-245.

White, E. and Kaplan, D., 2017. Restore or retreat? Saltwater intrusion and water management in coastal wetlands. Ecosystem Health and Sustainability, 3(1).

Wright, A.L. and Reddy, K.R., 2001. Phosphorus loading effects on extracellular enzyme activity in Everglades wetland soils. Soil Science Society of America Journal, 65(2), pp.588-595. 
Table 1. Average ( $\pm 1 \mathrm{SE}$ ) of porewater salinity, $\mathrm{pH}$, alkalinity, dissolved organic carbon (DOC), total dissolved nitrogen (TDN), ammonium $\left(\mathrm{NH}_{4}{ }^{+}\right)$, soluble reactive phosphorus (SRP), total dissolved phosphorus (TDP), sulfate $\left(\mathrm{SO}_{4}{ }^{2-}\right)$, sulfide $\left(\mathrm{HS}^{-}\right)$ temperature, and soil redox potential from the brackish and freshwater sites over the two-year duration of the study. Porewater samples were taken at $15-\mathrm{cm}$ depth from the ambient water (control) and saltwater (treatment) addition plots. Salinity is reported in ppt. Alkalinity, DOC, $\mathrm{TDN}, \mathrm{NH}_{4}{ }^{+}$, and $\mathrm{SO}_{4}{ }^{-2}$ are $\mathrm{mg} \mathrm{L}^{-1}$. Soluble

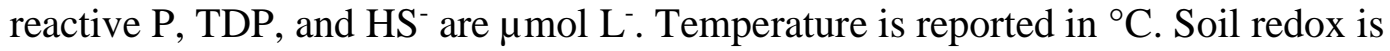
reported in $\mathrm{mV}$. Controls and saltwater treatments were compared for each constituent using a Welch's t-test. Significant differences $(\alpha=0.05)$ are bolded.

\begin{tabular}{|c|c|c|c|}
\hline & control & treatment & significance \\
\hline \multicolumn{4}{|l|}{ freshwater site } \\
\hline salinity & $0.28(0.01)$ & $2.61(0.10)$ & $P<0.01 ; t_{(126.4)}=22.61$ \\
\hline $\mathrm{pH}$ & $7.45(0.03)$ & $7.58(0.03)$ & $P<0.01 ; t_{(225.1)}=2.83$ \\
\hline alkalinity & $174.26(3.15)$ & $179.79(4.37)$ & $P=0.31 ; t_{(205.7)}=1.03$ \\
\hline DOC & $27.79(1.92)$ & $23.59(1.16)$ & $P=0.06 ; t_{(187.0)}=1.87$ \\
\hline TDN & $0.96(0.03)$ & $1.41(0.03)$ & $P<0.01 ; t_{(208.5)}=10.72$ \\
\hline $\mathrm{NH}_{4}{ }^{+}$ & $0.36(0.02)$ & $0.80(0.03)$ & $P<0.01 ; t_{(209.5)}=10.69$ \\
\hline SRP & $0.06(0.00)$ & $0.06(0.01)$ & $P=0.86 ; t_{(239.3)}=0.18$ \\
\hline TDP & $0.30(0.01)$ & $0.32(0.01)$ & $P=0.37 ; t_{(227.0)}=0.90$ \\
\hline $\mathrm{SO}_{4}{ }^{2-}$ & $0.85(0.25)$ & $177.12(7.81)$ & $P<0.01 ; t_{(114.2)}=22.55$ \\
\hline $\mathrm{HS}^{-}$ & $0.00(0.00)$ & $0.05(0.01)$ & $P<0.01 ; t_{(53.6)}=5.26$ \\
\hline temperature & $27.76(0.38)$ & $28.18(0.38)$ & $P=0.44 ; t_{(251.0)}=0.77$ \\
\hline soil redox & $147.68(7.50)$ & $135.06(9.73)$ & $P=0.32 ; t_{(170.19)}=1.00$ \\
\hline \multicolumn{4}{|l|}{ brackish site } \\
\hline salinity & $10.76(0.16)$ & $15.55(0.18)$ & $P<0.01 ; t_{(281.0)}=19.51$ \\
\hline $\mathrm{pH}$ & $7.62(0.02)$ & $7.53(0.02)$ & $P<0.01 ; t_{(269.1)}=3.51$ \\
\hline alkalinity & $537.30(10.76)$ & $305.18(6.03)$ & $P<0.01 ; t_{(213.8)}=18.82$ \\
\hline DOC & $138.99(1.56)$ & $97.37(1.56)$ & $P<0.01 ; t_{(273.0)}=18.90$ \\
\hline TDN & $7.83(0.15)$ & $4.36(0.07)$ & $P<0.01 ; t_{(193.4)}=20.61$ \\
\hline $\mathrm{NH}_{4}{ }^{+}$ & $4.34(0.13)$ & $1.97(0.06)$ & $P<0.01 ; t_{(200.2)}=16.78$ \\
\hline SRP & $4.18(0.18)$ & $1.98(0.10)$ & $P<0.01 ; t_{(220.3)}=11.01$ \\
\hline TDP & $6.66(0.28)$ & $3.03(0.14)$ & $P<0.01 ; t_{(211.5)}=9.71$ \\
\hline $\mathrm{SO}_{4}{ }^{2-}$ & $370.28(13.81)$ & $899.45(20.56)$ & $P<0.01 ; t_{(237.9)}=21.34$ \\
\hline $\mathrm{HS}^{-}$ & $2.820 .13)$ & $1.25(0.07)$ & $P<0.01 ; t_{(155.1)}=9.71$ \\
\hline temperature & $29.030 .33)$ & $29.26(0.34)$ & $P=0.64 ; t_{(286.0)}=0.47$ \\
\hline soil redox & $42.41(11.92)$ & $95.32(10.75)$ & $P<0.01 ; t_{(229.7)}=3.27$ \\
\hline
\end{tabular}


Table 2. Average ( \pm standard deviation) root breakdown rates $\left(k \mathrm{~d}^{-1}\right)$ at 30 and 740 $\mathrm{d}$ for both freshwater and brackish sites. Saltwater treatment $k$ and control $k$ were compared using a Welch two-sample $t$-test at each time point and for both $E$. cellulos $a$ and $C$. jamaicense. Significant differences were determined using $\alpha=$ 0.05

\begin{tabular}{lccc}
\hline & control & treatment & significance \\
\hline freshwater site & & & \\
E. cellulosa & & & \\
30-d & $0.0100(0.0002)$ & $0.0094(0.0005)$ & $P=0.25 ; T=1.19$ \\
740-d & $0.0004(0.0000)$ & $0.0003(0.0001)$ & $P=0.78 ; T=-2.00$ \\
C. jamaicense & & & \\
30-d & $0.0086(0.0003)$ & $0.0121(0.0017)$ & $P=0.40 ; T=0.88$ \\
740-d & $0.0005(0.0002)$ & $0.0002(0.0001)$ & $P=0.19 ; T=1.38$ \\
brackish site & & & \\
C. jamaicense & & & \\
30-d & $0.0096(0.0003)$ & $0.0120(0.0005)$ & $P<0.05 ; T=-3.97$ \\
740-d & $0.0005(0.0000)$ & $0.0005(0.0001)$ & $P=0.43 ; T=-0.79$ \\
\hline
\end{tabular}


Table 3. Full statistical results from a two-way repeated measures ANOVA proportion ash-free dry mass (AFDM) remaining of root litter and percent $(\%)$ carbon $(\mathrm{C})$, nitrogen $(\mathrm{N})$, and phosphorus $(\mathrm{P}), \mathrm{C}: \mathrm{N}, \mathrm{C}: \mathrm{P}$, and $\mathrm{N}: \mathrm{P}$ molar ratios of root litter from the freshwater site $(0-10,10-20,20-30 \mathrm{~cm})$ given treatment, species, and date. Significant $(\alpha=0.05)$ results in bold. Data presented as $\mathrm{F}(\mathrm{numerator}$ degrees of freedom, denominator degrees of freedom $)=\mathrm{F}$ value, $\mathrm{P}=\mathrm{P}$ value.

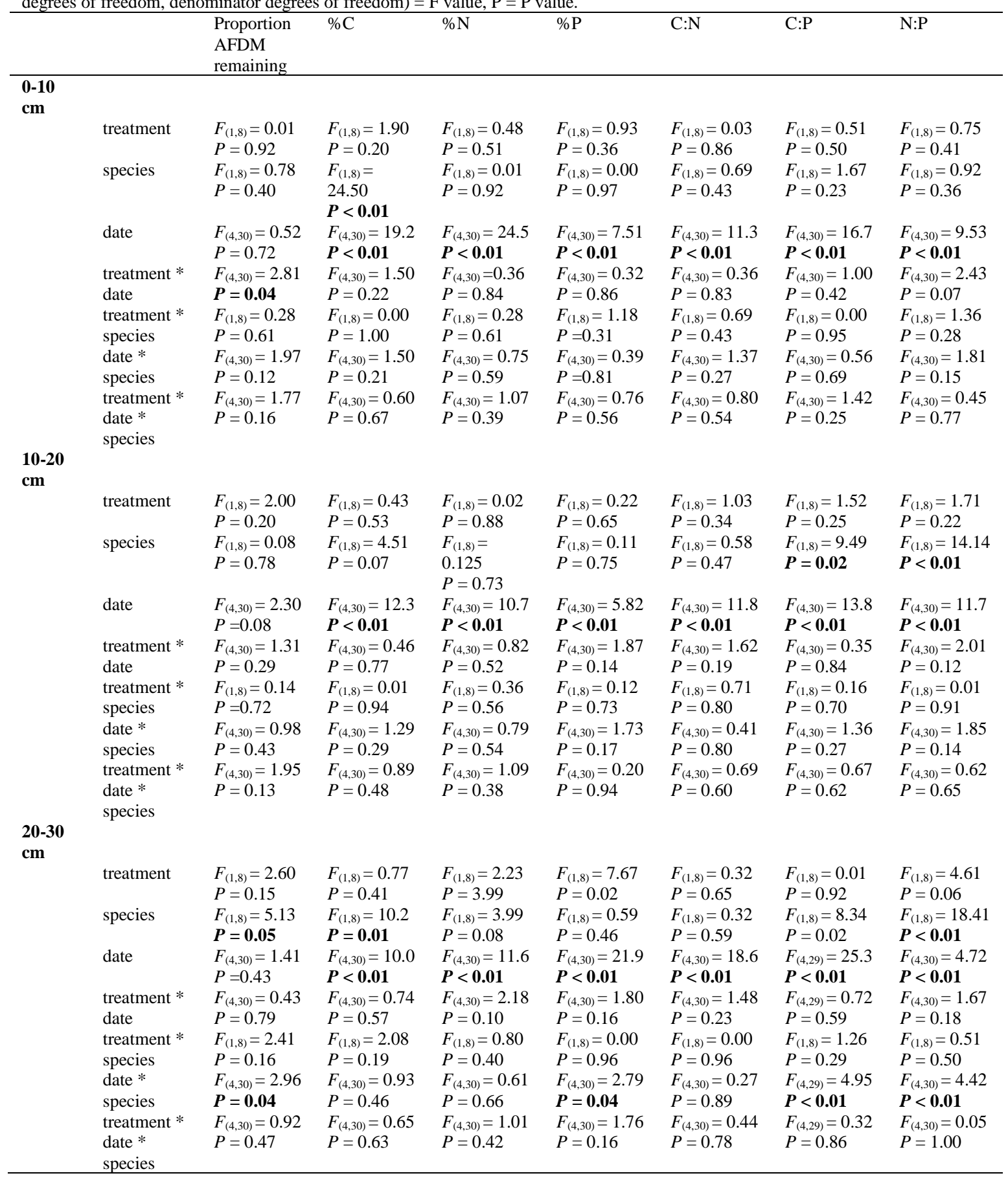


Table 4. Full statistical results from a two-way repeated measures ANOVA for proportion ash-free dry mass (AFDM) remaining of root litter and percent $(\%)$ carbon $(\mathrm{C})$, nitrogen $(\mathrm{N})$, and phosphorus $(\mathrm{P}), \mathrm{C}: \mathrm{N}, \mathrm{C}: \mathrm{P}$, and $\mathrm{N}: \mathrm{P}$ molar ratios of root litter from the brackish site $(0-10,10-20,20-30 \mathrm{~cm})$ given treatment and date. Significant $(\alpha=0.05)$ results in bold. Data presented as $F(n u m e r a t o r$ degrees of freedom, denominator degrees of freedom $)=\mathrm{F}$ value, $\mathrm{P}=\mathrm{P}$ value

\begin{tabular}{|c|c|c|c|c|c|c|c|c|}
\hline & & $\begin{array}{l}\text { Proportion } \\
\text { AFDM } \\
\text { remaining }\end{array}$ & $\% \mathrm{C}$ & $\% \mathrm{~N}$ & $\% \mathrm{P}$ & $\mathrm{C}: \mathrm{N}$ & $\mathrm{C}: \mathrm{P}$ & $\mathrm{N}: \mathrm{P}$ \\
\hline \multicolumn{9}{|l|}{$0-10 \mathrm{~cm}$} \\
\hline & treatment & $F_{(1,10)}=0.392$ & $F_{(1,10)}=0.50$ & $F_{(1,10)}=17.29$ & $F_{(1,10)}=2.29$ & $F_{(1,10)}=1.59$ & $F_{(1,10)}=2.70$ & $F_{(1,10)}=2.90$ \\
\hline & date & $\begin{array}{l}P=0.55 \\
F_{(5,50)}=9.77 \\
P<\mathbf{0 . 0 1}\end{array}$ & $\begin{array}{l}P=0.50 \\
F_{(5,50)}=12.20 \\
P=0.10\end{array}$ & $\begin{array}{l}P=\mathbf{0 . 0 2} \\
F_{(5,50)}=11.43 \\
\boldsymbol{P}<\mathbf{0 . 0 1}\end{array}$ & $\begin{array}{l}P=0.16 \\
F_{(5,50)}=37.59 \\
P<\mathbf{0 . 0 1}\end{array}$ & $\begin{array}{l}P=0.24 \\
F_{(5,50)}=6.19 \\
\boldsymbol{P}<\mathbf{0 . 0 1}\end{array}$ & $\begin{array}{l}P=0.13 \\
F_{(5,50)}=40.26 \\
P<\mathbf{0 . 0 1}\end{array}$ & $\begin{array}{l}P=0.12 \\
F_{(5,50)}=19.91 \\
\boldsymbol{P}<\mathbf{0 . 0 1}\end{array}$ \\
\hline & $\begin{array}{l}\text { treatment } * \\
\text { date }\end{array}$ & $\begin{array}{l}F_{(5,50)}=2.51 \\
P=\mathbf{0 . 0 4}\end{array}$ & $\begin{array}{l}F_{(5,50)}=2.00 \\
P=0.10\end{array}$ & $\begin{array}{l}F_{(5,50)}=1.47 \\
P=0.22\end{array}$ & $\begin{array}{l}F_{(5,50)}=0.37 \\
P=0.86\end{array}$ & $\begin{array}{l}F_{(5,50)}=0.16 \\
P=0.98\end{array}$ & $\begin{array}{l}F_{(5,50)}=0.86 \\
P=0.51\end{array}$ & $\begin{array}{l}F_{(5,50)}=0.52 \\
P=0.76\end{array}$ \\
\hline \multicolumn{9}{|l|}{$\begin{array}{l}10-20 \\
\mathrm{~cm}\end{array}$} \\
\hline & treatment & $\begin{array}{l}F_{(1,10)}=1.14 \\
P=0.31\end{array}$ & $\begin{array}{l}F_{(1,10)}=1.10 \\
P=0.32\end{array}$ & $\begin{array}{l}F_{(1,10)}=6.75 \\
P=0.03\end{array}$ & $\begin{array}{l}F_{(1,10)}=4.95 \\
P=0.05\end{array}$ & $\begin{array}{l}F_{(1,10)}=0.05 \\
P=.83\end{array}$ & $\begin{array}{l}F_{(1,10)}=1.57 \\
P=0.24\end{array}$ & $\begin{array}{l}F_{(1,10)}=0.17 \\
P=0.69\end{array}$ \\
\hline & date & $\begin{array}{l}F_{(5,50)}=10.67 \\
\boldsymbol{P}<\mathbf{0 . 0 1}\end{array}$ & $\begin{array}{l}F_{(5,50)}=13.20 \\
\boldsymbol{P}<\mathbf{0 . 0 1}\end{array}$ & $\begin{array}{l}F_{(5,50)}=13.86 \\
P<\mathbf{0 . 0 1}\end{array}$ & $\begin{array}{l}F_{(5,50)}=54.07 \\
\boldsymbol{P}<\mathbf{0 . 0 1}\end{array}$ & $\begin{array}{l}F_{(5,50)}=13.10 \\
\boldsymbol{P}<\mathbf{0 . 0 1}\end{array}$ & $\begin{array}{l}F_{(5,50)}=50.13 \\
P<\mathbf{0 . 0 1}\end{array}$ & $\begin{array}{l}F_{(5,50)}=19.49 \\
\boldsymbol{P}<\mathbf{0 . 0 1}\end{array}$ \\
\hline & $\begin{array}{l}\text { treatment } * \\
\text { date }\end{array}$ & $\begin{array}{l}F_{(5,50)}=1.64 \\
P=0.67\end{array}$ & $\begin{array}{l}F_{(5,50)}=1.40 \\
P=0.22\end{array}$ & $\begin{array}{l}F_{(5,50)}=1.94 \\
P=0.10\end{array}$ & $\begin{array}{l}F_{(5,50)}=3.34 \\
\boldsymbol{P}=\mathbf{0 . 0 1}\end{array}$ & $\begin{array}{l}F_{(5,50)}=1.90 \\
P=0.11\end{array}$ & $\begin{array}{l}F_{(5,50)}=2.68 \\
P=0.03\end{array}$ & $\begin{array}{l}F_{(5,50)}=1.95 \\
P=0.10\end{array}$ \\
\hline & treatment & $\begin{array}{l}F_{(1,10)}=4.46 \\
P=0.06\end{array}$ & $\begin{array}{l}F_{(1,10)}=1.07 \\
P=0.33\end{array}$ & $\begin{array}{l}F_{(1,10)}=5.08 \\
P=0.047\end{array}$ & $\begin{array}{l}F_{(1,10)}=1.75 \\
P=0.22\end{array}$ & $\begin{array}{l}F_{(1,10)}=6.37 \\
P=0.03\end{array}$ & $\begin{array}{l}F_{(1,10)}=1.13 \\
P=0.31\end{array}$ & $\begin{array}{l}F_{(1,10)}=4.68 \\
P=0.06\end{array}$ \\
\hline & date & $\begin{array}{l}F_{(5,50)}=18.01 \\
\boldsymbol{P}<\mathbf{0 . 0 1}\end{array}$ & $\begin{array}{l}F_{(5,50)}=6.02 \\
P<\mathbf{0 . 0 1}\end{array}$ & $\begin{array}{l}F_{(5,50)}=2.78 \\
\boldsymbol{P}=\mathbf{0 . 0 3}\end{array}$ & $\begin{array}{l}F_{(5,50)}=30.63 \\
\boldsymbol{P}<\mathbf{0 . 0 1}\end{array}$ & $\begin{array}{l}F_{(5,50)}=5.55 \\
\boldsymbol{P}<\mathbf{0 . 0 1}\end{array}$ & $\begin{array}{l}F_{(5,50)}=29.01 \\
\boldsymbol{P}<\mathbf{0 . 0 1}\end{array}$ & $\begin{array}{l}F_{(5,50)}=18.40 \\
\boldsymbol{P}<\mathbf{0 . 0 1}\end{array}$ \\
\hline & $\begin{array}{l}\text { treatment } * \\
\text { date }\end{array}$ & $\begin{array}{l}F_{(5,50)}=0.69 \\
P=0.64\end{array}$ & $\begin{array}{l}F_{(5,50)}=0.56 \\
P=0.73\end{array}$ & $\begin{array}{l}F_{(5,50)}=0.72 \\
P=0.61\end{array}$ & $\begin{array}{l}F_{(5,50)}=1.15 \\
P=0.35\end{array}$ & $\begin{array}{l}F_{(5,50)}=0.43 \\
P=0.83\end{array}$ & $\begin{array}{l}F_{(5,50)}=1.11 \\
P=0.37\end{array}$ & $\begin{array}{l}F_{(5,50)}=1.36 \\
P=0.26\end{array}$ \\
\hline
\end{tabular}


Table 5. Full statistical results from a two-way repeated measures ANOVA for extracellular enzyme potential from the freshwater sites measured at three depths $(0-10,10-20,20-30 \mathrm{~cm})$ given treatment, species, and date. Significant $(\alpha=0.05)$ results in bold. Data presented as F(numerator degrees of freedom, denominator degrees of freedom $)=F$ value, $P=\mathrm{P}$ value.

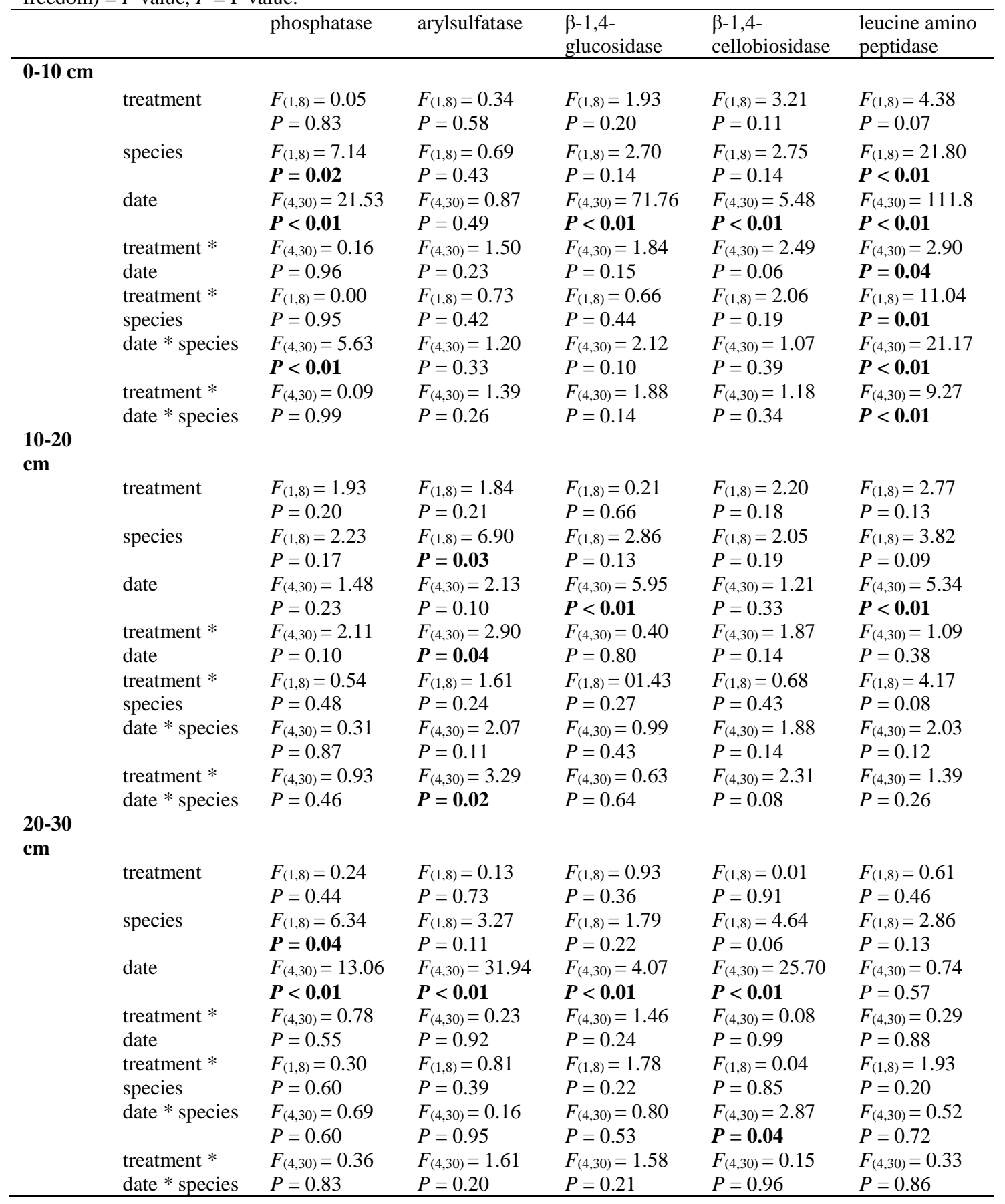


Table 6. Full statistical results from a two-way repeated measures ANOVA for extracellular enzyme potential from the brackish sites measured at three depths $(0-10,10-20,20-30 \mathrm{~cm})$ given treatment and date. Significant $(\alpha=0.05)$ results in bold. Data presented as $\mathrm{F}$ (numerator degrees of freedom, denominator degrees of freedom) $=F$ value, $P=\mathrm{P}$ value.

\begin{tabular}{|c|c|c|c|c|c|c|}
\hline & & phosphatase & arylsulfatase & $\begin{array}{c}\beta-1,4- \\
\text { glucosidase }\end{array}$ & $\begin{array}{c}\beta-1,4- \\
\text { cellobiosidase }\end{array}$ & $\begin{array}{c}\text { leucine amino } \\
\text { peptidase }\end{array}$ \\
\hline \multicolumn{7}{|l|}{$0-10 \mathrm{~cm}$} \\
\hline & treatment & $\begin{array}{l}F_{(1,10)}=0.28 \\
P=0.61\end{array}$ & $\begin{array}{l}F_{(1,10)}=0.01 \\
P=0.92\end{array}$ & $\begin{array}{l}F_{(1,10)}=0.00 \\
P=0.96\end{array}$ & $\begin{array}{l}F_{(1,10)}=0.69 \\
P=0.43\end{array}$ & $\begin{array}{l}F_{(1,10)}=1.03 \\
P=0.33\end{array}$ \\
\hline & date & $\begin{array}{l}F_{(5,50)}=13.73 \\
\boldsymbol{P}<\mathbf{0 . 0 1}\end{array}$ & $\begin{array}{l}F_{(5,50)}=6.97 \\
\boldsymbol{P}<\mathbf{0 . 0 1}\end{array}$ & $\begin{array}{l}F_{(5,50)}=19.31 \\
\boldsymbol{P}<\mathbf{0 . 0 1}\end{array}$ & $\begin{array}{l}F_{(5,49)}=16.59 \\
\boldsymbol{P}<\mathbf{0 . 0 1}\end{array}$ & $\begin{array}{l}F_{(5,50)}=23.23 \\
\boldsymbol{P}<\mathbf{0 . 0 1}\end{array}$ \\
\hline & treatment $*$ date & $\begin{array}{l}F_{(5,50)}=1.87 \\
P=0.11\end{array}$ & $\begin{array}{l}F_{(5,50)}=1.09 \\
P=0.38\end{array}$ & $\begin{array}{l}F_{(5,50)}=0.19 \\
P=0.97\end{array}$ & $\begin{array}{l}F_{(5,49)}=0.18 \\
P=0.97\end{array}$ & $\begin{array}{l}F_{(5,50)}=1.06 \\
P=0.39\end{array}$ \\
\hline \multicolumn{7}{|l|}{$10-20 \mathrm{~cm}$} \\
\hline & treatment & $\begin{array}{l}F_{(1,10)}=0.81 \\
P=0.39\end{array}$ & $\begin{array}{l}F_{(1,10)}=3.21 \\
P=0.10\end{array}$ & $\begin{array}{l}F_{(1,10)}=1.58 \\
P=.24\end{array}$ & $\begin{array}{l}F_{(1,10)}=0.46 \\
P=0.51\end{array}$ & $\begin{array}{l}F_{(1,10)}=1.08 \\
P=0.32\end{array}$ \\
\hline & date & $\begin{array}{l}F_{(5,50)}=6.53 \\
\boldsymbol{P}<\mathbf{0 . 0 1}\end{array}$ & $\begin{array}{l}F_{(5,50)}=10.42 \\
\boldsymbol{P}<\mathbf{0 . 0 1}\end{array}$ & $\begin{array}{l}F_{(5,50)}=23.66 \\
\boldsymbol{P}<\mathbf{0 . 0 1}\end{array}$ & $\begin{array}{l}F_{(5,50)}=9.82 \\
\boldsymbol{P}<\mathbf{0 . 0 1}\end{array}$ & $\begin{array}{l}F_{(5,50)}=1.99 \\
P=0.10\end{array}$ \\
\hline & treatment $*$ date & $\begin{array}{l}F_{(5,50)}=0.66 \\
P=0.66\end{array}$ & $\begin{array}{l}F_{(5,50)}=3.79 \\
\boldsymbol{P}<\mathbf{0 . 0 1}\end{array}$ & $\begin{array}{l}F_{(5,50)}=4.93 \\
P=\mathbf{0 . 0 1}\end{array}$ & $\begin{array}{l}F_{(5,50)}=0.75 \\
P=0.59\end{array}$ & $\begin{array}{l}F_{(5,50)}=0.90 \\
P=0.49\end{array}$ \\
\hline \multicolumn{7}{|l|}{$20-30 \mathrm{~cm}$} \\
\hline & treatment & $\begin{array}{l}F_{(1,10)}=4.33 \\
P=0.06\end{array}$ & $\begin{array}{l}F_{(1,10)}=0.00 \\
P=0.94\end{array}$ & $\begin{array}{l}F_{(1,10)}=2.26 \\
P=0.16\end{array}$ & $\begin{array}{l}F_{(1,10)}=0.17 \\
P=0.69\end{array}$ & $\begin{array}{l}F_{(1,10)}=1.97 \\
P=0.19\end{array}$ \\
\hline & date & $\begin{array}{l}F_{(5,50)}=7.85 \\
\boldsymbol{P}<\mathbf{0 . 0 1}\end{array}$ & $\begin{array}{l}F_{(5,50)}=22.24 \\
\boldsymbol{P}<\mathbf{0 . 0 1}\end{array}$ & $\begin{array}{l}F_{(5,50)}=10.97 \\
\boldsymbol{P}<\mathbf{0 . 0 1}\end{array}$ & $\begin{array}{l}F_{(5,50)}=27.89 \\
\boldsymbol{P}<\mathbf{0 . 0 1}\end{array}$ & $\begin{array}{l}F_{(5,50)}=2.07 \\
P=0.08\end{array}$ \\
\hline & treatment $*$ date & $\begin{array}{l}F_{(5,50)}=1.84 \\
P=0.12\end{array}$ & $\begin{array}{l}F_{(5,50)}=0.81 \\
P=0.55\end{array}$ & $\begin{array}{l}F_{(5,50)}=5.12 \\
\boldsymbol{P}<\mathbf{0 . 0 1}\end{array}$ & $\begin{array}{l}F_{(5,50)}=0.22 \\
P=0.95\end{array}$ & $\begin{array}{l}F_{(5,50)}=2.06 \\
P=0.09\end{array}$ \\
\hline
\end{tabular}


Table 7. Average ( \pm standard error) extracellular enzyme activities $\left(\mu \mathrm{mol} \mathrm{g}{ }^{-1} \mathrm{~h}^{-1}\right)$ and microbial biomass carbon $\left(\mathrm{C} ; \mu \mathrm{mol} \mathrm{L} \mathrm{L}^{-1} \mathrm{~g}^{-1}\right)$ from the freshwater site measured on bulk soil collected after 2 years of saltwater manipulations. Soil enzyme activities were measured at three depths (0-10, 10-20, and 20-30 cm) and compared between control chambers and saltwater treatment chambers using a Welch's two-sample $t$-test and an $\alpha$ $=0.05$. Significant differences are bolded.

\begin{tabular}{|c|c|c|c|}
\hline & control & treatment & significance \\
\hline \multirow{6}{*}{$\begin{array}{l}0-10 \mathrm{~cm} \\
\text { phosphatase } \\
\text { arylsulfatase } \\
\beta-1,4-\text { glucosidase } \\
\beta-1,4-\text { cellobiosidase } \\
\text { leucine aminopeptidase }\end{array}$} & & & \\
\hline & $3.89(0.71)$ & $3.51(1.53)$ & $P=0.83 ; T_{(7.4)}=0.22$ \\
\hline & $3.26(0.56)$ & $3.35(0.85)$ & $P=0.93 ; T_{(8.0)}=0.08$ \\
\hline & $5.91(0.88)$ & $3.46(0.69)$ & $P=0.11 ; T_{(5.4)}=1.92$ \\
\hline & $2.66(1.27)$ & $0.62(0.16)$ & $P=0.28 ; T_{(3.1)}=1.31$ \\
\hline & $0.01(0.00)$ & $0.04(0.02)$ & $P=0.10 ; T_{(6.0)}=1.94$ \\
\hline microbial biomass $\mathrm{C}$ & 13909 (2893) & $21010(2953)$ & $\begin{array}{l}P=0.12 ; T_{(10.0)}= \\
1.72\end{array}$ \\
\hline \multirow{4}{*}{$\begin{array}{l}10-20 \mathrm{~cm} \\
\text { phosphatase } \\
\text { arylsulfatase } \\
\beta-1,4 \text {-glucosidase } \\
\beta-1,4 \text {-cellobiosidase } \\
\text { leucine aminopeptidase }\end{array}$} & $0.58(0.11)$ & $1.11(0.35)$ & $P=0.21 ; T_{(6,4)}=1.39$ \\
\hline & $1.03(0.09)$ & $1.67(0.23)$ & $P=0.04 ; T_{(7.1)}=2.53$ \\
\hline & $2.91(0.36)$ & $3.21(1.02)$ & $P=0.80 ; T_{(6.7)}=0.26$ \\
\hline & $0.58(0.09)$ & $0.43(0.20)$ & $\begin{array}{l}P=0.53 ; T_{(7.2)}=0.66 \\
N A\end{array}$ \\
\hline $\begin{array}{l}\text { microbial biomass } C \\
20-30 \mathrm{~cm}\end{array}$ & $\begin{array}{l}0.00(0.00) \\
15742(1890)\end{array}$ & $\begin{array}{l}0.00(0.00) \\
15946(2272)\end{array}$ & $P=0.95 ; T_{(9.7)}=0.07$ \\
\hline phosphatase & $0.13(0.06)$ & $0.60(0.31)$ & $P=0.19 ; T_{(5.6)}=1.48$ \\
\hline arylsulfatase & $1.53(0.46)$ & $1.34(0.29)$ & $P=0.78 ; T_{(4.5)}=0.29$ \\
\hline$\beta$-1,4-glucosidase & $2.69(0.61)$ & $2.69(0.75)$ & $P=1.00 ; T_{(7.5)}=0.00$ \\
\hline \multirow{2}{*}{$\begin{array}{l}\beta \text {-1,4-cellobiosidase } \\
\text { leucine aminopeptidase }\end{array}$} & $0.36(0.36)$ & $0.40(0.13)$ & $P=0.90 ; T_{(5.5)}=0.13$ \\
\hline & $0.00(0.00)$ & $0.01(0.01)$ & $P=0.09 ; T_{(5.0)}=2.08$ \\
\hline
\end{tabular}


Table 8. Average ( \pm standard error) extracellular enzyme activities $\left(\mu \mathrm{mol} \mathrm{g} \mathrm{g}^{-1} \mathrm{~h}^{-1}\right)$ and microbial biomass carbon $\left(\mathrm{C} ; \mu \mathrm{mol} \mathrm{L} \mathrm{L}^{-1} \mathrm{~g}^{-1}\right)$ from the brackish site measured on bulk soil collected after 2 years of saltwater manipulations. Soil enzyme activities were measured at three depths (0-10, 10-20, and 20$30 \mathrm{~cm}$ ) and compared between control chambers and saltwater treatment chambers using a Welch's two-sample $t$-test and an $\alpha=0.05$. Significant differences are bolded.

\begin{tabular}{llll}
\hline & control & treatment & significance \\
\hline $0-10 \mathrm{~cm}$ & & & \\
phosphatase & $2.80(0.96)$ & $2.61(0.61)$ & $P=0.87 ; T_{(8.5)}=0.17$ \\
arylsulfatase & $2.07(0.47)$ & $2.16(0.24)$ & $P=0.88 ; T_{(7.4)}=0.16$ \\
$\beta-1,4$-glucosidase & $1.68(0.41)$ & $1.87(0.17)$ & $P=0.67 ; T_{(6.8)}=0.45$ \\
$\beta-1,4-$ cellobiosidase & $0.23(0.04)$ & $0.24(0.03)$ & $P=0.75 ; T_{(9.9)}=0.33$ \\
leucine aminopeptidase & $0.01(0.01)$ & $0.00(0.00)$ & $P=0.36 ; T_{(5.0)}=1.00$ \\
microbial biomass C & $1837(787)$ & $1294(889)$ & $P=0.66 ; T_{(9.9)}=0.46$ \\
$10-20$ cm & & & \\
phosphatase & $1.30(0.45)$ & $1.63(0.57)$ & $P=0.66 ; T_{(9.4)}=0.46$ \\
arylsulfatase & $1.08(0.11)$ & $1.71(0.55)$ & $P=0.31 ; T_{(5.4)}=1.12$ \\
$\beta-1,4$-glucosidase & $1.51(0.38)$ & $1.89(0.45)$ & $P=0.53 ; T_{(9.7)}=0.64$ \\
$\beta-1,4-c e l l o b i o s i d a s e$ & $0.14(0.02)$ & $0.17(0.03)$ & $P=0.42 ; T_{(8.3)}=0.75$ \\
leucine aminopeptidase & $0.00(0.00)$ & $0.00(0.00)$ & $N A$ \\
microbial biomass C & $2097(608)$ & $1196(447)$ & $P=0.26 ; T_{(9.2)}=1.19$ \\
20-30 cm & & \\
phosphatase & $0.45(0.22)$ & $0.60(0.22)$ & $P=0.62 ; T_{(9.9)}=0.50$ \\
arylsulfatase & $0.51(0.09)$ & $0.75(0.16)$ & $P=0.21 ; T_{(7.9)}=1.35$ \\
$\beta-1,4$-glucosidase & $1.53(0.13)$ & $1.68(0.13)$ & $P=0.42 ; T_{(9.9)}=0.84$ \\
$\beta-1,4-c e l l o b i o s i d a s e$ & $0.11(0.02)$ & $0.16(0.05)$ & $P=0.31 ; T_{(6.7)}=1.10$ \\
leucine aminopeptidase & $0.00(0.00)$ & $0.00(0.00)$ & $N A$ \\
\hline
\end{tabular}


Table 9. Average ( \pm standard error) percent $(\%)$ carbon $(\mathrm{C})$, phosphorus $(\mathrm{P})$, and nitrogen $(\mathrm{N})$ in bulk soil from the freshwater and brackish sites collected after 2 years of pulsed saltwater additions. Percent $\mathrm{C}, \mathrm{N}$, and $\mathrm{P}$ were measured at three depths $(0-10,10-20$, and $20-30 \mathrm{~cm})$ and compared between control chambers and saltwater treatment chambers using a Welch's two-sample $t$-test and an $\alpha=0.05$. Significant differences are bolded.

\begin{tabular}{|c|c|c|c|}
\hline & control & treatment & significance \\
\hline \multicolumn{4}{|c|}{ Freshwater site } \\
\hline \multicolumn{4}{|c|}{$0-10 \mathrm{~cm}$} \\
\hline$\% \mathrm{C}$ & $40.6(2.7)$ & $35.2(2.9)$ & $P<0.02 ; t_{(10.0)}=4.06$ \\
\hline$\% \mathrm{~N}$ & $3.29(0.18)$ & $3.29(0.18)$ & $P=0.97 ; t_{(10.0)}=0.04$ \\
\hline$\% \mathrm{P}$ & $0.052(0.007)$ & $0.057(0.006)$ & $P=0.23 ; t_{(10.0)}=1.26$ \\
\hline \multicolumn{4}{|c|}{$10-20 \mathrm{~cm}$} \\
\hline$\% \mathrm{C}$ & $34.6(5.5)$ & $31.0(4.4)$ & $P=0.37 ; t_{(8.8)}=0.93$ \\
\hline$\% \mathrm{~N}$ & $2.80(0.27)$ & $3.00(0.23)$ & $P=0.19 ; t_{(9.7)}=1.41$ \\
\hline$\% \mathrm{P}$ & $0.039(0.008)$ & $0.052(0.008)$ & $P=0.02 ; t_{(10.0)}=2.75$ \\
\hline \multicolumn{4}{|c|}{$20-30 \mathrm{~cm}$} \\
\hline$\% \mathrm{C}$ & $31.1(5.5)$ & $25.9(6.1)$ & $P=0.19 ; t_{(10.0)}=1.39$ \\
\hline$\% \mathrm{~N}$ & $2.51(0.34)$ & $2.55(0.50)$ & $P=0.86 ; t_{(8.8)}=0.17$ \\
\hline$\% \mathrm{P}$ & $0.040(0.010)$ & $0.042(0.010)$ & $P=0.66 ; t_{(10.0)}=0.45$ \\
\hline \multicolumn{4}{|c|}{ Brackish site } \\
\hline \multicolumn{4}{|c|}{$0-10 \mathrm{~cm}$} \\
\hline$\% \mathrm{C}$ & $42.7(0.9)$ & $43.1(1.0)$ & $P=0.34 ; t_{(5.2)}=1.04$ \\
\hline$\% \mathrm{~N}$ & $2.47(0.31)$ & $2.17(0.25)$ & $P=0.10 ; t_{(10.0)}=1.84$ \\
\hline$\% \mathrm{P}$ & $0.052(0.007)$ & $0.044(0.011)$ & $P=0.18 ; t_{(8.6)}=1.44$ \\
\hline \multicolumn{4}{|c|}{$10-20 \mathrm{~cm}$} \\
\hline$\% \mathrm{C}$ & $43.1(1.1)$ & $42.9(2.1)$ & $P=0.40 ; t_{(4.3)}=0.93$ \\
\hline$\% \mathrm{~N}$ & $2.35(0.24)$ & $1.92(0.28)$ & $P=0.02 ; t_{(7.9)}=2.89$ \\
\hline$\% \mathrm{P}$ & $0.039(0.008)$ & $0.033(0.004)$ & $P=0.15 ; t_{(7.2)}=1.57$ \\
\hline \multicolumn{4}{|c|}{$20-30 \mathrm{~cm}$} \\
\hline$\% \mathrm{C}$ & $42.6(0.8)$ & $42.1(1.6)$ & $P=0.74 ; t_{(6.6)}=0.35$ \\
\hline$\% \mathrm{~N}$ & $2.10(0.22)$ & $1.99(0.21)$ & $P=0.40 ; t_{(10.0)}=0.88$ \\
\hline$\% \mathrm{P}$ & $0.031(0.005)$ & $0.029(0.005)$ & $P=0.56 ; t_{(10.0)}=0.60$ \\
\hline
\end{tabular}




\section{FIGURES}

Figure 1. Location of the freshwater (FW) and brackish (BW) sites within Everglades National Park (A). Example of the experimental chambers installed in the marsh (B). Design of the mesh litterbags before deployment in the field. (C).

Figure 2. Hypothesized path model describing how salinity affects root litter breakdown rates. Arrows indicate hypothesized causal links between variables. The structured set of linear equations that correspond to each response variable can be described based on the links associated with each variable (e.g., microbial activity salinity + porewater constituents, porewater constituents $\sim$ salinity). We hypothesized that microbial activity mediates effects of salinity on root litter breakdown because of the direct effects of salinity stress on microbial activity and indirectly through changes in concentrations of porewater constituents.

Figure 3. Percent ash-free dry mass (AFDM) remaining, \% carbon $(\mathrm{C})$, \% nitrogen $(\mathrm{N})$, and $\%$ phosphorus $(\mathrm{P})$ of root litter material collected from litterbags at the freshwater site from five retrieval dates and three depths $(0-10,10-20,20-30 \mathrm{~cm})$. Results from the repeated measures ANOVA can be found in Table 3.

Figure 4. Percent ash-free dry mass (AFDM) remaining, \% carbon $(\mathrm{C}), \%$ nitrogen $(\mathrm{N})$, and \% phosphorus (P) of root litter material collected from litterbags at the brackish site from five retrieval dates and three depths $(0-10,10-20,20-30 \mathrm{~cm})$. Results from the repeated measures ANOVA can be found in Table 4. 
Figure 5. Extracellular enzyme activities of phosphatase, arylsulfatase, $\beta$-1,4-glucosidase, $\beta$-1,4-cellobiosidase, and leucine aminopeptidase measured on the collected litterbag material at the freshwater site. Full statistical results from the repeated measures ANOVA are reported in Table 5.

Figure 6. Extracellular enzyme activities of phosphatase, arylsulfatase, $\beta$-1,4-glucosidase, $\beta$-1,4-cellobiosidase, and leucine aminopeptidase measured on the collected litterbag material at the brackish site. Full statistical results from the repeated measures ANOVA are reported in Table 6.

Figure 7. The best-supported model for 30-d litter breakdown $\left(\mathrm{k} \mathrm{d}^{-1}\right)$ for the brackish site. Standardized path coefficients are reported, and the sign of the path coefficient indicates the direction of the correlation between variables. The best-supported model explains $44 \%$ of the variation in litter breakdown rates. Dashed arrows indicate nonsignificant path coefficients $(P>0.05)$. 
Figure 1.

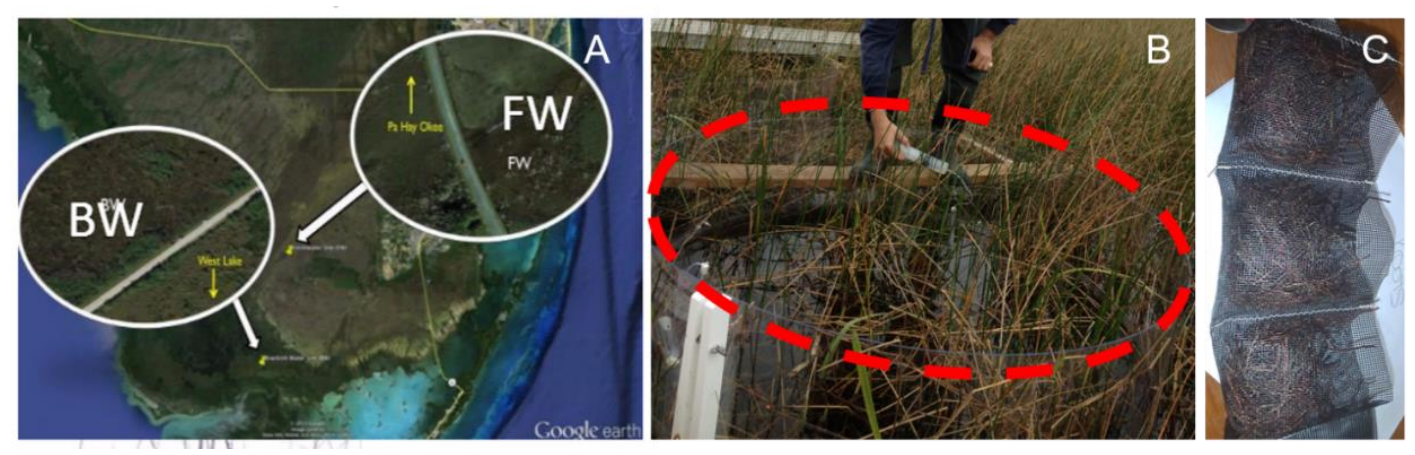


Figure 2.

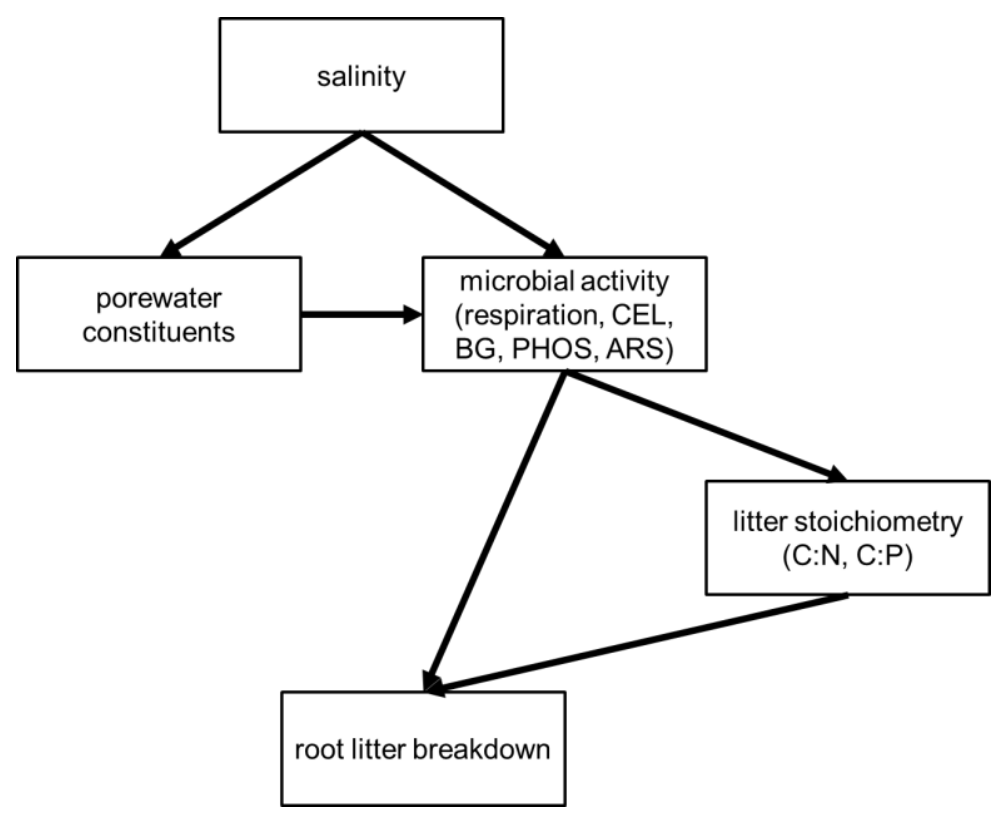


Figure 3.
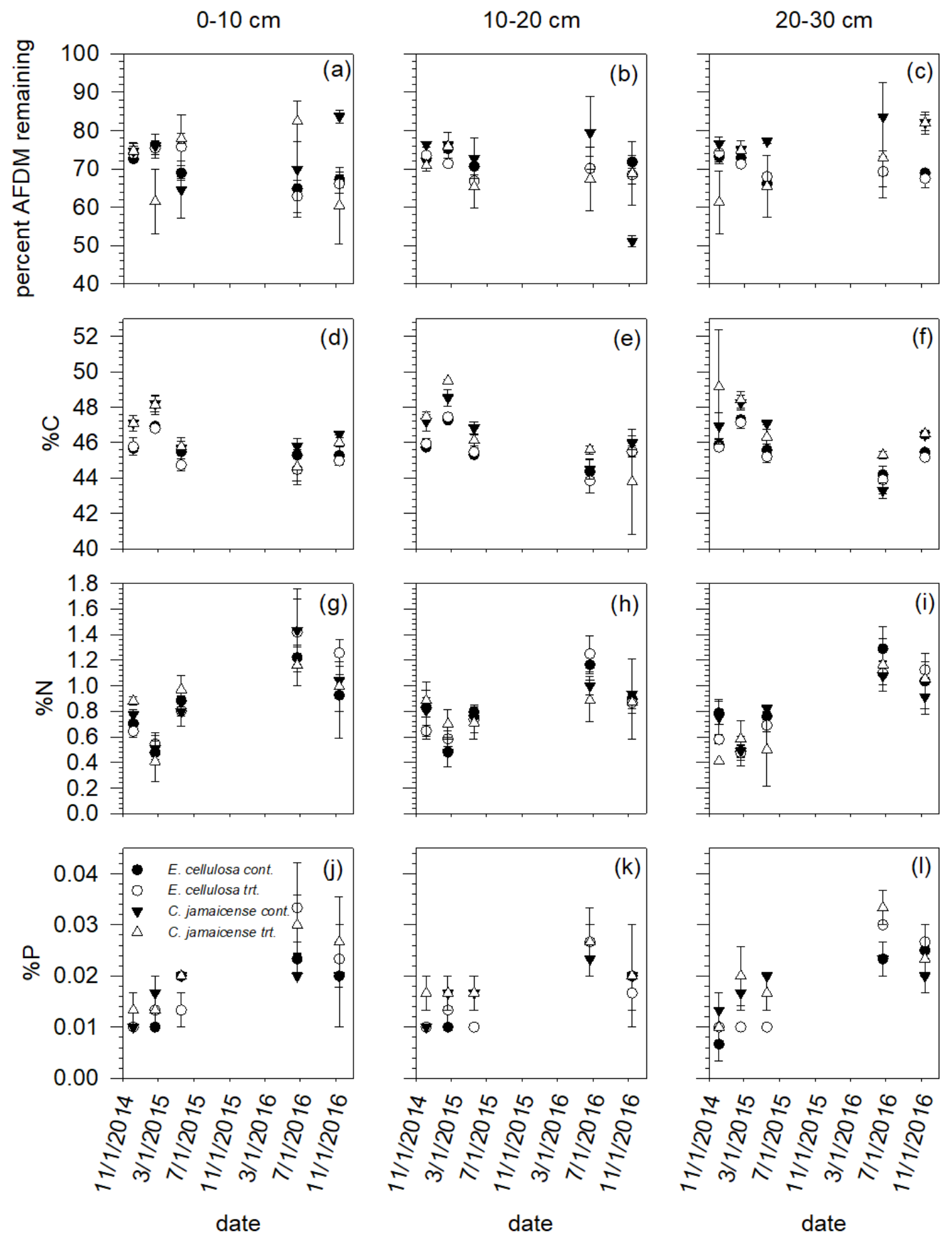
Figure 4.

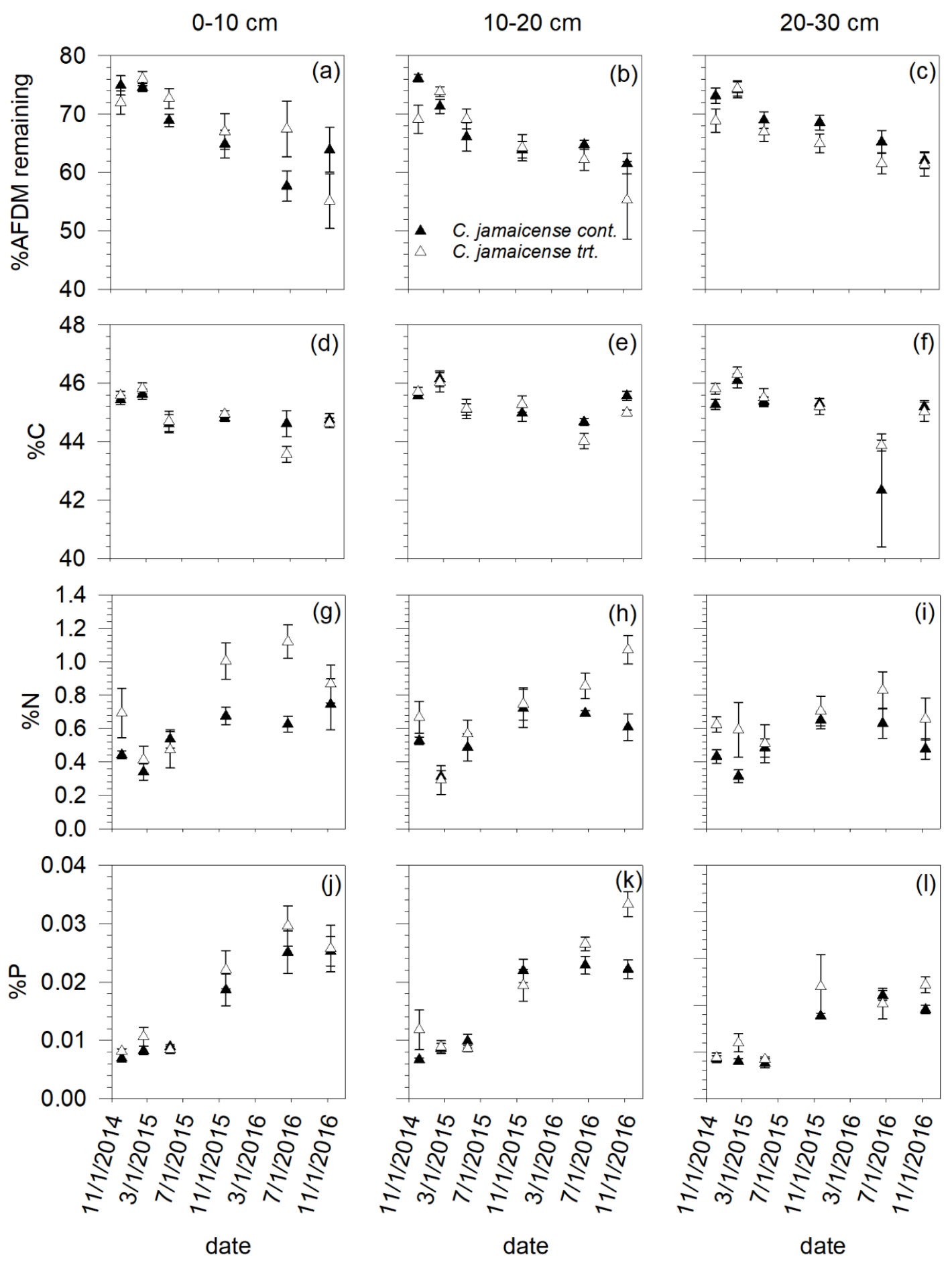


Figure 5.
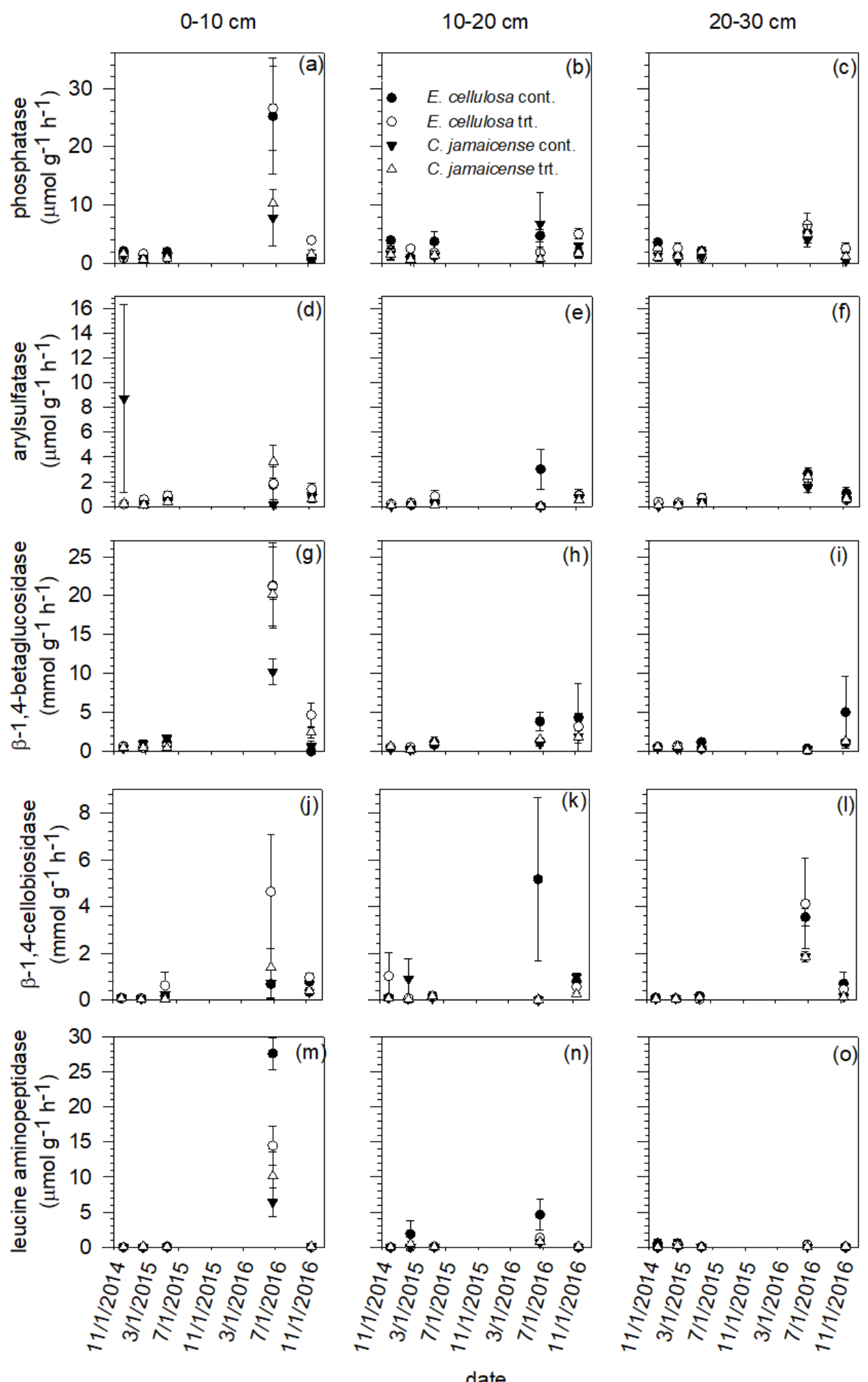
Figure 6.
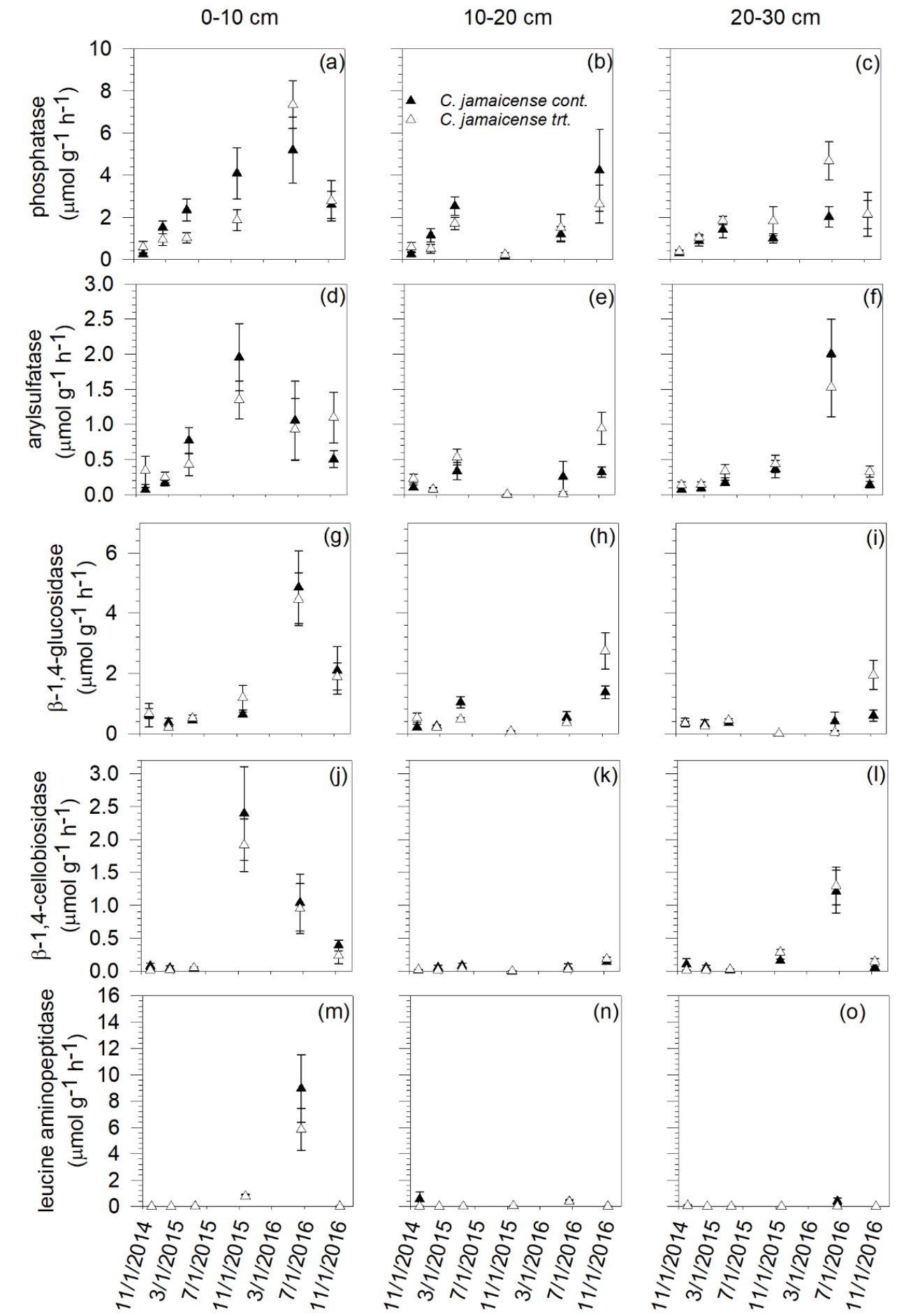

date 
Figure 7.

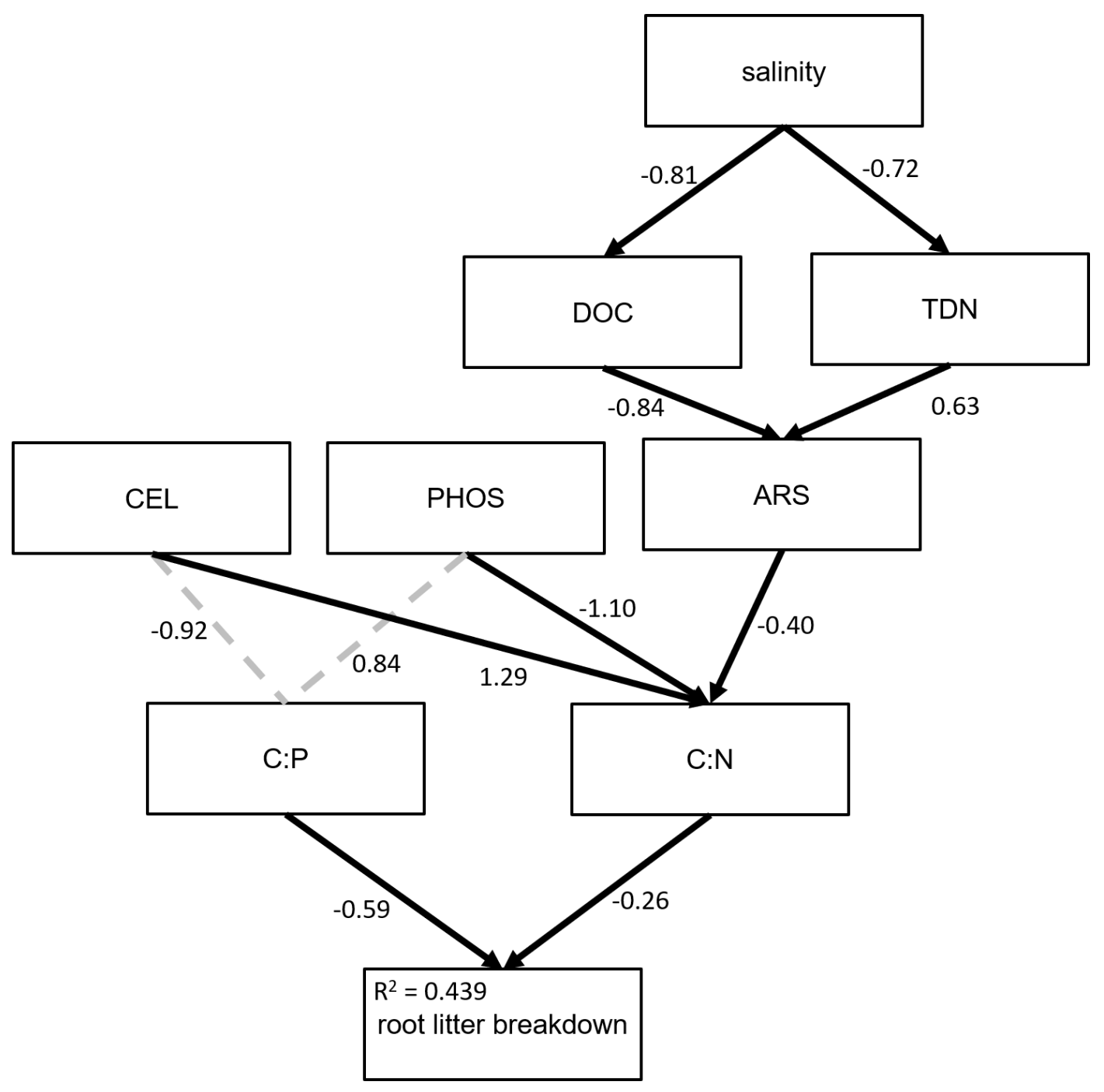




\section{CHAPTER IV}

LEGACIES OF EXPOSURE TO SALTWATER DRIVE DIFFERENTIAL SOIL MICROBIAL REPONSES TO SALINITY AND PHOSPHORUS 
Title: Legacies of exposure to saltwater drive differential soil microbial responses to salinity and phosphorus

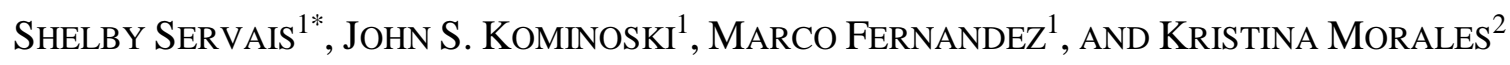

${ }^{1}$ Department of Biological Sciences and Southeast Environmental Research Center,

Florida International University, Miami, Florida 33199 USA

${ }^{2}$ Department of Biology, The University of North Carolina at Greensboro, Greensboro, North Carolina 27402 USA

*Email: sserv005@fiu.edu 


\section{ABSTRACT}

Biogeochemical cycling in soils is fundamentally linked to the metabolism of microbial communities. Saltwater intrusion into coastal wetlands of the Florida Everglades will increase salinity and phosphorus $(\mathrm{P})$ with uncertain effects on soil microbial activities and biogeochemical processes. Understanding how the interaction of salinity stress and $\mathrm{P}$ subsidy affects soil microbial biogeochemical cycles will inform how coastal wetlands are responding to changing environmental conditions. In experimental mesocosms, we added crossed gradients of elevated concentrations of $\mathrm{P}\left(0,20,40,60,80 \mu \mathrm{g} \mathrm{L}^{-1}\right)$ and salinity to freshwater $(0,4,7,12,16 \mathrm{ppt})$ and brackish peat soils $(10,14,17,22,26 \mathrm{ppt})$ for 35 days. Throughout the incubation, we quantified changes in water constituents, soil microbial extracellular enzyme activities (EEAs), respiration rates, microbial biomass carbon $(\mathrm{C})$, and soil $\mathrm{C}$ and nutrient (nitrogen, $\mathrm{N} ; \mathrm{P}$ ) concentrations and stoichiometric ratios. Freshwater and brackish soils showed differential responses to salinity, SRP and DOC increased with salinity in freshwater incubations but decreased with salinity in brackish incubations. Freshwater soils displayed a P uptake threshold and only removed $\mathrm{P}$ from the water column at low salinity and after $\mathrm{P}$ treatment level reached $40 \mu \mathrm{g} \mathrm{L}^{-1}$. Freshwater microbial EEAs, respiration rates and microbial biomass $\mathrm{C}$ were consistently higher compared to those from brackish soils across all treatment levels. Increased salinity decreased freshwater soil $\% \mathrm{C}$, but did not affect $\% \mathrm{~N}, \% \mathrm{P}$, or stoichiometric ratios. Elemental concentrations and stoichiometric ratios of brackish soils were not affected by added salinity and P, indicating saltwater intrusion may have already altered these soils. Microbial respiration rates decreased with added salinity in freshwater soils and increased with added $\mathrm{P}$ in brackish soils. Microbial biomass $\mathrm{C}$ of brackish soils 
increased with salinity; whereas freshwater microbial biomass $\mathrm{C}$ was unaffected. The results from these comparative mesocosm experiments illustrate differential subsidy and stress responses of soil microbes in freshwater and brackish wetland soils to saltwater intrusion, indicating heterogeneous effects on biogeochemical cycling among coastal wetlands.

Keywords: sea-level rise; Florida Everglades; extracellular enzymes; response surface

\section{INTRODUCTION}

Environmental perturbations are ubiquitous across ecosystems and shape ecological organization and function (White and Jentsch 2001). Ecosystem processes are continuously influenced by the presence and interaction of stressors and subsidies (Odum et al. 1979). Environmental perturbations are generalized into two broad categories of usable and toxic inputs. Usable inputs, also considered subsidies, enhance ecosystem function at low levels of exposure but diminish function at higher levels. Toxic inputs, also referred to as stressors, immediate adverse effects on ecosystem function (Odum et al. 1979). Climate change will alter the intensity and frequency of perturbation patterns and expose ecosystems to novel combinations of subsidies and stressors. For example, global climate change is simultaneously exposing coastal wetlands to multiple environmental perturbations (Green et al. 2017).

The intensity, duration, and frequency of exposure to disturbance can influence ecosystem function. Climate change is altering the dynamics of disturbance leading to uncertain ecosystem responses (Turner 2010, Trumbore et al. 2015). While ecosystems have some capacity to recover structure and functioning following disturbance (Holling 
1973) disturbances can elicit changes in ecosystem state (Scheffer et al. 2001). Legacies of previous exposure to disturbance interact to shape ecosystem response to new disturbances (Franklin et al. 2000). Ecological memory, the information, and materials that persist after disturbance, influence ecosystem responses to future disturbances (Padisak 1992, Johnstone et al. 2016). Ecosystem processes within the Florida Coastal Everglades is affected by the legacy of land management and new threat from sea level rise will influence how the ecosystem responds to environmental disturbances. There is a gradient in exposure, to saltwater intrusion in the Everglades from freshwater marshes that have never been exposed to saltwater intrusion to highly perturbed brackish marshes experiencing soil collapse. However, we lack an understanding of how legacies of disturbance influence ecosystem function in the face of further disturbance.

Soil microorganisms are considered the first responders to environmental perturbations because of their high surface area to volume ratio, permeable membrane, and quick turnover rates. Three main hypotheses have been presented for how ecological disturbances can affect soil microbial communities (Herbert et al. 2015). First, follows the logic of functional redundancy within microbial communities, and would predict perturbations would result in shifts in species composition without a change in microbial function and processing rates (Hobbie 1988, Hart et al. 1991, Nielson et al. 2003). Second, is that microbial community composition will remain unchanged but the function will be altered as individual species adapt, become dormant, modify gene expression, and display functional plasticity (Edmonds et al. 2009, Nelson et al. 2015). The final hypothesis is that microbial community structure and function will change in tandem in response to perturbations (Jackson and Vallaire 2009). These three hypotheses are not 
mutually exclusive and provide insight into how microbial structure and function may respond differently to subsidies and stressors.

Soil microorganisms contribute to ecosystem function by driving $\mathrm{C}$ and nutrient cycling through the release of extracellular enzymes to meet metabolic demands for $\mathrm{C}$ and nutrients (Dick et al. 1994, Sinsabaugh et al. 2002, Penton and Newman 2007)). Current environmental conditions within the Everglades and other peatlands control extracellular enzyme activities (EEAs) and determine current rates of biogeochemical cycling (Freeman et al. 2001). Saltwater intrusion changes microbially-mediated biogeochemical cycling in coastal wetlands, changing both subsidies and stressors (Flower et al. 2017). Enzyme activities are often suppressed when exposed to elevated salinity (Frankenberger and Bingham 1982, Jackson and Vallaire 2009), as microbes divert resources to the production of osmolytes and consequentially reduce production of extracellular enzymes (Kempf and Bremer 1998). Phosphorus enrichment studies find an inverse relationship with phosphatase enzyme activities (Speiers and McGill 1979, Wright and Reddy 2001, Morrison et al. 2016) and positive relationships with other enzymes activities (Rejmánková and Sirova 2007). The effects of simultaneous exposure to osmotic stress and increased nutrient availability on microbial function is unclear. In the Everglades, and other coastal freshwater wetlands, changes in extracellular enzyme activities may lead to long-term-effects on collapse and/or accumulation of C-storing peat soils (Penton and Newman 2007).

A comprehensive approach to understanding effects of saltwater intrusion requires rigorously testing responses across gradients of subsidies and stressors among ecosystems. To examine simultaneous impacts of increased salinity and P on soil 
microbial extracellular enzyme activities, microbial biomass $\mathrm{C}$, soil respiration, and soil elemental composition we experimentally incubated freshwater and brackish soils to crossed gradients in added concentrations of salinity and P. We predicted that salinity would suppress EEAs, microbial biomass $\mathrm{C}$, and respiration rates based on previous work that has shown salinity to suppress microbial functioning in the Everglades (Servais et al. in review). We predicted increasing $\mathrm{P}$ would enhance microbial EEAs, soil respiration,

and microbial biomass $\mathrm{C}$ in these $\mathrm{P}$ limited soils. We predicted that brackish EEAs would have a smaller magnitude response to the salinity stress and $\mathrm{P}$ subsidies compared to freshwater soils because of previous exposure ("ecological memory") to saltwater and adaptions of these microbial communities. We predicted salinity would act as a stressor and suppress brackish and freshwater EEAs. We predicted $\mathrm{P}$ would increase $\mathrm{C}-, \mathrm{N}-$, and S- acquiring enzymes and decrease P-acquiring enzymes as microbial demand for $\mathrm{C}, \mathrm{N}$ and $\mathrm{S}$ would increase relative to demand for $\mathrm{P}$. We predicted increased salinity would lower soil \%C and increased $\mathrm{P}$ would increase soil \%P. We predicted freshwater soils would be lower in $\mathrm{P}$ and consequently have increased $\mathrm{P}$ removal than brackish soils. We also predicted that freshwater soils would have higher $\% \mathrm{C}$ and therefore be more susceptible to C loss with salinity exposure.

\section{METHODS}

\section{Soil sampling and preparation}

We collected surficial soil samples from a freshwater wetland in the Florida Everglades (25 46' 06.1" N, 80 28' 56.2" W) in July 2015 and a brackish wetland in Everglades National Park (25 13' 13.4” N, 80 50'36.7” W) in June 2016. We transported 
the soil to an experimental outdoor mesocosm facility located in Key Largo, Florida. We distributed soil samples into 100 separate $125-\mu \mathrm{m}$ mesh containers (hereafter soil container, Figure 1). We randomly assigned each soil container to a treatment level (described below).

\section{Experimental design}

Incubation chambers were designed using modified plastic gallon jugs to simulate a scale model of the environmental conditions that could be present in areas of the Florida Everglades subjected to increased levels of P and salinity (Figure 1). We placed four soil containers in each incubation chamber. Each incubation chamber received a specific combination of $\mathrm{P}$ and salinity, to develop a response surface. Twenty-five separate dosing mixtures were made, with four increasing levels of phosphorus and salinity (Figure 1). The P solution was mixed up using diluted phosphoric acid. For salinity control, Instant Ocean ${ }^{\circledR}$ was used in varying concentrations to attain the desired gradient. The incubation chambers were dosed every other day with 0.5 liters of the corresponding solution.

\section{Physicochemical conditions}

We collected monthly surface water samples (filtered) weekly from each incubation chamber $(n=25)$. Filtered surface water samples were collected in a plastic syringe and filtered onsite through a $0.7-\mu \mathrm{m}$ glass fiber filter (GF/F) into a $60 \mathrm{~mL}$ HDPE sample bottle. All water samples were stored at $-20^{\circ} \mathrm{C}$ until analyzed at the Southeast Environmental Research Center, Nutrient Analysis Laboratory. Samples were analyzed 
for dissolved organic $\mathrm{C}$ (DOC), dissolved inorganic nitrogen $\left(\mathrm{N}+\mathrm{N}, \mathrm{NO}_{3}{ }^{-}, \mathrm{NO}_{2}{ }^{-}, \mathrm{NH}_{4}{ }^{+}\right.$), and soluble reactive $\mathrm{P}$ (SRP). Dissolved inorganic $\mathrm{N}$ and SRP parameters were analyzed on an Alpkem RFA 300 auto-analyzer (OI Analytical, College Station, Texas, USA) and DOC was analyzed with a Shimadzu 5000 TOC Analyzer (Shimadzu Scientific Instruments, Columbia, Maryland, USA).

\section{Soil elemental stoichiometry}

Ground soil material was subsampled from samples collected during week 2 and 5 , oven-dried $\left(60^{\circ} \mathrm{C}\right)$ for $48 \mathrm{~h}$, weighed, combusted $\left(550^{\circ} \mathrm{C}\right.$ for four $\left.\mathrm{h}\right)$, and re-weighed to determine ash-free dry mass (AFDM). Carbon and $\mathrm{N}$ content were analyzed using a Carlo Erba NA 1500 CHN Analyser (Carlo Erba, Milan, Italy). Phosphorus content was analyzed using the ash/acid extraction method followed by spectrophotometric analysis using the ascorbic acid method (Allen 1974, APHA 1998). We estimated elemental composition $(\% \mathrm{C}, \% \mathrm{~N}$, and \%P) and stoichiometry (C:N, C:P, and $\mathrm{N}: \mathrm{P})$. All elemental compositions were calculated from the molar mass.

\section{Extracellular enzyme activities}

Extracellular enzyme activities were measured on initial, week 2, and week 5 soil samples. We measured the fluorometric activities of extracellular phosphatase, arylsulfatase, $\beta$-1,4-glucosidase, $\beta$-1,4-cellobiosidase, and leucine aminopeptidase using the substrates described in Servais et al. (in review). Soil microbial enzyme activities were assayed using previously described methods (Saiya-Cork et al. 2002). Briefly, soil sub-samples were collected (approximately $1 \mathrm{~g}$ ) from each soil container, homogenized 
in $60 \mathrm{~mL}$ of $50 \mathrm{mM}$ sodium acetate buffer, and loaded onto a 96-well plate with the appropriate substrate (Servais et al. in review). Fluorescence was read at $365 \mathrm{~nm}$ excitation and $450 \mathrm{~nm}$ emission using a Synergy $\mathrm{H} 1$ microplate reader (BioTek, Winooski, Vermont, USA). We incorporated blanks and controls within each microplate to account for autofluorescence and quenching.

\section{Soil microbial respiration rates and biomass carbon}

We measured microbial respiration from soils collected on week 2 and week 5. Approximately $2.5 \mathrm{~g}$ of weighed wet soils were placed in respiration chambers $(60 \mathrm{~mL})$. The chambers were filled with either the freshwater or saltwater sources depending on the sample's assigned treatment to remove headspace and incubated at room temperature $\left(24{ }^{\circ} \mathrm{C}\right)$ for $2 \mathrm{~h}$. Chambers filled only with the source water served as blanks. Oxygen concentrations were measured at the start and end of the incubation period to determine the rate of oxygen consumption. Soil respiration was determined by subtracting the change in oxygen concentrations in control chambers from the change in oxygen consumption in the samples to account for respiration in the water.

To estimate the mass of the living microorganisms within the soil, we determined the microbial biomass $\mathrm{C}$ using chloroform fumigation and potassium sulfate extraction methods following Vance et al. (1987). We measured microbial biomass C on soil samples from week 2 and week 5 collections. Dissolved organic C samples were analyzed with a Shimadzu 5000 TOC Analyzer (Shimadzu Scientific Instruments, Columbia, Maryland, USA). We calculated microbial biomass $\mathrm{C}$ as the difference in DOC between non-fumigated and fumigated samples. 


\section{Data analyses}

Linear fixed effects models were used to assess effects of soil type (freshwater or brackish), added $\mathrm{P}$, and added saltwater, and $\mathrm{P} \times$ salt interaction on response variables (biomass C, EEAs, respiration rate, litter stoichiometry). Interaction of saltwater and $\mathrm{P}$ was included in models with $\mathrm{N}$ and $\mathrm{P}$ to determine the interdependence of the simultaneous exposure to both stress and subsidy. The linear fixed effects models were performed in RStudio (R Core Team 2017 version 3.3.3). We compared dissolved water constituents, EEAs, microbial biomass $\mathrm{C}$, soil respiration rates, and soil elemental stoichiometry against salinity and P treatment levels using multiple linear regressions. The multiple linear regression analyses were performed in Sigma Plot (Systat Software, San Jose, CA).

\section{RESULTS}

\section{Physicochemical conditions}

Best models of $\mathrm{N}+\mathrm{N}$ were salt $+\mathrm{P}+$ soil type + week and salt + soil type + week which provides evidence for additive effects of salinity and $\mathrm{P}$, temporal variation, and differences between brackish and freshwater soils (Table 1). The best model for both $\mathrm{NO}_{3}{ }^{-}$and $\mathrm{NO}_{2}{ }^{-}$was salt $\times$soil type $\times$week which provides evidence for interactive effects of salinity, soil type, and time on $\mathrm{NO}_{3}{ }^{-}$and $\mathrm{NO}_{2}{ }^{-}$in the water column (Table 1). The best model for $\mathrm{NH}_{4}{ }^{+}$was salt $\times \mathrm{P} \times$ soil type $\times$ week which indicates that it is particularly sensitive to interactions between salinity, $\mathrm{P}$, soil type, and time (Table 1). The best models of SRP included salt $\times$ soil type and salt $\times \mathrm{P} \times$ soil type indicating that soil type, 
$\mathrm{P}$, and salinity interactions are particularly useful at predicting SRP within the water column (Table 1). The best model of DOC was salt $\times$ soil type $\times$ week which provides evidence for only interactive effects of salinity, soil type, and time and little influence of P availability in DOC concentrations in the water column (Table 1).

The $\mathrm{N}+\mathrm{N}, \mathrm{NO}_{3}{ }^{-}$, and $\mathrm{DOC}$ concentrations in the freshwater incubation chambers tended to be lower compared to brackish incubation chambers of the same salinity and $\mathrm{P}$ treatment levels. Whereas, $\mathrm{NO}_{2}{ }^{-}, \mathrm{NH}_{4}{ }^{+}$, and SRP concentrations in the freshwater incubation chambers tended to be higher compared to the brackish incubation chambers of the same salinity and $\mathrm{P}$ treatment levels.

For the final water samples collected on week 5, we performed a multiple regression analysis to look at changes in dissolved nutrients and $\mathrm{C}$ relative to gradients of salinity and $\mathrm{P}$. For the freshwater chambers, $\mathrm{N}+\mathrm{N}$ was negatively correlated with salinity and decreased $7.0 \mu \mathrm{g} \mathrm{L}^{-1}$ for every $1 \mathrm{ppt}$ increase in salinity $\left(P=0.03 ; \mathrm{R}^{2}=0.25\right)$; however, $\mathrm{P}$ treatment level had no effect $\left(P=0.17 ; \mathrm{R}^{2}=0.25\right)$. Freshwater $\mathrm{NH}_{4}{ }^{+}$multiple regression analysis was not significant for both salinity $\left(P=0.10 ; \mathrm{R}^{2}=0.17\right)$ and $\mathrm{P}(P=$ $\left.0.21 ; \mathrm{R}^{2}=0.17\right)$. Freshwater SRP was positively correlated with salinity and increased $1.6 \mu \mathrm{g} \mathrm{L} \mathrm{L}^{-1}$ for every $1 \mathrm{ppt}$ increase in salinity $\left(P<0.01 ; \mathrm{R}^{2}=0.75\right)$; however, $\mathrm{P}$ treatment level had no effect $\left(P=0.50 ; \mathrm{R}^{2}=0.75\right)$. Freshwater DOC was also positively correlated with salinity and increased $158 \mu \mathrm{g} \mathrm{L}{ }^{-1}$ for every 1 ppt increase in salinity $\left(P<0.01 ; \mathrm{R}^{2}=\right.$ 0.47); however, $\mathrm{P}$ treatment level had no effect $\left(P=0.98 ; \mathrm{R}^{2}=0.74\right)$. For the brackish chambers, $\mathrm{N}+\mathrm{N}$ was negatively correlated with salinity and decreased $8.0 \mu \mathrm{g} \mathrm{L} \mathrm{L}^{-1}$ for every 1 ppt increase in salinity $\left(P<0.01 ; \mathrm{R}^{2}=0.31\right)$; however, $\mathrm{P}$ treatment level had no effect $\left(P=0.24 ; \mathrm{R}^{2}=0.31\right)$. Brackish $\mathrm{NH}_{4}{ }^{+}$was negatively correlated with salinity and 
decreased $2.38 \mu \mathrm{g} \mathrm{L}^{-1}$ for every $1 \mathrm{ppt}$ increase in salinity $\left(P<0.01 ; \mathrm{R}^{2}=0.65\right)$; however, P treatment level had no effect $\left(P=0.67 ; \mathrm{R}^{2}=0.65\right)$. Brackish SRP was negatively correlated with salinity and decreased $0.09 \mu \mathrm{g} \mathrm{L}^{-1}$ for every $1 \mathrm{ppt}$ increase in salinity $(P<$ $\left.0.01 ; \mathrm{R}^{2}=0.79\right)$; however, $\mathrm{P}$ treatment level had no effect $\left(P=0.22 ; \mathrm{R}^{2}=0.79\right)$. Brackish DOC was also negatively correlated with salinity and decreased $69 \mu \mathrm{g} \mathrm{L}^{-1}$ for every $1 \mathrm{ppt}$ increase in salinity $\left(P<0.01 ; \mathrm{R}^{2}=0.69\right)$ and negatively correlated with $\mathrm{P}$ treatment level and decreased $5.6 \mu \mathrm{g} \mathrm{L}^{-1}$ for every $1 \mu \mathrm{g} \mathrm{L}^{-1}$ increase in $\mathrm{P}\left(P=0.02 ; \mathrm{R}^{2}=0.69\right)$.

\section{Soil elemental stoichiometry}

The average initial elemental composition of the freshwater soils collected for the experiment was $39.6 \pm 0.5 \% \mathrm{C}, 3.4 \pm 0.4 \% \mathrm{~N}$, and $0.03 \pm 0.00 \% \mathrm{P}$. The average initial elemental composition of the brackish soils collected for the experiment was $11.1 \pm 2.3$ $\% \mathrm{C}, 0.6 \pm 0.1 \% \mathrm{~N}$, and $0.01 \pm 0.00 \% \mathrm{P}$.

Best models of soil \% C included salt $\times$ soil type $\times$ week and salt $\times$ soil type, indicating that interactions between salinity, soil type, and time are essential to determining soil \%C whereas P treatment level is not (Table 2). Similarly, the best model for soil $\% \mathrm{~N}$ was salt $\times$ soil type $\times$ week $($ Table 2$)$. Best models of soil $\% \mathrm{P}$ were the same as for $\% \mathrm{C}$ and also included salt $\times \mathrm{P} \times$ soil type indicating that $\mathrm{P}$ treatment level also interacts with soil type, and salinity treatment to predict soil \%P (Table 2).

Best models predicting soil stoichiometry $(\mathrm{C}: \mathrm{N}, \mathrm{C}: \mathrm{P}$, and $\mathrm{N}: \mathrm{P})$ were similar to those predicting the individual elemental compositions of the soil. The best model for soil $\mathrm{C}: \mathrm{N}$ was soil type $\times \mathrm{P} \times$ week indicating that though salinity and its interaction with time and soil type were important in determining $\% \mathrm{C}$ and $\% \mathrm{~N}$, salinity is not as strong of a 
predictor for soil C:N (Table 2). Best models for predicting soil C:P included salt $\times$ soil type, salt + soil type, salt + soil type + week, and salt + P + soil type, indicating both additive and interactive effects of salinity, $\mathrm{P}$, soil type, and time influence C:P (Table 2). Best models of $\mathrm{N}: \mathrm{P}$ included salt $\times$ soil type and salt $\times$ soil type $\times$ week which indicates that despite $\mathrm{P}$ interacting with salt and soil type to predict $\% \mathrm{P}$ it is not as important as interactions between salinity, soil type, and time at predicting soil N:P (Table 2).

For the freshwater soil, the multiple linear regression analysis of soil \%C sampled at week 2 and 5, salinity and soil \%C were negatively correlated soil (Figure 2). At week 2 and 5 a 1 ppt increase in salinity decreased soil $\% \mathrm{C}$ by $0.36 \%(P<0.01)$ and by $0.39 \%$ $(P<0.01)$, respectively (Table 7). The multiple linear regression analysis of soil $\% \mathrm{~N}$ and $\% \mathrm{P}$ for freshwater soil were not significant (Table 7). For the brackish soil, the multiple linear regression analysis of soil \% C, \% N, and \% P were not significant (Figure 3).

Soil $\% \mathrm{C}, \% \mathrm{~N}$, and $\% \mathrm{P}$ were higher in the freshwater soils compared to the brackish soils at the same salinity and $\mathrm{P}$ treatment level. While $\mathrm{C}: \mathrm{N}$ was lower in the freshwater soils compared to the brackish soils at the same salinity and P treatment level. Soil C:P and $\mathrm{N}: \mathrm{P}$ were typically higher in the freshwater soils compared to brackish soils at the same salinity and P treatment level.

\section{Extracellular enzyme activities}

All EEAs were consistently higher in freshwater soils compared to brackish soils at the same salinity and P treatment level (Table S1). Phosphatase activity had the fewest best fitting models which were salt $\times$ soil type $\times$ week and salt $\times$ soil type providing evidence interactive effects of salinity, soil type, and time influence phosphatase enzyme 
potential (Table 3). Best models for leucine aminopeptidase activity included salt $\times \mathrm{P} \times$ week, soil type $\times$ week, salt $\times$ week, and salt $\times$ site $\times$ week $($ Table 3$)$. Best performing models for arylsulfatase and $\beta$-1,4-cellobiosidase were the same, though the ranking of each model was different for the two enzymes (Table 3). $\beta$-1,4-glucosidase had the highest number of best fitting models with 6 best-fit models which included both additive and interactive effects of salinity, $\mathrm{P}$, soil type, and time (Table 3).

Microbial EEAs from freshwater and brackish soils did not respond to any concentration of added P. For freshwater soils, only phosphatase activity responded to elevated salinity (Figure 4). For every 1 ppt increase in salinity, phosphatase activity decreased by $2.08 \mu \mathrm{mol} \mathrm{g} \mathrm{g}^{-1} \mathrm{~h}^{-1}(P<0.02)$. For brackish soil, only arylsulfatase activity responded to elevated salinity (Figure 5). For every 1 ppt increase in salinity, arylsulfatase activity increased by $0.04 \mu \mathrm{mol} \mathrm{g}^{-1} \mathrm{~h}^{-1}(P<0.01)$.

\section{Soil microbial respiration rates and biomass carbon}

Both soil microbial respiration rates and biomass $\mathrm{C}$ were consistently higher within freshwater than brackish soils at the same salinity and P treatment level. The best model for soil respiration rate was salt $\times$ soil type $\times$ week indicating that interactions of salinity, soil type, and time have more control on soil respiration than $\mathrm{P}$ (Table 4). Microbial respiration rates associated with incubated freshwater soils did not respond to added salinity after week 2 , but respiration rates declined after 5 weeks of exposure to elevated salinity concentrations (Figure 4). For every 1 ppt increase in salinity, there was a $0.013 \mathrm{mg} \mathrm{O}_{2} \mathrm{~g}^{-1} \mathrm{~h}^{-1}$ increase in respiration rates $(P=0.01$; Figure 4). For brackish soils, 
for every $1 \mu \mathrm{g} \mathrm{L}^{-1}$ increase in salinity, respiration rates increased by $4 \times 10^{-4} \mathrm{mg} \mathrm{O}_{2} \mathrm{~g}^{-1} \mathrm{~h}^{-1}$ after 2 weeks and $0.00007 \mathrm{mg} \mathrm{O}_{2} \mathrm{~g}^{-1} \mathrm{~h}^{-1}$ after 5 weeks $(P=0.01$; Figure 4$)$.

There were seven best performing models for predicting microbial biomass $\mathrm{C}$ that included both additive and interactive effects of salinity, $\mathrm{P}$, soil type, and time indicating that microbial biomass $\mathrm{C}$ is sensitive to changes in salinity and $\mathrm{P}$, different among soil types, and varies over time (Table 4). For freshwater soils, in the multiple linear regression analysis, added salinity concentrations did not affect microbial biomass $\mathrm{C}$ after 2 or 5 weeks of exposure (Figure $5 ; P>0.05$ ). For brackish soils, for every 1 ppt increase in added salinity concentration, microbial biomass $C$ increased by $67 \mu \mathrm{mol} \mathrm{C} \mathrm{L}{ }^{-1} \mathrm{~g}^{-1}$ after 2 weeks $(P<0.04)$ and $148 \mu \mathrm{mol} \mathrm{C} \mathrm{L} \mathrm{L}^{-1} \mathrm{~g}^{-1}$ after 5 weeks $(P=0.04$; Figure 5).

\section{DISCUSSION}

Sea-level rise and diversion of historical freshwater flow to the Everglades cooccur and exacerbate saltwater intrusion. Saltwater intrusion in the Everglades exposes soils to both salt stress and P subsidies causing changes in ecosystem function.

Additionally, legacies of saltwater intrusion are present within the Everglades gradient from freshwater to brackish marshes. We implemented a microcosm study to quantify direct effects of increased salinity and $\mathrm{P}$ on microbial processing in both freshwater and brackish soils from the Florida Everglades. We predicted that salinity would suppress EEAs, microbial biomass $\mathrm{C}$, and respiration rates and increasing $\mathrm{P}$ would enhance microbial EEAs, soil respiration, and microbial biomass C. We found that salinity suppressed P-acquiring enzymes in freshwater soil and enhanced S-acquiring enzymes in brackish soil while P had no direct effects any EEAs. We found that salinity suppressed 
soil respiration rates in freshwater soil and $\mathrm{P}$ expression of soil respiration rates in brackish soil. We predicted increased salinity would lower soil \%C and increased P would increase soil $\% \mathrm{P}$. We found the freshwater soil $\% \mathrm{C}$ to be more responsive to salinity additions compared to the brackish soils, indicating that $\mathrm{C}$ losses associated with increased salinity may have already altered the brackish soil used in our study. We discovered microbial functional responses and soil elemental composition were most sensitive to salinity while respiration rates and biomass $\mathrm{C}$ were more sensitive to $\mathrm{P}$. All response measures varied temporally and between freshwater and brackish soils. Salinity and $\mathrm{P}$ exposure alter the concentrations of dissolved nutrients and organic $\mathrm{C}$ within the surface waters of wetlands. The effects of salinity and $\mathrm{P}$ on water chemistry is dependent upon the duration of exposure and the soil type which can be a source of dissolved nutrients and $\mathrm{C}$ to the water column and consequentially be exported from the system. Water collected from the freshwater incubation chambers had higher NH4+, SRP, and DOC compared to water collected from the brackish incubation chambers. Within the freshwater incubation chambers, we identified a P concentration threshold at $20 \mu \mathrm{g} \mathrm{L}^{-1}$ when salinity was at 0 ppt. Phosphorus dissolved in the water column was not used by the microbial community until it had reached a threshold at $40 \mu \mathrm{g} \mathrm{L}^{-1}$. Salinity also immobilized microbial utilization of $\mathrm{P}$, and the highest salinity chambers had the highest dissolved P. In contrast, brackish chambers, microbial communities within the soil were potentially able to use added $\mathrm{P}$ and dissolved $\mathrm{P}$ within the water column was lower at higher salinities. Dissolved organic C showed similar trends as SRP specific to each soil type; DOC was lost to the water column as salinity increased in freshwater chambers and was removed from the water column in brackish chambers. Diminished C and P content 
found in the brackish soils may have prevented contributions of these constituents to the surface waters following salinity exposure. Our results suggest that water biogeochemistry of freshwater and brackish soil is fundamentally different in their response to salinity.

Exposure to increased salinity decreased soil \% $\mathrm{C}$ which has also been documented in other wetland types and saltwater intrusion simulations (Weston et al. 2011; Servais et al. in prep). Initial \%C content within our brackish soils was $3.5 \times$ lower than $\% \mathrm{C}$ of initial freshwater soil indicating that the brackish soil may have already experienced C loss from saltwater intrusion (Chambers 2013, Neubauer et al. 2013). The low soil \% $\mathrm{C}$ within the brackish soils indicates that $\mathrm{C}$ loss is a legacy of previous exposure to saltwater intrusion which influenced how the brackish soils in our study responded to salinity and $\mathrm{P}$ treatments. Since soil \%C was low, the brackish soil did not appear to be contributing $\mathrm{C}$ to the water column. Additionally, as we had predicted, the freshwater soil \% $\mathrm{C}$ was more responsive to the salinity gradient compared to brackish soils. Increases in salinity were negatively correlated with \%C in the freshwater soil. Previous studies suggest that exposure to elevated salinity can result in desorption of organic particles and lead to C export from soils (Liu and Lee 2007; Servais et al. in review). Other studies have shown that $\mathrm{C}$ inputs into the soil by plants are also inhibited by increases in salinity (Wilson et al. in review; Charles et al. in prep). The brackish soils collected for our experiment were taken from an area of the Everglades that displays symptoms of soil subsidence referred to as peat collapse (Wilson et al. in review; Servais et al. in prep). In the Everglades and other coastal wetlands, peat collapse is attributed to changing inundation level and saltwater intrusion (Wanless and Vlaswinkel 2005). Lower 
overall soil \%C within the brackish soils and the negative relationship between salinity and $\% \mathrm{C}$ within the freshwater soils indicates salinity as a driver of $\mathrm{C}$ losses from wetland soil experiencing saltwater intrusion.

Differences in EEAs were driven by differences between soil type and temporal variability in response to added salinity and $\mathrm{P}$ concentrations. In our study, there were two instances when EEAs were directly affected by treatment gradients within each soil type. In freshwater soils, phosphatase was negatively correlated with salinity increases. In brackish soils, arylsulfatase was positively associated with salinity increases. The observed effect of our salinity gradient on phosphatase (P-acquiring) and arylsulfatase (Sacquiring) indicates that freshwater soil P-acquiring enzymes respond more quickly (2 weeks) compared to brackish S-acquiring enzymes (5 weeks). Freshwater P-acquiring enzymes were suppressed while brackish sulfur-acquiring enzymes were enhanced with increased salinity. Freshwater soil phosphatase responses to salinity likely result from initial suppression of microbial community function because of osmotic stress (Kempf and Brenner 1998) combined with increased availability of $\mathrm{P}$ as it is desorbed from the soil (Flower et al. 2017). Although P-acquiring enzymes were reduced with elevated salinity in week 2 , microbes appear to acclimate by week 5 even though impacts on water chemistry persist. Enhanced sulfur-acquiring enzyme activities sulfate within higher salinity treatment levels and increased microbial utilization of available sulfur for sulfate reduction. Sulfate may act as a subsidy in brackish soils because it can be used as an alternative electron acceptor.

Microbial respiration rates associated with incubated freshwater soils were more sensitive to the stress of salinity, whereas respiration rates associated with brackish soil 
were most sensitive to subsidies of $\mathrm{P}$. There is no consensus in the literature about how salinity affects $\mathrm{C}$ mineralization (Herbert et al. 2015). Previous experiments in Everglades soils have shown no effect (Chambers et al. 2013), suppression of soil C mineralization (Chowdhury et al. 2011, Wilson et al. in prep), and increased rates of soil C mineralization (Chambers et al. 2011, Servais et al. in review). The positive relationship between $\mathrm{P}$ and brackish soil respiration rates was most robust at week 2 but remained significant at week 5 . Phosphorus addition to brackish soils likely stimulates the microbial use of dissolved $\mathrm{C}$ and which has also been correlated with increased arylsulfatase activity (Klose et al. 2011). Freshwater soil respiration rates were negatively correlated with salinity at week 5 indicating there may be a lag in freshwater soil response to salinity exposure which accumulated over time.

There were no direct effects of $\mathrm{P}$ addition on EEAs or soil elemental composition indicating that our addition of $\mathrm{P}$ did not alter microbial nutrient demand or nutrient availability. Freshwater wetlands found in the Florida Everglades and throughout the Caribbean are extremely limited by phosphorus $(\mathrm{P})$ and often receive most of the limiting nutrient from marine water inputs (Fourqurean et al. 1993; Boyer et al. 1999; Noe et al. 2001; Childers et al. 2006). When saltwater infiltrates the porous limestone bedrock of the Everglades, P adsorbed to calcium carbonate is released into the marsh (Price et al. 2006; Price et al. 2010; Flower et al. 2017). Therefore, we had expected strong responses to $\mathrm{P}$ addition. The highest concentration of SRP measured within incubation chambers on any sampling date was $58.3 \mu \mathrm{g} \mathrm{L}^{-1}$ (average was $18.0 \mu \mathrm{g} \mathrm{L} \mathrm{L}^{-1}$ ) which is higher than the threshold concentration for $\mathrm{P}$ of $12.0 \mu \mathrm{g} \mathrm{L}^{-1}$ recommended for the Everglades (Richardson et al. 2007). Even though our highest treatment level of $\mathrm{P}$ was $6.7 \times$ the 
prescribed threshold, we were able to detect those levels of P in the SRP measurements. Previous $\mathrm{P}$ enrichment studies in Everglades soils have shown $\mathrm{P}$ accumulation within the soil to take more than a year to be detectable (Servais et al. in review). Microbial utilization of $\mathrm{P}$ is likely constrained by anoxic conditions and salinity stress (Helton et al. 2015). However, it is important to mention that other ecosystem components within the Everglades, like periphyton and macrophytes, are sensitive to $\mathrm{P}$ which could lead to indirect effects on soil microbial functioning. We were interested in assessing the direct impact of salinity and $\mathrm{P}$ on soil biogeochemical cycles and therefore, constrained the experiment to only the soil. More work is necessary to determine how plant response across gradients of salinity and $\mathrm{P}$ will interact with the soil microbial compartment to affect ecosystem processes.

Salinity exposure leads to osmotic stress and can cause changes in microbial assemblages (Ikenaga et al. 2010) and the diversion of microbial resources from the production of extracellular enzymes to the creation of osmolytes (Killham 1994, Kempf and Bremer 1998) which is energy intensive (Oren 2001). Microbial biomass decreases with salinity (Malik and Azam 1980) and increases with P (Liu et al. 2012). Therefore, we predicted combinations of the low salinity and high $\mathrm{P}$ levels to result in the greatest increase in microbial biomass. However, there was no direct effect of $\mathrm{P}$ on microbial biomass $\mathrm{C}$ in either soil type. Our study found a positive relationship between microbial biomass $\mathrm{C}$ and salinity within the brackish soils which may have resulted from a faster adaption in microbial assemblages to higher salinity in these already exposed soils. Previous research suggests that some microbes within any soil can retain function and increase biomass despite high salinities (Yan and Marschner 2012). 
Even though increases in salinity enhanced some microbial functioning in the brackish soil, \%C, EEAs, microbial respiration rates, and microbial biomass $\mathrm{C}$ were consistently lower within the brackish soils compared to the freshwater soils. Therefore, we may expect suppressed microbial activity, respiration, microbial biomass $\mathrm{C}$ to be an indicator of wetland collapse following saltwater intrusion. Several studies have reported salinity suppresses EEAs (Jackson and Vallaire 2009, Neubauer et al. 2013, Servais et al. in review) and regulates microbial community metabolic processes (Garcia-Pinchel et al. 1999, Sørenson et al. 2004, Abed et al. 2007). Studies reporting increased enzyme activity had narrower salinity gradients (0 to $7 \mathrm{ppt}$; Morrissey et al. 2015) which is less than the difference in ambient salinity between our freshwater and brackish soils. Results from our experiment show that specific microbial functions, like the production of $\mathrm{C}$ - and $\mathrm{N}$-acquiring enzymes may be resistant within each soil type to changes in salinity and $\mathrm{P}$, while other functions like soil respiration, freshwater P-acquiring enzymes, and brackish S-acquiring enzymes are altered when exposed to salinity and P perturbations. Our results provide a better understanding of how microbial function changes with increased salinity and $\mathrm{P}$ however, more work is necessary to elucidate the relationship between observed functional changes and microbial community diversity. Understanding the mechanisms by which salinity stress and P subsidies influence microbially-mediated ecosystem function is essential for establishing ecologically relevant recommendations for Everglades restoration. Everglades restoration is faced with possible competing priorities for managing inland waters for nutrient criteria relative to managing coastal waters for saltwater intrusion. 


\section{ACKNOWLEDGMENTS}

We thank G. Cabral and D. Segrera for laboratory assistance. Funding for this research was provided by the National Science Foundation award (DBI-1237517) to the Florida Coastal Everglades Long-Term Ecological Research (FCE LTER) Program. S. Servais was supported by research assistantship from Florida Sea Grant R/C-S-56 and Florida International University's Dissertation Year Fellowship. K. Morales and M. Fernandez were supported by the National Science Foundation's Research Experience for Undergraduates. This is contribution XX of the Southeast Environmental Research Center.

\section{LITERATURE CITED}

Abed, R. M., K. Kohls, and D. De Beer. 2007. Effect of salinity changes on the bacterial diversity, photosynthesis and oxygen consumption of cyanobacterial mats from an intertidal flat of the Arabian Gulf. Environmental Microbiology 9:1384-1392.

Boyer, J. N., J. W. Fourqurean, and R. D. Jones. 1999. Seasonal and long-term trends in the water quality of Florida Bay (1989-1997). Estuaries 22:417-430.

Childers, D. L., J. N. Boyer, S. E. Davis, C. J. Madden, D. T. Rudnick, and F. H. Sklar. 2006. Relating precipitation and water management to nutrient concentrations in the oligotrophic "upside-down" estuaries of the Florida Everglades. Limnology and Oceanography 51:602-616.

Chambers, L. G., T. Z. Osborne, and K. R. Reddy. 2013. Effect of salinity-altering pulsing events on soil organic carbon loss along an intertidal wetland gradient: a laboratory experiment. Biogeochemistry 115:363-383.

Chowdhury, N., P. Marschner, and R. Burns. 2011. Response of microbial activity and community structure to decreasing soil osmotic and matric potential. Plant and Soil 344:241-254.

Dick, R. P. 1994. Soil Enzyme Activities as Indicators of Soil Quality1. Defining soil quality for a sustainable environment, Defining Soil Quality 107-124. 
Edmonds, J. W., N. B. Weston, S. B. Joye, X. Mou, and M. A. Moran. 2009. Microbial community response to seawater amendment in low-salinity tidal sediments. Microbial Ecology 58:558-568.

Flower, H., M. Rains, D. Lewis, J. Z. Zhang, and R. Price. 2017. Saltwater intrusion as potential driver of phosphorus release from limestone bedrock in a coastal aquifer. Estuarine, Coastal and Shelf Science 184:166-176.

Fourqurean, J. W., R. D. Jones, and J. C. Zieman. 1993. Process influencing water column nutrient characteristics and phosphorus limitation of phytoplankton biomass in Florida Bay, FL, USA: inferences from spatial distributions. Estuarine, Coastal and Shelf Science 36:295-314.

Franklin, J. F., D. Lindenmayer, J. A. MacMahon, A. McKee, J. Magnuson, D. A. Perry, R. Waide, and D. Foster. 2000. Threads of continuity. Conservation 1:8-17.

Freeman, C., G. Liska, N. J. Ostle, M. A. Lock, B. Reynolds, and J. Hudson. 1996. Microbial activity and enzymic decomposition processes following peatland water table drawdown. Plant and Soil 180:121-127.

Garcia-Pichel, F., M. Kühl, U. Nübel, and G. Muyzer. 1999. Salinity-dependent limitation of photosynthesis and oxygen exchange in microbial mats. Journal of Phycology 35:227-238.

Green, A. J., P. Alcorlo, E. T. Peeters, E. P. Morris, J. L. Espinar, M. A. Bravo-Utrera, J. Bustamante, R. Díaz-Delgado, A. A. Koelmans, R. Mateo, and W. M. Mooij. 2017. Creating a safe operating space for wetlands in a changing climate. Frontiers in Ecology and the Environment 15:99-107.

Hart, E. A., and R. J. Lovvorn. 2003. Algal vs. macrophyte inputs to food webs of inland saline wetlands. Ecology 84:3317-3326.

Herbert, E. R., P. Boon, A. J. Burgin, S. C. Neubauer, R. B. Franklin, M. Ardón, K. N. Hopfensperger, L. P. Lamers, and P. Gell. 2015. A global perspective on wetland salinization: ecological consequences of a growing threat to freshwater wetlands. Ecosphere 6:1-43.

Hobbie, J. E. 1988. A comparison of the ecology of planktonic bacteria in fresh and salt water. Limnology and Oceanography 33:750-764.

Holling, C. S. 1973. Resilience and stability of ecological systems. Annual Review of Ecology and Systematics, 4:1-23.

Ikenaga, M., R. Guevara, A. L. Dean, C. Pisani, and J. N. Boyer. 2010. Changes in community structure of sediment bacteria along the Florida coastal Everglades marsh-mangrove-seagrass salinity gradient. Microbial Ecology 59:284-295.

Jackson, C. R. and S. C. Vallaire. 2009. Effects of salinity and nutrients on microbial assemblages in Louisiana wetland sediments. Wetlands 29:277-287. 
Johnstone, J. F., C. D. Allen, J. F. Franklin, L. E. Frelich, B. J. Harvey, P. E. Higuera, M. C. Mack, R. K. Meentemeyer, M. R. Metz, G. L. Perry, and T. Schoennagel. 2016. Changing disturbance regimes, ecological memory, and forest resilience. Frontiers in Ecology and the Environment 14:369-378.

Kempf, B., and E. Bremer. 1998. Uptake and synthesis of compatible solutes as microbial stress responses to high-osmolality environments. Archives of Microbiology 170:319-330.

Killham, K., 1994. Soil ecology. Cambridge University Press. Cambridge, UK.

Klose, S., S. Bilen, M. A. Tabatabai, W. A. Dick, and R. P. Dick. 2011. Sulfur cycle enzymes. Methods of soil enzymology. Soil Science Society of America, Wisconsin, USA.

Liu, L., P. Gundersen, T. Zhang, and J. Mo. 2012. Effects of phosphorus addition on soil microbial biomass and community composition in three forest types in tropical China. Soil Biology and Biochemistry 44:31-38.

Malik, K. A., and F. Azam. 1980. Effect of salinity on ${ }^{14}$ C-labelled microbial biomass and its contribution to soil organic matter. Pakistan Journal of Botany 12:117-127.

Morrison, E., S. Newman, H. S. Bae, Z. He, J. Zhou, K. R. Reddy, and A. Ogram. 2016. Microbial genetic and enzymatic responses to an anthropogenic phosphorus gradient within a subtropical peatland. Geoderma 268:119-127.

Morrissey, E. M., J. L. Gillespie, J. C. Morina, and R. B. Franklin. 2014. Salinity affects microbial activity and soil organic matter content in tidal wetlands. Global Change Biology 20:1351-1362.

Nelson, T. M., C. Streten, K. S. Gibb, and A. A. Chariton. 2015. Saltwater intrusion history shapes the response of bacterial communities upon rehydration. Science of the Total Environment 502:143-148.

Noe, G. B., D. L. Childers, and R. D. Jones. 2001. Phosphorus biogeochemistry and the impact of phosphorus enrichment: Why is the Everglades so unique? Ecosystems 4:603-624.

Odum, E. P., J. T. Finn, and E. H. Franz. 1979. Perturbation theory and the subsidy-stress gradient. Bioscience 29:349-352.

Oren, A. 2001. The bioenergetic basis for the decrease in metabolic diversity at increasing salt concentrations: implications for the functioning of salt lake ecosystems. Hydrobiologia 466:61-72.

Padisak, J. 1992. Seasonal Succession of Phytoplankton in a Large Shallow Lake (Balaton, Hungary)--A Dynamic Approach to Ecological Memory, Its Possible Role and Mechanisms. Journal of Ecology 217-230. 
Price, R. M., P. K. Swart, and J. W. Fourqurean. 2006. Coastal groundwater discharge-an additional source of phosphorus for the oligotrophic wetlands of the Everglades. Hydrobiologia 569:23-36.

Price, R. M., M. R. Savabi, J. L. Jolicoeur, and S. Roy. 2010. Adsorption and desorption of phosphate on limestone in experiments simulating seawater intrusion. Applied Geochemistry 25:1085-1091.

Scheffer, M., S. Carpenter, J. A. Foley, C. Folke, and B. Walker. 2001. Catastrophic shifts in ecosystems. Nature 413:591.

Trumbore, S., P. Brando, and H. Hartmann. 2015. Forest health and global change. Science 349:814-818.

Turner, M. G. 2010. Disturbance and landscape dynamics in a changing world. Ecology 91:2833-2849.

Wanless, H. R., and B. Vlaswinkel. 2005. Coastal landscape and channel evolution affecting critical habitats at Cape Sable, Everglades National Park, Florida. Final Report to Everglades National Park, United States Department of the Interior, Homestead, FL, USA.

White, P. S., and A. Jentsch. 2001. The search for generality in studies of disturbance and ecosystem dynamics. In Progress in Botany (pp. 399-450). Springer, Berlin, Heidelberg.

Wright, A. L., and K. R. Reddy. 2001. Phosphorus loading effects on extracellular enzyme activity in Everglades wetland soils. Soil Science Society of America Journal 65:588-595.

Yan, N., and P. Marschner. 2012. Response of microbial activity and biomass to increasing salinity depends on the final salinity, not the original salinity. Soil Biology and Biochemistry 53:50-55. 
TABLE 1. Linear fixed-effects models and model weights comparing saltwater (salt), phosphorus (P), week, and soil type and their interactions with dissolved constituents within the water of the incubation chambers. Models with $\Delta \mathrm{AIC}_{\mathrm{c}} \leq 2$ are considered equivalent.

\begin{tabular}{|c|c|c|c|c|c|c|}
\hline & Model & $K$ & $\Delta \mathrm{AIC}_{\mathrm{c}}$ & $\mathrm{AIC}_{\mathrm{c}} \mathrm{wt}$ & $\begin{array}{c}\text { Cum } \\
\text { wt }\end{array}$ & $\begin{array}{c}\log \\
\text { likelihood }\end{array}$ \\
\hline \multicolumn{7}{|l|}{$N+N$} \\
\hline & salt $+\mathrm{P}+$ soil type + week & 6 & 0.00 & 0.40 & 0.40 & -728.04 \\
\hline & salt + soil type + week & 5 & 0.49 & 0.71 & 0.71 & -729.35 \\
\hline \multicolumn{7}{|l|}{$\mathrm{NO}_{3}^{-}$} \\
\hline & salt $\times$ soil type $\times$ week & 9 & 0.00 & 1.00 & 1.00 & -634.17 \\
\hline \multicolumn{7}{|l|}{$\mathrm{NO}_{2}^{-}$} \\
\hline & salt $\times$ soil type $\times$ week & 9 & 0.00 & 1.00 & 1.00 & -651.22 \\
\hline \multicolumn{7}{|c|}{$\mathrm{NH}_{4}^{+}$} \\
\hline & salt $\times \mathrm{P} \times$ soil type $\times$ week & 17 & 0.00 & 0.99 & 0.99 & -938.25 \\
\hline \multicolumn{7}{|l|}{$S R P$} \\
\hline & salt $\times$ soil type & 5 & 0.00 & 0.50 & 0.50 & -94.99 \\
\hline & salt $\times \mathrm{P} \times$ soil type & 9 & 0.42 & 0.40 & 0.90 & -90.89 \\
\hline \multicolumn{7}{|l|}{$D O C$} \\
\hline & salt $\times$ soil type $\times$ week & 9 & 0.00 & 0.99 & 0.99 & -1307.63 \\
\hline
\end{tabular}


TABLE 2. Linear fixed-effects models and model weights comparing saltwater (salt), phosphorus (P), week, and soil type and their interactions on soil elemental

composition and stoichiometry. Models with $\triangle \mathrm{AIC}_{\mathrm{c}} \leq 2$ are considered equivalent.

\begin{tabular}{|c|c|c|c|c|c|c|}
\hline & Model & $K$ & $\Delta \mathrm{AIC}_{\mathrm{c}}$ & $\mathrm{AIC}_{\mathrm{c}} \mathrm{wt}$ & $\begin{array}{c}\text { Cum } \\
\text { wt }\end{array}$ & $\begin{array}{c}\log \\
\text { likelihood }\end{array}$ \\
\hline \multicolumn{7}{|l|}{$\% C$} \\
\hline & salt $\times$ soil type $\times$ week & 9 & 0.00 & 0.71 & 0.71 & -565.77 \\
\hline \multicolumn{7}{|l|}{$\% N$} \\
\hline & salt $\times$ soil type $\times$ week & 9 & 0.00 & 0.98 & 0.98 & 4.43 \\
\hline \multicolumn{7}{|l|}{$\% P$} \\
\hline & salt $\times$ soil type $\times$ week & 9 & 0.00 & 0.62 & 0.62 & 741.08 \\
\hline & salt $\times$ soil type & 5 & 1.63 & 0.27 & 0.89 & 735.94 \\
\hline \multicolumn{7}{|l|}{$C: N$} \\
\hline & soil type $\times \mathrm{P} \times$ week & 9 & 0.00 & 0.88 & 0.88 & -774.80 \\
\hline \multicolumn{7}{|l|}{$C: P$} \\
\hline & salt $\times$ soil type & 5 & 0.00 & 0.46 & 0.46 & -1465.89 \\
\hline & salt + soil type & 4 & 1.30 & 0.24 & 0.71 & -1467.60 \\
\hline \multicolumn{7}{|l|}{$N: P$} \\
\hline & salt $\times$ soil type & 5 & 0.00 & 0.67 & 0.67 & -912.15 \\
\hline
\end{tabular}


TABLE 3. Linear fixed-effects models and model weights comparing saltwater (salt), phosphorus $(\mathrm{P})$, week, and soil type and their interactions with extracellular enzymes. Models with $\triangle \mathrm{AIC}_{\mathrm{c}} \leq 2$ are considered equivalent.

Model $K \quad \Delta \mathrm{AIC}_{\mathrm{c}}$

phosphatase

salt $\times$ soil type $\times$ week

arylsulfatase

soil type

salt + soil type

soil type $\times$ week

$\beta$-1,4-glucosidase

soil type

salt $+\mathrm{P}+$ soil type

$\mathrm{P} \times$ soil type $\times$ week

salt $+\mathrm{P}+$ week

salt + soil type

salt $\times$ soil type

$\beta$-1,4-cellobiosidase

soil type

soil type $\times$ week

leucine aminopeptidase

salt $\times \mathrm{P} \times$ week

soil type $\times$ week

salt $\times$ week
$9-0.00$

$3 \quad 0.00$

$4 \quad 0.94$

$5 \quad 1.81$

$\mathrm{AIC}_{\mathrm{c}} \mathrm{wt}$

Cum wt

$\log$

likelihood

$3 \quad 0.00$

$5 \quad 0.54$

$9 \quad 0.81$

$5 \quad 1.00$

$4 \quad 1.09$

$5 \quad 1.88$

0.77

0.77

$-395.37$

$3 \quad 0.00$

$5 \quad 1.06$

0.31

0.20

0.31

0.51

$-284.42$

0.10

0.64

$-283.81$

$-283.13$

0.18

0.14

0.18

$-337.62$

0.32

$-335.69$

0.12

0.43

$-331.13$

0.11

0.54

$-335.92$

0.10

0.65

$-337.08$

0.07

0.72

$-336.37$

$9 \quad 0.00$

0.32

0.19

0.3

0.51

$-43.70$

$-42.04$

$5 \quad 1.47$

0.42

0.20

0.42

0.62

$-27.18$

5

1.57

0.19

0.80

$-32.59$

$-32.65$ 
TABLE 4. Linear fixed-effects models and model weights comparing saltwater (salt), phosphorus (P), week, and soil type and their interactions on microbial biomass carbon and soil respiration rate. Models with $\Delta \mathrm{AIC}_{\mathrm{c}} \leq 2$ are considered equivalent.

$\begin{array}{llllll}\text { Model } & K & \Delta \mathrm{AIC}_{\mathrm{c}} & \mathrm{AIC}_{\mathrm{c}} \mathrm{wt} & \mathrm{Cum} w \mathrm{log}\end{array}$

microbial biomass carbon

$\begin{array}{llllll}\text { salt + P + soil type + week } & 6 & 0.00 & 0.19 & 0.19 & -906.66 \\ \text { P + soil type + week } & 5 & 0.08 & 0.18 & 0.37 & -907.83 \\ \text { salt + P + soil type } & 5 & 0.18 & 0.17 & 0.54 & -907.88 \\ \text { salt + soil type + week } & 5 & 1.11 & 0.11 & 0.65 & -908.35 \\ \text { salt + soil type } & 4 & 1.26 & 0.10 & 0.75 & -909.53 \\ \text { soil type } & 3 & 1.30 & 0.10 & 0.85 & -910.64 \\ \text { salt } \times \text { soil type } & 5 & 1.70 & 0.08 & 0.93 & -908.64\end{array}$

soil respiration rate salt $\times$ soil type $\times$ week

$9 \quad 0.00$

0.99

0.99

147.16 
TABLE 5. Dissolved water constituents sampled from the freshwater soil incubation chambers after five weeks at different levels of added salinity (salt) and phosphorus (P) concentrations (subscripted numbers corresponded to ppt added salinity and $\mu \mathrm{g}$ $\mathrm{L}^{-1}$ added $\left.\mathrm{P}\right)$. Dissolved inorganic nitrogen $(\mathrm{N}+\mathrm{N})$, ammonium $\left(\mathrm{NH}_{4}{ }^{+}\right)$, soluble reactive $\mathrm{P}$ (SRP), and dissolved organic carbon (DOC) are reported in $\mu \mathrm{g} \mathrm{L}^{-1}$.

\begin{tabular}{|c|c|c|c|c|c|c|c|c|}
\hline \multirow[b]{2}{*}{ treatment } & \multicolumn{2}{|c|}{$\mathrm{N}+\mathrm{N}$} & \multicolumn{2}{|c|}{$\mathrm{NH}_{4}{ }^{+}-\mathrm{N}$} & \multicolumn{2}{|c|}{ SRP-P } & \multicolumn{2}{|c|}{ DOC } \\
\hline & $\mu \mathrm{g} \overline{\mathrm{L}^{-1}}$ & $\% \Delta$ & $\mu \mathrm{g} \mathrm{L}^{-1}$ & $\% \Delta$ & $\mu \mathrm{g} \mathrm{L}^{-1}$ & $\% \Delta$ & $\mu \mathrm{g} \mathrm{L}^{-1}$ & $\% \Delta$ \\
\hline control & 266 & & 43 & & 8 & & 11850 & \\
\hline salt $_{0} \mathrm{P}_{20}$ & 594 & 123 & 148 & 242 & 9 & 11 & 12790 & 8 \\
\hline salt $_{0} \mathrm{P}_{40}$ & 314 & 18 & 27 & -39 & 6 & -27 & 11630 & -2 \\
\hline salt $_{0} \mathrm{P}_{60}$ & 332 & 25 & 21 & -52 & 7 & -13 & 11510 & -3 \\
\hline saltt $_{0} \mathrm{P}_{80}$ & 256 & -4 & 18 & -58 & 7 & -21 & 11390 & -4 \\
\hline salt $_{4} \mathrm{P}_{0}$ & 202 & -24 & 39 & -10 & 11 & 36 & 13670 & 15 \\
\hline salt $_{4} \mathrm{P}_{20}$ & 305 & 15 & 64 & 48 & 18 & 112 & 12930 & 9 \\
\hline salt $_{4} \mathrm{P}_{40}$ & 202 & -24 & 48 & 10 & 17 & 98 & 13530 & 14 \\
\hline salt $_{4} \mathrm{P}_{60}$ & 252 & -5 & 63 & 45 & 12 & 39 & 12880 & 9 \\
\hline salt $_{4} \mathrm{P}_{80}$ & 202 & -24 & 34 & -23 & 12 & 45 & 12420 & 5 \\
\hline salt $_{7} \mathrm{P}_{0}$ & 210 & -21 & 74 & 71 & 11 & 38 & 13290 & 12 \\
\hline salt $_{7} \mathrm{P}_{20}$ & 242 & -9 & 101 & 132 & 22 & 164 & 13830 & 17 \\
\hline salt $_{7} \mathrm{P}_{40}$ & 272 & 2 & 87 & 100 & 17 & 102 & 13580 & 15 \\
\hline salt $_{7} \mathrm{P}_{60}$ & 178 & -33 & 49 & 13 & 15 & 75 & 12610 & 6 \\
\hline salt $_{7} \mathrm{P}_{80}$ & 242 & -9 & 45 & 3 & 12 & 49 & 13530 & 14 \\
\hline saltt $_{12} \mathrm{P}_{0}$ & 260 & -2 & 73 & 68 & 15 & 82 & 13650 & 15 \\
\hline salt $_{12} \mathrm{P}_{20}$ & 196 & -26 & 66 & 52 & 23 & 174 & 14020 & 18 \\
\hline salt $_{12} \mathrm{P}_{40}$ & 94 & -65 & 52 & 19 & 19 & 125 & 13510 & 14 \\
\hline salt $_{12} \mathrm{P}_{60}$ & 245 & -8 & 67 & 55 & 15 & 80 & 14080 & 19 \\
\hline salt $_{12} \mathrm{P}_{80}$ & 119 & -55 & 63 & 45 & 14 & 65 & 14900 & 26 \\
\hline salt $_{16} \mathrm{P}_{0}$ & 262 & -2 & 53 & 23 & 33 & 296 & 14980 & 26 \\
\hline salt $_{16} \mathrm{P}_{20}$ & 337 & 27 & 351 & 710 & 33 & 297 & 18220 & 54 \\
\hline salt $_{16} \mathrm{P}_{40}$ & 154 & -42 & 45 & 3 & 40 & 379 & 14980 & 26 \\
\hline salt $_{16} \mathrm{P}_{60}$ & 287 & 8 & 63 & 45 & 31 & 272 & 17360 & 47 \\
\hline salt $_{16} \mathrm{P}_{80}$ & 129 & -52 & 78 & 81 & 35 & 319 & 16970 & 43 \\
\hline
\end{tabular}


TABLE 6. Dissolved water constituents sampled from the brackish soil incubation chambers after five weeks at different levels of added salinity (salt) and phosphorus (P) concentrations (subscripted numbers corresponded to ppt added salinity and $\mu \mathrm{g}$ $\mathrm{L}^{-1}$ added $\left.\mathrm{P}\right)$. Dissolved inorganic nitrogen $(\mathrm{N}+\mathrm{N})$, ammonium $\left(\mathrm{NH}_{4}{ }^{+}\right)$, soluble reactive $\mathrm{P}$ (SRP), and dissolved organic carbon (DOC) are reported in $\mu \mathrm{g} \mathrm{L}^{-1}$.

\begin{tabular}{|c|c|c|c|c|c|c|c|c|}
\hline \multirow[b]{2}{*}{ treatment } & \multicolumn{2}{|c|}{$\mathrm{N}+\mathrm{N}$} & \multicolumn{2}{|c|}{$\mathrm{NH}_{4}{ }^{+}-\mathrm{N}$} & \multicolumn{2}{|c|}{ SRP-P } & \multicolumn{2}{|c|}{ DOC-C } \\
\hline & $\mu g \mathrm{~L}^{-1}$ & $\% \Delta$ & $\mu{\mathrm{g} \mathrm{\textrm {L } ^ { - 1 }}}^{-1}$ & $\% \Delta$ & $\mu \mathrm{g} \mathrm{\textrm {L } ^ { - 1 }}$ & $\% \Delta$ & $\mu \mathrm{g} \overline{\mathrm{L}^{-1}}$ & $\% \Delta$ \\
\hline control & 532 & & 54 & & 2.17 & & 12410 & \\
\hline salt $_{0} \mathbf{P}_{20}$ & 256 & -52 & 34 & -38 & 2.17 & 0 & 12270 & -1 \\
\hline salt $_{0} \mathrm{P}_{40}$ & 178 & -67 & 67 & 24 & 2.17 & 0 & 12220 & -2 \\
\hline salt $_{0} \mathrm{P}_{60}$ & 306 & -42 & 58 & 7 & 1.55 & -29 & 12010 & -3 \\
\hline salt $_{0} \mathrm{P}_{80}$ & 337 & -37 & 52 & -4 & 2.17 & 0 & 11780 & -5 \\
\hline salt $_{4} \mathrm{P}_{0}$ & 247 & -53 & 59 & 9 & 1.55 & -29 & 11640 & -6 \\
\hline salt $_{4} \mathrm{P}_{20}$ & 211 & -60 & 40 & -27 & 1.86 & -18 & 11420 & -8 \\
\hline salt $_{4} \mathrm{P}_{40}$ & 178 & -67 & 41 & -24 & 1.86 & -19 & 10920 & -12 \\
\hline salt $_{4} \mathrm{P}_{60}$ & 293 & -45 & 54 & 0 & 0.93 & -58 & 11370 & -8 \\
\hline salt $_{4} \mathrm{P}_{80}$ & 206 & -61 & 43 & -20 & 1.86 & -22 & 11230 & -10 \\
\hline salt $_{7} \mathrm{P}_{0}$ & 293 & -45 & 30 & -44 & 1.55 & -29 & 12010 & -3 \\
\hline salt $_{7} \mathrm{P}_{20}$ & 228 & -57 & 25 & -53 & 1.24 & -50 & 11220 & -10 \\
\hline salt $_{7} \mathrm{P}_{40}$ & 205 & -61 & 26 & -51 & 1.24 & -45 & 11070 & -11 \\
\hline salt $_{7} \mathrm{P}_{60}$ & 245 & -54 & 28 & -49 & 0.93 & -59 & 10810 & -13 \\
\hline salt $_{7} \mathrm{P}_{80}$ & 203 & -62 & 31 & -42 & 1.24 & -44 & 11280 & -9 \\
\hline salt $_{12} \mathrm{P}_{0}$ & 245 & -54 & 22 & -60 & 0.93 & -55 & 11100 & -11 \\
\hline salt $_{12} \mathrm{P}_{20}$ & 254 & -52 & 28 & -49 & 0.93 & -65 & 10860 & -12 \\
\hline salt $_{12} \mathrm{P}_{40}$ & 162 & -70 & 17 & -69 & 0.31 & -86 & 10990 & -11 \\
\hline salt $_{12} \mathrm{P}_{60}$ & 181 & -66 & 24 & -56 & 0.62 & -79 & 10560 & -15 \\
\hline salt $_{12} \mathrm{P}_{80}$ & 224 & -58 & 40 & -27 & 0.93 & -60 & 11070 & -11 \\
\hline salt $_{16} \mathrm{P}_{0}$ & 184 & -65 & 23 & -58 & 0.93 & -58 & 11120 & -10 \\
\hline salt $_{16} \mathrm{P}_{20}$ & 190 & -64 & 25 & -53 & 0.31 & -86 & 11050 & -11 \\
\hline salt $_{16} \mathrm{P}_{40}$ & 194 & -63 & 22 & -60 & 0.31 & -86 & 10960 & -12 \\
\hline salt $_{16} \mathrm{P}_{60}$ & 167 & -69 & 22 & -60 & 0.31 & -86 & 10890 & -12 \\
\hline salt $_{16} \mathrm{P}_{80}$ & 220 & -59 & 22 & -60 & 0.93 & -62 & 10710 & -14 \\
\hline
\end{tabular}

Notes: Data are not replicated $(n=1)$. The percent difference between control and treatment litter $\mathrm{C}: \mathrm{N}$ and $\mathrm{C}: \mathrm{P}$ molar ratios is shown as $\% \Delta$. 
TABLE 7. Elemental composition and stoichiometry of freshwater soils after five weeks at different treatment levels of added salinity (salt) and phosphorus $(\mathrm{P})$ concentrations (subscripted numbers corresponded to ppt added salinity and $\mu \mathrm{g} \mathrm{L}^{-1}$ added $\mathrm{P}$ ).

\begin{tabular}{|c|c|c|c|c|c|c|c|c|c|}
\hline \multirow[b]{2}{*}{ treatment } & \multirow[b]{2}{*}{$\% \mathrm{C}$} & \multirow[b]{2}{*}{$\% \mathrm{~N}$} & \multirow[b]{2}{*}{$\% \mathrm{P}$} & \multicolumn{2}{|c|}{ C:N } & \multicolumn{2}{|l|}{ C:P } & \multicolumn{2}{|c|}{$\mathrm{N}: \mathrm{P}$} \\
\hline & & & & ratio & $\% \Delta$ & ratio & $\% \Delta$ & ratio & $\% \Delta$ \\
\hline control & 40.8 & 2.48 & 0.03 & 19.2 & - & 3471.8 & - & 180.6 & - \\
\hline salt $_{0} \mathbf{P}_{20}$ & 34.4 & 2.54 & 0.02 & 15.8 & -18 & 4000.0 & 15 & 253.2 & 40 \\
\hline salt $_{0} \mathrm{P}_{40}$ & 41.1 & 3.00 & 0.03 & 16.0 & -17 & 3145.8 & -9 & 197.0 & 9 \\
\hline salt $_{0} \mathrm{P}_{60}$ & 41.4 & 2.32 & 0.04 & 20.8 & 8 & 2958.8 & -15 & 142.5 & -21 \\
\hline salt $_{0} \mathrm{P}_{80}$ & 41.1 & 1.88 & 0.02 & 25.5 & 33 & 4424.6 & 27 & 173.4 & -4 \\
\hline salt $_{4} \mathrm{P}_{0}$ & 32.4 & 2.20 & 0.01 & 17.2 & -11 & 5624.5 & 62 & 327.8 & 81 \\
\hline salt $_{4} \mathrm{P}_{20}$ & 35.2 & 2.12 & 0.02 & 19.4 & 1 & 3956.0 & 14 & 203.9 & 13 \\
\hline salt $_{4} \mathrm{P}_{40}$ & 38.3 & 2.15 & 0.03 & 20.8 & 8 & 3260.1 & -6 & 156.9 & -13 \\
\hline salt $_{4} \mathrm{P}_{60}$ & 38.8 & 2.51 & 0.02 & 18.0 & -6 & 4642.5 & 34 & 257.6 & 43 \\
\hline salt $_{4} \mathrm{P}_{80}$ & 39.3 & 2.31 & 0.03 & 19.9 & 3 & 3629.9 & 5 & 182.5 & 1 \\
\hline salt $_{7} \mathrm{P}_{0}$ & 34.7 & 2.32 & 0.02 & 17.4 & -9 & 4280.6 & 23 & 245.8 & 36 \\
\hline salt $_{7} \mathrm{P}_{20}$ & 36.8 & 2.50 & 0.02 & 17.2 & -11 & 3938.8 & 13 & 229.4 & 27 \\
\hline salt $_{7} \mathrm{P}_{40}$ & 37.1 & 2.45 & 0.02 & 17.7 & -8 & 4714.0 & 36 & 266.4 & 47 \\
\hline salt $_{7} \mathrm{P}_{60}$ & 39.2 & 2.67 & 0.03 & 17.1 & -11 & 3489.6 & 1 & 203.5 & 13 \\
\hline salt $_{7} \mathrm{P}_{80}$ & 37.5 & 2.41 & 0.03 & 18.2 & -5 & 3782.7 & 9 & 208.0 & 15 \\
\hline salt $_{12} \mathrm{P}_{0}$ & 34.9 & 2.38 & 0.02 & 17.1 & -11 & 4566.5 & 32 & 267.0 & 48 \\
\hline salt $_{12} \mathrm{P}_{20}$ & 34.2 & 1.97 & 0.02 & 20.3 & 6 & 3757.0 & 8 & 185.2 & 3 \\
\hline salt $_{12} \mathrm{P}_{40}$ & 32.3 & 2.07 & 0.02 & 18.2 & -5 & 4102.6 & 18 & 225.3 & 25 \\
\hline salt $_{12} \mathrm{P}_{60}$ & 32.6 & 1.83 & 0.01 & 20.8 & 8 & 6199.7 & 79 & 298.2 & 65 \\
\hline salt $_{12} \mathrm{P}_{80}$ & 36.8 & 2.20 & 0.02 & 19.5 & 1 & 4714.6 & 36 & 241.9 & 34 \\
\hline salt $_{16} \mathrm{P}_{0}$ & 35.0 & 2.47 & 0.02 & 16.6 & -14 & 4192.1 & 21 & 252.8 & 40 \\
\hline salt $_{16} \mathrm{P}_{20}$ & 25.9 & 1.86 & 0.01 & 16.3 & -15 & 6119.7 & 76 & 376.2 & 108 \\
\hline salt $_{16} \mathrm{P}_{40}$ & 37.3 & 2.46 & 0.02 & 17.7 & -8 & 5364.1 & 55 & 303.4 & 68 \\
\hline salt $_{16} \mathrm{P}_{60}$ & 35.4 & 1.88 & 0.02 & 22.0 & 15 & 3823.3 & 10 & 173.7 & -4 \\
\hline salt $_{16} \mathrm{P}_{80}$ & 33.1 & 2.24 & 0.02 & 17.2 & -10 & 3694.7 & 6 & 214.7 & 19 \\
\hline
\end{tabular}

Notes: Data are not replicated $(n=1)$. The percent difference between control and treatment litter $\mathrm{C}: \mathrm{N}$ and $\mathrm{C}: \mathrm{P}$ molar ratios is shown as $\% \Delta$. 
TABLE 8. Elemental composition and stoichiometry of brackish soils after five weeks at different treatment levels of added salinity (salt) and phosphorus (P) concentrations (subscripted numbers corresponded to ppt added salinity and $\mu \mathrm{g} \mathrm{L}^{-1}$ added $\mathrm{P}$ ).

\begin{tabular}{|c|c|c|c|c|c|c|c|c|c|}
\hline \multirow[b]{2}{*}{ treatment } & \multirow[b]{2}{*}{$\% \mathrm{C}$} & \multirow[b]{2}{*}{$\% \mathrm{~N}$} & \multirow[b]{2}{*}{$\% \mathrm{P}$} & \multicolumn{2}{|c|}{$\underline{C: N}$} & \multicolumn{2}{|l|}{ C:P } & \multicolumn{2}{|c|}{$\mathrm{N}: \mathrm{P}$} \\
\hline & & & & ratio & $\% \Delta$ & ratio & $\% \Delta$ & ratio & $\% \Delta$ \\
\hline control & 16.9 & 0.95 & 0.01 & 20.8 & & 3029.0 & & 145.7 & \\
\hline salt $1_{10} \mathrm{P}_{20}$ & 14.1 & 0.86 & 0.01 & 19.2 & -7 & 2602.5 & -14 & 135.3 & -7 \\
\hline salt $_{10} \mathrm{P}_{40}$ & 19.9 & 1.21 & 0.02 & 19.2 & -8 & 2859.7 & -6 & 148.8 & 2 \\
\hline salt $_{10} \mathrm{P}_{60}$ & 20.6 & 1.07 & 0.02 & 22.5 & 8 & 2561.2 & -15 & 114.0 & -22 \\
\hline salt $_{10} \mathrm{P}_{80}$ & 16.3 & 0.55 & 0.02 & 34.5 & 66 & 2561.8 & -15 & 74.3 & -49 \\
\hline salt $_{14} \mathrm{P}_{0}$ & 18.0 & 0.87 & 0.02 & 24.2 & 16 & 2666.0 & -12 & 110.2 & -24 \\
\hline salt $_{14} \mathrm{P}_{20}$ & 8.0 & 0.42 & 0.02 & 22.1 & 6 & 1375.8 & -55 & 62.2 & -57 \\
\hline salt $_{14} \mathrm{P}_{40}$ & 21.2 & 1.02 & 0.02 & 24.1 & 16 & 3042.2 & 0 & 126.1 & -13 \\
\hline salt $_{14} \mathrm{P}_{60}$ & 19.6 & 0.99 & 0.02 & 23.1 & 11 & 2733.5 & -10 & 118.3 & -19 \\
\hline salt $_{14} \mathrm{P}_{80}$ & 14.0 & 0.71 & 0.01 & 23.0 & 11 & 2479.5 & -18 & 107.6 & -26 \\
\hline salt $_{17} \mathrm{P}_{0}$ & 20.6 & 1.02 & 0.02 & 23.6 & 14 & 3218.9 & 6 & 136.4 & -6 \\
\hline salt $_{17} \mathrm{P}_{20}$ & 16.4 & 0.88 & 0.02 & 21.7 & 5 & 2501.1 & -17 & 115.1 & -21 \\
\hline salt $_{17} \mathrm{P}_{40}$ & 17.2 & 0.95 & 0.02 & 21.1 & 2 & 2310.6 & -24 & 109.5 & -25 \\
\hline salt $_{17} \mathrm{P}_{60}$ & 14.7 & 0.73 & 0.02 & 23.5 & 13 & 2506.5 & -17 & 106.8 & -27 \\
\hline salt $_{17} \mathrm{P}_{80}$ & & 0.29 & 0.02 & & & & & 39.3 & -73 \\
\hline salt $_{22} \mathrm{P}_{0}$ & 15.7 & 0.69 & 0.01 & 26.6 & 28 & 2973.2 & -2 & 111.6 & -23 \\
\hline salt $_{22} \mathrm{P}_{20}$ & 17.8 & 0.94 & 0.01 & 22.1 & 6 & 3695.3 & 22 & 167.2 & 15 \\
\hline salt $_{22} \mathrm{P}_{40}$ & 19.5 & 1.05 & 0.02 & 21.8 & 5 & 2296.5 & -24 & 105.5 & -28 \\
\hline salt $_{22} \mathrm{P}_{60}$ & 16.7 & 0.92 & 0.02 & 21.2 & 2 & 2605.9 & -14 & 123.2 & -15 \\
\hline salt $_{22} \mathrm{P}_{80}$ & 16.3 & 0.71 & 0.02 & 26.7 & 28 & 2182.2 & -28 & 81.9 & -44 \\
\hline salt $_{22} \mathrm{P}_{0}$ & 11.5 & 0.58 & 0.02 & 23.2 & 11 & 1756.5 & -42 & 75.8 & -48 \\
\hline salt $_{22} \mathrm{P}_{20}$ & 13.3 & 0.68 & 0.01 & 22.8 & 10 & 2973.9 & -2 & 130.3 & -11 \\
\hline salt $_{22} \mathrm{P}_{40}$ & 16.6 & 0.73 & 0.01 & 26.5 & 27 & 2928.5 & -3 & 110.6 & -24 \\
\hline salt $_{22} \mathrm{P}_{60}$ & & & 0.03 & 0.0 & & & & & \\
\hline salt $_{22} \mathrm{P}_{80}$ & 13.4 & 0.82 & 0.02 & 19.0 & -8 & 1537.0 & -49 & 80.7 & -45 \\
\hline
\end{tabular}

Notes: Data are not replicated $(n=1)$. The percent difference between control and treatment litter $\mathrm{C}: \mathrm{N}, \mathrm{C}: \mathrm{P}$, and $\mathrm{N}: \mathrm{P}$ molar ratios are shown as $\% \Delta$. 


\section{FIGURES}

FIG. 1. The experimental layout of response surface design. Each incubation chamber was assigned to a concentration of added phosphorus $\left(+0,20,40,60\right.$, and $\left.80 \mu \mathrm{g} \mathrm{L}^{-1}\right)$ and added salinity (freshwater: $+0,4,7,12$, and 16 ppt; brackish: $+10,14,17,22$, and 26 ppt).

FIG. 2. Surface contour plots of freshwater and brackish soil phosphatase activity measured on week 2 and 5 at different treatment concentrations of added salinity and phosphorus.

FIG. 3. Surface contour plots of freshwater and brackish soil arylsulfatase activity measured on week 2 and 5 at different treatment concentrations of added salinity and phosphorus.

FIG. 4. Surface contour plots of freshwater and brackish soil respiration rates measured on week 2 and 5 at different treatment concentrations of added salinity and phosphorus.

FIG. 5. Surface contour plots of freshwater and brackish soil microbial biomass C measured on week 2 and 5 at different treatment concentrations of added salinity and phosphorus. 
FIG. 1.
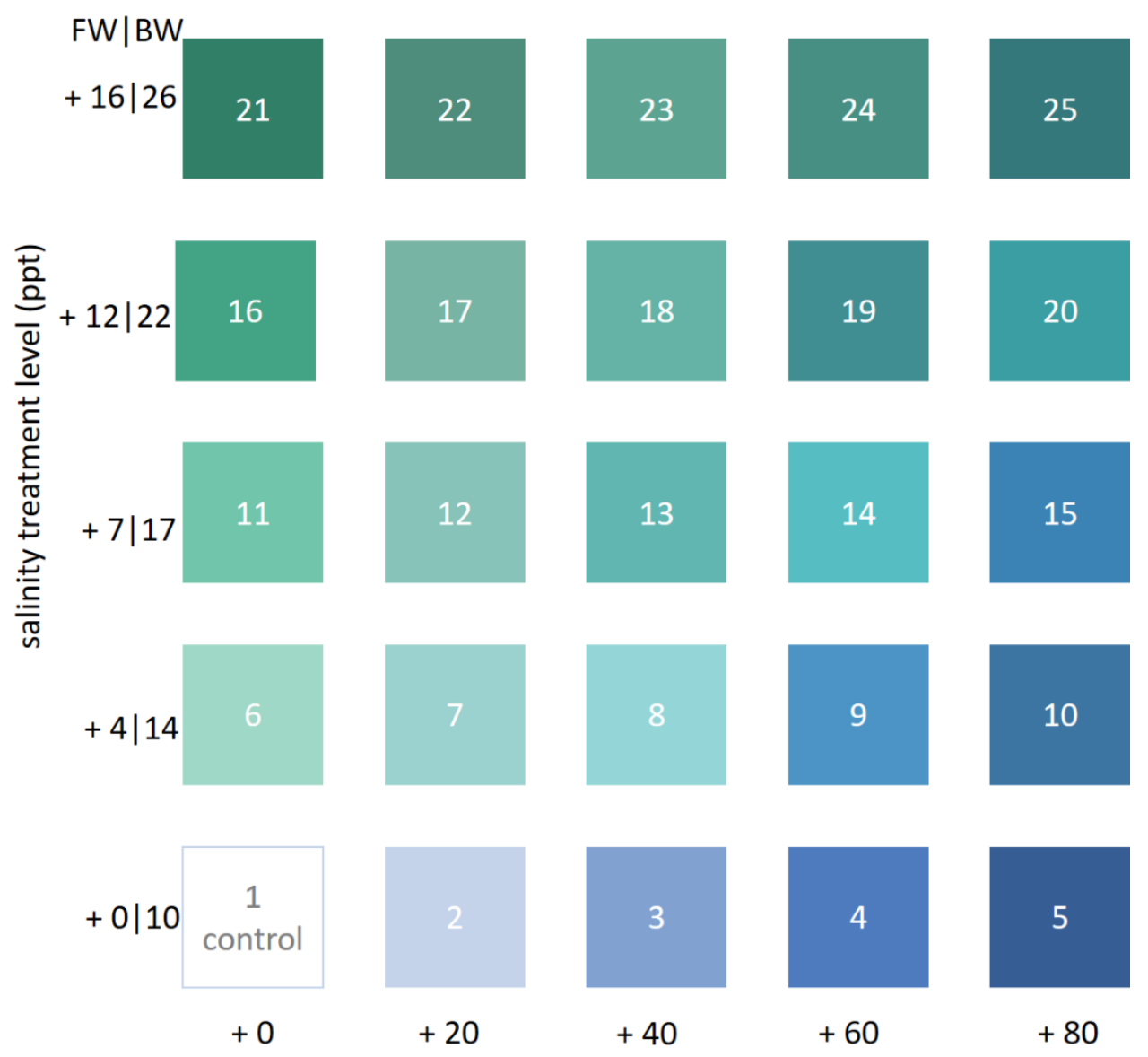

$+60$

$+80$

phosphorus treatment level $\left(\mu \mathrm{g} \mathrm{L}^{-1}\right)$ 
FIG. 2.

week 2
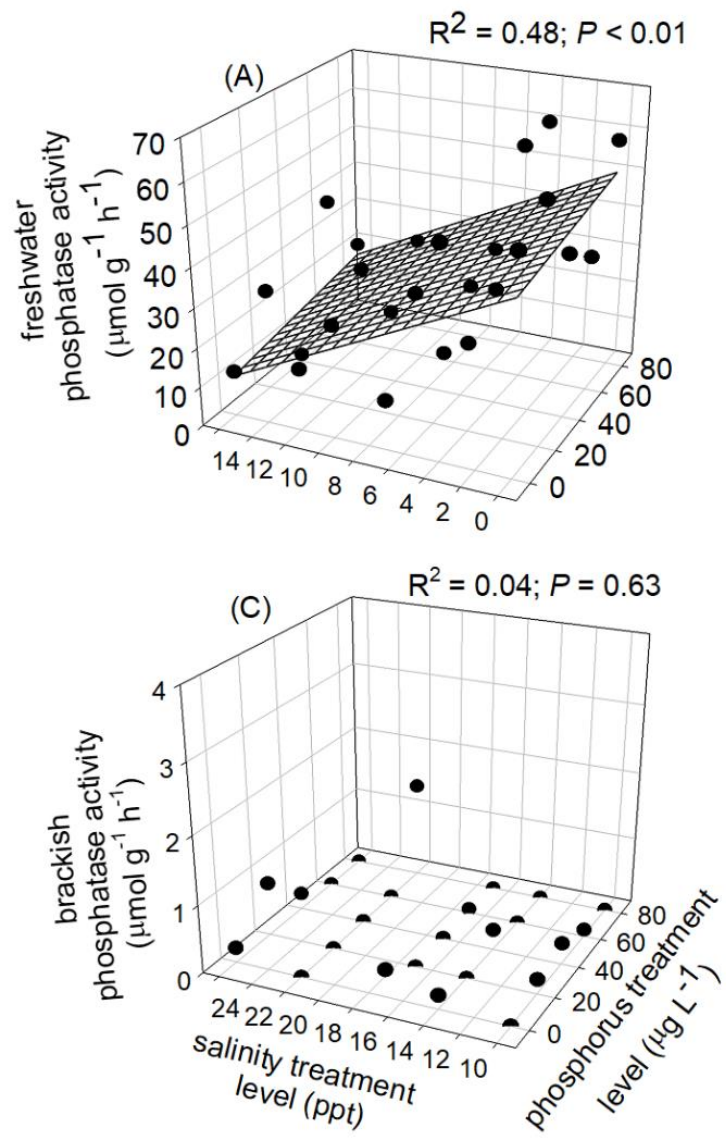

week 5
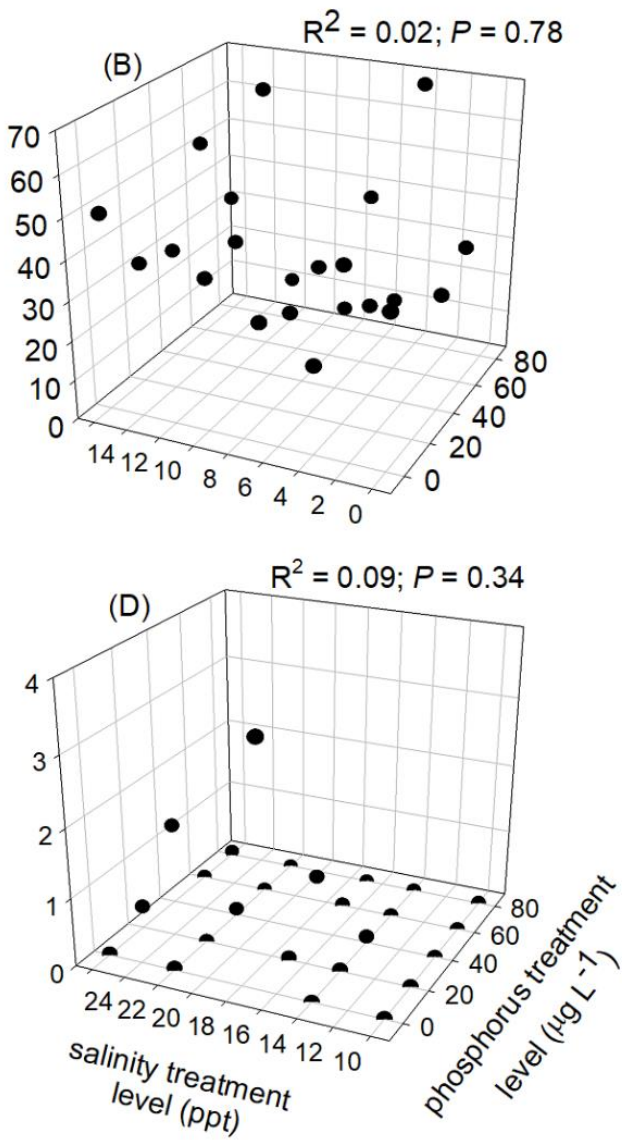
FIG. 3.
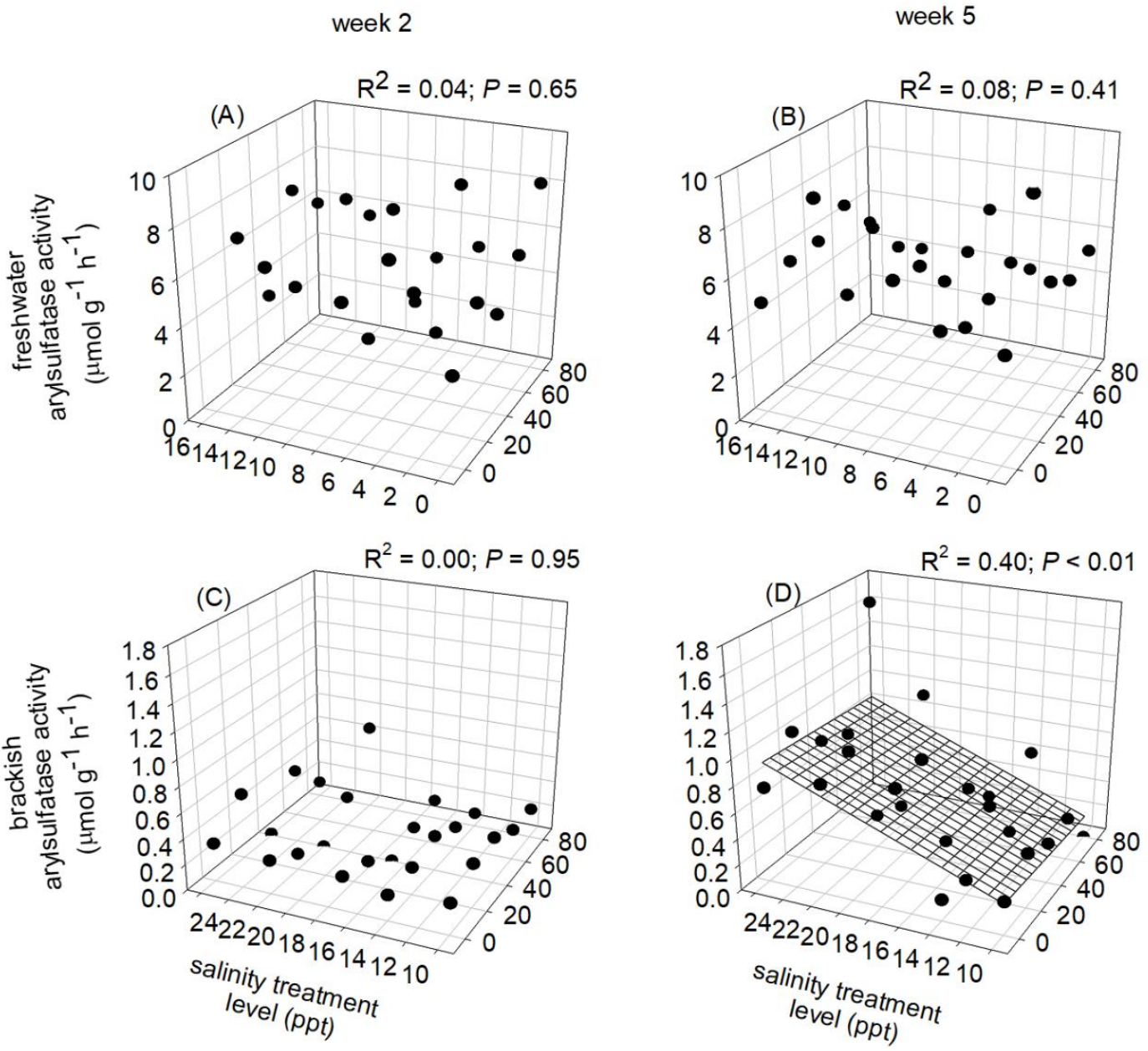
FIG. 4.

week 2
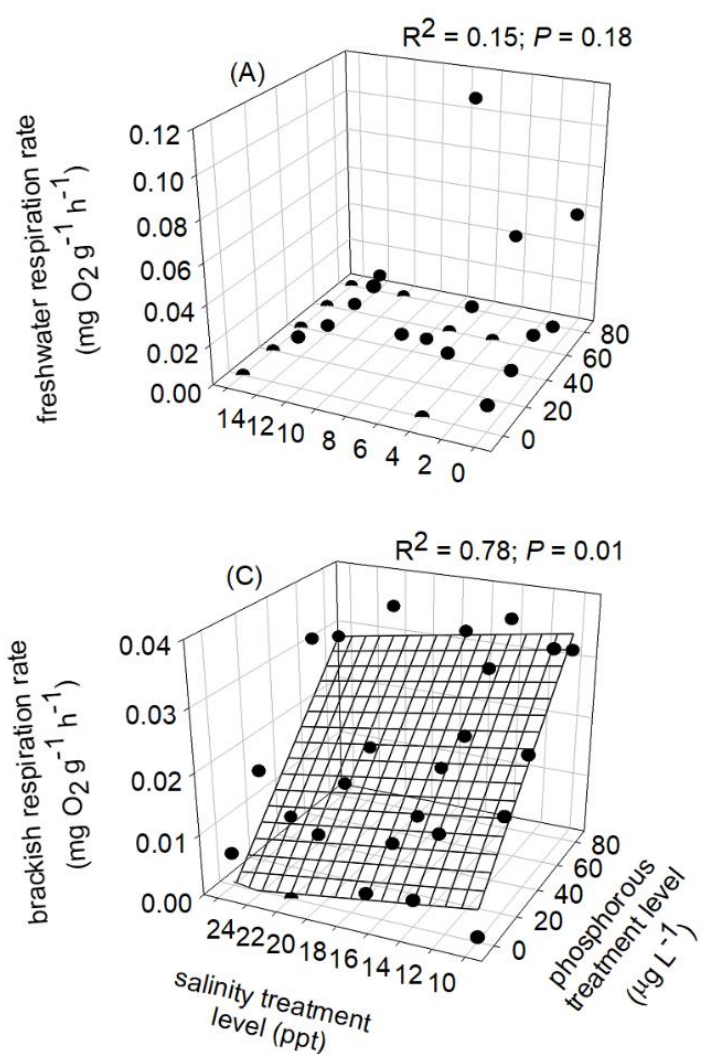

week 5
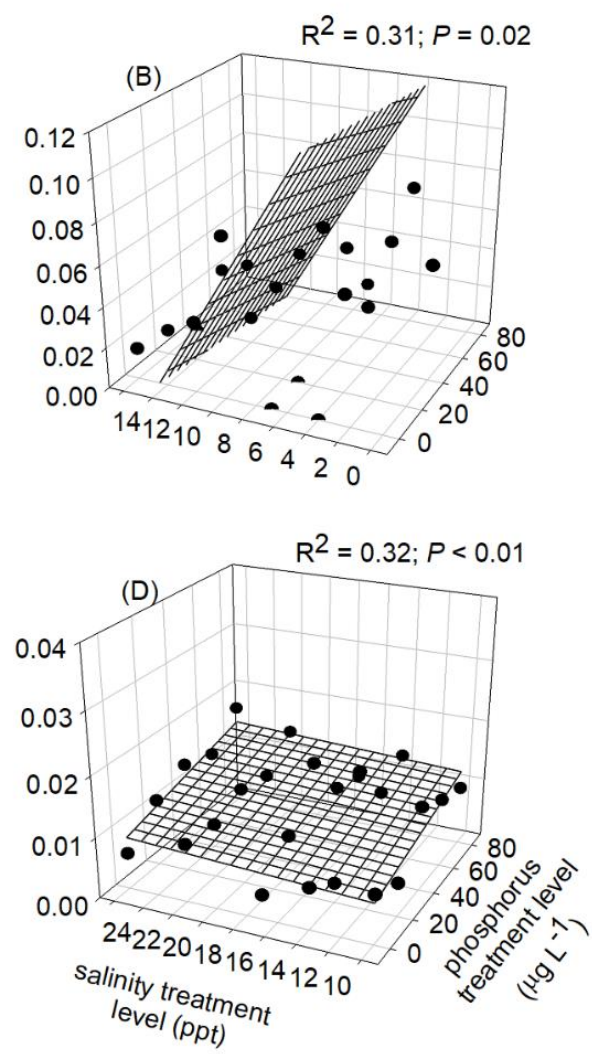
FIG. 5.
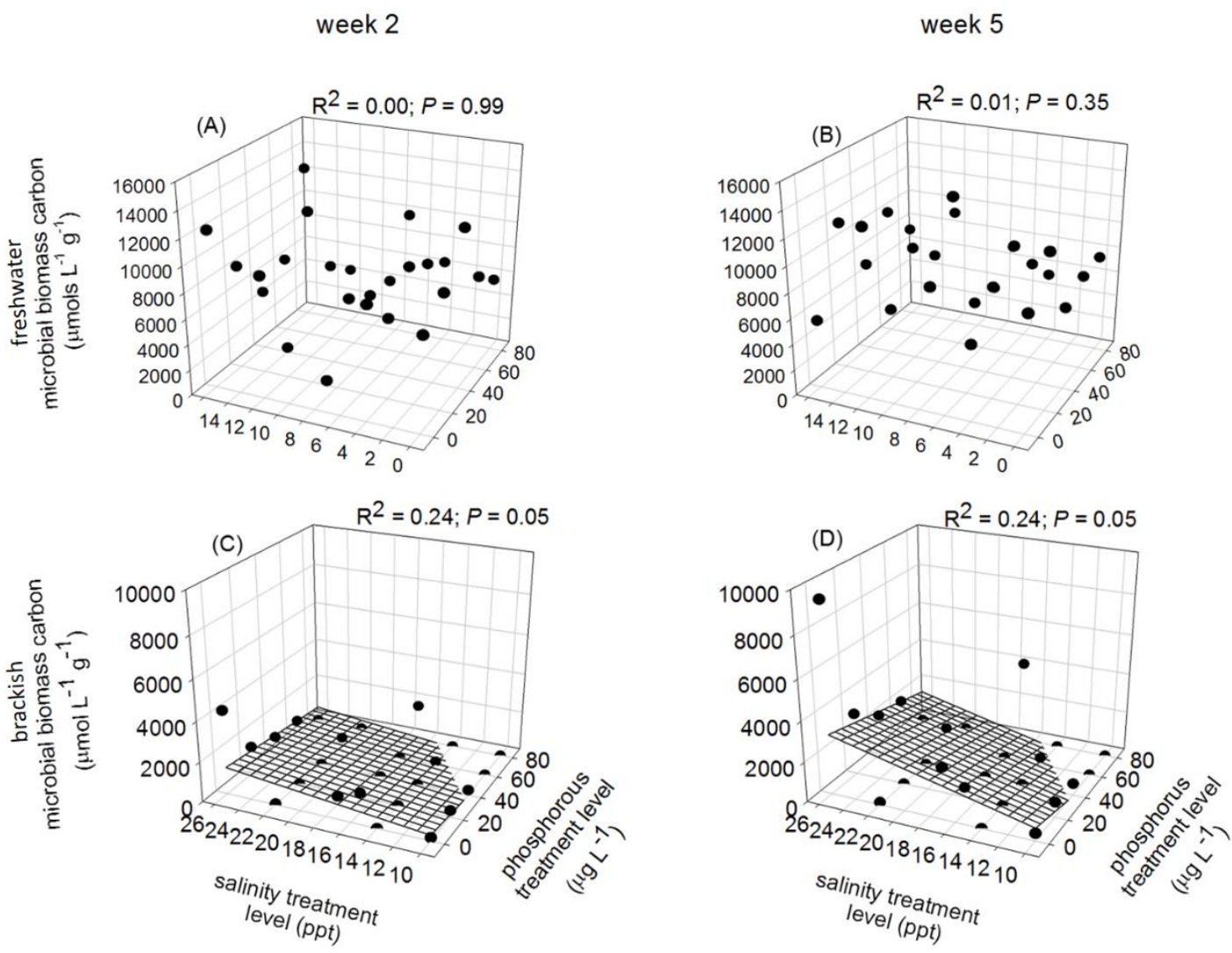


\section{SUPPLEMENTAL INFORMATION}

TABLE S1. Enzyme activities measured on initial, week 2, and week 5 soil samples. Units for extracellular enzyme activity are $\mu \mathrm{mol} \mathrm{g} \mathrm{g}^{-1} \mathrm{~h}^{-1}$ and represent the average of $n=6$ initial samples ( \pm standard error) and control $(n=1)$ samples for week 2 and 5 .

\begin{tabular}{crr}
\hline & freshwater soil & brackish soil \\
\hline initial & & \\
phosphatase & $0.15(0.13)$ & $2.76(1.24)$ \\
arylsulfatase & $5.97(1.35)$ & $2.02(0.50)$ \\
$\beta$-1,4-glucosidase & $2.99(0.66)$ & $2.81(0.36)$ \\
$\beta$-1,4-cellobiosidase & $0.56(0.10)$ & $0.53(0.06)$ \\
leucine aminopeptidase & $0.30(0.09)$ & non-detectable \\
week 2 & & 0.00 \\
phosphatase & 54.16 & 0.25 \\
arylsulfatase & 3.73 & 0.19 \\
$\beta$-1,4-glucosidase & 3.77 & 0.03 \\
$\beta$-1,4-cellobiosidase & 0.80 & 0.00 \\
leucine aminopeptidase & 3.09 & 0.01 \\
week 5 & & 0.26 \\
phosphatase & 38.87 & 0.12 \\
arylsulfatase & 4.54 & 0.00 \\
$\beta$-1,4-glucosidase & 3.85 & 0.00 \\
$\beta$ leucine aminopeptidase & 0.51 & \\
\hline
\end{tabular}




\section{CONCLUSION}

The coastal wetlands of the Florida Everglades are experiencing multiple interacting stressors and subsidies across the landscape, ranging from storm-surge induced defoliation and nutrient deposition in the coastal mangroves to saltwater intrusion induced osmotic stress and nutrient exposure in the brackish and freshwater marshes. Environmental perturbations like storm-surge, saltwater intrusion, and phosphorus $(\mathrm{P})$ enrichment are interacting to elicit changes in ecosystem biogeochemical cycling. Here, I tested how ecological disturbances affect microbially-mediated biogeochemistry within three essential ecosystems of the Florida Everglades. By coupling subsidy-stress manipulative studies across the landscape, I have determined the pathways of accelerated ecosystem changes mediated by changes in microbial function and I identified environmental conditions that may help preserve microbial function in the face of these changes.

For Chapter I, I conducted mesocosm studies in the coastal mangrove ecosystem, where storm surges cause significant perturbations that defoliate large swaths of mangroves and deposit marine sediment rich in the limiting nutrient, P (Alongi 2008). I found that mangroves can recover defoliated leaves within six weeks, carbon losses from the system are diminished by a reduction in carbon mineralization, and mangroves quickly consume available $\mathrm{P}$ from the soil and incorporate it into biomass. Phosphorus uptake by plants combined with suppression of soil $\mathrm{C}$ losses with defoliation could represent pathways towards ecosystem resilience. However, there were also potential mechanisms that inhibited mangrove resiliency: $\mathrm{P}$ addition enhanced $\mathrm{CO}_{2}$ efflux at night which may result in net losses of carbon from mangrove ecosystems. 
In Chapter II, I show that presses of salinity in freshwater marshes suppress microbial extracellular enzyme potential. Freshwater soils lost significant amounts of organic $\mathrm{C}$ to the soil porewater and surface water with increased salinity but without increasing soil respiration or microbial extracellular enzymes. Interestingly, for certain enzymes, salinity suppression was mediated with added $\mathrm{P}$, indicating that nutrient subsidies can mitigate short-term effects of stressors on nutrient acquiring enzymes. My studies revealed that the dominant pathway behind soil $\mathrm{C}$ loss in freshwater marshes was through DOC and TOC export with salinity exposure and increased litter breakdown with $\mathrm{P}$ exposure.

In Chapter III, I found that organic matter processing in both freshwater and brackish marshes is resilient to repeated monthly pulses of saltwater. Short-term breakdown of organic detritus is enhanced in brackish marshes by a single pulse of saltwater. However, the legacy of long-term of monthly pulses did not affect breakdown rates in both freshwater and brackish marshes. I identify inundation as a potential "latch" preventing microbial biogeochemical cycles from responding to pulses of saltwater in both brackish and freshwater marshes. In line with results from Chapter II, I found that C-acquiring enzymes are most susceptible to salinity suppression after long-term exposure to salinity.

In Chapter IV, after observing the difference in baseline microbial activity between freshwater and brackish soils in situ (Chapter III) and effects of single levels of salinity and P (Chapter II), I conducted a response surface experiment. I exposed both freshwater and brackish soils to gradients of increasing salinity and P. In line with my findings from Chapter III, I found that microbial activity was lower within brackish soils 
compared to freshwater soils indicating that saltwater intrusion has long-lasting legacies on microbially-mediated biogeochemical cycling. Effects of salinity dominated responses in both the freshwater and brackish soils whereas direct impacts of $\mathrm{P}$ were limited indicating that $\mathrm{P}$ concentrations need to be higher to elicit changes in soil microbial communities compared to salinity which affects these processes at lower levels. The lack of $\mathrm{P}$ accumulation in soils exposed to added $\mathrm{P}$ was also observed in Chapters I and II, where plants and algae were able to outcompete the soil compartment for $\mathrm{P}$, indicating that soil components of the Everglades may be less limited by P than autotrophic communities. Therefore, we expect microbial functioning to be more sensitive to changes in salinity rather than $\mathrm{P}$ in soils experiencing saltwater intrusion.

My findings illustrate the complexities of microbial functioning in changing environments. Microbial responses to perturbations were situational and dependent on the magnitude and duration of exposure; presses resulted in more significant effects than pulses. I also identify environmental "latches' that may prevent response to changing ecological communities. For example, microbial communities in reduced environments soils, may be unable to use excess $\mathrm{P}$ because of oxygen limitation, suggesting greater thermodynamic than a nutrient limitation in these ecosystems (Helton et al. 2015; Chambers et al. 2016).

Land-use and climate changes are altering the supply of water and nutrients to coastal wetland ecosystems (Ardón et al. 2013, Deegan et al. 2012, Weston 2011). The ability of coastal ecosystems to maintain ecological services depends upon their resilience and adaptation to perturbations. Changes in the pulsing dynamic of storm frequency, saltwater intrusion, and nutrient enrichment with a changing climate may 
destabilize coastal wetlands if these ecosystems are unable to adapt (Odum et al. 1995). It is essential to understand specific mechanisms behind ecosystem resilience to tressors and subsidies to better inform ecosystem management and keep anthropogenic impacts within a "safe operating space" (Green et al. 2017). By identifying potential tipping points following disturbance, we can better predict how climate change and anthropogenic stressors may interactively alter coastal wetland ecosystem function. My results inform our understanding of if, when, and how ecosystem-level processes are affected by changing biogeochemical conditions. Understanding the mechanisms by which interacting stressors and subsidies affect microbially-mediated ecosystem function is critical for establishing ecologically relevant recommendations for Everglades restoration. My work indicates that the circumstances of exposure to changing environmental conditions dictates the extent of microbial responses. The duration and magnitude of exposure and legacies of previous exposure determine how soil microbial function will be affected by changing environmental conditions.

\section{LITERATURE CITED}

Alongi, D.M., 2008. Mangrove forests: resilience, protection from tsunamis, and responses to global climate change. Estuarine, Coastal and Shelf Science, 76(1), pp.1-13.

Ardón, Marcelo, et al. "Drought-induced saltwater incursion leads to increased wetland nitrogen export." Global Change Biology 19.10 (2013): 2976-2985.

Chambers, L.G., Guevara, R., Boyer, J.N., Troxler, T.G. and Davis, S.E., 2016. Effects of salinity and inundation on microbial community structure and function in a mangrove peat soil. Wetlands, 36(2), pp.361-371. 
Deegan, L.A., Johnson, D.S., Warren, R.S., Peterson, B.J., Fleeger, J.W., Fagherazzi, S. and Wollheim, W.M., 2012. Coastal eutrophication as a driver of salt marsh loss. Nature, 490(7420), p.388.

Green, A.J., Alcorlo, P., Peeters, E.T., Morris, E.P., Espinar, J.L., Bravo-Utrera, M.A., Bustamante, J., Díaz-Delgado, R., Koelmans, A.A., Mateo, R. and Mooij, W.M., 2017. Creating a safe operating space for wetlands in a changing climate. Frontiers in Ecology and the Environment, 15(2), pp.99-107.

Helton, A.M., Ardón, M. and Bernhardt, E.S., 2015. Thermodynamic constraints on the utility of ecological stoichiometry for explaining global biogeochemical patterns. Ecology Letters, 18(10), pp.1049-1056.

Odum, W.E., Odum, E.P. and Odum, H.T., 1995. Nature's pulsing paradigm. Estuaries, 18(4), p.547.

Weston, N.B., Vile, M.A., Neubauer, S.C. and Velinsky, D.J., 2011. Accelerated microbial organic matter mineralization following salt-water intrusion into tidal freshwater marsh soils. Biogeochemistry, 102(1-3), pp.135-151. 
VITA

\section{SHELBY SERVAIS}

Born, Pensacola, Florida

2013

B.S., Environmental Science

Mount Saint Mary's University

Emmitsburg, Maryland

2016

M.S., Biology

Florida International University

Miami, Florida

2014-2016

President, Florida Coastal Everglades Student Group Florida Coastal Everglades LTER

Miami, Florida

2015-2018

Science Communication Fellow

Philip and Patricia Frost Science Museum

Miami, Florida

2015

Graduate Student of the Year Award

Florida Coastal Everglades LTER

Miami, Florida

2018

Dissertation Year Fellowship

Florida International University

Miami, Florida

2013-2018

Doctoral Candidate

Florida International University

Miami, Florida

\section{SELECTED PUBLICATIONS AND PRESENTATIONS}

Servais. S., et al. Effects of increased salinity on microbial processing of carbon and nutrients in brackish and freshwater wetland soils. Biology Graduate Student Symposium, Biscayne Bay, Florida, 2018

Servais. S., et al. Effects of pulsed salinity exposure on microbial processing in wetland soils. Greater Everglades Ecosystem Restoration, Coral Springs Florida, 2017 
Servais. S., et al. Experimental addition of salt alters microbial enzyme activities and root decomposition in Everglades wetland soils. Biology Graduate Student Symposium, Biscayne Bay, Florida, 2017

Servais. S., et al. Effects of saltwater intrusion on microbial processing of carbon and nutrients. Ecological Society of America Annual Meeting, Ft. Lauderdale, Florida, 2016

Servais. S., et al. Subsidy-stress effects of saltwater intrusion on microbial processing of carbon and nutrients. Biology Graduate Student Symposium, Biscayne Bay, Florida, 2016

Servais. S., et al. Understanding changes in microbial enzyme potential with exposure to salinity. Ecological Society of America Annual Meeting, Baltimore, Maryland, 2015

Servais. S., et al. Effects of increased salinity and inundation on microbial processing of carbon and nutrients. Greater Everglades Ecosystem Restoration, Coral Springs, Florida, 2015 